Leticia de Oliveira Neves

\title{
ARQUITETURA BIOCLIMÁTICA E A OBRA DE SEVERIANO PORTO: ESTRATÉGIAS DE VENTILAÇÃO NATURAL
}

Dissertação apresentada à Escola de Engenharia de São Carlos da Universidade de São Paulo, como parte dos requisitos para a obtenção do título de Mestre em Arquitetura e Urbanismo Área de concentração: Arquitetura, Urbanismo e Tecnologia Orientador: Profa. Dra. Rosana Maria Caram de Assis 
AUTORIZO A REPRODUÇÃO E DIVULGAÇÃO TOTAL OU PARCIAL DESTE TRABALHO, POR QUALQUER MEIO CONVENCIONAL OU ELETRÔNICO, PARA FINS DE ESTUDO E PESQUISA, DESDE QUE CITADA A FONTE.

Ficha catalográfica preparada pela Seção de Tratamento da Informação do Serviço de Biblioteca - EESC/USP

\begin{tabular}{|c|c|}
\hline \multirow[t]{3}{*}{ N518a } & $\begin{array}{l}\text { Neves, Leticia de Oliveira } \\
\text { Arquitetura bioclimática e a obra de Severiano Porto } \\
\text { Estratégias de ventilação natural / Leticia de Oliveira } \\
\text { Neves; orientador Rosana Maria Caram de Assis. -- São } \\
\text { Carlos, 2006. }\end{array}$ \\
\hline & $\begin{array}{l}\text { Dissertação (Mestrado-Programa de Pós-Graduação em } \\
\text { Arquitetura e Urbanismo. Área de Concentração: } \\
\text { Arquitetura, Urbanismo e Tecnologia) -- Escola de } \\
\text { Engenharia de São Carlos da Universidade de São Paulo, } \\
2006 \text {. }\end{array}$ \\
\hline & $\begin{array}{l}\text { 1. Ventilação natural. 2. Arquitetura climática. } \\
\text { 3. Clima quente e úmido. 4. Severiano Porto. I. Título. }\end{array}$ \\
\hline
\end{tabular}


Aos meus pais, pelo carinho e apoio em todos os momentos de minha vida, e por tudo que eles representam para mim. 


\section{AGRADECIMENTOS}

À profa. Rosana Caram, pela orientação, incentivo e confiança depositada nesta pesquisa.

Ao prof. Maurício Roriz, pela disposição em me auxiliar e pela contribuição no desenvolvimento desta pesquisa, através de críticas e comentários.

À profa. Anésia Frota, pelas contribuições dadas na banca do exame de qualificação.

Aos meus pais e às minhas irmãs, por todo 0 amor e carinho.

Aos meus amigos, minha segunda família, por estarem sempre presentes e compartilharem comigo todo o período de minha formação, companhia fundamental à minha vida.

À profa. Elizabete Martins e Tatiana Barreto, do Núcleo de Pesquisa e Documentação da Universidade Federal do Rio de Janeiro, pelo auxílio na consulta ao acervo do arquiteto Severiano Porto para obtenção de dados sobre suas obras.

Ao prof. Nelson Kuwahara, da Universidade Federal do Amazonas; à Auxiliadora Tupinambá e Roberto de Almeida Morais, da Superintendência da Zona Franca de Manaus; à mãe Lúcia, das Aldeias Infantis soS Brasil, pelo auxílio no desenvolvimento da pesquisa de campo.

Ao prof. Paulo Greco, pela ajuda nas tentativas de simulações.

Ao Severiano Porto, pelas informações e materiais disponibilizados, e pela atenção dedicada à pesquisa durante a entrevista.

E finalmente à FAPESP, pela bolsa de mestrado concedida e pelo apoio financeiro obtido através do projeto de auxílio à pesquisa intitulado "Arquitetura bioclimática e a obra de Severiano Porto", essencial para a realização da pesquisa de campo. 


\section{RESUMO}

NEVES. L. O. (2006) Arquitetura bioclimática e a obra de Severiano Porto: estratégias de ventilação natural. Dissertação (Mestrado) - Escola de Engenharia de São Carlos, Universidade de São Paulo, São Carlos, 2006.

O emprego da arquitetura bioclimática conduz à minimização dos impactos de uma intervenção no meio e à obtenção de uma relação mais harmoniosa entre paisagem e construção. Esta pesquisa evidencia o potencial da ventilação natural como recurso para resfriamento em climas quentes e úmidos, contribuindo para o aprofundamento no estudo de estratégias de projeto que auxiliem na maior integração do edifício com o clima e contexto locais. Analisa as estratégias de ventilação natural adotadas pelo arquiteto Severiano Porto em suas obras, dada a importância deste tipo de solução para obtenção de conforto térmico em clima tropical quente e úmido. Realiza-se por meio de discussão e análise de três obras do arquiteto, localizadas na cidade de Manaus-AM, e as diferentes soluções propostas, quanto à sua adeqüabilidade e eficiência. A análise se divide em duas etapas: primeiramente a análise qualitativa e descritiva, baseada em leitura de projeto, onde é verificada a incorporação de conceitos bioclimáticos nas edificações e são identificadas as soluções de ventilação natural propostas, através do desenho e caracterização dos sistemas encontrados; seguida da análise quantitativa, realizada através de pesquisa de campo e medições das variáveis ambientais temperatura, umidade relativa e velocidade do ar. A análise dos resultados foi realizada com base nos métodos de Mahoney e ASHRAE Standard 55-2004, assim como em alguns parâmetros obtidos em literatura especializada. Pôde-se identificar as estratégias de ventilação natural utilizadas, tanto cruzada como de efeito chaminé, avaliando-se detalhadamente seu desempenho nos três edifícios. A pesquisa contribui no aperfeiçoamento das soluções projetuais de ventilação natural, visando valorizar 0 uso de estratégias de energia passiva na arquitetura. Evidencia também a contribuição de Porto no desenvolvimento de uma arquitetura atenta a princípios bioclimáticos.

Palavras-chave: Ventilação natural; Arquitetura bioclimática; Clima quente e úmido; Severiano Porto. 


\section{ABSTRACT}

NEVES. L. O. (2006) Bioclimatic architecture and Severiano Porto's work: natural ventilation strategies. Dissertação (Mestrado) - Escola de Engenharia de São Carlos, Universidade de São Paulo, São Carlos, 2006.

Bioclimatic architecture consists in minimizing the impacts of an intervention on the environment and obtaining a close relationship between building and nature. This research emphasizes the importance of natural ventilation as a cooling resource for hot and humid climates, contributing for the study of project strategies that adjust to local context and environment. Analyses the natural ventilation strategies used by the architect Severiano Porto in his buildings, since it is an important kind of solution to obtain thermal comfort in tropical hot and humid weather. It presents the discussion and analysis of three of his main works, placed in the city of Manaus, and the efficiency of the different solutions proposed. The analysis is divided in two steps: first a qualitative and descriptive analysis, based on project examination, where the incorporation of bioclimatic concepts in the buildings is verified and the natural ventilation solutions are identified; followed by a quantitative analysis, based on field studies and measurement of the variables temperature, humidity and air velocity. The result analysis was based on the Mahoney and ASHRAE Standard 55-2004 methods, and data obtained in specialized literature. Natural ventilation strategies could be identified, either cross as stack, allowing a detailed evaluation of performance of the three buildings. The research contributes on the improvement of the architectonic solutions on natural ventilation, on the purpose of valuing the use of passive energy strategies in architecture. Valorizes also Porto's contribution to the development of an architecture that is attentive to bioclimatic principles.

Keywords: Natural ventilation; Bioclimatic architecture; Hot and humid weather; Severiano Porto. 


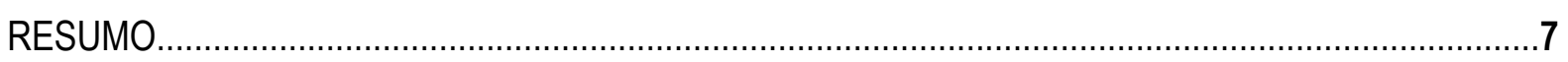

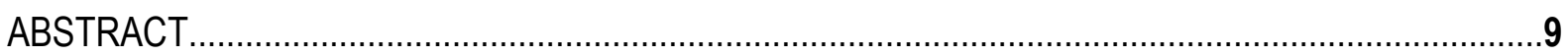

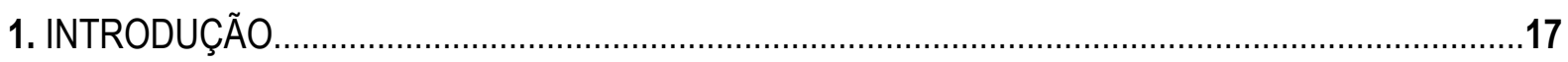

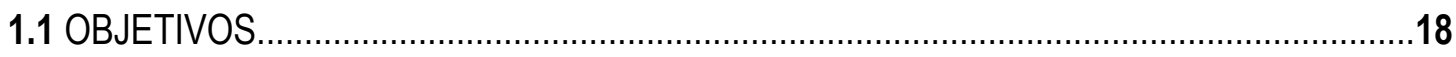

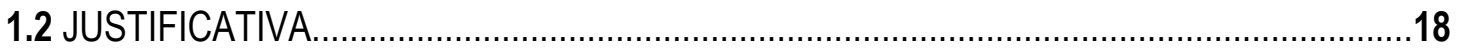

2. ARQUITETURA BIOCLIMÁTICA: REVISÃO BIBLIOGRÁFICA ...................................................21

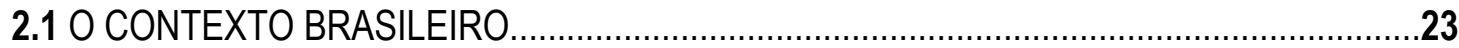

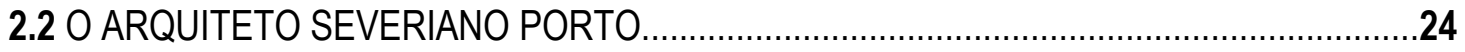

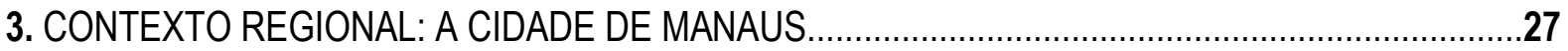

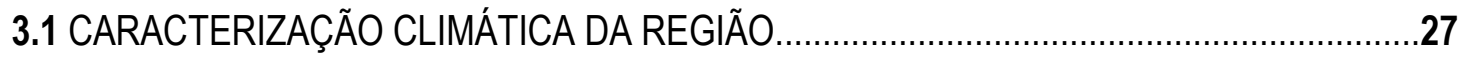

4. CLIMA QUENTE E ÚMIDO: CONFORTO TÉRMICO

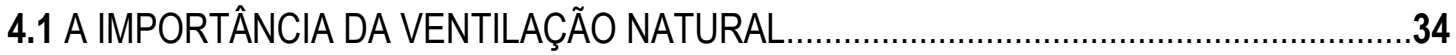

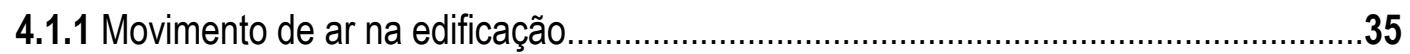

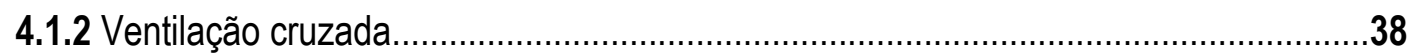

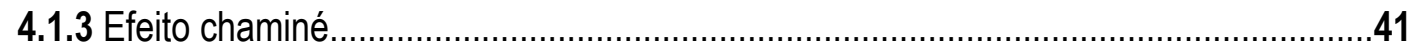

4.1.4 Aberturas.

5. O ARQUITETO SEVERIANO PORTO

5.1 FORMANDO E AFIRMANDO UMA POSTURA ARQUITETÔNICA ..................................45

5.2 UM POUCO DE SUA TRAJETÓRIA...........................................................................

5.3 PRODUÇÃO ARQUITETÔNICA NA CIDADE DE MANAUS-AM.......................................53

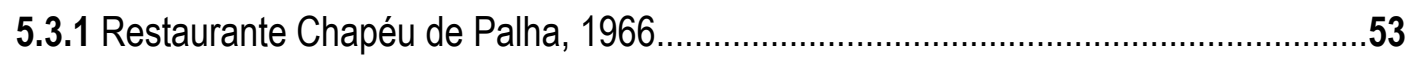

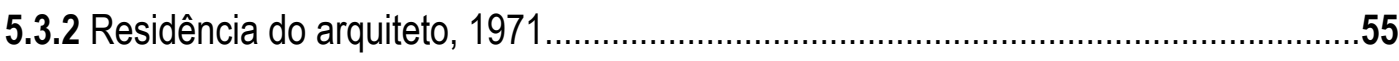

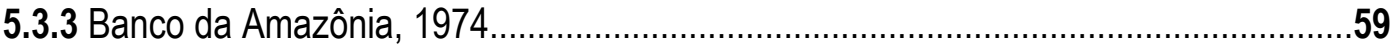

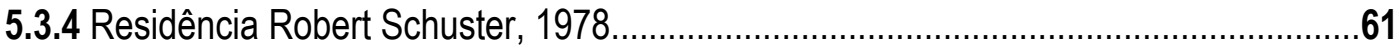


5.3.5 Ambulatório médico do IPASEA, 1979 .63

5.3.6 Centro de Proteção Ambiental de Balbina, Presidente Figueiredo, 1983-88. .65

5.4 IMPORTÂNCIA DO ARQUITETO NO CONTEXTO DE ESTUDO ….....................................

6. MATERIAIS E MÉTODOS 69

6.1 LEVANTAMENTO DE DADOS. 69

6.2 ANÁLISE QUALITATIVA E DESCRITIVA...............................................................

6.3 ANÁLISE QUANTITATIVA ......................................................................................

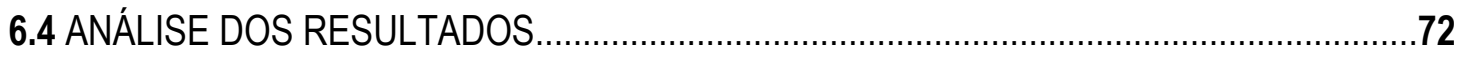

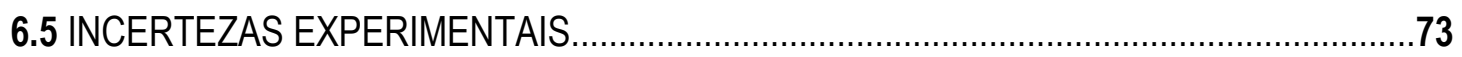

7. AS TRÊS OBRAS SELECIONADAS E OS MÉTODOS DE ANÁLISE ..........................................75

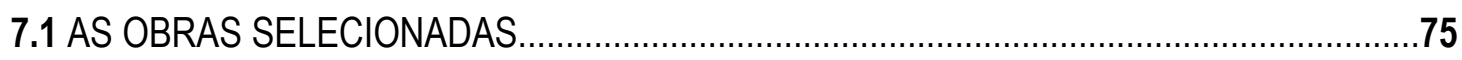

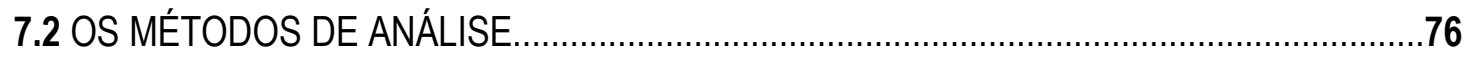

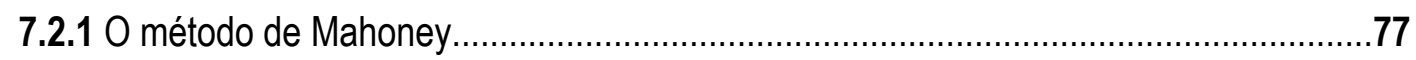

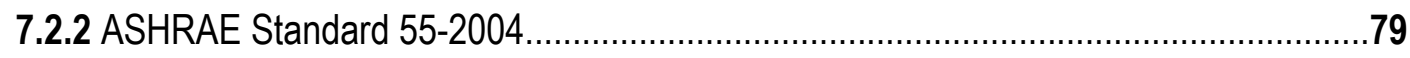

7.2.3 Os parâmetros para análise de ventilação natural.................................................81

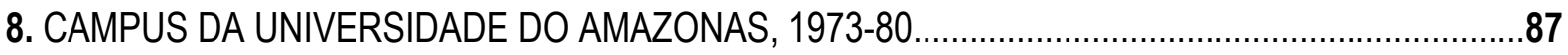

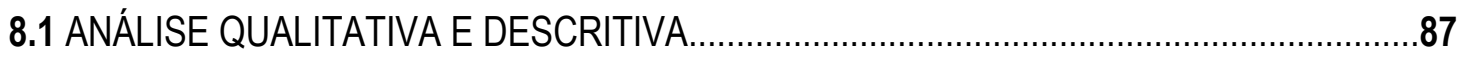

8.1.1 Área de inserção e implantação........................................................................8

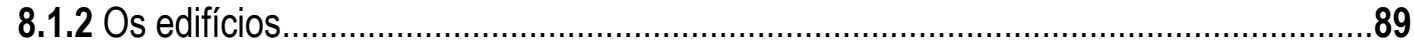

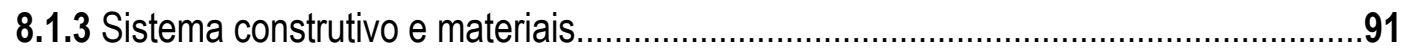

8.1.4 Estratégias bioclimáticas e conforto ambiental.......................................................92

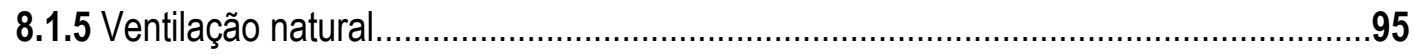

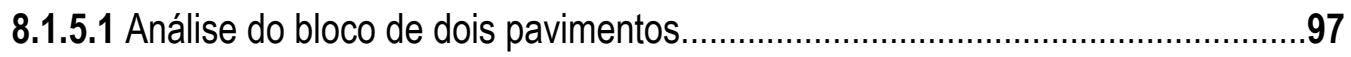

8.1.5.2 Análise do bloco de um pavimento: salas de aula.........................................99

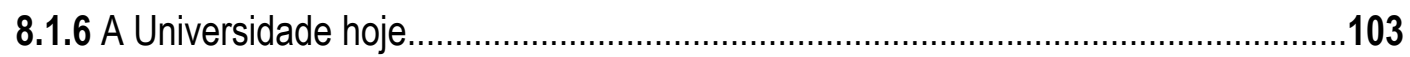

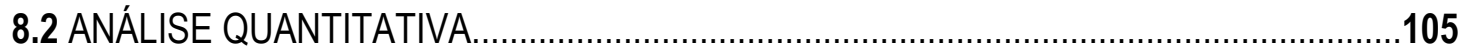


8.2.1 Caracterização dos ambientes escolhidos para análise 106

8.2.1.1 Sala 207 107

8.2.1.2 Sala 204 108

8.2.2 Dados obtidos para temperatura e umidade. 108

8.2.3 Dados obtidos para velocidade do ar. 112

8.3 ANÁLISE DOS RESULTADOS. 116

8.3.1 Análise de desempenho térmico: temperatura e umidade... 116

8.3.2 Análise de ventilação natural 119

8.3.3 Considerações finais. 122

9. SEDE DA SUPERINTENDÊNCIA DA ZONA FRANCA DE MANAUS (SUFRAMA), 1973. 125

9.1 ANÁLISE QUALITATIVA E DESCRITIVA.. 125

9.1.1 Área de inserção e implantação. 126

9.1.2 0 edifício. 127

9.1.3 Sistema construtivo e materiais. 127

9.1.4 Estratégias bioclimáticas e conforto ambiental: ventilação natural. 130

9.1.5 A Suframa hoje. 135

9.2 ANÁLISE QUANTITATIVA. 136

9.2.1 Caracterização dos ambientes escolhidos para análise. 137

9.2.1.1 Entrada principal do edifício 137

9.2.1.2 Área de circulação que interliga o edifício principal ao anexo. 139

9.2.2 Dados obtidos para temperatura e umidade. 140

9.2.3 Dados obtidos para velocidade do ar. 144

9.3 ANÁLISE DOS RESULTADOS. 146

9.3.1 Análise de desempenho térmico: temperatura e umidade.. 147

9.3.2 Análise de ventilação natural. 149

9.3.3 Considerações finais. 
10. ALDEIAS INFANTIS SOS BRASIL, 1994

10.1 ANÁLISE QUALITATIVA E DESCRITIVA...............................................................153

10.1.1 Área de inserção e implantação ......................................................................154

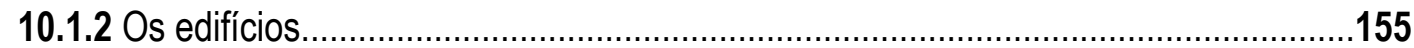

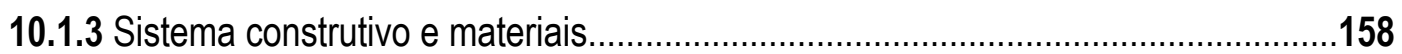

10.1.4 Estratégias bioclimáticas e conforto ambiental..................................................158

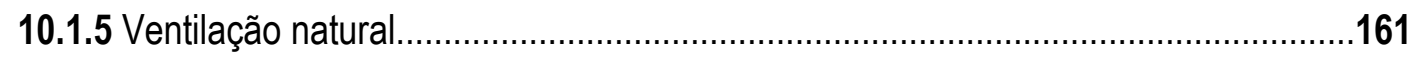

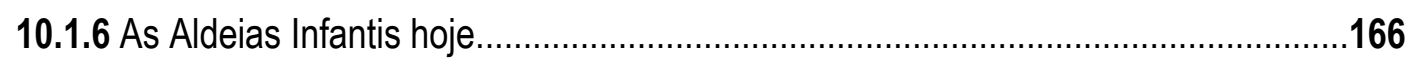

10.2 ANÁLISE QUANTITATIVA.................................................................................

10.2.1 Caracterização dos ambientes escolhidos para análise......................................169

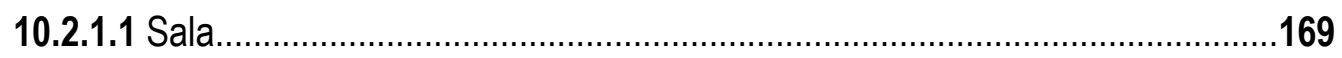

10.2.1.2 Quarto das crianças.........................................................................171

10.2.2 Dados obtidos para temperatura e umidade .....................................................172

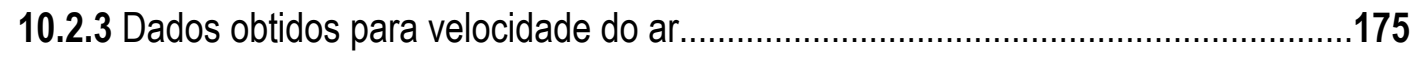

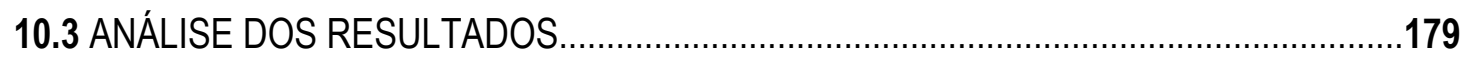

10.3.1 Análise de desempenho térmico: temperatura e umidade...................................179

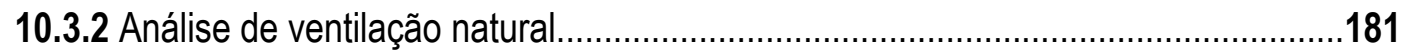

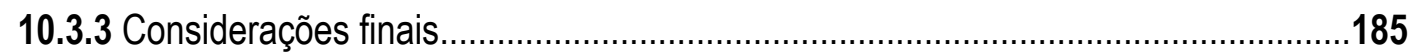

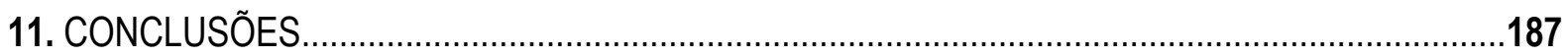

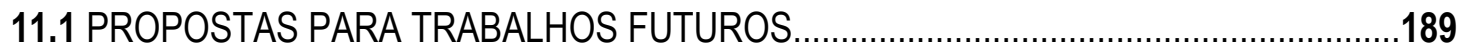

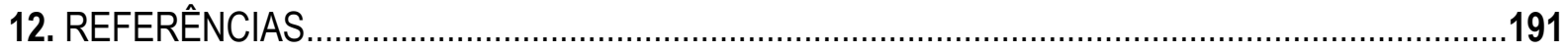

13. ANEXOS

13.1 TRANSCRIÇÃO DA CONVERSA COM SEVERIANO PORTO ........................................201

13.2 ARQUIVO DE IMAGENS COLETADAS NO ACERVO DE SEVERIANO PORTO............216

13.2.1 Aldeias Infantis SOS Brasil, 1994...................................................................216

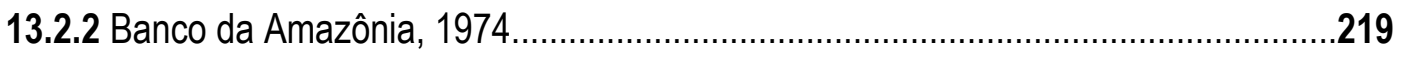


13.2.3 Centro de Proteção Ambiental de Balbina - ELETRONORTE, 1985 .220

13.2.4 Residência Robert Schuster, 1978 221

13.2.5 Superintendência da Zona Franca de Manaus (SUFRAMA), 1973. 222

13.2.6 Universidade do Amazonas, 1973-80 223

13.2.7 Residência do arquiteto, 1971 226

13.2.8 Residência Alexandre Ale dos Santos, 1982. 226

13.2.9 Hotel Silves - Pousada de Caça e Pesca, 1979. .227

13.2.10 Edifício Aracoara, 1987 .228

13.2.11 Ipasea ambulatórios, 1979 228

13.2.12 Chapéu de Palha, 1966. .229

13.3 DADOS CLIMATOLÓGICOS DO AERÓDROMO DE EDUARDO GOMES-AM. 230 


\section{INTRODUÇÃO}

O conceito de arquitetura bioclimática engloba uma série de valores relacionados à redução de impactos ambientais, conservação de energia e obtenção de conforto ambiental no projeto construído. Seu estudo e aplicação visam maior inserção da arquitetura no clima e contexto locais. Importantes estratégias projetuais relacionadas à questão consistem no aproveitamento dos recursos naturais e condicionantes do clima local para melhor integrar o edifício ao entorno e na obtenção de conforto através do uso de sistemas passivos de condicionamento. Severiano Mário Porto foi o arquiteto pioneiro a atuar na região amazônica abordando estas premissas em suas obras e divulgando novas idéias de tratamento dos espaços de acordo com o clima.

$\mathrm{O}$ arquiteto, formado no Rio de Janeiro, mudou-se para a cidade de Manaus-AM na segunda metade da década de 1960. A partir daí, passou a absorver, valorizar e transmitir para sua produção aspectos importantes da arquitetura regional, numa época em que era freqüente a reprodução acrítica de modelos da arquitetura moderna. Suas edificações são citadas na literatura corrente como exemplos de aplicação de soluções eficientes para o clima quente e úmido da região. Preocupações com natureza e clima são recorrentes nas obras do arquiteto, que se destaca pela percepção da necessidade de adaptação da construção ao meio e pela aplicação de soluções pertinentes de conforto em suas obras. Porto teve coragem de fugir dos padrões da época, impostos pelos grandes centros financeiros do país e do mundo, e propor algo diferente. Isto merece um crédito imenso, que o arquiteto foi conquistando na medida em que sua produção foi ganhando reconhecimento internacional.

Em vista disso, esta pesquisa insere-se na crítica arquitetônica contemporânea sobre o assunto, ao examinar estratégias projetuais que busquem maior eficiência energética e melhor relacionamento do ambiente construído com o meio. Possui como tema central a avaliação do potencial de ventilação natural como recurso para obtenção de conforto térmico em clima quente e úmido, contribuindo para aprofundar e difundir tais estudos para o clima tropical brasileiro. De acordo com Bittencourt (1995), faltam estudos sobre ventilação natural para regiões quentes e úmidas, e a literatura existente é em sua maior parte escassa e ultrapassada. No levantamento bibliográfico empreendido, a maioria das publicações encontradas é internacional. 


\subsection{OBJETIVOS}

O objetivo geral desta dissertação é evidenciar as estratégias de ventilação natural propostas por Severiano Porto em obras localizadas na Amazônia, mais especificamente na cidade de Manaus-AM, através da identificação, descrição de funcionamento e análise de desempenho das soluções encontradas. Esta análise é realizada à luz de uma discussão mais ampla, abordando conceitos bioclimáticos, relacionados à busca de adequação ao contexto e clima locais; aos materiais de construção utilizados; às soluções empregadas para obtenção de conforto térmico, como implantação, forma da edificação e dispositivos para controle da radiação solar; entre outros.

\subsection{JUSTIFICATIVA}

Estratégias de ventilação natural não são utilizadas apropriadamente em grande parte das construções da região de estudo, o que leva a um maior dispêndio de energia, devido ao uso excessivo de aparelhos de refrigeração artificial. Ao realizar uma pesquisa, em âmbito nacional, sobre posse de eletrodomésticos e hábitos de consumo no setor residencial, o Programa Nacional de Conservação de Energia Elétrica/ Eletrobrás (1989) mostrou que a porcentagem de consumidores que possuem ar condicionado em Manaus é quatro vezes maior do que em outros municípios do restante do país: o índice de posse é de $43 \%$. A pesquisa ainda revela que a potência média dos aparelhos é da ordem de $1.328 \mathrm{~W}$ e o tempo médio de uso de 7,10 horas por dia. No caso do ventilador, o índice de posse na cidade é de 1,73 aparelhos por domicílio, um número bastante significativo. A potência média dos aparelhos é de 92,5 W e o tempo médio de uso diário de 7,24 horas.

Isto evidencia o fato de que, em clima quente e úmido, soluções relacionadas à ventilação natural devem estar presentes e bem solucionadas na concepção do edifício para que se consiga um ambiente termicamente confortável. É neste contexto que se justifica a importância da pesquisa sobre ventilação natural em clima quente e úmido, foco de estudo deste trabalho, pois é um meio eficiente de evitar ou reduzir o uso de sistemas mecânicos de climatização, em busca de uma arquitetura melhor inserida no local e de maior eficiência energética. É um recurso de extrema importância para o clima, e cuidadosamente trabalhado nos edifícios projetados por Severiano Porto, através de soluções simples e criativas.

O plano de trabalho proposto é organizado em quatro etapas: revisão bibliográfica, análise qualitativa e 
descritiva, análise quantitativa e análise dos resultados. Os capítulos dois a cinco são dedicados à revisão bibliográfica para introdução ao tema, e apresentam uma discussão atualizada sobre arquitetura bioclimática, ventilação natural em clima quente e úmido, o arquiteto Severiano Porto e sua produção na Amazônia. Através destes dados foi possível selecionar três obras construídas de Porto, para uma análise mais detalhada. Os capítulos seis e sete apresentam os materiais e métodos utilizados para o desenvolvimento da pesquisa e as três obras escolhidas. Na seqüência (capítulos sete a nove), há a análise de cada obra em separado, onde as estratégias de ventilação natural adotadas são analisadas de forma minuciosa, sob os aspectos qualitativo e quantitativo, além de um estudo mais amplo sobre as soluções arquitetônicas apresentadas para adequação ao clima. 


\section{ARQUITETURA BIOCLIMÁTICA: REVISÃO BIBLIOGRÁFICA}

O processo lógico de concepção arquitetônica consiste em trabalhar em harmonia com o que a natureza oferece, adaptando o máximo possível os edifícios ao clima em que estão inseridos. A correspondência entre características arquitetônicas e determinadas zonas climáticas é o princípio fundamental da chamada Arquitetura Bioclimática, que procura minimizar os impactos resultantes de uma intervenção no meio e obter uma relação harmônica entre a paisagem e a construção.

Embora este conceito possa remontar a manifestações vernaculares - construções espontâneas baseadas em respostas intuitivas ao meio e ao clima - a expressão "projeto bioclimático" foi criada somente na década de 1960, pelos irmãos Olgyay, procurando expressar a arquitetura que busca satisfazer as exigências de conforto através de técnicas e materiais disponíveis, de acordo com as condições climáticas do lugar.

Este princípio retornou ao debate arquitetônico com maior força nos anos 1970, quando houve um início de conscientização dos limites dos recursos energéticos do planeta, devido a crises sofridas neste setor, que resultou no reconhecimento da necessidade de preservação ambiental: "Después de la reciente crisis energética, se advierte un nuevo interés por las técnicas que permiten economizar energía y, en particular, por las técnicas naturales." (CAMOUS; WATSON, 1986) A partir disso, constata-se uma maior preocupação com a questão da produção e conservação de energia, e discussões sobre os impactos ambientais causados pela construção civil se intensificam.

Assim, a arquitetura bioclimática reapareceu como uma forma de produzir uma arquitetura adequadamente inserida no clima e contexto sócio-cultural locais, em harmonia com a topografia e 0 entorno, que se aproveita dos materiais disponíveis e dos recursos naturais da região, é atenta ao conforto térmico, acústico, luminoso e procura reduzir o máximo possível a necessidade de sistemas mecânicos para isto. Corbella e Yannas a definem como uma "Arquitetura preocupada na sua integração com o clima local, visando à habitação centrada sobre o conforto ambiental do ser humano e sua repercussão no planeta." (CORBELLA; YANNAS, 2003)

O conceito, relativamente recente, passou a ser incorporado e discutido na literatura especializada, e está fortemente relacionado à produção de espaços com alta eficiência energética. Autores frequentemente referem-se ao assunto como meio de economia de energia. Para Serra (1999), podem ser obtidos baixos consumos energéticos na edificação pela sábia utilização do clima natural. 0 autor trata a arquitetura bioclimática como aquela que se aproveita da existência dos agentes ambientais 
naturais para seu melhor funcionamento.

Para Adam (2001), a arquitetura bioclimática manifesta-se pela investigação das relações entre os seres humanos e as características climáticas de um local - que devem ser harmônicas - com 0 objetivo de minimizar a quantidade de energia consumida. Quanto à questão energética, 0 autor afirma que o eco-edifício incorpora a crise mundial de energia como uma de suas premissas, ou seja, é uma resposta recente à perda da naturalidade de edificar em harmonia com o entorno.

Costa (1982) refere-se ao termo como o tipo de construção mais coerente com a natureza do lugar. Para ele, o uso de técnicas construtivas simples, mas racionais, que visem ao aproveitamento das condições favoráveis da natureza para o condicionamento ambiental, resulta, no mínimo, em uma melhoria substancial no conforto térmico interno de uma edificação. Mascaró (1991) afirma que o exercício da hoje chamada arquitetura bioclimática permite reconciliar 'forma, matéria e energia', assuntos antes tratados separadamente.

O desenho da edificação segundo princípios bioclimáticos, portanto, deve ocorrer em equilíbrio com 0 entorno imediato, levar em conta o microclima e seus recursos naturais - 0 sol, a temperatura, as correntes de ar, a vegetação - visando uma maior aproximação às condições ótimas de habitabilidade. Ao mesmo tempo, deve procurar utilizar o máximo possível soluções passivas para ganhos ou perdas de calor com o meio, evitando ao máximo a necessidade de sistemas mecânicos para transmissão energética. Deve-se procurar, enfim, o controle ambiental natural, tanto na envoltória como no interior do edifício, para amenizar os efeitos climáticos sobre o ambiente e os usuários.

Es tarea del arquitecto la utilización máxima de todos los medios naturales para producir una vivienda lo más sana y agradable posible, al mismo tiempo deberá buscar el ahorro en los costes, reduciendo al mínimo la necesidad de ayudas mecánicas para el control climático. (OLGYAY, 1998)

A concepção bioclimática visa o máximo proveito dos fenômenos naturais em benefício de um maior conforto ambiental no interior do edifício, através da adoção de elementos adequados às características regionais, condizentes às exigências de um respectivo clima. É a arquitetura preocupada com o bem estar do usuário integrada às preocupações ambientais. Como afirma Olgyay (1998): "Aquellas estructuras que, en un entorno determinado, reducen tensiones innecesarias aprovechando todos los recursos naturales que favorecen el confort humano, pueden catalogarse como 'climáticamente equilibradas'." 


\subsection{CONTEXTO BRASILEIRO}

No Brasil, a arquitetura atenta a princípios bioclimáticos ganhou maior força na década de 60 , com 0 movimento de migração de arquitetos por todo o território, incentivado pelo governo militar através dos planos de integração nacional. Estes arquitetos atuavam em regiões mais afastadas dos grandes centros, o que revelava uma necessidade cada vez maior de partir de condições locais para a construção, principalmente em face da realidade do interior, muito diversa da existente nas capitais. Com isso, realizavam obras utilizando sistemas construtivos tradicionais e materiais locais, seja por necessidade de adaptar-se a condicionantes específicos de determinada região, seja por harmonização à cultura e população locais.

Esta peregrinação de arquitetos por todo o país revelou uma crescente aproximação ao ambiente e à população local, numa atitude de maior respeito ao regionalismo geográfico. Assim, a arquitetura foi adquirindo diferenças peculiares em distintas regiões, passando a apresentar certa produção fora do eixo Rio - São Paulo:

Simultaneamente à construção de Brasília, devido à industrialização que se estende a todo o país, a linguagem arquitetônica de origens comuns vai se enquadrar em um novo contexto: diferenças econômicas, climáticas, tecnológicas e de programa conduzem a um processo de regionalização. (FICHER; ACAYABA, 1982)

Alguns jovens arquitetos da época colaboraram na disseminação destas novas idéias, não só pela arquitetura produzida mas principalmente pela contribuição teórica e influência no ensino universitário. De acordo com Segawa (1999), podem ser citados: Acácio Gil Borsoi (Pernambuco), Edgar Graeff (Rio Grande do Sul), Oscar Arine e João Timotheo da Costa (Mato Grosso), Marcelo Vivacqua (Espírito Santo), Nélson Serra e Neves, José Alberto de Almeida e Elbe Martins Ferreira (Ceará), Alcyr Meira e Milton Monte (Pará), Rubens Gil de Camillo (Mato Grosso do Sul), Gérson Castelo Branco (Piauí). Como arquiteto atuante neste propósito e contemporâneo a este movimento pode-se citar Severiano Porto:

Situação análoga e simultânea ocorreu com 0 arquiteto do Rio de Janeiro, Severiano Porto (n. em 1930): convidado para desenvolver projetos e fiscalizar obras em Manaus, capital do Estado do Amazonas, Porto foi o primeiro arquiteto a se transferir para o Estado, na segunda metade dos anos de 1960 [...] (SEGAWA, 1999) 
Uma das conseqüências deste esforço foi a inclusão da disciplina de conforto ambiental no currículo mínimo das escolas de arquitetura do país, em 1975, o que demonstrou a importância dada ao tema a partir de então. A questão da crise energética reforçou o debate sobre o assunto, levando inclusive à realização do "Seminário de Arquitetura Bioclimática", ocorrido em 1983, no Rio de Janeiro, onde tópicos sobre a produção e conservação de energia foram incorporados à questão (TOLEDO, 1999).

Manifestações neste sentido não chegaram a formar uma produção quantitativamente significativa no país, mas foram importantes como produções regionalistas, de linguagem arquitetônica condizente e integrada ao sítio, e se intensificaram com os debates ecológicos da década de 70 , quando houve um retorno da discussão do conceito de arquitetura bioclimática, que havia sido deixado de lado no período de auge da arquitetura moderna. Atualmente é um assunto intensamente debatido pelos estudiosos da área, e valorizado na arquitetura que se propõe a aplicar seus conceitos, já que na maior parte do Brasil existem elementos climáticos favoráveis a serem aproveitados na construção e 0 condicionamento térmico por vias predominantemente passivas é algo possível e fortemente incentivado, tendo em vista os benefícios resultantes.

\subsection{O ARQUITETO SEVERIANO PORTO}

Severiano Mário Vieira de Magalhães Porto, com seu trabalho na Amazônia, integra o grupo de arquitetos que propagou pelo território brasileiro uma arquitetura de feição regionalizada. Ele foi um dos arquitetos pioneiros a atuar na região amazônica divulgando novas idéias de tratamento dos espaços de acordo com o clima e valorizando aspectos importantes da arquitetura regional, dita "amazônica". Construiu a maior parte de suas obras na região, especialmente na cidade de Manaus-AM, onde viveu e trabalhou durante 36 anos. Com isso, pôde entrar em contato profundo não somente com o clima, mas com a sociedade e cultura locais, o que enriqueceu enormemente sua produção.

Após formar-se, em 1954, Porto trabalhou em escritório próprio no Rio de Janeiro por onze anos, em associação com o colega Mário Emílio Ribeiro. Foi para Manaus em 1965, inicialmente a convite do amigo Arthur Reis, que na época era governador do Estado do Amazonas, para atuar em alguns projetos que acabaram não sendo realizados. Isto o levou a envolver-se em outros projetos na região e mais tarde a mudar-se para a cidade, mantendo a associação com Ribeiro no escritório carioca.

Sua preocupação e envolvimento com as condições ambientais do sítio e com os materiais locais foram em grande parte resultantes do contato com os habitantes da região, os chamados "caboclos", que, baseados no conhecimento empírico, muito ensinaram sobre o modo de fazer local ao arquiteto. Isto 
foi, aos poucos, introduzindo-o ao ritmo de vida da região e integrando-o à nova realidade, revelando um constante "[...] esforço em trabalhar características regionais através da apropriação e reelaboração de técnicas e materiais tradicionais." (ZEIN, 1986). Assim foi reconhecendo e se adaptando às diferenças geográficas, climáticas, às diversidades culturais, riquezas naturais, e aprendendo a lidar harmonicamente com um sítio sensível à intervenção humana: "[...] without excluding his own background, the architect began a long and loving apprenticeship of the Amazonian way of life." (SEGAWA, 1993)

A idéia de arquitetura bioclimática se faz presente nas obras do arquiteto, e não se restringe apenas na procura em adaptar a arquitetura ao clima da região, mas também aos materiais, processos, condições locais, numa preocupação constante de integração entre construção e natureza.

Com olhar crítico e sensível Severiano Porto retoma os princípios da arquitetura amazônica autóctone, resgata as técnicas construtivas e tipologias tradicionais fundindo-as sutilmente ao repertório moderno. Essa atitude de abertura ao lugar resulta em uma arquitetura contextualizada, coerente com o meio físico e cultural em que se insere. (ROVO; OLIVEIRA, 2003)

Os princípios bioclimáticos nos projetos de Porto estão presentes na procura por uma linguagem coerente, voltada para as características regionais; na busca em utilizar soluções simples e originais, através do maior uso de recursos materiais locais; na preocupação em elaborar soluções arquitetônicas condizentes ao clima, que preservem e integrem o edifício à paisagem. A questão ambiental, desde 0 início, foi prioritária em seu trabalho, por se tratar de intervenções em um ambiente extremamente delicado. A arquitetura dita "amazônica" que 0 arquiteto desenvolveu foi resultante das dificuldades e peculiaridades encontradas, tanto de recursos como de mão-de-obra especializada. A inserção harmônica na paisagem circundante e a adequação ao clima são preocupações dominantes em suas obras, assim como o uso de estratégias projetuais que visem a obtenção de conforto ambiental para os usuários, o que inclui o uso da ventilação natural como uma das características mais marcante de seus projetos.

Tudo isto resultou em reconhecimento e mérito merecidos à sua produção arquitetônica, que teve Manaus como um de seus principais sítios de atuação, já que foi nesta cidade que grande parte de seus projetos foram construídos. Por isso, uma primeira análise das características climáticas da região se faz importante, já que as condições climáticas são essenciais para o estudo de uma edificação quanto ao grau de identificação com o lugar, considerando o conforto térmico dos indivíduos e a redução no consumo de energia. Em um segundo momento, realiza-se uma análise das características que a arquitetura desta região deve apresentar para garantir boas condições de conforto ambiental, 
dando atenção especial à ventilação natural. Por fim, discute-se um pouco a arquitetura produzida por Severiano Porto, enfatizando as características bioclimáticas e apresentando algumas de suas obras. 


\section{CONTEXTO REGIONAL: A CIDADE DE MANAUS}

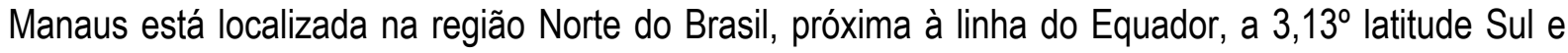
$60,02^{\circ}$ longitude Oeste. Situada no encontro dos rios Negro e Solimões, a 2.000 km do Atlântico, 0 município possui características climatológicas que se enquadram nos parâmetros de clima equatorial quente e úmido, clima característico da região Norte e de grande parte do litoral brasileiro, somando, de acordo com a Norma ABNT NBR 152201, um total de $53,7 \%$ da área do território nacional. A cidade assenta-se em uma área de relevo pouco pronunciado, uma extensa planície com declives suaves, de altitude entre 50 e 100 metros. De acordo com o censo do IBGE, realizado em 2000, a população está estimada em torno de 1,41 milhões de habitantes.

Após a abertura da Zona Franca, na década de 1970, Manaus passou por um acelerado desenvolvimento econômico, que ocasionou um crescimento intenso do município. A partir daí, observa-se a proliferação de soluções arquitetônicas importadas de outras regiões, com a forte presença de edifícios em concreto e fachadas de vidro, construções com características arquitetônicas inadequadas ao clima quente e úmido da região. Segundo Santos e Freitas (1998), a cidade vem sendo submetida, nos últimos anos, a um rigoroso racionamento de energia elétrica, já que a hidroelétrica de Balbina não é capaz de suprir a demanda energética do município. De acordo com Loureiro et al (2002), a ocupação inadequada do sítio e a excessiva pavimentação vêm transformando o clima da cidade em geral, acentuando os parâmetros de desconforto ambiental.

\subsection{CARACTERIZAÇÃO CLIMÁTICA DA REGIÃO}

O clima quente e úmido é caracterizado por apresentar temperaturas moderadamente altas e relativamente constantes; umidade constantemente elevada; céu encoberto e chuvas freqüentes, sobretudo em uma parte do ano; radiação sempre intensa, porém difusa devido à elevada nebulosidade. As Normais Climatológicas do município de Manaus, apresentadas a seguir, foram obtidas junto ao Instituto Nacional de Meteorologia (INMet) e são referentes ao período de 1961 a 1990:

\footnotetext{
${ }^{1}$ Norma ABNT NBR 15220 - Desempenho térmico de edificações. Parte 3: Zoneamento bioclimático brasileiro e diretrizes construtivas para habitações unifamiliares de interesse social. ABNT, set. 2003.
} 
Tabela 3.1 - Normais Climatológicas de Manaus (janeiro a junho de 1961-1990)

\begin{tabular}{|l|c|c|c|c|c|c|}
\hline \multicolumn{7}{|c|}{ Manaus (AM) Normal Climatológica - 1961 a 1990 } \\
\hline DADOS & JAN & FEV & MAR & ABR & MAI & JUN \\
\hline Temperatura máxima $\left({ }^{\circ} \mathrm{C}\right)$ & 30,5 & 30,4 & 30,6 & 30,7 & 30,8 & 31 \\
\hline Temperatura média $\left({ }^{\circ} \mathrm{C}\right)$ & 26,1 & 26 & 26,1 & 26,3 & 26,3 & 26,4 \\
\hline Temperatura mínima $\left({ }^{\circ} \mathrm{C}\right)$ & 23,1 & 23,1 & 23,2 & 23,3 & 23,3 & 23 \\
\hline Precipitação total $(\mathrm{mm})$ & 260,1 & 288,3 & 313,5 & 300,1 & 256,3 & 113,6 \\
\hline Umidade relativa $(\%)$ & 86 & 87 & 88 & 87 & 87 & 83 \\
\hline Nebulosidade $(0-10)$ & 7,1 & 7,1 & 7,2 & 7,1 & 6,6 & 5,7 \\
\hline Pressão atmosférica $(\mathrm{hPa})$ & 1003,2 & 1003,2 & 1003,3 & 1003,4 & 1004,2 & 1005,1 \\
\hline Evaporação total $(\mathrm{mm})$ & 52 & 44,9 & 52,5 & 49,4 & 52 & 64,1 \\
\hline
\end{tabular}

Tabela 3.2 - Normais Climatológicas de Manaus (julho a dezembro de 1961-1990/ média anual)

\begin{tabular}{|l|c|c|c|c|c|c|c|}
\hline \multicolumn{7}{|c|}{ Manaus (AM) Normal Climatológica -1961 a 1990 } \\
\hline DADOS & JUL & AGO & SET & OUT & NOV & DEZ & ANO \\
\hline Temperatura máxima $\left({ }^{\circ} \mathrm{C}\right)$ & 31,3 & 32,6 & 32,9 & 32,8 & 32,1 & 31,3 & 31,4 \\
\hline Temperatura média $\left({ }^{\circ} \mathrm{C}\right)$ & 26,5 & 27 & 27,5 & 27,6 & 27,3 & 26,7 & 26,7 \\
\hline Temperatura mínima $\left({ }^{\circ} \mathrm{C}\right)$ & 22,7 & 23 & 23,5 & 23,7 & 23,7 & 23,5 & 23,3 \\
\hline Precipitação total $(\mathrm{mm})$ & 87,5 & 57,9 & 83,3 & 125,7 & 183 & 216,9 & 2286,2 \\
\hline Umidade relativa $(\%)$ & 80 & 77 & 77 & 79 & 81 & 85 & 83 \\
\hline Nebulosidade $(0-10)$ & 5,1 & 4,8 & 5,3 & 6,2 & 6,6 & 6,8 & 6,3 \\
\hline Pressão atmosférica (hPa) & 1005,4 & 1004,6 & 1003,8 & 1002,8 & 1002,4 & 1002,6 & 1003,6 \\
\hline Evaporação total $(\mathrm{mm})$ & 82,1 & 102,6 & 99,5 & 87,8 & 70,9 & 59,7 & 817,5 \\
\hline
\end{tabular}

Manaus tem temperatura média anual superior a $26^{\circ} \mathrm{C}$, céu predominantemente encoberto e amplitudes térmicas baixas, tanto diárias quanto sazonais (dias quentes e úmidos, noites com temperaturas mais amenas e umidade também elevada). Como se situa próxima à linha do Equador, a incidência dos raios solares é sempre intensa, apesar de difusa. A umidade relativa do ar é alta, em torno de $80 \%$, com elevados índices pluviométricos (em média $2.285 \mathrm{~mm}$ ao ano). A variação climática anual é demarcada principalmente pelas épocas de maior e menor pluviosidade - de dezembro a maio e de junho a novembro, respectivamente - o que indica duas estações definidas: inverno e verão.

Em relação à incidência dos ventos, a direção predominante é Nordeste, podendo variar para Norte ou Leste ocasionalmente. Os ventos possuem baixas velocidades, problema que é agravado pelo adensamento elevado das construções, principalmente na área central.

Como complementação deste levantamento, são apresentados alguns dados climatológicos do município relativos aos anos de 2000 a 2005, coletados na Estação Meteorológica do aeródromo de Eduardo Gomes-AM. Estes dados, apresentados a seguir, foram obtidos junto ao Instituto de Controle 
do Espaço Aéreo (ICEA) de São José dos Campos-SP². Através destes dados pode-se notar um ligeiro aumento da temperatura do ar e uma redução da precipitação nos últimos anos, consequêencias da crescente urbanização e desmatamento da região.

Tabela 3.3 - Dados climatológicos de Manaus (janeiro a junho de 2000-2005)

\begin{tabular}{|l|c|c|c|c|c|c|}
\hline \multicolumn{7}{|c|}{ Manaus (AM) Dados climatológicos - 2000 a 2005 } \\
\hline DADOS & JAN & FEV & MAR & ABR & MAI & JUN \\
\hline Temperatura máxima $\left({ }^{\circ} \mathrm{C}\right)$ & 35 & 33,7 & 34 & 34,1 & 34 & 33,7 \\
\hline Temperatura média $\left({ }^{\circ} \mathrm{C}\right)$ & 27,2 & 26,4 & 26,4 & 26,3 & 26,6 & 26,5 \\
\hline Temperatura mínima $\left({ }^{\circ} \mathrm{C}\right)$ & 22 & 22,2 & 22,7 & 22,3 & 21,8 & 21,8 \\
\hline Precipitação total $(\mathrm{mm})$ & 252,3 & 274,4 & 368,9 & 343,5 & 277,7 & 138,7 \\
\hline Umidade relativa média $(\%)$ & 86,8 & 90,4 & 89,9 & 91,1 & 90,1 & 88,6 \\
\hline Nebulosidade (0-8) & 5,6 & 6 & 6 & 6 & 5,8 & 5,2 \\
\hline Pressão atmosférica média (hPa) & 1000,9 & 1001,5 & 1001,6 & 1001,7 & 1002,2 & 1003,4 \\
\hline
\end{tabular}

Tabela 3.4 - Dados climatológicos de Manaus (julho a dezembro de 2000-2005/ média anual)

\begin{tabular}{|l|c|c|c|c|c|c|c|}
\hline \multicolumn{10}{|c|}{ Manaus (AM) Dados climatológicos - 2000 a 2005 } \\
\hline DADOS & JUL & AGO & SET & OUT & NOV & DEZ & ANO \\
\hline Temperatura máxima $\left({ }^{\circ} \mathrm{C}\right)$ & 34,5 & 36 & 36,3 & 36,4 & 35,6 & 35,3 & 36,8 \\
\hline Temperatura média $\left({ }^{\circ} \mathrm{C}\right)$ & 27 & 27,7 & 27,5 & 27,7 & 27,7 & 26,9 & 27 \\
\hline Temperatura mínima $\left({ }^{\circ} \mathrm{C}\right)$ & 21,6 & 22 & 21,8 & 22,3 & 22,4 & 22 & 21,1 \\
\hline Precipitação total $(\mathrm{mm})$ & 67,3 & 84,6 & 113,2 & 195,2 & 134,8 & 183,2 & 2070,5 \\
\hline Umidade relativa média $(\%)$ & 85,7 & 82 & 83,3 & 83,7 & 85,4 & 89,4 & 86,3 \\
\hline Nebulosidade $(0-8)$ & 4,4 & 4,5 & 5,2 & 5,7 & 5,8 & 6 & 5,5 \\
\hline Pressão atmosférica média $(\mathrm{hPa})$ & 1003,5 & 1003,1 & 1001,9 & 1000,7 & 1000,2 & 1000,5 & 1001,8 \\
\hline
\end{tabular}

\footnotetext{
2 O levantamento destes dados foi elaborado pela Subdivisão de Climatologia Aeronáutica (PCA), da Divisão de Pesquisa e Desenvolvimento do Instituto de Controle do Espaço Aéreo (ICEA), visando atender solicitação da autora. Para elaboração do trabalho, foram utilizadas informações do Banco de Dados Climatológicos (BDC), registradas em formulários meteorológicos preenchidos na Estação Meteorológica de Superfície do aeródromo de Eduardo Gomes, localizado em Manaus, que compõem o acervo do Arquivo Histórico de impressos meteorológicos do Instituto de Controle do Espaço Aéreo (ICEA). Os dados médios apresentados foram calculados a partir das tabelas contidas no Anexo 13.3.
} 


\section{CLIMA QUENTE E ÚMIDO: CONFORTO TÉRMICO}

A preocupação com o conforto térmico é fator essencial para o projeto de uma edificação com princípios bioclimáticos e que atenda às exigências de conforto humanas. 0 cuidado em adaptar a construção às características regionais, aos materiais e condições locais, alia-se à atenção primordial que deve ser dada às questões climáticas. Por isso, devem-se adotar soluções arquitetônicas visando um resultado térmico desejável, diante das variações dos fatores climáticos locais. Os elementos climáticos que devem ser considerados para a produção de uma edificação confortável são: temperatura, umidade, radiação solar, movimento de ar e precipitação.

Para o clima quente e úmido, a umidade elevada é o fator primordial que ocasiona desconforto térmico, pois a sensação de calor aumenta, apesar das temperaturas externas não serem muito altas - em torno de 25 a $30^{\circ} \mathrm{C}$. Portanto, a arquitetura nesta zona deve, basicamente, responder de forma adequada à ação das chuvas, do sol e do alto nível de umidade. Estratégias básicas a serem adotadas consistem em reduzir a absorção da radiação solar através do sombreamento e da refletância, favorecer a penetração dos ventos dominantes através da ventilação natural, prover máxima proteção contra as chuvas e seu escoamento rápido.

Os materiais utilizados nas vedações externas devem ter baixa inércia térmica, devido ao regime térmico pouco variável deste clima, onde o acúmulo de calor durante o dia pode elevar a temperatura interna durante a noite, já que o calor não se dissipa, podendo originar desconforto. "Aquellos materiales que reflejan más radiación de la que absorben, y que expelen rápidamente la cantidad absorbida en forma de radiación térmica, producirán temperaturas más bajas dentro de la edificación." (OLGYAY, 1998).

Entretanto, em edifícios de uso unicamente diurno, como estabelecimentos comerciais, por exemplo, o uso de materiais de inércia alta pode ser aceitável. Isto ocorre porque o fluxo de calor que incide nas vedações durante o dia é inicialmente consumido para seu aquecimento, e somente durante a noite, quando a temperatura externa é geralmente mais baixa, este calor é retransmitido por convecção e por radiação ao ambiente interno. Este fenômeno denomina-se atraso térmico, e o uso deste tipo de solução pode auxiliar na manutenção de temperaturas internas mais amenas nas horas do dia em que as temperaturas externas são maiores.

Tais estratégias bioclimáticas são de baixo custo energético - já que não necessitam de sistemas mecânicos - e visam trazer maior conforto térmico (KOENIGSBERGER et al, 1977). 
To summarize, the requirements to be satisfied by the design and construction of a building in a warm-wet climate are these: provision of continuous and efficient ventilation; protection from the sun, rain and insects, prevention of internal temperature elevation during the day and minimization during the evening and night. (GIVONI, 1976)

A observação dos dados climáticos locais é extremamente importante para definir as estratégias projetuais a serem utilizadas. As estações meteorológicas cobrem geralmente os dados climáticos gerais - macroclima - de uma região, que devem ser complementados com os dados do microclima específico do local de intervenção, obtidos diretamente no sítio. "Tanto o más importante que el clima general de la región es el entorno próximo a la arquitectura, el ambiente cercano que genera lo que llamamos 'microclima de un lugar'." (SERRA, 1999)

No estudo do microclima, devem ser levados em consideração os fatores que afetam diretamente a área de intervenção, como topografia, presença de rios ou massas d'água próximas, grau de exposição ao sol e aos ventos, obstruções do entorno natural e construído e suas características (forma, volume, altura, tipo de revestimento), presença de cobertura vegetal natural. 0 grau de refletância solar das superfícies próximas (tanto do terreno como de edificações adjacentes) também é um importante determinante da natureza do microclima. Estes fatores podem significar diferenças de temperatura e umidade de uma região para outra. Deve-se aproveitar ao máximo o terreno, a vegetação e as estruturas circundantes para favorecer a ventilação e a criação de áreas sombreadas.

Quanto à edificação, as características gerais do clima quente e úmido mostram que uma das estratégias mais apropriadas para obtenção de conforto térmico é a proteção contra a incidência direta e difusa da radiação solar, tomando o cuidado para que isto não bloqueie os ventos dominantes.

Independente da necessidade do uso do ar condicionado ou do suprimento do conforto pela ventilação natural, o sombreamento é essencial em todo 0 ano na cidade, devendo-se procurar eliminar ou amenizar os efeitos da permanente incidência de radiação solar, contribuindo para a eficiência energética das edificações. (LOUREIRO et al, 2002)

Isto deve ser observado desde o projeto inicial, na configuração geral do edifício - volumetria, altura, orientação, forma do telhado, projeções e outros detalhes arquitetônicos. Devem ser evitadas fachadas maiores mais expostas ao sol, principalmente fachada Oeste, e é importante 0 uso adequado de mecanismos de sombreamento para proteger as aberturas da radiação solar, tanto interna como externamente. Estes elementos podem ser fixos, ajustáveis ou retraíveis e de uma grande variedade de formas arquitetônicas e configurações geométricas, ficando isto a critério do arquiteto. Os elementos 
externos são mais eficientes do que os internos, pois barram a radiação antes de atingir o interior, prevenindo a dissipação de calor. São eles os brises-soleil, cobogós, muxarabis, pergolados, beirais amplos.

Para proteção contra a radiação solar, deve-se procurar, portanto, um sombreamento eficiente. Para isto, o telhado é elemento fundamental, por ser o componente do edifício mais exposto à radiação solar. De acordo com Bittencourt et al (2005), em baixas latitudes o telhado recebe cerca de dois terços da radiação solar total que incide na construção. Por isso, a cobertura deve funcionar como elemento de proteção das vedações e aberturas, por meio de beirais longos e varandas cobertas, que também auxiliam na proteção das chuvas. "As varandas são elementos de transição entre o interior e o exterior, protegendo da radiação excessiva e da chuva, mas permitindo a iluminação e ventilação naturais." (BITTENCOURT et al, 2005). A cobertura deve ser de materiais leves e refletores, de preferência com duas camadas (telhado mais forro) e um espaço para ventilação entre elas.

Para minimizar a transferência de calor das superfícies externas aquecidas pelo sol, além das características térmicas dos materiais utilizados (baixa inércia térmica), é de extrema importância o uso de superfícies externas refletoras. Por isso são indicadas as cores claras, que em geral possuem absortância baixa e maior índice de reflexão da radiação incidente, sendo, portanto, mais apropriadas.

O uso adequado da vegetação no entorno próximo contribui para a criação de um microclima mais favorável. A vegetação auxilia na absorção da radiação solar, e seu processo de evaporação pode reduzir a temperatura do ar, além do sombreamento que proporciona. As zonas exteriores semiprotegidas pela vegetação moderam o clima circundante, refrescando a parte interna da edificação e seus arredores: árvores e arbustos situados próximos ao edifício protegem as aberturas da incidência direta do sol, devendo tomar-se o devido cuidado para não barrar a ventilação; a capa vegetal no solo esfria os acessos à edificação.

La diferencia de temperaturas superficiales entre la hierba y el asfalto puede superar fácilmente los $15^{\circ} \mathrm{C}$. La temperatura del aire en la zona microclimática (de 0,30 a 1,20 metros) situada bajo estas superficies presenta también apreciables diferencias del orden de $6^{\circ} \mathrm{C}$ o incluso mayores. (CAMOUS; WATSON, 1986)

Em clima quente e úmido, onde a amplitude térmica é baixa e a temperatura do ar raramente ultrapassa a temperatura do corpo, proporcionar conforto térmico aos usuários pela ação dos ventos (ventilação de conforto) passa a ser extremamente favorável, por acelerar a evaporação do suor da pele e facilitar as trocas de calor por convecção, reduzindo assim a sensação de calor, como afirma Givoni (1976): "The ventilation conditions inside a building are among the primary factors determining human health, comfort and well-being." Também de acordo com Peixoto et al (2003) e Bittencourt et al 
(2003), a ventilação natural é a estratégia bioclimática mais eficiente, neste clima, para se obter conforto térmico por vias passivas. Segundo estudo realizado por Loureiro et al (2002), há necessidade do uso da ventilação natural em $65,2 \%$ das horas de um ano, na cidade de Manaus, para obtenção de conforto térmico. Este assunto será, então, estudado mais a fundo, dada a importância do tema para a região e por se tratar de um recurso muito presente nas obras de Severiano Porto para obtenção de conforto térmico.

\subsection{A IMPORTÂNCIA DA VENTILAÇÃO NATURAL}

The simplest strategy for improving comfort when the indoor temperature, under still air conditions, seems to be too warm is by daytime ventilation - providing comfort through higher indoor air speeds. [...] This is particularly the case when the humidity is high and so the higher air speed increases the rate of sweat evaporation from the skin, thus minimizing the discomfort from the wet skin. (GIVONI, 1994)

Como a sensação de pele úmida é uma das causas centrais de desconforto em climas quentes e úmidos, o fluxo de ar em determinadas velocidades através de um edifício pode ampliar as condições de conforto, pelo efeito de resfriamento fisiológico trazido pela evaporação do suor da pele. É o que se chama de "ventilação de conforto". Por estar relacionada à sensação térmica, a ventilação é um dos fatores mais importantes que determinam o conforto térmico neste clima. Sua importância não está apenas na obtenção de conforto, mas também por razões de salubridade dos ambientes e de seus habitantes, já que o favorecimento à penetração dos ventos dominantes traz uma renovação contínua do ar interno de um recinto (ventilação higiênica).

A ventilação é apontada, frequentemente, como a estratégia bioclimática mais eficiente para obtenção de conforto térmico nos espaços urbanos e arquitetônicos. Além disso, o alcance social dessa estratégia é indiscutível. (BITTENCOURT et al, 2005)

Apesar de Manaus ser caracterizada por possuir ventos de baixa velocidade, o que de início pode dificultar a ventilação natural, o uso adequado de estratégias de ventilação também pode gerar construções eficazes para o clima. Por isso, uma ventilação permanente direcionada à zona de atividade de um ambiente é uma estratégia bioclimática importante para o clima quente e úmido e, segundo Loureiro et al (2002), é a solução de cerca de dois terços das horas de desconforto térmico ao longo do ano na cidade de Manaus, já que produz resultados satisfatórios em lugares onde a temperatura externa não ultrapassa muito os $30^{\circ} \mathrm{C}$. Além disso, um aproveitamento apropriado das 
correntes naturais de ar pode reduzir o consumo de energia dos edifícios, por se tratar de um sistema passivo de condicionamento: "Proper air movement control lessens the demand for energy, thus reducing the expense of providing a comfortable home." (BOUTET, 1987)

$O$ aumento da velocidade do ar eleva a capacidade evaporativa e a perda de calor por convecção, 0 que pode amenizar os efeitos da alta umidade. À medida que o movimento de ar aumenta, o limite superior de conforto também se eleva e há uma aparente redução na temperatura efetiva (temperatura calculada em função da temperatura de bulbo seco, umidade relativa e velocidade do ar, usada para avaliação do calor em ambientes).

A velocidade máxima de ar que pode ser atingida não está relacionada a condições de conforto térmico, mas sim a distúrbios que possam ser gerados às pessoas, como derrubar objetos, voar papéis, desarrumar as roupas. A determinação das condições de ventilação satisfatórias depende também da função a que se destina o ambiente, como uma sala de aula, por exemplo, onde uma velocidade de ar muito elevada pode causar distúrbio no trabalho.

De acordo com Serra (1999), cada $0,3 \mathrm{~m} / \mathrm{s}$ de velocidade do ar equivalem a uma redução de $1^{\circ} \mathrm{C}$ na sensação térmica da pessoa que está sendo submetida a essa corrente de ar. De acordo com Boutet (1987), para que se atinja a situação desejável, o ideal é que se possa sempre manter um controle flexível do movimento de ar, baseando-se em três parâmetros: "A balance between maximum air movement, human comfort, and function of the spaces is required." (BOUTET, 1987).

A ventilação natural consiste no deslocamento de ar através do edifício, pela disposição de aberturas em suas vedações. As correntes de ar originam-se por diferenças de pressão entre as áreas externas e internas, que, por sua vez, possuem duas fontes diferentes: as correntes de ar existentes no exterior e a diferença de temperatura entre 0 ar interno e externo. Portanto, existem duas possibilidades de uso da ventilação natural no projeto de um edifício: o movimento de ar produzido pela ação dos ventos - a ventilação cruzada - e o movimento de ar por diferença de temperatura - o chamado "efeito chaminé". Elas podem atuar sozinhas, em conjunto ou em oposição, sempre dependendo das condições atmosféricas e do desenho do edifício. Serão examinadas mais aprofundadamente a seguir.

\subsubsection{Movimento de ar na edificação}

As diferenças de pressão entre dois pontos distintos de um edifício é que determinam a direção e velocidade potenciais para ocorrência de ventilação. Quando uma corrente de ar entra em contato com uma edificação, as faces expostas ao vento sofrem sobrepressões e as faces não expostas sofrem 
subpressões (figuras 4.1 e 4.2). A face a barlavento é a zona de fluxo livre de ar; a área onde ocorre a separação entre o fluxo livre e a região de recirculação de ar é chamada de camada limite; já a zona oposta à corrente de ar é chamada de zona de sombra de vento, onde o ar se encontra em repouso e pode gerar alguns turbilhões (OLGYAY, 1998).

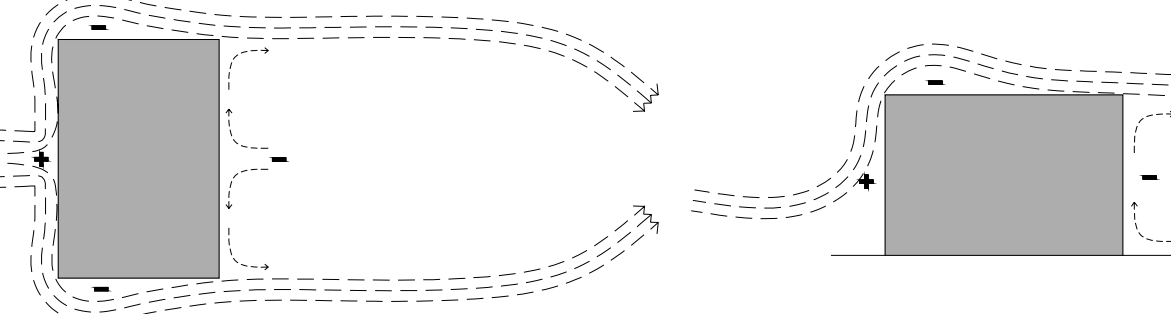

Figuras 4.1 e 4.2: Esquemas de corrente de ar ao redor de uma edificação - planta e corte (Adaptado de: OLGYAY, 1998)

A ventilação contínua é requisito primordial no clima quente e úmido, e possui relação direta com diversos aspectos de desenho do edifício e do entorno. Segundo Allard (1998), os principais aspectos a serem considerados são relacionados à forma e implantação do edifício, paisagismo e obstáculos do entorno, bem como direção, velocidade e freqüência dos ventos dominantes da região. As características microclimáticas do entorno contribuem para aumentar ou diminuir a intensidade dos ventos, assim como alterar sua direção. As edificações adjacentes podem barrar ou canalizar as correntes de ar, dependendo de sua distância e volume. A vegetação é um excelente meio de controle das correntes de ar, podendo filtrá-las, guiá-las, obstruí-las, ou inclusive acelerar ou reduzir sua velocidade em torno da edificação. Para isso, é necessário o controle da forma, densidade e rigidez das massas vegetais, e principalmente uma disposição apropriada, de acordo com as intenções de projeto (figura 4.3).
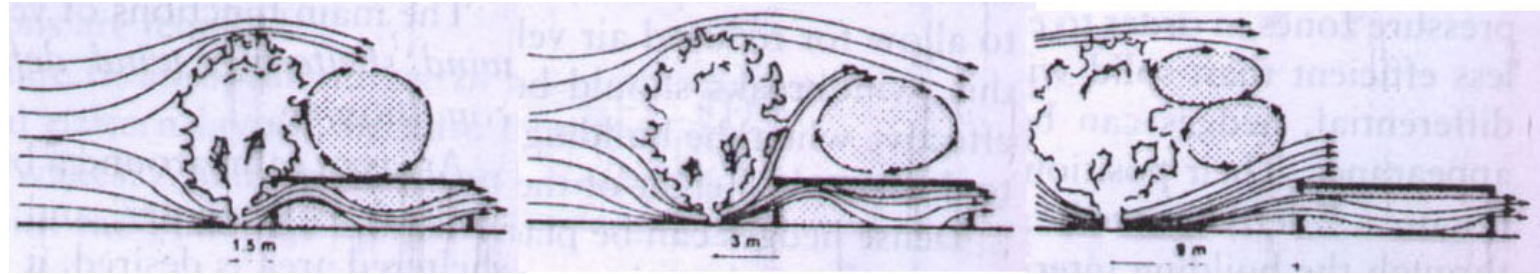

Figura 4.3: O efeito de uma árvore sobre a direção do vento, com relação à sua distância do edifício 1,5m, 3m, 9m (ALLARD, 1998)

Quanto aos aspectos relacionados ao edifício, a ventilação natural depende dos seguintes fatores: 
orientação, localização, forma e características construtivas. Além, é claro, de aspectos relacionados às aberturas, que serão tratados mais adiante. A orientação do edifício altera o movimento de ar natural e, portanto, afeta o padrão e a velocidade do ar. Não necessita, necessariamente, ser perpendicular à direção do vento, mas deve ser determinada em função dos ventos dominantes locais, a fim de criar zonas de alta e baixa pressão. Para o clima de Manaus, os ventos são fator preponderante na orientação de uma edificação, como afirma Givoni (1976): "This is particularly so in humid regions, where the primary physiological comfort requirement is for air motion." A incidência solar pode ser controlada por outros meios, como o uso de vedações adequadamente isoladas, aberturas sombreadas e superfícies externas refletoras (cores claras). Em Manaus, as orientações ideais para captação e renovação dos ventos em edificações são Norte, Nordeste e Leste, que são as direções predominantes dos ventos no município.

A localização de uma edificação deve ser determinada de acordo com o seu entorno e microclima. Para uma ventilação satisfatória, os edifícios devem estar relativamente afastados uns dos outros, para que haja uma boa circulação de vento ao redor deles. Assentamentos densos criam zonas neutras, de ar parado; mas quando as edificações estão espaçadas, o vento tem a possibilidade de recuperar sua velocidade após passar por um edifício e antes de atingir o seguinte. 0 espaçamento mínimo indicado depende da forma de implantação dos edifícios. Segundo Olgyay (1998), para construções dispostas em fileira o espaçamento ideal é de sete vezes a altura, o que garante uma ventilação satisfatória a todos os edifícios.

Quanto ao movimento de ar interno, uma boa ventilação depende da pressão do ar em todas as faces do edifício, o que determina o correto posicionamento das aberturas. Por isso, a geometria do edifício é fator essencial. Edificações alongadas, com uma grande quantidade de vedações voltadas para a área externa, facilitam a ocorrência de ventilação. Construções abertas, onde há forte integração entre os espaços internos e externos, são características construtivas que favorecem o fluxo de ar. Assim como 0 uso de varandas, pérgolas, elementos vazados, lanternins, aberturas zenitais, dentre outras estratégias, que permitem permeabilidade às correntes de ar, ao mesmo tempo sombreando e filtrando a intensa luminosidade natural.

Outra característica importante relacionada à forma da edificação, para o clima quente e úmido, é a elevação da construção relativamente ao solo. É uma estratégia arquitetônica que proporciona melhor ventilação, por posicionar as aberturas na zona de maior fluxo de ar e acima da zona de máxima umidade. Também liberta o edifício das cargas térmicas dissipadas pelo terreno durante o seu arrefecimento noturno. "O uso de pilotis pode melhorar a eficiência da ventilação interna de uma edificação em cerca de $20 \%$, contanto que se leve em conta uma distância mínima de 1,0m acima do 
solo e o vento fique livre de obstáculos embaixo das construções." (BITTENCOURT et al, 2005). Além disso, um correto posicionamento das aberturas e uma planta livre de obstáculos internos são diretrizes importantes para maior aproveitamento do fluxo de ar na ventilação natural.

A forma e declividade do telhado influenciam o movimento de ar em quantidade, velocidade e padrão. Telhados duplos com espaço para ventilação do ático, além de contribuírem na ventilação interna auxiliam na proteção contra o aquecimento solar. Os beirais também são elementos importantes para a ventilação natural. Auxiliam a direcionar o fluxo de ar para o interior do edifício e aumentar sua velocidade, devido ao aumento da pressão positiva próxima à abertura que eles provocam (figura 4.4): "In addition to providing shade, horizontal projections establish some unique air movement patterns. Their extension beyond the wall surface can help capture the exterior air movement and bring it into the interior spaces." (BOUTET, 1987).

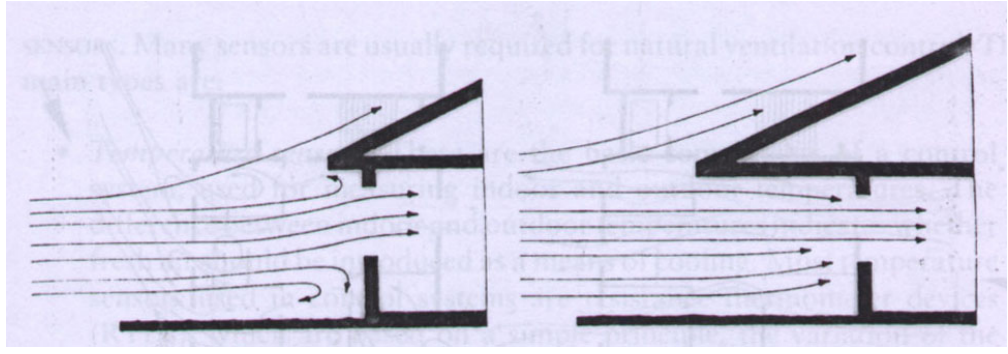

Figura 4.4: Efeito sobre o vento, ao aumentar o tamanho do beiral (ALLARD, 1998)

Outro fator de extrema importância para ventilação de conforto é a necessidade do fluxo de ar atingir a zona de ocupação da edificação. Quando se trata de sensação térmica, de nada adianta um edifício ser bem ventilado se o fluxo de ar não atingir diretamente as pessoas que ocupam o ambiente. Aqui entram dois conceitos importantes: os conceitos de fluxo de ar e trocas de ar. O número de trocas de ar de um ambiente não necessariamente determina o padrão e velocidade do fluxo de ar: "A building may have many air changes per unit length of time, and yet if the air does not flow through the living zone and if the air speeds are low, the occupants may still not experience a sensation of cooling." (REED, 1953). Por isso, para ventilação de conforto é o fluxo de ar que é significativo, e não as trocas de ar. Ele deve atingir a zona de atividade do ambiente, sendo a melhor posição para as aberturas de entrada do ar de 0,5 a $1,5 \mathrm{~m}$ acima do piso.

\subsubsection{Ventilação cruzada}

Na ventilação cruzada, as aberturas são dispostas em fachadas de diferentes orientações do edifício, 
sendo que as aberturas de entrada devem situar-se nas zonas de alta pressão e as de saída nas zonas de baixa pressão (figura 4.5). Não basta haver mais de um acesso ao exterior em um edifício, mas sim posições adequadas em relação ao vento. Se houver vento mas não houver diferenças de pressão entre as aberturas, não haverá corrente cruzada (figura 4.6). Por isso, um fator essencial no projeto de um edifício com ventilação cruzada é o correto posicionamento das aberturas, especialmente das aberturas de entrada, que determinam o modelo do fluxo de ar.

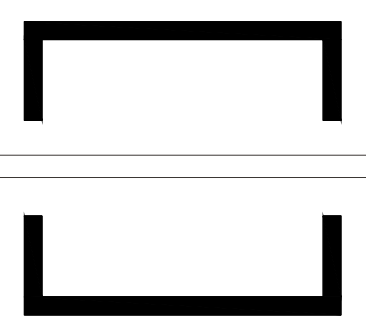

Figura 4.5: Esquema de ventilação com corrente cruzada

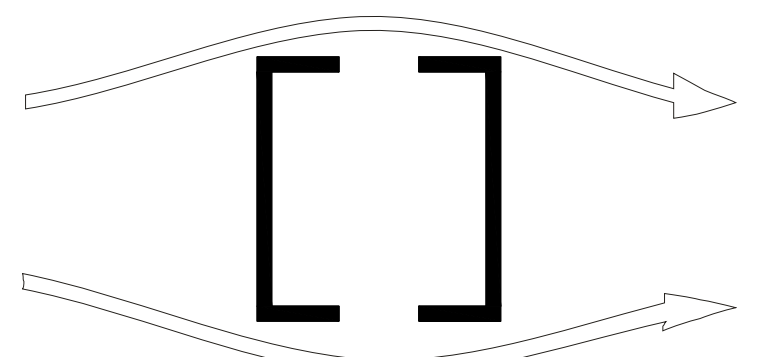

Figura 4.6: Exemplo de caso com vento e sem corrente cruzada

Melhores condições gerais de ventilação são obtidas quando 0 ar tem que mudar de direção no ambiente, ao invés de ir diretamente da entrada para a saída. Em janelas de paredes opostas, quando o vento entra perpendicularmente, 0 ar atinge uma zona limitada da área interna, e cruza a uma velocidade mais alta (figura 4.7). Já quando entra obliquamente ou tem que mudar de direção na área interna, a velocidade é mais baixa porém atinge um volume interno maior, proporcionando uma ventilação mais satisfatória do ambiente como um todo (figura 4.8). Isto ocorre devido a um fenômeno denominado turbulência, que é uma importante variável de conforto. Uma maior turbulência e variação da direção do fluxo de ar dentro das construções podem aumentar as trocas de calor por convecção, aumentando conseqüentemente a sensação de conforto (GIVONI, 1976).

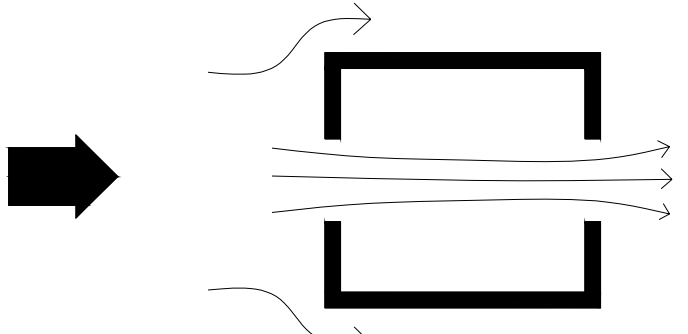

Figura 4.7: Fluxo de ar incidindo perpendicular à abertura (Adaptado de: GIVONI, 1976)

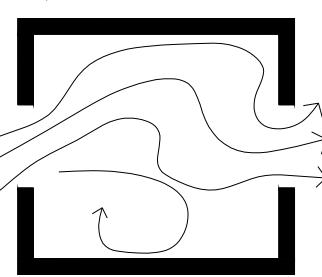

Figura 4.8: Fluxo de ar incidindo oblíquo à abertura (Adaptado de: GIVONI, 1976) 
Em aberturas localizadas em paredes adjacentes, o vento perpendicular à janela amplia a variação na direção do fluxo, o que resulta em uma ventilação melhor distribuída do que o oblíquo (figuras 4.9 e 4.10).

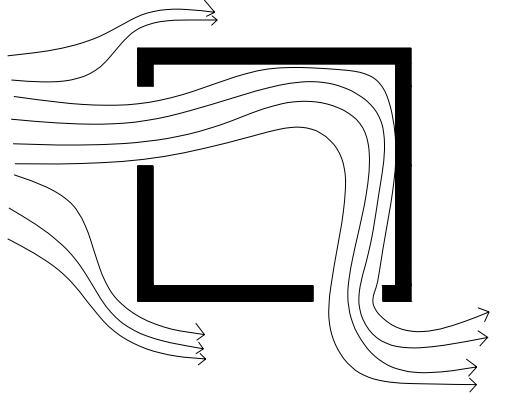

Figura 4.9: Fluxo de ar incidindo perpendicularmente, em aberturas adjacentes (Adaptado de: REED, 1953)

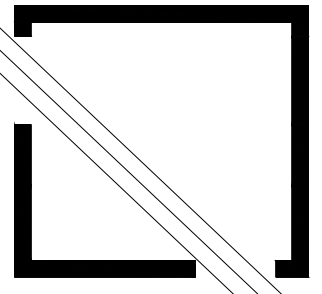

Figura 4.10: Fluxo de ar incidindo obliquamente,em aberturas adjacentes (Adaptado de: REED, 1953)

O tipo de abertura afeta diretamente o desempenho da ventilação cruzada, pois influi tanto na resistência oferecida ao fluxo de ar como no seu direcionamento e intensidade (as aberturas serão tratadas com maior detalhamento no item 4.1.4). Elementos externos, como projeções horizontais e verticais, brises, telas para insetos, vegetação próxima, também influem no padrão e velocidade do vento, podendo direcioná-lo, incrementá-lo ou reduzi-lo. As wing-walls, por exemplo, são extensões verticais utilizadas para criar áreas de alta pressão próximas às aberturas de entrada, direcionando a corrente de ar para o interior do edifício.

Figura 4.11: Wing walls utilizadas para direcionar a corrente de ar

Subdivisões do espaço interno alteram o movimento de ar reduzindo sua velocidade e dificultando a ventilação cruzada, por isso os espaços devem ser desobstruídos o máximo possível. Quando a divisão encontra-se mais próxima à abertura de entrada de ar, ocorre uma redução acentuada na 
velocidade; melhores condições de ventilação são obtidas quando ela se encontra mais próxima à saída.

\subsubsection{Efeito chaminé}

A ventilação por diferença de temperatura, ou efeito chaminé, consiste na formação de uma coluna ascendente de ar, e sua exaustão por aberturas na parte superior da edificação ou pela cobertura. Ela é ocasionada pelas diferenças de pressão originadas pelas diferenças de temperatura entre 0 ar interno e externo ao edifício. 0 ar externo, que geralmente possui temperaturas inferiores, irá penetrar pelas aberturas mais baixas do ambiente; já o ar interno, de temperatura mais elevada, irá ascender e sair pelas aberturas mais altas, criando assim um fluxo de ar. Este tipo de ventilação adquire importância fundamental em cidades como Manaus - caracterizada por ventos de fraca incidência, onde são comuns momentos de calmaria - já que pode auxiliar na criação de uma corrente forçada de ar.
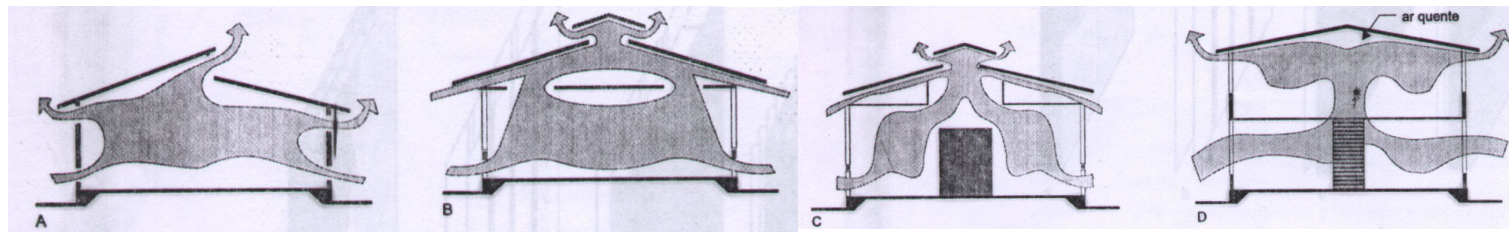

Figura 4.12: Exemplos de aplicação do efeito chaminé (HERTZ, 1998)

O efeito chaminé dependerá não só das diferenças de temperatura externa e interna, mas também da organização e do tamanho das aberturas, e principalmente da distância vertical entre elas. Quanto maior o tamanho e a diferença de altura entre as aberturas de entrada e saída de ar, maior o fluxo de ar. Pode funcionar em edifícios com torres de ventilação ou com pé-direito alto e aberturas localizadas na cobertura. Estas aberturas, além de funcionarem como saída do ar mais quente, são uma forma de proporcionar ventilação do ático, auxiliando na prevenção do aquecimento excessivo do telhado devido à exposição à radiação solar, como recomenda Costa (1982): "[...]aberturas nas coberturas, as quais além de ocasionarem substancial acréscimo da ventilação natural, arrastam, pela formação de uma camada de ar móvel entre o forro e o telhado, o calor da insolação que, incidindo sobre as telhas, aquece o forro." 


\subsubsection{Aberturas}

Air movement within a building is affected by the orientation, size, placement, ratio and types of openings, which alter the inertia, pressure differentials, and buoyancy characteristics of airflow. The openings may guide the air into specific patterns and regulate its velocities. (BOUTET, 1987)

Com relação às aberturas, a configuração do fluxo de ar no interior de uma construção é determinada por três fatores principais: posição, tamanho e tipo. $O$ correto posicionamento das aberturas de entrada e saída do ar determina o padrão de distribuição do fluxo de ar pelo local. As entradas devem estar localizadas nas zonas de alta pressão e as saídas nas zonas de baixa pressão. Porém, isto não é suficiente, já que o principal objetivo da ventilação de conforto em clima quente e úmido é que o fluxo de ar atinja a zona de atividade do recinto, para produzir um resfriamento fisiológico, como afirma Reed (1953): "In order to produce a cooling effect on the occupants of the building in hot humid weather, the air movement must be within the living zone of the building around the occupants bodies; simply providing openings does not necessarily allow the air to flow within the living zone."

O fluxo de ar pode ser direcionado ou distribuído, dependendo da função a que se destina o ambiente. Em um dormitório, por exemplo, pode-se direcionar o vento para a cama, que é a principal região que se deseja atingir; já em uma sala de aula, o vento deve ser distribuído por todo o ambiente, de modo que atinja todos os alunos.

Também é de extrema importância a localização de outros componentes arquitetônicos nas proximidades das aberturas, tais como divisórias internas e painéis verticais ou horizontais adjacentes a elas, como protetores solares e marquises, por exemplo. Eles podem influir no padrão e velocidade do movimento de ar.

Quanto ao tamanho, a abertura menor - seja de entrada ou de saída - é que determina a velocidade média do ar internamente. $O$ aumento simultâneo das aberturas de entrada e de saída resulta em velocidades internas do ar mais elevadas. A combinação de uma entrada pequena com uma saída maior produz um movimento de ar concentrado, de maior velocidade, limitado a uma pequena seção do ambiente - 0 chamado "efeito Venturi". Entradas e saídas de tamanhos similares resultam em uma ventilação mais distribuída (GIVONI, 1976).

A porcentagem e o tamanho das aberturas em uma edificação determinam o seu grau de porosidade. Para o clima quente e úmido o ideal é que haja uma alta porosidade, pois se deseja que o edifício seja o mais aberto e integrado possível ao meio externo. "For maximum summer cooling by natural wind 
forces, inlet openings should be designed as large as feasible for speed of air flow, with flexibility, of course, for closing when desirable." (REED, 1953)

Além de um bom projeto de localização e tamanho de aberturas, a correta escolha do tipo de esquadria também influi na obtenção do movimento de ar interno desejado. 0 tipo de esquadria é um elemento fundamental para a qualidade da ventilação natural. O fluxo de ar natural nem sempre é como se espera, às vezes pode falhar completamente, e muda constantemente de direção e sentido. Por isso, o desenho das aberturas deve aproveitar ao máximo o movimento de ar, e ter flexibilidade para reduzi-lo quando for desejável. Ele determina o direcionamento do fluxo de ar, a possibilidade de mudança de orientação do fluxo e a regulagem de sua intensidade, através de um controle flexível do movimento de ar.

There are many types of windows on the market which when used for inlet openings in buildings result in a variety of air patterns. Some have extreme limitations. We should know the performance and limitations of the different types of windows in order to employ them intelligently in particular situations. (REED, 1953)

O tipo de esquadria e seu desenho determinam alguns critérios de desempenho. São eles: a área real de abertura, que determina a área máxima de ventilação; a possibilidade de separação das correntes de ar frio e quente; a possibilidade de ser regulável pelo usuário; a contribuição na distribuição do fluxo de ar pelo local; a estanqueidade ao ar e à chuva (MASCARÓ, 1991). Outras características importantes são a acessibilidade e facilidade de operação pelo usuário.

Existem diversos modelos tradicionais de esquadrias, encontrados no mercado, que variam bastante quanto ao desempenho em relação ao movimento de ar. As figuras a seguir apresentam alguns modelos que comumente se encontra nas construções:

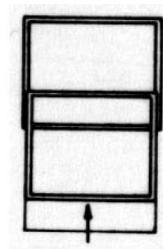

(a)

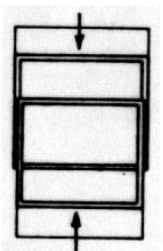

(a)

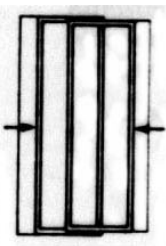

(b)

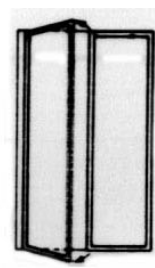

(c)

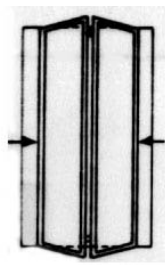

(c)

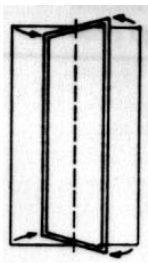

(d)

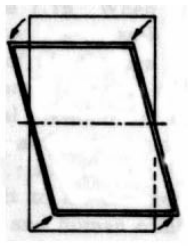

(d)

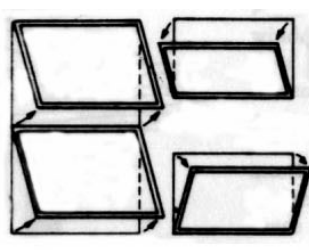

(e)

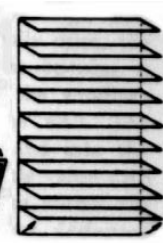

(f)

Figura 4.13: Modelos tradicionais de esquadrias: (a) guilhotina; (b) de correr; (c) folhas de dobradiça; (d) pivotante; (e) máximo ar; (f) basculante (BOUTET, 1987) 
abrir, no máximo, 50\% de sua área total. Elas geralmente não afetam o padrão do movimento de ar, e o fluxo, ao entrar no ambiente, permanece na mesma altura horizontal da abertura. Algumas permitem a opção de regular se 0 ar entra pela parte superior ou inferior da abertura, ou até pelas duas partes ao mesmo tempo.

Esquadrias com folhas de dobradiça, pivotantes e basculantes têm área real de abertura de até no máximo 100\%, ou seja, permitem total abertura. As pivotantes e as basculantes possuem a vantagem de possibilitar o direcionamento do fluxo de ar. As basculantes também estabilizam o fluxo e criam um movimento de ar laminar, podendo, além de tudo, prover a separação entre as correntes de ar frio e quente, quando o sistema de abertura permite abrir as folhas separadamente. As esquadrias denominadas máximo ar, em comparação às demais, são as que possuem o pior desempenho. Além de possuírem área real de abertura extremamente reduzida, sua folha, quando se abre, barra o vento e impede sua entrada no ambiente, obstruindo o fluxo de ar.

Outros tipos de abertura muito comuns na arquitetura brasileira, e muito utilizados por Severiano Porto em suas obras, são os elementos vazados, também chamados de cobogós, e os muxarabis (grelhas de madeira). Eles satisfazem as exigências combinadas de filtro da luz natural e sombreamento constante, além de permitirem ventilação permanente. 


\section{O ARQUITETO SEVERIANO PORTO}

Em conversa com Severiano Porto, realizada no decorrer da pesquisa ${ }^{3}$, pôde-se compreender como se deu o processo de desenvolvimento de seu trabalho na Amazônia, que o fez produzir a arquitetura que apresenta hoje. $\mathrm{O}$ arquiteto comentou todas as etapas de sua carreira, desde o período de formação, falou do aprendizado com os caboclos, mostrou alguns projetos, comentou obras. Apresenta-se aqui uma análise de seu trabalho, resultante das informações obtidas nesta conversa, juntamente com um vasto levantamento das publicações existentes a respeito de sua obra e da transcrição do curso ministrado pelo arquiteto na Universidade de São Paulo, Escola de Engenharia de São Carlos, em $2003^{4}$.

Estudar a arquitetura de Severiano Porto tem o intuito de resgatar, em termos de conforto ambiental, obras e projetos significativos na história da arquitetura brasileira. Este estudo pretende evidenciar o potencial da ventilação natural como recurso para resfriamento em climas quentes e úmidos, contribuindo para a ampliação e difusão de estratégias de projeto que auxiliem na obtenção de maior conforto térmico, minimizando os gastos com energia e o impacto do ambiente construído sobre 0 meio. A análise aqui empreendida trata um pouco do desenvolvimento de sua carreira desde seu período de formação até o fechamento de seu escritório em Manaus. Posteriormente, apresenta um estudo mais específico de sua produção, através de uma breve apresentação e análise de algumas de suas obras na cidade de Manaus-AM.

\subsection{FORMANDO E AFIRMANDO UMA POSTURA ARQUITETÔNICA}

Severiano Porto foi um dos arquitetos brasileiros pioneiros a atuar na região amazônica, onde viveu e trabalhou durante 36 anos, sempre mantendo associação com o colega Mário Emílio Ribeiro, no escritório carioca. Hoje é um arquiteto conhecido nacional e internacionalmente, e, de acordo com Segawa, um dos mais importantes do final do século XX: "Atualmente, as obras de Severiano Porto formam - ao lado das produzidas por Niemeyer - o conjunto de projetos mais conhecido de um

\footnotetext{
3 Entrevista realizada em 30/03/2005, no escritório do arquiteto em Niterói-RJ. A transcrição integral da entrevista encontrase no Anexo 13.1

4 Curso 'Arquitetura, Estrutura e Construção', ministrado por Severiano Porto no período de 1 a 4 de julho de 2003 no anfiteatro Jorge Caron da EESC-USP, São Carlos-SP. A transcrição do curso foi um trabalho desenvolvido pela autora na disciplina de pós-graduação 'Tópicos Especiais de Arquitetura e Urbanismo 2', ministrada pelos professores Hugo Segawa e Akemi Ino, no primeiro semestre de 2004.
} 
arquiteto brasileiro contemporâneo na América Latina e Europa." (SEGAWA, 1989).

A Amazônia ocupa quase $60 \%$ do território brasileiro, e representa cerca de dois terços da floresta tropical existente no mundo. Apesar de vir sofrendo, nas últimas décadas, um progressivo processo de exploração predatória, possui uma grande riqueza natural, sendo, segundo Santo (2002), a maior reserva de madeira para construção do mundo, e ainda hoje há diversas regiões de difícil acesso e intervenção. Quando Porto chegou a Manaus, em 1965, a região apresentava pouquíssimos profissionais do ramo da construção, e era rara a preocupação em adaptar a arquitetura às condições locais. O arquiteto, então, despontou como pioneiro na preocupação em divulgar essa idéia, e introduziu novos padrões de projeto e métodos de construção, sempre procurando adequar-se à cultura local e utilizar materiais regionais.

Arquitetura é um conjunto de fatores que se entrelaçam e se agrupam de acordo com as necessidades de um programa, as condições específicas de uma área, os recursos da sua região, suas condições ecológicas, tecnologia a ser empregada, antiga, regional e todas as demais existentes em sua época, recursos financeiros, etc. Tudo isso ordenado, transformado em espaço de maneira sensível, lógica, técnica e bela. (PORTO, 2005, grifo nosso; informação verbal) ${ }^{5}$

Esta definição de arquitetura, dada pelo próprio arquiteto, explicita suas preocupações fundamentais no ato de projetar, e demonstra a importância dada a princípios bioclimáticos. A arquitetura, para ele, mostra-se algo muito além do aspecto puramente formal, mas decorrente da pesquisa das necessidades e condições oferecidas por cada região em particular, que resulta em uma atitude de produzir edificações em harmonia com o meio e combater os modelos e soluções transportados de outras regiões e inadequados à realidade local.

Quando Severiano chegou a Manaus, havia poucos profissionais qualificados trabalhando na construção, não havia faculdades de arquitetura ou engenharia civil, e portanto era rara a preocupação em adaptar a obra às condições locais. $O$ arquiteto questionou a arquitetura que estava sendo produzida na época, distante da realidade local e que tomava como referência "o moderno" divulgado pelas revistas. $O$ contato com os habitantes locais e as edificações que produziam foi um dos motivos de reflexões que formaram os seus conceitos, a favor da construção mais apropriada ao clima.

Para Severiano Porto, a arquitetura deve responder às necessidades e às circunstâncias locais, esquecendo modelos importados de outras regiões ou de outras culturas dominantes. 'À medida que assumirmos a nossa época, com tudo 0

\footnotetext{
5 Definição de arquitetura fornecida por Severiano Porto durante a entrevista com o arquiteto, realizada em 30/03/2005. A
} frase estava sendo elaborada na época. 
que isso implica - uma imensa quantidade de informações sobre o que já foi realizado, conhecimento de técnicas regionais, de novos materiais etc. -, alcançaremos a liberdade para elaborar projetos mais belos e mais racionais, adequados ao clima onde serão executados, às regiões e a seus usuários [...]' (Severiano Porto in SABBAG, 1985) ${ }^{6}$

Ao mudar-se para Manaus, o arquiteto tira partido dos conhecimentos pré-existentes, adquiridos no Rio de Janeiro, para aplicá-los às novas condições. Assim, procura coerência entre sua produção e a tecnologia possível, os materiais disponíveis e também o conhecimento da mão-de-obra local. 0 emprego da madeira, material abundante na região, foi conseqüência natural do intuito em utilizar materiais adequados ao local, e da procura em produzir uma arquitetura que "se insere harmoniosamente no meio em que é produzida" (ZEIN, 1986), integrando princípios culturais, ambientais e tecnológicos. Seu trabalho foi caminhando, portanto, para um uso de tecnologias apropriadas à região e adaptadas à realidade local. "Não foi um processo deliberado, mas um comportamento natural decorrente das possibilidades e das necessidades da região." (Severiano Porto in ZEIN, 1986) ${ }^{7}$

O arquiteto soube se aproveitar da sabedoria da população local, que tinha muito o que ensinar: como fazer, viver e morar na Amazônia. Foi observando e convivendo com o homem em seu próprio habitat que Severiano tomou consciência da necessidade de revalorização do uso da madeira e das técnicas caboclas, mais adequadas às circunstâncias locais, bastante específicas. No momento em que iniciou seu trabalho na Amazônia, notou que existia um certo preconceito com o uso da madeira por parte da população regional, por ser um material muito utilizado pela população mais carente em suas residências. Porto procurou reverter este conceito e mostrar que a madeira é um material nobre, adequado ao clima e à realidade local, e que pode ser utilizado em construções de qualidade. Mostrou isto ao construir sua própria residência em madeira numa época em que o material ainda era visto com grandes restrições (1971). "Devemos adotar soluções que atendam a insolação, aos ventos, as chuvas, as nossas condições de mão-de-obra, de material de construção e aí incluímos a madeira farta e abundante em nossas matas." (PORTO, 1971)

A importância da adequação à região está sempre presente em seu discurso. Demonstra um intenso aprendizado por observação e vivência do clima, além do aprendizado com o caboclo - que produz uma arquitetura espontânea, baseada em toda a experiência de vida no local e no contato direto com o clima - numa atitude de respeito ao homem em seu meio. 0 arquiteto sempre procurou adaptar 0 que

\footnotetext{
${ }^{6}$ Entrevista exclusiva cedida por Severiano Porto a SABBAG, 1985.

7 Entrevista exclusiva cedida por Severiano Porto a ZEIN, 1986.

8 Entrevista exclusiva cedida por Severiano PORTO (1971) a Bom Dia.
} 
queria fazer com o que, no meio, conheciam e sabiam fazer. Ao relatar seu processo de projeto e de construção das obras, Porto demonstra que a habilidade que ganhou com o manuseio de técnicas e materiais veio de aprendizado com os próprios construtores. As soluções muitas vezes iam aparecendo no decorrer da obra, e eram propostas e executadas pelos próprios operários, segundo informação dada pelo arquiteto (PORTO, 2005; informação verbal).

Sua arquitetura integra e trabalha fatores simples como sol, vento, chuvas, luz, qualidade dos materiais, tecnologias acessiveis. Estratégias projetuais que visam a obtenção de conforto ambiental são dominantes em seus projetos, e estão presentes em suas obras. As publicações encontradas sobre sua arquitetura também enfatizam este aspecto de seu trabalho.

A preocupação de Severiano na Amazônia centrava-se não somente no emprego dos materiais, mas no aproveitamento dos ventos, na proteção máxima contra o sol e nas condições topográficas. 'Questões como natureza e clima são inerentes à profissão do arquiteto', observa ele [...] (SABBAG, 2003)

[...] Severiano Porto afirma que o segredo de sua arquitetura é o uso da ventilação cruzada e o emprego moderado da luz natural. Para isso, antes de desenvolver qualquer projeto, ele costuma estudar o regime dos ventos e a posição do sol durante todo o ano, no local da construção. Sua meta é sempre encontrar - com os materiais da região - a fórmula mais simples, adequada e ao mesmo tempo criativa, para cada problema. (GOMES, 1985)

\subsection{UM POUCO DE SUA TRAJETÓRIA}

Severiano Porto nasceu em 1930 em Uberlândia-MG, mas logo aos cinco anos de idade mudou-se para o Rio de Janeiro. Cursou arquitetura na Faculdade Nacional de Arquitetura da Universidade do Brasil (atual Universidade Federal do Rio de Janeiro - UFRJ), nos anos 1950 a 1954. O prestígio social da profissão, alcançado nas décadas de 40 e 50, refletiu na disseminação do ensino de arquitetura pelo país. As escolas tornaram-se importantes centros de discussão das novas idéias entre os jovens e, entre elas, a Faculdade Nacional de Arquitetura, do Rio de Janeiro, foi a principal irradiadora de profissionais do período, pois contribuiu de forma significativa para a formação de arquitetos e difusão da linguagem carioca. Este é um dado marcante na carreira de Porto e muito enfatizado pelo arquiteto em seu discurso. Ele relata que sua formação influenciou todo o desenvolvimento de sua carreira, inclusive nos últimos anos, em que começou a exercer atividades acadêmicas. 
Foi neste contexto que Severiano adquiriu sua formação, em anos de euforia econômica e produção arquitetônica intensa, cujo centro estava na cidade do Rio de Janeiro, então capital do país. As palavras do próprio arquiteto esclarecem o momento: "Na época viviam-se coisas muito criativas na arquitetura, até sem perceber ou sentir claramente, era uma fase de importantes exemplos de nossa arquitetura, embora esparsos e fruto de um país jovem e sem muitos compromissos." (Severiano Porto in PENTEADO et al, 1986) ${ }^{9}$.

Na década de 1960 intensificou-se o movimento de migração de profissionais por todo o território brasileiro; um movimento iniciado na década anterior, com a criação de escolas de arquitetura em diversas regiões do Brasil, e incentivado pelo governo militar, a partir de 1964, através dos planos de integração nacional, que tinham o objetivo de explorar territórios ainda pouco ocupados no país:

Nesse ímpeto de modernização e integração nacional, a arquitetura vai conhecer novos recantos geográficos, até então inexplorados. (SEGAWA, 1999)

A política de ocupação do interior do país no período pós-1964 definiu uma estratégia de ocupação e integração de regiões isoladas e pouco desenvolvidas do Brasil, como o Centro-Oeste e a Amazônia. (SEGAWA, 1999).

A transferência de conhecimentos de regiões mais desenvolvidas para outras menos desenvolvidas aliou-se à crescente disseminação do uso de materiais locais, de menor custo e mais fácil acesso, e assim materiais como o tijolo e a madeira foram ganhando espaço junto ao concreto aparente. Era cada vez mais clara a constatação da necessidade de partir de condições locais para a construção, principalmente em face da realidade do interior, muito diversa da existente nas capitais. "Todo aquele arrojo da arquitetura racionalista [...] no interior não encontrava uma receptividade muito grande. Então, o que se podia fazer não era a arquitetura desejada, mas a arquitetura possível." (Luiz Gastão C. Lima in BASTOS, 2003)

Severiano Porto pode ser citado como parte deste movimento. Após onze anos de trabalho em escritório próprio no Rio de Janeiro, foi para a Amazônia no período em que se iniciou um processo de incentivo de desenvolvimento da região, que, de acordo com o governo militar, desempenhava um papel estratégico na chamada "integração nacional", por ser um território pouquíssimo explorado, por sua localização e recursos naturais apresentados, o que o tornava economicamente atrativo. "In the mid 60s, the Brazilian government started a more elaborate strategy to establish a definite policy for Amazonian occupation." (SEGAWA, 1993).

Foi uma época de criação de órgãos regionais de desenvolvimento e de disponibilização de recursos

9 Entrevista exclusiva cedida por Severiano Porto a PENTEADO et al, 1986. 
para a implantação de toda uma infra-estrutura necessária na região para permitir um maior desenvolvimento econômico: abertura de rodovias, aeroportos, instalações portuárias, construção de hidrelétrica para produção de energia, implantação e ampliação do sistema de telecomunicações. Tudo isto abriu um imenso campo de trabalho na área da construção, e permitiu que Porto iniciasse um trabalho intenso e ativo na região.

Como parte na criação de infra-estrutura, Severiano foi chamado para realizar o projeto da Companhia Amazonense de Telecomunicações em Manaus, a CAMTEL (que depois veio a se chamar Telamazon), em 1966. A companhia foi criada em 1965, com o objetivo de instalar e explorar comercialmente 0 sistema de telecomunicações de todo o Estado do Amazonas. Posteriormente, o arquiteto também realizou o projeto de 23 Centrais Telefônicas no interior do Estado, já no processo de expansão da empresa.

Em 1967 foi criada a Zona Franca de Manaus, dentro deste processo de exploração econômica da região, que seria um centro industrial e agropecuário, com uma área para comércio de importação e exportação, com incentivos fiscais especiais. Este empreendimento contribuiu consideravelmente para o rápido processo de urbanização e crescimento do município. Porto foi convidado para realizar o projeto de sua sede, a SUFRAMA (Superintendência da Zona Franca de Manaus), em 1971.

Nos anos 1970, algumas crises ocorridas no setor energético e com relação ao petróleo fizeram surgir uma discussão, ainda incipiente, sobre os limites dos recursos energéticos do planeta e a necessidade de preservação ambiental. No campo da arquitetura, voltou à discussão as vantagens dos sistemas construtivos tradicionais, utilizados em países subdesenvolvidos como alternativas tecnológicas mais acessíveis e baratas, pelo menor impacto ambiental que seu uso proporciona. Neste período, Porto já realizava obras utilizando sistemas construtivos tradicionais e materiais locais, como a madeira, material abundante na região e muito utilizado pelo arquiteto. Foi através de aprendizado com a população local - os "caboclos" - que ele desenvolveu técnicas de como manusear a madeira: "A sua prática reflete uma tradição regional, derivada de outros construtores: os carpinteiros navais." (SEGAWA et al, 1988).

Porto foi 0 arquiteto precursor em divulgar a madeira como um material de construção nobre na Amazônia. O material já era muito utilizado em construções na região, por ser disponível em abundância e de baixo custo, porém era visto com restrições, por ser usado apenas pelos mais pobres para construírem suas próprias moradias. Porto se aproveitou da facilidade de manuseio pela mão-deobra local, e realizou diversas obras em madeira, o que acabou auxiliando na redução do preconceito e na inserção do material em outros contextos. "Confessa Severiano que precisou quebrar muitos tabus e resistências para que essa interpretação da cultura regional acontecesse." (SABBAG, 2003). "Hoje, é 
um valor incorporado à moradia de classes sociais nem sempre atentas a 'inovações' dessa natureza." (SEGAWA et al, 1988). Algumas obras importantes de Porto, em que o uso da madeira foi explorado tanto plástica e espacialmente como estruturalmente, em diferentes processos de experimentação, são a residência do arquiteto, de 1971; a pousada na Ilha de Silves, de 1979-83; e o Centro de Proteção Ambiental de Balbina, de 1983-88.

A construção com materiais "alternativos", de técnicas construtivas artesanais, como tijolo, taipa e madeira, foi mais recorrente nas regiões Norte, Nordeste e Centro-Oeste, devido ao precário desenvolvimento econômico e tecnológico destas regiões neste período, e às dificuldades trazidas pelo relativo isolamento em que elas se encontravam.

No início dos anos 1980, os debates mundiais sobre o pós-modernismo, apesar de não terem sido muito intensos no Brasil, auxiliaram, segundo Mário Aloísio Barreto Melo (ARQUITETOS, 1990) ${ }^{10}$, a reacender os regionalismos e incentivar um debate sobre a diversidade na arquitetura nacional. $\mathrm{Na}$ verdade, o que se pôde realmente observar nesses anos foi uma maior tolerância, em relação ao momento anterior, à pluralidade de pensamentos e posicionamentos. Foram estas manifestações e discussões de cunho regionalista que trouxeram à tona novos valores, como a necessidade de diálogo da edificação com seu contexto urbano, a adequação ao clima e a ao ambiente natural, a importância da preservação da história e cultura locais. Segundo Mauro Neves (ARQUITETOS, 1990), a "verdade única" que foi perseguida nos anos 50 a 70 caiu em descrédito nos anos 80 , revelando em seu lugar um país de muitas e grandes diferenças regionais.

A discussão deste tema fez com que algumas obras de arquitetos que haviam se deslocado pelo território brasileiro nas décadas precedentes fossem então reconhecidas: "Nos anos de 1980, colhemse, no âmbito arquitetônico, os primeiros frutos dos programas de interiorização da economia no país." (SEGAWA, 1999). O trabalho dos arquitetos Severiano Porto e Mário Emílio Ribeiro, iniciado na Amazônia na década de 1960, foi nessa década reconhecido e divulgado, como uma produção brasileira de forte caráter regional e grande valor arquitetônico.

Nos anos de 1980, a arquitetura desenvolvida por Severiano Porto e Mário Emílio Ribeiro passou a ser vista como uma importante referência nas discussões sobre tendências e caminhos para a arquitetura nacional. [...] Sua arquitetura se enquadrava numa das discussões mais importantes travadas no continente, a revisão da arquitetura moderna, pela introdução de características culturais, construtivas, climáticas, em seus postulados genéricos. (BASTOS, 2003).

Porto e Ribeiro receberam consagração internacional em 1985, no auge das discussões sobre

10 Catorze arquitetos comentam os anos 80 na revista Projeto (1990). 
regionalismo, quando seu trabalho foi exposto na Bienal de Arquitetura de Buenos Aires, em que receberam o "Premio Universidad de Buenos Aires" pelo projeto da pousada na llha de Silves. Lá também ocorreu o I SAL (Seminário de Arquitetura Latino-Americana), em que houve forte discussão da identidade cultural dos países latino-americanos e a valorização da produção arquitetônica mais vinculada a características regionais, com diversas exposições, na qual a de Severiano foi uma grande surpresa. Esta bienal marcou a carreira do arquiteto, como ele mesmo explicita:

O que caracterizou a década de 80 foi a grande divulgação da produção arquitetônica de todas as regiões do Brasil. 0 marco mais significativo do fato acima foi a Mostra da Arquitetura Brasileira, que aconteceu em Buenos Aires, em 1985, onde cerca de 300 arquitetos brasileiros apresentaram mais de 1000 trabalhos sobre temas diversos, realizados em vários pontos do território, permitindo, pela primeira vez, que se tivesse uma idéia geral do que estava sendo produzido no país, em termos de arquitetura. (Severiano Porto in ARQUITETOS, 1990)

No ano seguinte, 1986, Porto e Ribeiro receberam um prêmio do IAB-RJ, ao serem nomeados personalidades do ano. Em 1987, na XXV premiação do IAB Nacional, os projetos para o Campus da Universidade do Amazonas e para o Centro de Proteção Ambiental de Balbina receberam um prêmio, e todo o conjunto de suas obras recebeu menção honrosa no Prêmio Anual Nacional. Neste momento, Severiano era considerado um dos maiores e melhores arquitetos contemporâneos do país, o que foi freqüentemente citado por colegas em artigos e entrevistas. Como exemplo:

Arquiteto Antônio Carlos Sant'Anna Jr., formado pela FAU/USP em 1974:

Sobre exemplos significativos da arquitetura brasileira nos últimos dez anos, citaria - Severiano, não como paradigma, mas pela boa arquitetura que produz. (ARQUITETOS, 1990)

Arquiteto Mário Aloísio Barreto Melo, formado pela UFPE em 1973:

Não por acaso o arquiteto Severiano Mário Porto é o grande nome de nossa arquitetura nessa década. Começamos a sentir que, independentemente do aspecto tecnológico, a arquitetura que está se fazendo no Paraná difere da de Minas, Recife, Manaus, etc. Isso é fundamental, pois envolve uma adequação maior ao clima, regionalismo, tecnologias e tipologias. (ARQUITETOS, 1990)

Severiano Porto deixou Manaus em 2001, atualmente vive em Niterói-RJ e se dedica a atividades acadêmicas e em organizar o seu acervo. $O$ arquiteto é hoje reconhecido e admirado pela crítica por seu trabalho na região amazônica, que é visto como uma arquitetura vinculada à natureza e à cultura 
do lugar; suas obras são reconhecidas como exemplos pioneiros de uma arquitetura regional de qualidade na Amazônia.

\subsection{PRODUÇÃO ARQUITETÔNICA NA CIDADE DE MANAUS-AM}

Manaus é sede de grande parte dos projetos e obras construídas pelo arquiteto Severiano Porto, somando cerca de 140 no total. Algumas das principais obras que podem ser citadas, onde se destacam as soluções projetadas para obtenção de conforto e diferentes estratégias de ventilação natural, são: Sede da Superintendência da Zona Franca de Manaus (SUFRAMA), de 1971; residência do arquiteto, de 1971; Campus da Universidade do Amazonas, de 1973; residência Robert Schuster, de 1978; pousada de caça e pesca (llha de Silves), de 1979-83; Centro de Proteção Ambiental de Balbina (município de Presidente Figueiredo-AM), de 1983-88; Aldeias Infantis SOS Brasil, de 1994.

A seguir, apresenta-se uma breve descrição de algumas obras do arquiteto (não selecionadas para as etapas seguintes), como complemento à revisão bibliográfica. Tem o intuito de discorrer de forma mais generalizada sobre a produção de Porto em Manaus e as diversas soluções projetuais apresentadas por ele, como uma primeira aproximação ao tema. Inclui uma breve análise sobre os principais aspectos de implantação, relação com o entorno, conforto térmico e ventilação natural, sob enfoque bioclimático, já com apreciações empreendidas pela própria autora. Através deste primeiro levantamento foi possível escolher três obras para um estudo mais aprofundado, como parte do desenvolvimento da pesquisa. As obras selecionadas para as etapas seguintes são: o Campus da Universidade do Amazonas, a Sede da Superintendência da Zona Franca de Manaus e as Aldeias Infantis SOS Brasil.

\subsubsection{Restaurante Chapéu de Palha, 1966}

Esta obra, uma das primeiras executadas por Porto em Manaus, vale ser citada pelo marco que constitui na carreira do arquiteto. Executada em materiais típicos da região - tais como madeira e palha - numa época em que estes materiais eram vistos com um grande preconceito pelos habitantes locais, a obra surpreendeu pela repercussão que alcançou. Recebeu um prêmio do Instituto dos Arquitetos na VII premiação anual do IAB-RJ, que afirmou a brasilidade da arquitetura do autor.

Pouco tempo depois, Porto tomou conhecimento de uma reprodução que havia sido feita de sua obra, 
em Boa Vista-RR, o que inicialmente gerou problemas de autoria, mas depois trouxe até uma certa satisfação, por representar a divulgação de um modo de construção regional.

Era a primeira vez que eu via na região copiar um modelo regional, porque geralmente se procurava sempre modelos de fora. Adaptando inclusive para a realidade deles, que era da palha de buriti. Aí eu não pedi mais nada, deixei ficar porque eu achei que foi um avanço nesse sentido. (PORTO, 2003; informação verbal)
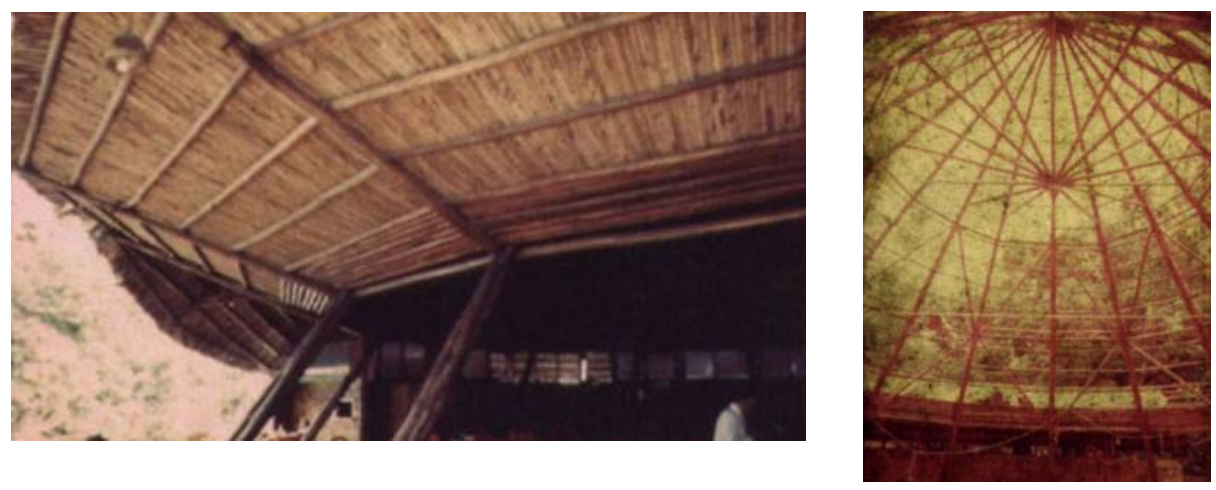

Figuras 5.1 e 5.2: Restaurante Chapéu de Palha (HESPANHA, 2005)

A construção apresentava estrutura e vedação em madeira presente na região - a aquariquara - e cobertura em palha, o que rendeu um baixo custo final e uma rápida execução, já que os operários de construção tinham grande conhecimento sobre o material; como afirma o próprio arquiteto: "Eles têm a maior facilidade para mexer com esse tipo de solução." (PORTO, 2003; informação verbal) ${ }^{11}$ É a primeira obra de Severiano que apresenta tal tipo de solução, que se torna recorrente na sua produção arquitetônica.

Além da atenção dada aos materiais e técnicas regionais, a obra destaca-se também pela preocupação em adaptar-se às condições climáticas locais, como pode ser observado no uso apropriado de materiais de baixa inércia térmica, adequados ao clima da região, e no uso de beirais ao redor de todo o restaurante para proteger da insolação. O formato de "chapéu" dado ao edifício resulta em um pédireito elevado, de $12 \mathrm{~m}$, que facilita a ascensão do ar quente, garantindo temperaturas mais amenas à zona de ocupação (solução posteriormente utilizada em outras obras, como o Centro de Proteção Ambiental de Balbina e as Aldeias Infantis SOS Brasil). Falta, porém, uma saída de ar quente pela cobertura para ocorrer ventilação por efeito chaminé.

\footnotetext{
11 Afirmação do arquiteto quando explica sobre a construção do restaurante.
} 
A obra não apresenta muitos registros e foi demolida alguns anos após a construção.

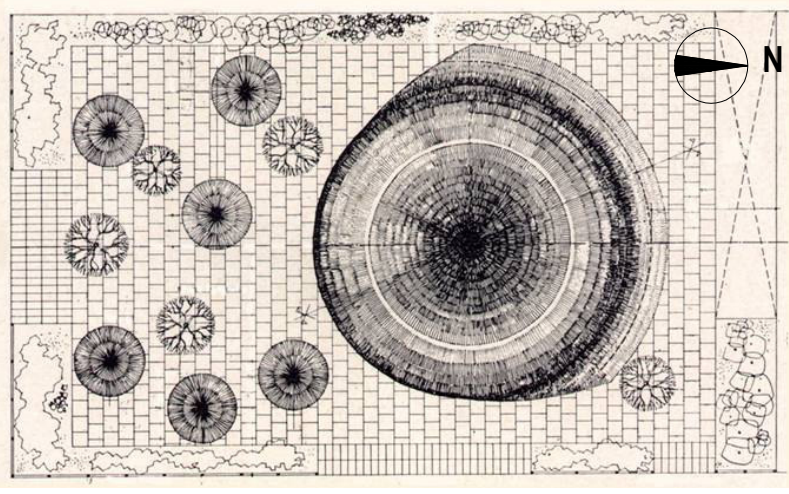

Figura 5.3: Implantação (GAGLIARDI, 1968)

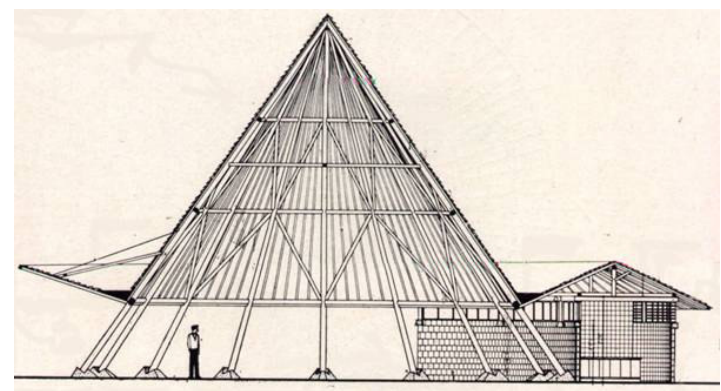

Figura 5.4: Corte (GAGLIARDI, 1968)

\subsubsection{Residência do arquiteto, 1971}

No projeto para sua própria residência, de 1971, Porto utilizou a madeira numa época em que o material ainda era visto com grandes restrições. A casa necessitava ser de rápida construção (cerca de seis meses) e de baixo custo, e a madeira contribuiu muito para alcançar esses objetivos. 0 arquiteto conseguiu reduzir o valor da construção em cerca de $25 \%$ em relação às casas construídas pela COHAB-AM da época (GAGLIARDI, 1968). Uma diretriz inicial importante para o projeto foi a intenção de atender às condicionantes ambientais do local, sem causar grande impacto na paisagem, e procurar a integração máxima com a vegetação do entorno.

Ao nos propormos a projetar e construir nossa própria casa procuramos chegar a uma solução que além de atender às condições ecológicas da região, pudesse integrá-la quase que espontaneamente ao terreno, com as colunas de troncos de Maçaranduba e Itaúba saindo diretamente do gramado que chega até as paredes, como também utilizar a mão-de-obra local em toda a sua plenitude. (Severiano Porto in PRÊMIO, 1971) ${ }^{12}$

A casa foi toda estruturada com madeira sucupira em lajes e pranchas, com colunas de maçaranduba, e lajes de concreto apenas nos banheiros do segundo pavimento. Onde foram usadas paredes de alvenaria, o vigamento e o piso foram feitos com peças de madeira. A madeira foi em sua maioria trazida lavrada da mata, sofrendo cortes e acertos para preparo dos encaixes no local da obra. Os elementos vazados de concreto também foram feitos no próprio canteiro de obra. A cobertura é toda de telhas de cimento-amianto. $O$ piso do pavimento térreo é de lajotas de cerâmica e do pavimento

\footnotetext{
12 Entrevista exclusiva cedida por Severiano Porto a IAB em 1971.
} 
superior é de pranchões de madeira.

Os cômodos principais da residência se desenvolvem em torno de um grande jardim interno de pédireito duplo, vazado na parte superior, que abrange as áreas da sala e da escada. 0 pavimento superior possui um escritório e dois dormitórios. Há uma forte integração com a área externa, por meio de aberturas que a integram ao ambiente interno: "Quando tudo está aberto a casa faz parte do terreno" (PORTO, 2003; informação verbal)
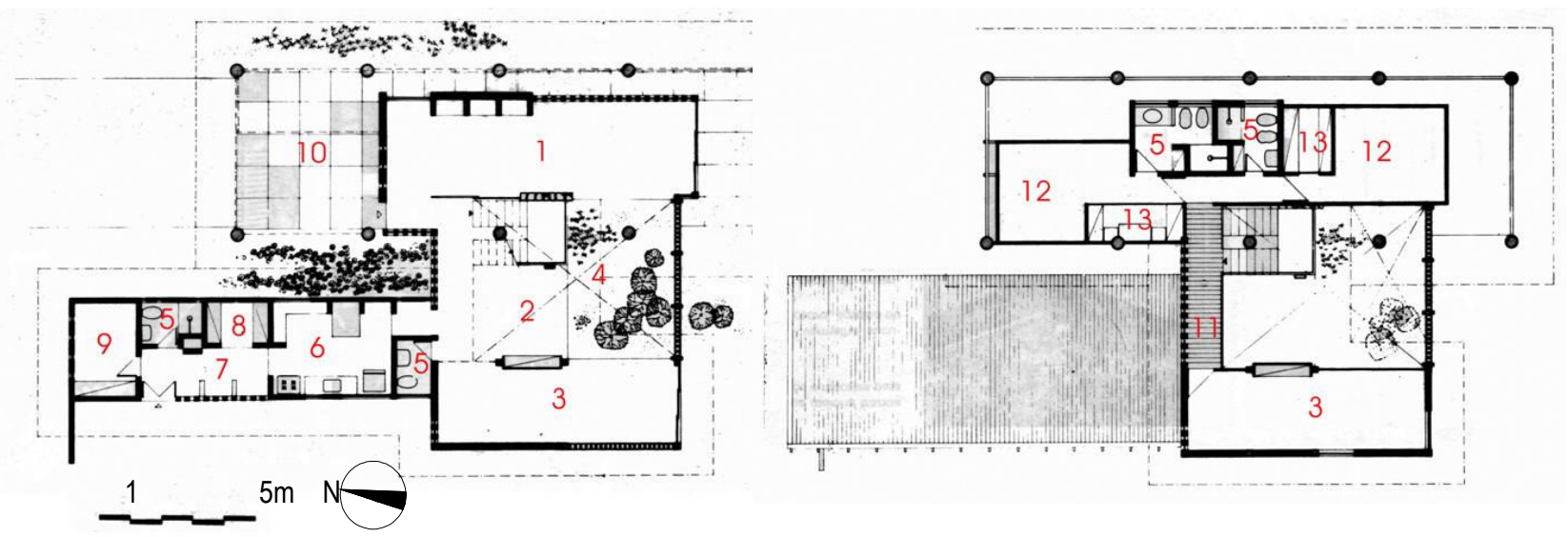

LEGENDA:

1- sala de estar

2- sala de jantar

3- varanda

4- jardim interno

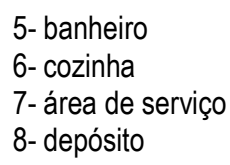

5 - banheiro

7-área de serviço

8- depósito
9- quarto de empregada 13- closet

10- garagem

11- passagem

12- dormitório

Figuras 5.5 e 5.6: Plantas dos pavimentos térreo e superior (É PRECISO, 1982)

No edifício são trabalhadas diversas soluções para adequação ao clima local, como a utilização de amplos beirais e varanda na fachada Oeste, que atenuam os efeitos da orientação desfavorável. Um painel fixo de venezianas horizontais (lambris) acima da garagem barra 0 sol e retira 0 impacto da chuva de vento, sem impedir a livre circulação do ar. Na parte inferior da cobertura, painéis treliçados, tipo muxarabi, permitem circulação de ar por todo o forro, impedindo a entrada de morcegos ou outros animais pequenos. $O$ espaço pequeno do ático prejudica a ventilação dentro dele, criando um colchão de ar quente, o que é climaticamente desaconselhável. Como compensação, o forro de madeira reduz a transmissão de calor proveniente do telhado para a área interna. 


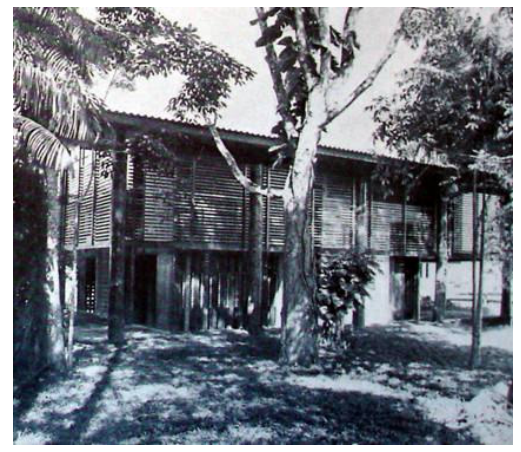

Figuras 5.7: Vista fachada Leste (CASA, 1979)
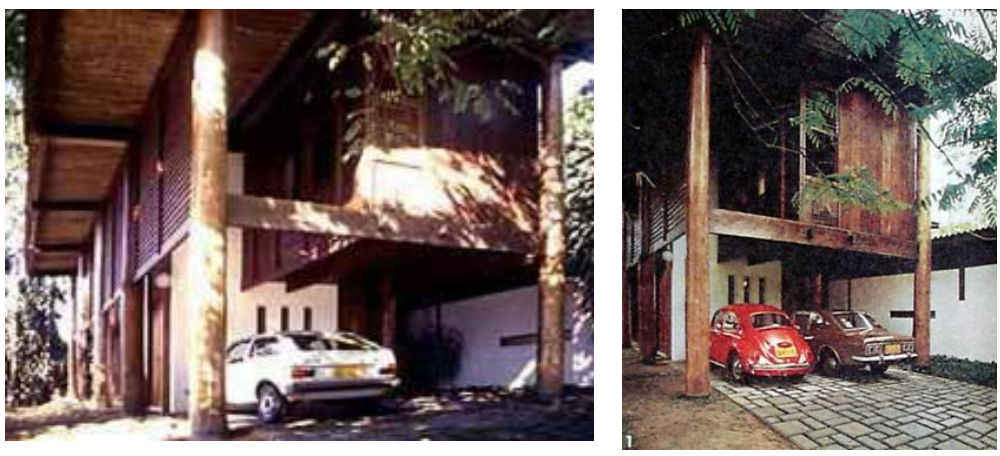

Figura 5.8 e 5.9: Vista fachada Norte

(SABBAG, 2003; BRAZIL, 1977)

O arquiteto procurou preservar o máximo possível a vegetação já existente no terreno, a fim de auxiliar na manutenção de temperaturas mais baixas de vento, tomando o devido cuidado para não barrá-lo. As árvores altas auxiliam na redução da insolação direta sobre o telhado, o que é de grande importância, já que a cobertura da residência é de telha de cimento-amianto, um material desfavorável ao clima. Esta telha sofre um enegrecimento relativamente rápido neste clima, devido à elevada umidade, o que reduz sua refletância e faz com que ela aqueça bastante com o sol, piorando o microclima interno na habitação.

Em toda a área da sala e jardim interno foram utilizados elementos vazados de concreto e rasgos verticais e horizontais com basculantes de alumínio, que visam garantir boa ventilação cruzada: "A casa está eternamente aberta e o vento circula por ela dia e noite" (PORTO, 2003; informação verbal). Também segundo o próprio arquiteto, estes basculantes permitem uma ventilação farta, já que foram empregados em bom número e em quase todas as fachadas. Nestes caixilhos, foram utilizados vidros de cor amarelo queimado, de textura rugosa, um tipo pouco adequado ao clima pois, se comparado com o vidro transparente comum, absorve e transmite mais radiação ao interior. Nos dormitórios, brises de madeira e venezianas reguláveis - mecanismos projetados pelo próprio arquiteto - permitem barrar a chuva de vento e o sol da tarde, com a possibilidade de ventilar quando houver necessidade. 


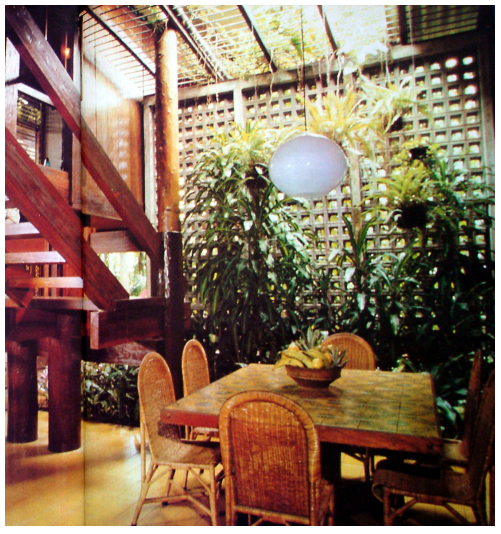

Figura 5.10: Vista interna - sala de jantar e jardim (ESTE, 1981)
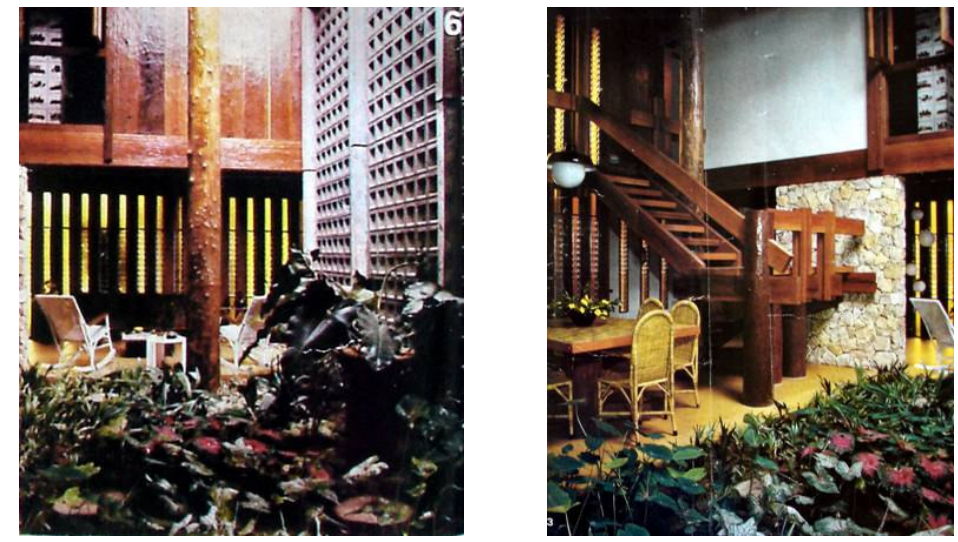

Figuras 5.11 e 5.12: Vista interna - aberturas e elementos vazados (PARA, 1972)

É importante observar as propriedades dos materiais de construção utilizados nas vedações externas e internas da residência, utilizando os conceitos de inércia térmica (termo que indica a persistência da temperatura em um material), e os fenômenos da difusividade - como se difunde a energia térmica - e efusividade - quanto se acumula de energia térmica (CORBELLA; YANNAS, 2003).

As vedações externas, feitas em madeira, são leves, apresentando, portanto, baixa inércia térmica, alta difusividade (difusão rápida da energia térmica absorvida) e baixa efusividade (baixa capacidade de armazenar calor). Isto é adequado para o clima quente e úmido, onde as temperaturas são altas e relativamente constantes durante todo o dia, devido à umidade elevada, por isso não é recomendável armazenar calor. As fachadas contribuem, portanto, para não armazenar a carga térmica recebida por incidência solar, mas sim cedê-la ao meio externo.

Já internamente, existem vedações feitas em pedra, um material com baixa difusividade (difusão lenta da energia térmica absorvida) e alta efusividade (grande capacidade de armazenar calor). Isto significa que esta vedação absorve grande parte da energia térmica existente no ar interno, o que resulta no amortecimento da variação da temperatura interna, comparada à variação externa, e na obtenção de um ambiente interno mais "fresco", já que parte da carga térmica do ar fica armazenada. Por isso, este material pode ser adequado para vedações internas em clima quente e úmido.

A residência chegou a ser premiada pelo $I A B$, por utilizar a madeira de uma maneira adequada, de acordo com o clima e o meio ambiente, tornando-se um exemplo de arquitetura harmoniosamente inserida no contexto regional: "excelente proposta do autor, coerente, elaborada com vocabulário brasileiro [...] sem se alienar da técnica contemporânea." (CAMPOS, 2003). Porto vendeu sua 
residência quando deixou Manaus; ela foi desmontada em 2003 e suas peças guardadas para ser remontada em outro local, com a intenção de ser sede do IAB, segundo informações fornecidas pelo arquiteto (PORTO, 2005; informação verbal).

\subsubsection{Banco da Amazônia, 1974}

Ao defender a escolha do sistema construtivo de acordo com as condicionantes locais, Porto critica a proliferação de prédios suntuosos para as redes bancárias, que destoam da arquitetura local e causam um certo desequilíbrio (PORTO, 2003; informação verbal). Em vista disso, o projeto do banco da Amazônia procurou integrar-se à arquitetura local.

O projeto para o banco tinha a intenção de demonstrar, através da arquitetura, as principais finalidades do banco - de incentivo ao desenvolvimento regional e integração à realidade local - 0 que levou ao uso de madeira da região, resultando em um edifício que não agride, mas integra-se ao meio, tanto pelo aspecto formal quanto estrutural e tecnológico. Minga (1990) reforça este aspecto ao comentar sobre o edifício: "No lejos del famoso Teatro Amazonas, contrasta con esa arquitectura por un enfoque de 'adentro hacia fuera', donde la fachada resulta de una decisión estructural y bio-climática." (MINGA, 1990)
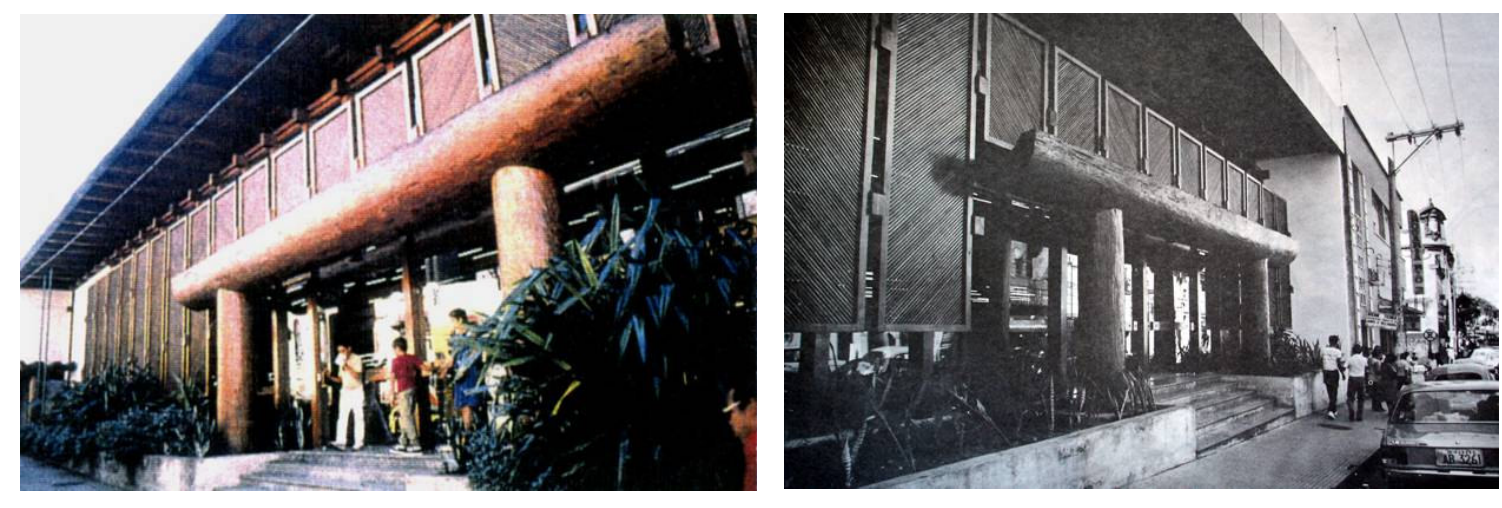

Figuras 5.13 e 5.14: Vista fachada principal (LEE, 1998; INSTITUTO DE ARQUITETOS DO BRASIL, 1984)

O sistema construtivo baseia-se em um misto de concreto e madeira. Na fachada principal foram usadas peças de madeira de grandes bitolas, com seus troncos em sua textura e forma originais. No interior há utilização de concreto para estrutura das lajes, e nas áreas de caixa forte, segurança, sprinkler, etc., o que mostra uma adequação do material construtivo ao programa. A madeira é utilizada 
integrando-se ao concreto, através de tipos e seções variados. Internamente, o ambiente é inteiramente livre, o que proporciona um espaço amplo. A entrada principal possui pé-direito duplo e um grande mezanino abriga as funções de gerência e expediente (PENTEADO et al, 1986).
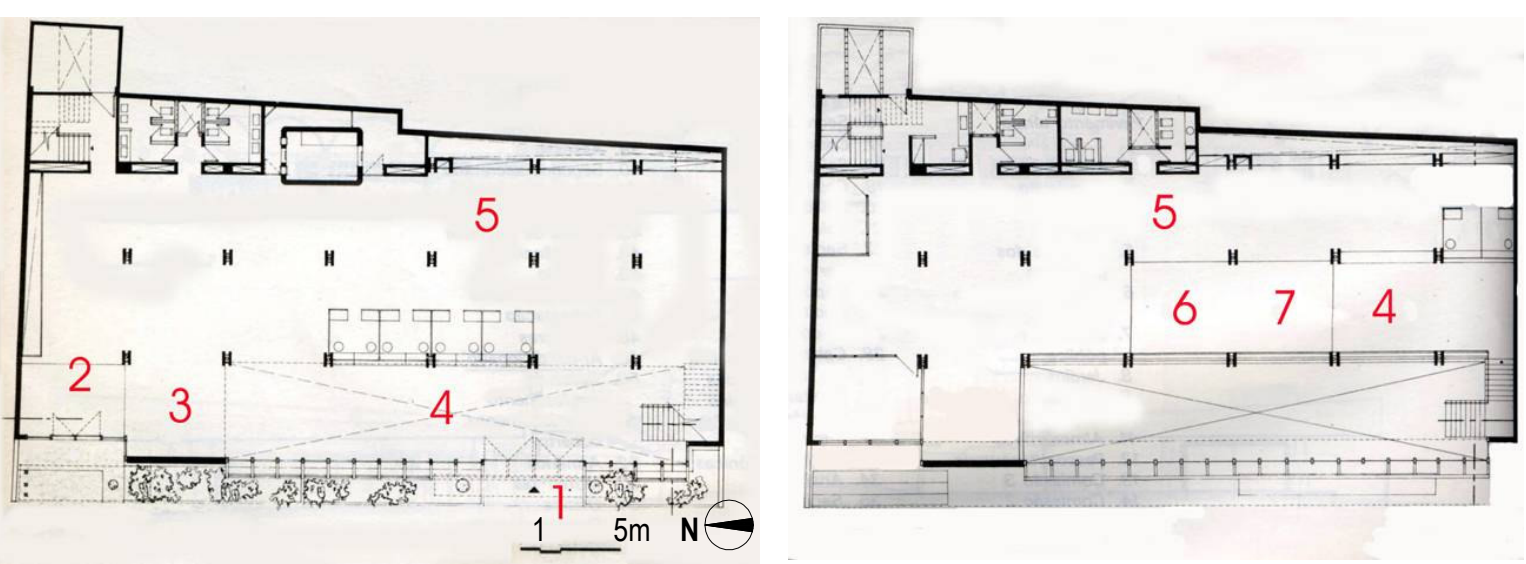

LEGENDA:
1- Entrada
3- Subgerente
5- Expediente
7- Recepção
2- Portaria
4- Público
6- Gerência

Figuras 5.15 e 5.16: Plantas térreo e pavimento superior (PENTEADO et al, 1986)

$\mathrm{Na}$ fachada principal, que é de orientação Oeste, são utilizados grandes painéis de treliça em madeira (tipo muxarabi) que protegem contra a radiação solar e reduzem a luminosidade interna, sem impedir a visão do interior para o exterior. Estes painéis compõem um elemento que proporciona maior conforto térmico, ao mesmo tempo em que dá forte plasticidade no conjunto. Na parte superior da fachada há um painel de fibra com compensado de $20 \mathrm{~mm}$, que também auxilia na proteção da radiação solar. Internamente, trilhos para colocação de luminárias permitem um livre layout da iluminação, de acordo com a necessidade.
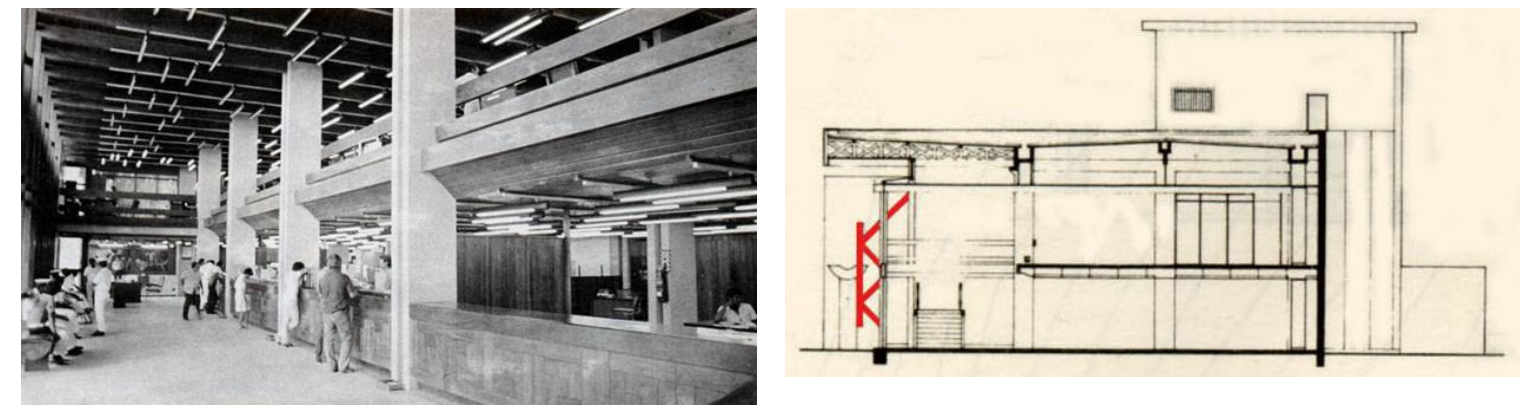

Figura 5.17: Vista interna (PENTEADO et al, 1986) Figura 5.18: Corte transversal - detalhe da treliça em destaque (PENTEADO et al, 1986) 


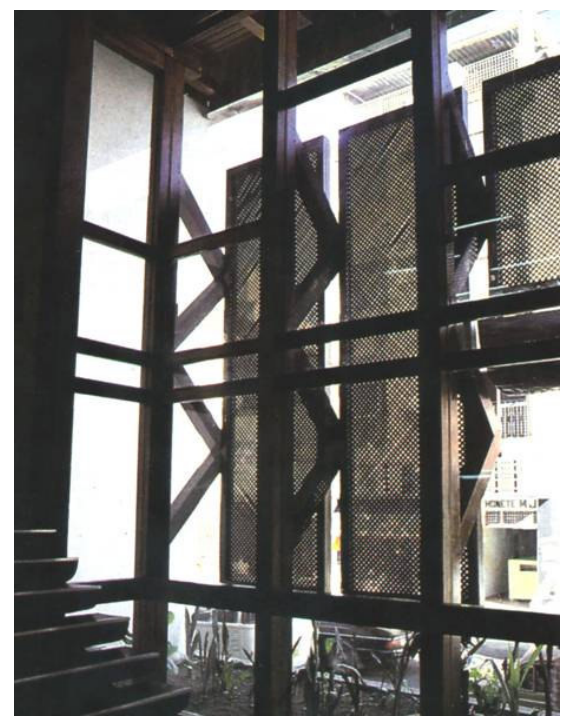

Figura 5.19: Painéis de treliça da fachada Oeste (PENTEADO et al, 1986)

\subsubsection{Residência Robert Schuster, 1978}

Robert Schuster, um topógrafo austríaco, trabalhou durante vários anos com Severiano Porto, de quem era grande amigo. Para o projeto de sua residência, escolheu um terreno em um loteamento rural, com grandes áreas ainda de vegetação densa e fechada de floresta, próximo ao igarapé de Tarumã Açu, na cidade de Manaus. $O$ terreno destinado à construção possuía árvores altas, em grande quantidade e próximas umas às outras, o que resultava em um ambiente bastante sombrio, em que o sol quase não atingia o solo. Esta premissa direcionou o partido arquitetônico adotado para o projeto, que consistia em estar atento às condições climáticas locais e preservar ao máximo a vegetação original existente no terreno. Por isso, a habitação se eleva do solo, permitindo uma melhor ventilação e reduzindo a retirada de vegetação.

A casa foi construída em vários níveis, já que a solução vertical reduziria ao mínimo a área destinada à construção, permitindo maior conservação da floresta original. Os diversos níveis ocorrem em torno de um grande vazio central coberto, que promove uma circulação integrada de todos os ambientes e permite que o vento circule livremente por todo o interior. 

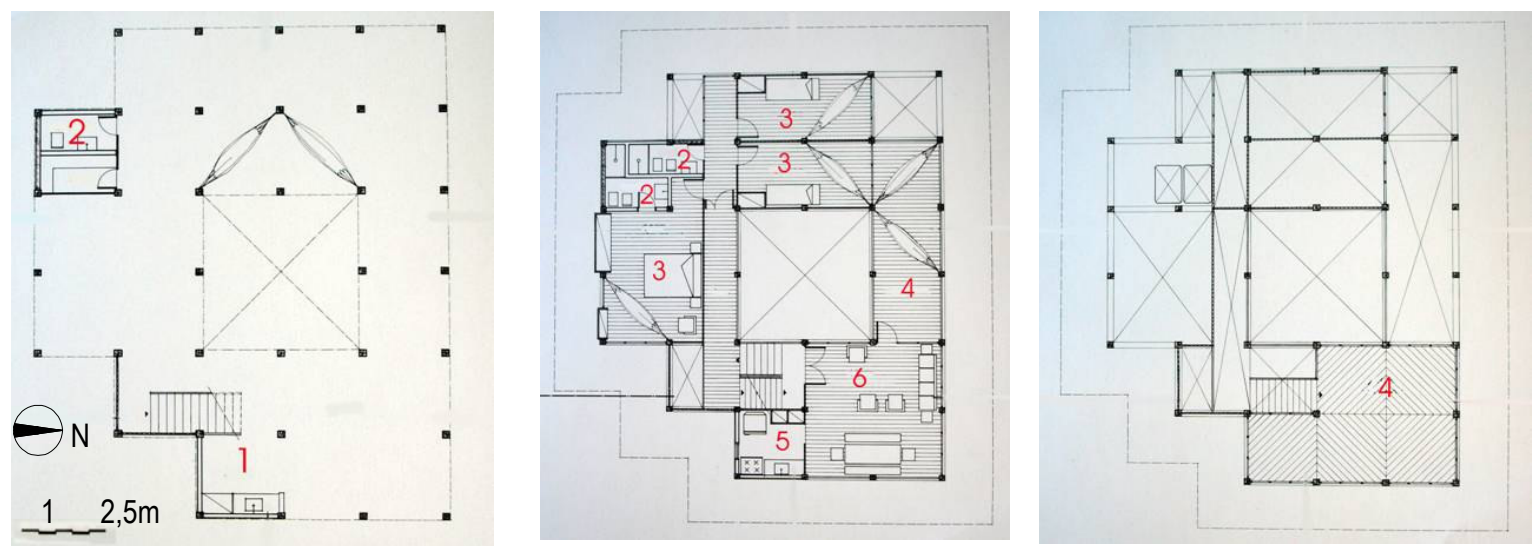

LEGENDA:
1- copa
3- quarto
5- cozinha
2- banheiro
4- varanda
6- sala de estar/ jantar

Figuras 5.20 a 5.22: Planta nível 0.00; planta níveis +2.20 a +3.10 ; planta nível +5.30 (acervo NPD-

UFRJ)

A casa apresenta um grande cuidado com a ventilação natural, estratégia essencial para o bom desempenho térmico de uma construção em clima quente e úmido e preocupação sempre presente nas obras do arquiteto. Como a edificação está dentro da floresta, os problemas trazidos pela radiação solar ficam amenizados, já que a vegetação protege a construção. Porém esta situação prejudica a ventilação, pois a floresta reduz a velocidade dos ventos dominantes, além de aumentar a umidade. Por isso, o vazio central contínuo, sem paredes, permite que a casa seja inteiramente aberta ao vento, como afirma 0 arquiteto: "Nessa casa era tudo aberto [...] o vento passava pra lá e pra cá, tranqüilo." (PORTO, 2005; informação verbal)

A grande quantidade de portas, janelas e vedações de muxarabi contribuem para que o espaço interno esteja sempre bem ventilado; esquadrias de venezianas móveis regulam e direcionam o fluxo de ar, que percorre toda a estrutura da casa. Porto (2005) comenta que o próprio Schuster, durante a construção da residência, não quis que fosse colocado fechamento na parte superior, próxima ao telhado, valorizando o conforto trazido pela ventilação e não se importando com os bichos que poderiam entrar (informação verbal). $O$ forro, em diversos níveis, está sempre a uma distância razoável do telhado, permitindo um grande espaço ao ático, que é aberto e deixa passar o vento constantemente. 

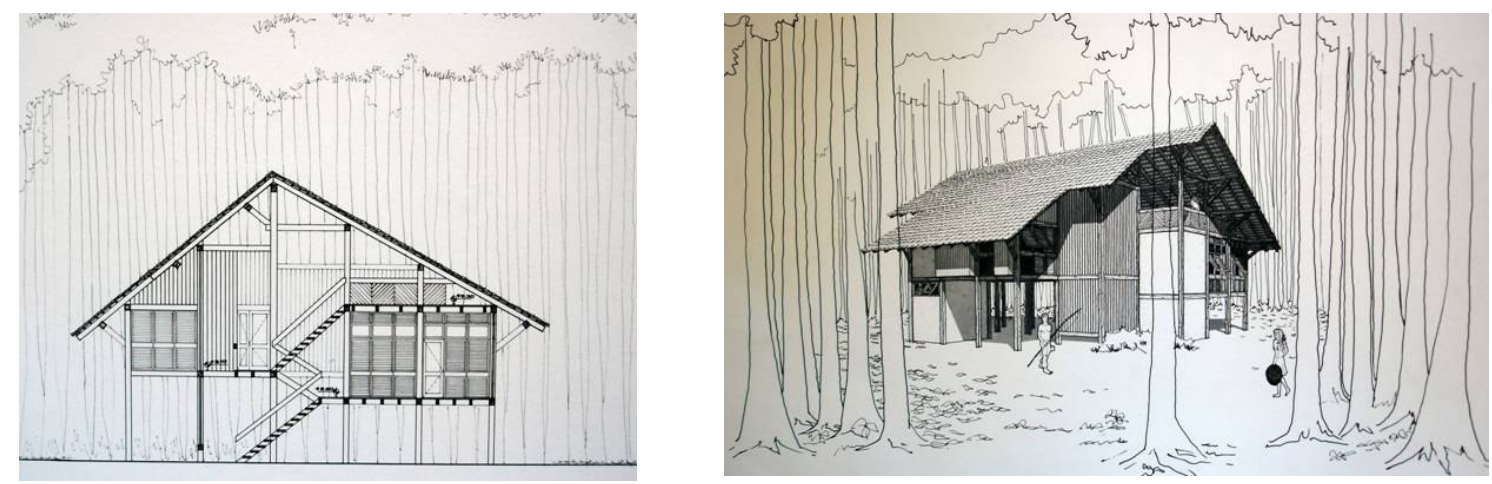

Figuras 5.23 e 5.24: Corte passando pela sala e escada; perspectiva (acervo NPD-UFRJ)

A estrutura da residência é toda em madeira lavrada da região, a cobertura é em cavaco com juntas ventiladas, que também contribuem na ventilação. Beirais amplos protegem da chuva, sem bloquear 0 vento. $O$ resultado obtido é de um edifício em harmonia com o entorno, que valoriza os materiais e técnicas construtivas encontrados na região, e atende às necessidades locais com soluções simples e integradas à natureza. "Esta edificação mostra a possibilidade de uma construção dentro da densa floresta amazônica, plenamente adequada ao meio, sem alterar-lhe o equilíbrio ecológico." (CASTRO FILHO, 1984). A residência foi vencedora do prêmio do IAB em 1978 na categoria 'Projeto de habitação unifamiliar'.

\subsubsection{Ambulatório médico do IPASEA, 1979}

Para o projeto do ambulatório médico do Instituto de Aposentadoria e Pensão do Estado do Amazonas (IPASEA), o arquiteto buscou por uma solução adequada ao clima local, apesar das condições desfavoráveis do terreno - a fachada principal fica para Oeste. O projeto exigia que houvesse pouca necessidade de manutenção, sem que isto afetasse as necessidades de funcionamento, por isso o material escolhido para a construção foi o concreto armado. $O$ uso de refrigeração artificial procurou ser reduzido ao máximo, sendo instalado apenas nos ambientes onde seria indispensável.

As circulações para usuários, funcionários e médicos são independentes, sendo que as circulações de usuários e salas de espera situam-se perifericamente, em varandas. Além dos consultórios, o edifício possui espaços administrativos, biblioteca e auditório, divididos em três pavimentos. 


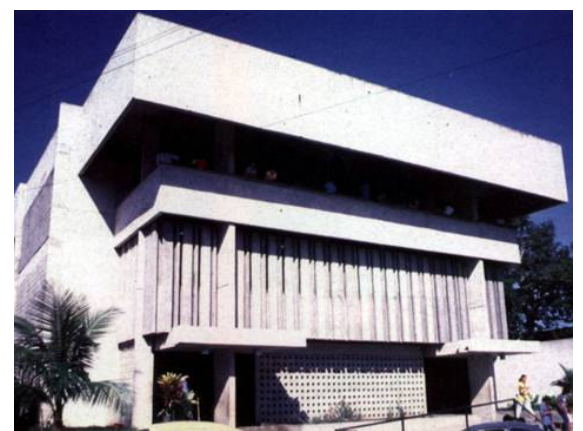

Figura 5.25: Vista fachada Oeste entrada principal (HESPANHA, 2005)

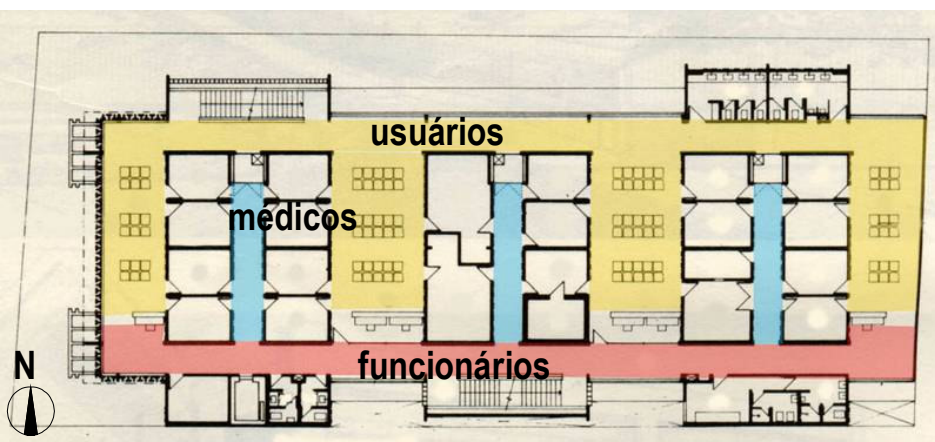

Figura 5.26: Planta primeiro pavimento, indicando circulações independentes (PENTEADO et al, 1986)

Na edificação houve a integração do projeto de climatização natural com o projeto de climatização por sistema mecânico, isto é, o uso de ar condicionado procurou restringir-se aos ambientes estritamente necessários, e a ventilação natural foi trabalhada com o intuito de garantir conforto térmico aos espaços onde não há uso do ar, bem como auxiliar na climatização de todo o edifício, reduzindo os gastos com energia e ampliando a eficiência energética da construção. Porém, o material escolhido para a construção - concreto aparente - não é adequado para o conforto térmico, por ser um material de inércia térmica elevada, que contribui para o armazenamento de calor e aquecimento do ambiente interno.

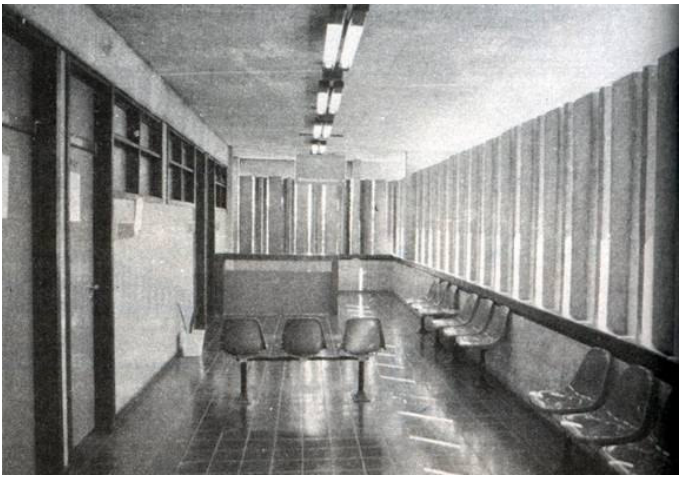

Figura 5.27: Sala de espera na fachada Oeste (PENTEADO et al, 1986)

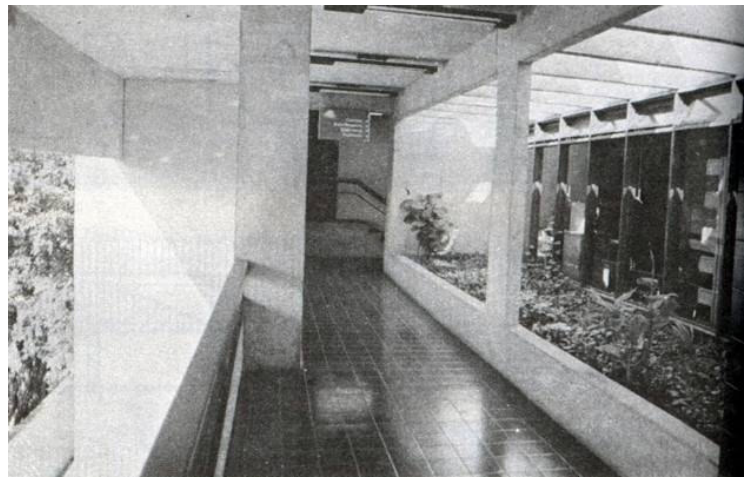

Figura 5.28: Circulação de usuários (PENTEADO et al, 1986)

A fachada principal, por ser orientada para o Oeste, possui um beiral amplo, elementos vazados de 
concreto e brises verticais em forma de $\mathrm{T}$, que amenizam a incidência solar no período da tarde e permitem a ventilação cruzada nas circulações e salas de espera.

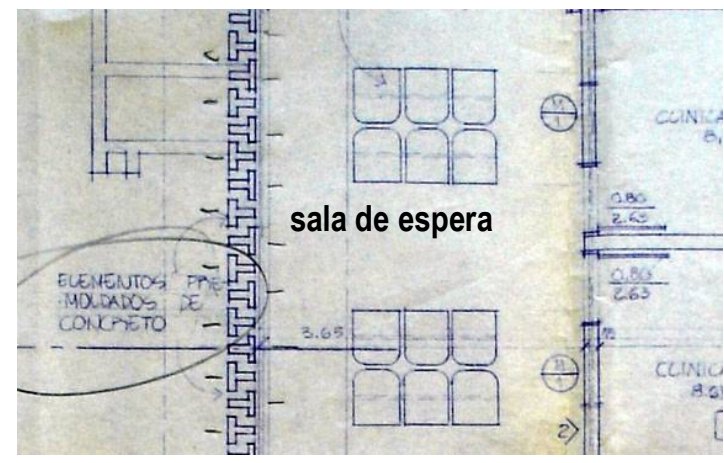

Figura 5.29: Detalhes dos brises verticais em forma de T - planta $1^{\circ}$ pavimento (acervo NPD-UFRJ)

\subsubsection{Centro de Proteção Ambiental de Balbina, Presidente Figueiredo, 1983-88}

O Centro de Proteção Ambiental da Usina Hidrelétrica de Balbina situa-se no município de Presidente Figueiredo, a $180 \mathrm{~km}$ de Manaus. É importante citá-la, neste contexto de estudo, pelo caráter excepcional que representa para a arquitetura brasileira, por ser considerada uma obra em que o caráter regional atingiu um refinamento, sendo a madeira trabalhada de maneira singular, tanto no aspecto formal quanto estrutural.

... El Centro de Protección Ambiental de la represa de Balbina (Amazonas) es la síntesis de un proceso de casi 20 años. ...Un partido perfectamente adaptado al sistema constructivo, que permitió (por relación de cubiertas/ pisos, ideal para condiciones cálido húmedas) una total libertad de creación. ...el área de una gran cubierta contínua se trabaja de manera diferenciada en formas, alturas, dimensiones... la obra misma es una investigación de maderas posibles en la biodiversidad del bosque amazónico. (MINGA, 1990)

Balbina é uma usina hidrelétrica que foi construída no interior do Amazonas na década de 80, quando Porto foi requisitado a fazer o projeto de um centro de proteção ambiental, que seria responsável em realizar a avaliação de impacto ambiental da região causado pelo empreendimento. Como a área seria alagada devido à construção da usina, o arquiteto recebeu a liberdade de usar a madeira que quisesse, da forma que desejasse. O programa incluía todo o aparato necessário a um centro de pesquisa, com laboratórios, espaços para coleta de dados e áreas para alojamento (PORTO; RIBEIRO, 1989). 0 
conjunto foi construído parcialmente - apenas a área destinada a laboratórios, que hoje praticamente não funcionam - e o centro é mais utilizado para visitação e atividades de turismo.

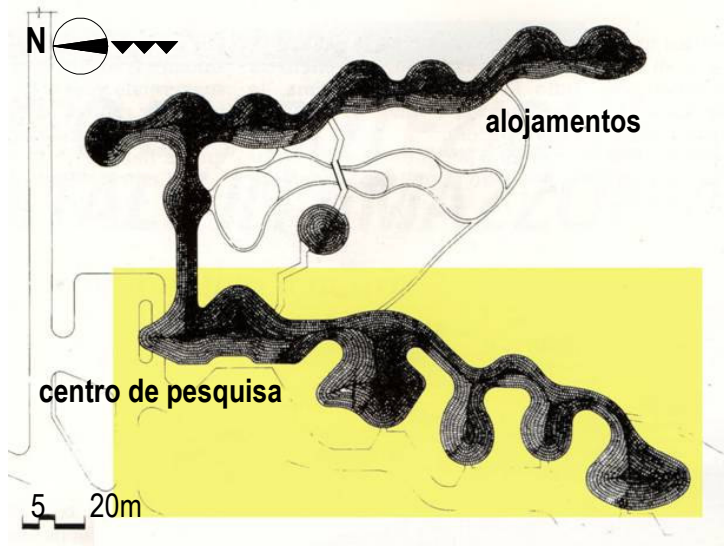

Figura 5.30: Cobertura - indicação da área construída em destaque (SEGAWA, 1991)

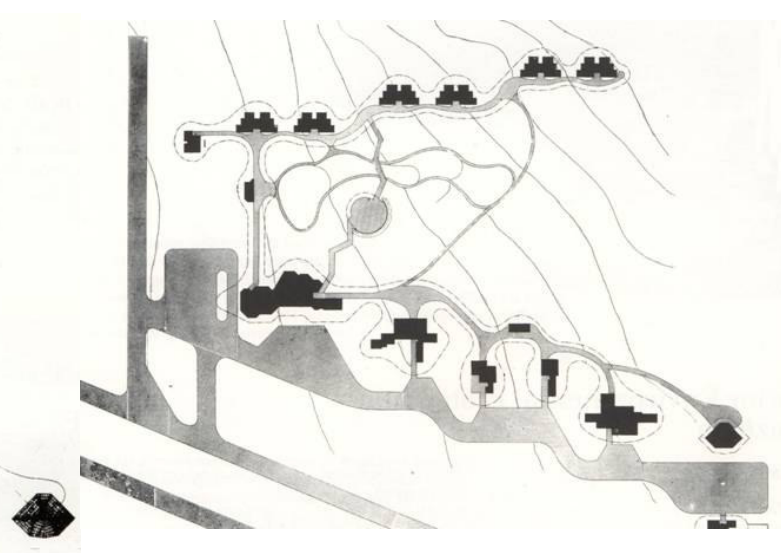

Figura 5.31: Implantação geral (SEGAWA, 1991)

Nesta obra, o arquiteto trabalhou a madeira de uma forma completamente livre, utilizando-a de diferentes maneiras: troncos roliços, vigas e pilares de seção retangular, tábuas e caibros de madeiras beneficiadas (LEE, 1998). O cavaco foi utilizado na cobertura; material que, segundo Porto (2003), dá uma liberdade muito grande, pois pode ser trabalhado da forma que se desejar, fazendo a curva que se quiser, ao contrário da telha plana, que possui uma certa rigidez (informação verbal). A cobertura em cavaco foi uma solução que ele passou a utilizar depois de experimentar outros materiais, e observar as vantagens deste. A palha, inicialmente muito usada por Severiano, apesar de ser um material que também dá uma grande liberdade formal, possui a desvantagem de ter um tempo de vida útil curto, devendo ser trocada periodicamente. Uma fábrica de cavaco foi montada especialmente para esta obra, garantindo uma produção e um assentamento impecáveis.

O edifício foi implantado de forma a se adaptar à declividade natural do terreno, de acordo com os ventos dominantes da região, que são Leste-Oeste, diferentemente de Manaus. Os ambientes estão em diversos níveis, interligados por passarelas. Uma grande cobertura abrange toda a extensão da edificação, em solução equivalente à utilizada na Universidade do Amazonas, onde os espaços se organizam de forma independente sob ela. Entre esta cobertura e os ambientes fechados há um colchão de ar ventilado, que chega a atingir até oito metros de altura, e contribui na melhoria do conforto térmico interno. 


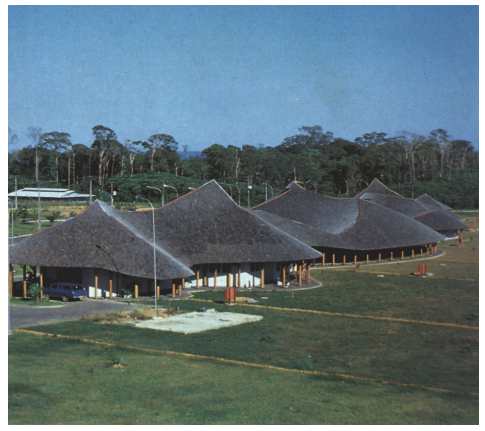

Figura 5.32: Vista geral

(PORTO; RIBEIRO, 1989)
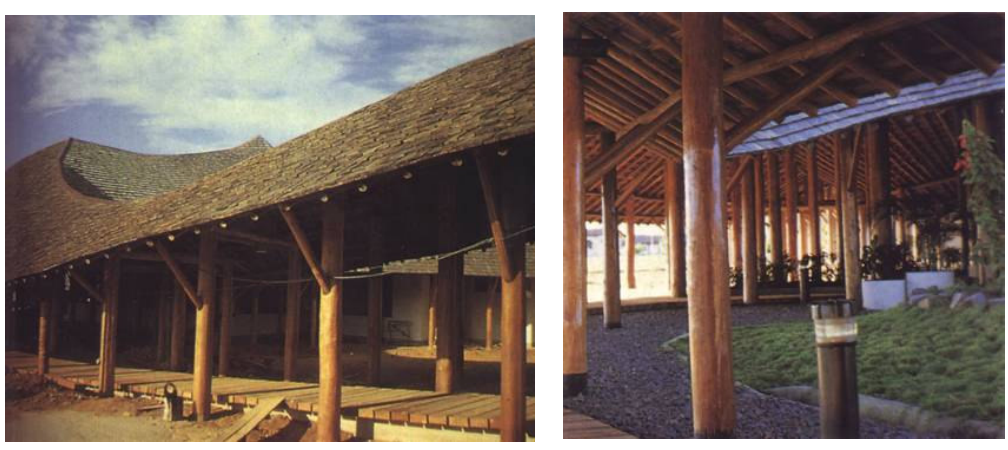

Figuras 5.33 e 5.34: Cobertura e circulação

(PORTO; RIBEIRO, 1989)

\subsection{IMPORTÂNCIA DO ARQUITETO NO CONTEXTO DE ESTUDO}

Severiano Porto é um arquiteto sempre lembrado pelas publicações encontradas por possuir uma arquitetura que valoriza a relação da construção com o sítio e trabalha soluções passivas para obtenção de conforto ambiental. Soluções de caráter bioclimático se destacam em seus projetos e são frequentemente mencionados pela crítica: "Em todos os trabalhos deixou evidente a preocupação em contextualizar a obra de acordo com as necessidades do entorno." (SILVA, 2004).

A partir dos dados levantados, constata-se a relevância da produção de uma arquitetura identificada ao meio, que leve em conta as condições climáticas da região, aplique os conceitos da arquitetura bioclimática e contribua para reduzir o consumo de energia. A adoção de tal concepção arquitetônica, além de tudo, visa a satisfação das exigências de conforto dos usuários através do uso de estratégias passivas de condicionamento. Dentre estas, as estratégias de ventilação natural são de fundamental relevância para o clima quente e úmido.

As soluções propostas nas obras de Severiano Porto expressam sua procura em adequar-se ao contexto local - construções, em sua grande maioria, da década de 70 , que se destacam pela qualidade pouco observada na grande maioria das construções da região e que servem como exemplo até os dias atuais. Segundo John (2004), a tecnologia de construção da Amazônia até hoje ainda é inadequada ao clima e aos materiais disponíveis na região (informação verbal) ${ }^{13}$. A arquitetura bioclimática, portanto, é um caminho a ser seguido não só para prover conforto térmico aos usuários,

\footnotetext{
13 Informação fornecida por Vanderley M. John, professor associado da Escola Politécnica da Universidade de São Paulo, em palestra proferida no claCS, ENTAC 2004, intitulada "Seleção de materiais e componentes com base em critérios de sustentabilidade", no dia 21/07/2004.
} 
mas para incentivo à produção de uma arquitetura menos agressora e mais harmoniosamente inserida no local.

A importância de Severiano Porto, neste contexto de estudo, consiste no uso adequado dos materiais e tecnologias disponíveis e na busca de adequação ao contexto e clima locais. 0 trabalho cuidadoso nos aspectos de conforto ambiental e em especial às estratégias de ventilação natural, através da proposição de soluções simples e criativas, procura integrar melhor suas obras ao clima e reduzir o uso de sistemas mecânicos de climatização, o que resulta em uma arquitetura de maior eficiência energética e com forte presença de aspectos bioclimáticos.

As obras apresentadas e discutidas no item anterior representam uma parcela da produção do arquiteto Severiano Porto. Mostram, de uma maneira geral, o que foi seu trabalho na região amazônica, quais foram os caminhos que o guiaram e as intenções projetuais que o acompanharam: a abordagem regional de sua arquitetura, a intenção em se adaptar à cultura e ao clima locais, a liberdade no uso dos materiais. Como desenvolvimento desta pesquisa, empreende-se uma análise mais detalhada de três obras do arquiteto (que serão apresentadas nos capítulos seguintes), escolhidas no decorrer do processo de levantamento de material sobre sua produção e revisão bibliográfica. 


\section{MATERIAIS E MÉTODOS}

Após a revisão bibliográfica, que dá uma abordagem geral sobre o tema de pesquisa proposto, são apresentados aqui os procedimentos metodológicos que nortearam o desenvolvimento da presente pesquisa. Um fator indispensável para sua realização foi o apoio financeiro concedido pelo projeto de auxílio à pesquisa FAPESP intitulado "Arquitetura bioclimática e a obra de Severiano Porto". O projeto, desenvolvido sob coordenação da professora Rosana Caram, teve como objetivo dar subsídios ao desenvolvimento desta pesquisa, equipando o laboratório de Conforto Ambiental do Departamento de Arquitetura e Urbanismo da Escola de Engenharia de São Carlos-USP e financiando as viagens necessárias para levantamento de dados e pesquisa de campo.

Em um primeiro momento, foi realizado um levantamento geral da vida e obra de Severiano Porto, apresentados na revisão bibliográfica, que deu base à escolha de três obras do arquiteto. Em seguida, os três edifícios selecionados foram analisados mais detalhadamente, quanto às estratégias de ventilação natural apresentadas e outros aspectos bioclimáticos relacionados. Esta análise foi realizada através de dados obtidos tanto nos projetos originais como em visita às obras para pesquisa de campo. Desta forma, o desenvolvimento da pesquisa baseou-se nas seguintes etapas: levantamento de dados, análise qualitativa e descritiva, análise quantitativa e análise dos resultados - que serão detalhadas a seguir.

\subsection{LEVANTAMENTO DE DADOS}

Esta etapa consistiu no levantamento de material sobre o arquiteto Severiano Porto e seus projetos realizados na cidade de Manaus-AM, através da pesquisa em publicações existentes e da consulta ao acervo do Núcleo de Pesquisa e Documentação da Universidade Federal do Rio de Janeiro (NPDUFRJ). Este acervo contém material doado pelo arquiteto à Universidade, que consiste em cerca de 1200 pastas, contendo originais e cópias de mais de 250 projetos desenvolvidos por seu escritório, desde estudos preliminares até pranchas de projeto executivo; além de cerca de 50 volumes de periódicos.

A pesquisa foi feita através de uma viagem ao Rio de Janeiro, realizada na semana de 28 de março a primeiro de abril de 2005, onde o material do NPD foi consultado e fotografado, resultando em um total de 436 imagens de doze projetos de Porto. São eles: Aldeias Infantis SOS Brasil, banco da Amazônia, 
Centro de Proteção Ambiental de Balbina, residência Robert Schuster, Superintendência da Zona Franca de Manaus, residência do arquiteto, Universidade do Amazonas, residência Alexandre Ale dos Santos, pousada na llha de Silves, ambulatório médico do IPASEA, restaurante Chapéu de Palha e edifício Aracoara (ver anexo 13.2).

Durante esta viagem também foi realizada uma entrevista com o arquiteto (dia 30 de março de 2005), cuja transcrição encontra-se no anexo 13.1. Foram abordados tópicos acerca do processo de definição e desenvolvimento de seu trabalho na região amazônica, e mais especificamente das obras construídas em Manaus. Foi questionado em quais obras, para ele, os aspectos de conforto ambiental e ventilação natural foram melhor trabalhados, e em que estado de conservação estas obras encontram-se atualmente; o que serviu como base para a análise qualitativa.

Também fez parte desta etapa a transcrição do curso 'Arquitetura, Estrutura e Construção', ministrado por Severiano Porto no período de 01 a 04 de julho de 2003, na EESC-USP, onde 0 arquiteto apresentou boa parte de sua produção e explicou sobre seu processo projetual.

Como resultado deste levantamento, foram escolhidas três obras do arquiteto, consideradas significativas para a realização deste estudo, para uma análise mais detalhada quanto à ventilação natural.

\subsection{ANÁLISE QUALITATIVA E DESCRITIVA}

Uma primeira análise das três obras selecionadas teve uma abordagem essencialmente qualitativa/ descritiva, centrada em leitura de projeto sobre o material obtido no levantamento de dados e complementada por algumas informações obtidas pela pesquisa de campo e pelo levantamento fotográfico empreendido; sendo utilizadas como base para discussão as recomendações obtidas na literatura especializada consultada.

Esta etapa destacou as soluções de ventilação natural propostas por Severiano, através do desenho e caracterização dos sistemas encontrados, análise de seu funcionamento e da distribuição interna do fluxo de ar. As imagens digitalizadas obtidas no NPD foram utilizadas como base para o redesenho de plantas, cortes, fachadas e detalhes construtivos, o que garantiu uma leitura de projeto mais aprofundada com relação às estratégias de ventilação natural adotadas.

Houve, primeiramente, uma avaliação do microclima em que cada obra está inserida, através do estudo da topografia e implantação, da exposição do edifício ao sol e aos ventos, das possíveis obstruções 
existentes no entorno, do tratamento dado aos espaços abertos e às áreas verdes; aspectos estes que influem no desempenho da ventilação natural e do conforto térmico da edificação. Posteriormente, houve a caracterização dos sistemas de ventilação encontrados, feita através de análise descritiva da ventilação natural por ação dos ventos (ventilação cruzada) e por diferença de temperatura (efeito chaminé), onde os principais fatores observados foram a disposição dos espaços abertos próximos; presença de obstáculos no entorno; orientação, forma e geometria do edifício; dimensão, posicionamento e tipo das aberturas de entrada e saída de ar; subdivisões do espaço interno.

\subsection{ANÁLISE QUANTITATIVA}

Esta etapa consistiu em pesquisa de campo para visita às três obras escolhidas na cidade de Manaus, através de viagem realizada no período de 22 de janeiro a 15 de fevereiro de 2006 . Foram efetuadas medições climáticas de três fatores ambientais que influem na sensação de conforto térmico: temperatura de bulbo seco (TBS), umidade relativa e velocidade do ar, durante uma semana em cada obra; além da realização de registros fotográficos, croquis, levantamento do estado de conservação atual das obras e eventuais reformas e modificações.

Para a medição das variáveis térmicas temperatura e umidade relativa do ar foram utilizados cinco equipamentos HOBO RH/Temp. Estes aparelhos precisam ser protegidos da radiação solar para que não haja interferência nas medições, por isso foram colocados dentro de latas de alumínio polido (material de baixa emissividade), com furos nas laterais para circulação do ar. Além disso, durante as medições eles sempre foram dispostos em pontos protegidos da radiação solar direta. Os equipamentos foram previamente testados antes de serem utilizados na pesquisa.

As medições foram realizadas interna e externamente aos edifícios, em intervalos de 15 minutos, durante uma semana em cada obra, resultando em cerca de 672 leituras em cada ambiente no total (o equipamento tem capacidade de armazenar até 7944 leituras). Após esse período, os dados foram descarregados em um computador, conferidos e armazenados.

Para a medição da velocidade do ar foi utilizado o confortímetro SENSU, equipamento fabricado pelo Laboratório de Meios Porosos e Propriedades Termofísicas da Universidade Federal de Santa Catarina (LMPT-UFSC). O equipamento é capaz de medir as variáveis temperatura de bulbo seco, umidade relativa, velocidade do ar e temperatura de globo, e possui sistema de armazenamento de dados.

Como a velocidade e direção do vento são dados variáveis, a ventilação por meios naturais em um 
edifício também varia a todo momento. Portanto, não há como fazer medições em um único ponto representativo do ambiente, mas sim em diversos pontos simultaneamente. Por isso, o confortímetro foi equipado com quatro anemômetros extras (além do sensor que já vem acoplado à base), que captam a velocidade do ar no intervalo de 0,05 a 3m/s. Assim, foram dispostos alguns pontos de medição em locais estratégicos dos ambientes internos e um ponto externamente, durante cinco dias em cada obra, em diferentes períodos do dia, com o objetivo de registrar as características predominantes do vento, através de medições em horários e posições variadas. Com isso, pôde-se realizar uma avaliação quantitativa da contribuição proporcionada pela ventilação natural para o desempenho térmico dos edifícios analisados.

As medições foram realizadas em intervalos de cinco minutos, em diferentes períodos do dia, por cerca de uma a duas horas. Os pontos de medição no ambiente interno foram dispostos dentro da zona de atividade dos usuários do espaço, a $1 \mathrm{~m}$ ou $1,2 \mathrm{~m}$ de distância do piso. Diferentes ambientes foram escolhidos em cada obra para a realização destas medições, dependendo da disponibilidade do momento.

Para a realização da pesquisa de campo, os órgãos responsáveis pela administração dos edifícios escolhidos para análise foram previamente contatados, para a solicitação de permissão para a realização da pesquisa. Na Universidade do Amazonas (UFAM), a reitoria do campus foi contatada, que indicou o professor Nelson Kuwahara, da Faculdade de Tecnologia, como responsável pelo acompanhamento e auxílio no desenvolvimento do trabalho. Na Suframa, foi contatada a coordenadora Auxiliadora Tupinambá, que indicou a divisão de administração dos distritos e o engenheiro Roberto de Almeida Moraes para acompanhamento na realização do levantamento. Nas Aldeias Infantis, a coordenadora geral do conjunto indicou a mãe Lúcia, que gentilmente se dispôs a ceder sua casa-lar para a realização da pesquisa.

Após o monitoramento das três obras, foram elaborados gráficos comparativos, cuja leitura foi realizada em duas etapas: dados obtidos para temperatura e umidade, em que houve uma comparação quantitativa entre o ambiente interno e o externo; e dados obtidos para velocidade do ar, em que foram analisadas as diferenças entre a velocidade do vento interna e a velocidade do vento livre disponível no exterior.

\subsection{ANÁLISE DOS RESULTADOS}

A análise de resultados consistiu em uma avaliação de desempenho térmico e ventilação natural das 
obras, realizada através de discussão e comparação dos dados obtidos nas análises qualitativa e quantitativa. Nesta etapa, foi avaliada qual a real eficácia das estratégias de ventilação natural propostas por Severiano Porto nas obras analisadas, a fim de definir quais os recursos disponíveis para otimizar a ventilação e indicar propostas de adaptações e melhorias. Assim, pôde-se identificar a real contribuição de tais estratégias para o conforto ambiental interno nos edifícios estudados.

Para interpretação dos dados de temperatura e umidade, houve a aplicação conjunta de dois métodos, que serviram como base para a análise empreendida: o método de Mahoney e a ASHRAE Standard 55-2004. A aplicação das planilhas Mahoney resultou na obtenção de algumas diretrizes de projeto, tanto arquitetônicas quanto urbanísticas, para o município de Manaus. Estas diretrizes auxiliaram na análise das obras de Severiano Porto, fornecendo subsídios para avaliação de aspectos de implantação, adequabilidade dos materiais construtivos utilizados na construção e aberturas para ventilação. Juntamente com este método, foi aplicada a ANSI/ASHRAE Standard 55-2004, critério estabelecido pela ASHRAE para determinar intervalos de temperatura interna aceitáveis, de acordo com a média mensal de temperatura externa de um determinado local. Este modelo para determinação de zonas de conforto é resultado de uma pesquisa minuciosa realizada em âmbito global e permitiu verificar, através de parâmetros atuais, se os ambientes monitorados encontravam-se dentro de um intervalo aceitável de temperatura.

Para análise dos dados de velocidade do ar, além da avaliação com base nas diretrizes básicas fornecidas pelo método de Mahoney, foram utilizados como parâmetros alguns dados obtidos em literatura especializada sobre ventilação natural, dos seguintes autores: Givoni (1976), Olgyay (1998), Evans (1957), Borel (1967). Este procedimento permitiu obter indicações sobre velocidades de ar recomendáveis, seus efeitos sobre o homem, queda provocada na temperatura equivalente ${ }^{14}$, entre outros dados.

\subsection{INCERTEZAS EXPERIMENTAIS}

Vale mencionar alguns fatores relativos aos equipamentos utilizados e às medições efetuadas, que dificultaram ou atrapalharam a realização do monitoramento. Quanto aos HOBOs, sabe-se que a posição ideal para medição de temperatura e umidade é no centro do ambiente, dentro da zona de

\footnotetext{
14 Temperatura de um meio externo isotérmico, hipotético, que dá lugar a um processo de transmissão de calor, na superfície da vedação, igual ao que teria lugar nas condições reais; ou seja, tendo em conta as trocas de calor por convecção com o ar e por radiação com todos os corpos que a rodeiam, incluindo o sol e o céu." (RIVERO, 1988, tradução da autora)
} 
atividade. Porém, não foi possível realizar as medições neste posicionamento, devido ao uso constante dos ambientes analisados, à falta de um local seguro para apoiar os sensores e ao risco de furto (nas edificações de uso público). Por isso, os aparelhos foram sempre dispostos em lugares mais altos, fora do alcance das pessoas, próximos às paredes laterais, o que pode acarretar em alguma influência da radiação emitida pelas vedações sobre os resultados obtidos.

Quanto ao confortímetro, a impossibilidade de realizar medições de velocidade do ar acima de $3 \mathrm{~m} / \mathrm{s}$ foi prejudicial para a pesquisa efetuada em uma das obras analisadas (as Aldeias Infantis SOS), onde o sítio de implantação apresenta ventos locais mais fortes. Quando o vento possui velocidade superior a $3 \mathrm{~m} / \mathrm{s}$, o software do aparelho acusa erro $(9,99 \mathrm{~m} / \mathrm{s})$. Por isso, os dados de velocidade do vento externo não puderam ser propriamente captados nesta obra. Outro fator limitante no uso do confortímetro foi 0 tamanho dos cabos dos anemômetros. Dos quatro sensores extras disponíveis, três apresentam cabo para conexão com a base de $5 \mathrm{~m}$ de comprimento e apenas um possui cabo com 10m de comprimento. Isto impossibilitou a medição de velocidade do ar em todos os pontos desejados dos ambientes analisados, pois o tamanho dos cabos era insuficiente para atingi-los.

É recomendável repetir as medições de velocidade do ar em diferentes períodos do ano, para que os resultados obtidos traduzam o comportamento das edificações em diferentes épocas. Porém, só foi possível realizar o monitoramento uma única vez, devido ao orçamento disponível para esta etapa e à distância da região de estudo. 


\section{AS TRÊS OBRAS SELECIONADAS E OS MÉTODOS DE ANÁLISE}

Quando comenta sobre os edifícios que projetou, Severiano Porto enfatiza os aspectos bioclimáticos presentes, como controle da luminosidade, proteção do sol, ventilação natural, adequação ao clima pela escolha de materiais, desenho de varandas, beirais, brises, elementos vazados, venezianas, preocupação com a preservação da vegetação; o que reforça a importância que o próprio arquiteto dá a este tema (PORTO, 2005; informação verbal). Ele sempre tem estes fatores como preponderantes na atividade projetual, e procura trabalhá-los de acordo com as especificidades de cada projeto: "Independentemente dos materiais, o trópico exige uma arquitetura que respeite a natureza e preste atenção à força do sol, da chuva, dos ventos..." (Severiano Porto in MINGA, 1990) ${ }^{15}$

A arquitetura de Severiano procura atender às especificidades climáticas locais através da utilização de soluções criativas e pertinentes de conforto. $O$ uso de diferentes mecanismos de ventilação natural é solução recorrente em suas obras, dada a importância desta estratégia para o clima de Manaus, como afirma Sabbag (1985): "O cuidado com a ventilação está sempre presente nos projetos de Severiano Porto. Na sua opinião, a casa não deve ser um obstáculo ao vento, que 'deve passar como passa por entre as folhas das árvores'." Uma primeira etapa de análise mais ampla de suas obras, apresentada resumidamente na revisão bibliográfica (item 5.3), foi essencial para um primeiro contato com sua produção arquitetônica e para a escolha de três edifícios para as análises qualitativa e quantitativa.

\subsection{AS OBRAS SELECIONADAS}

Os edifícios escolhidos para o desenvolvimento da pesquisa são: o Campus da Universidade do Amazonas, a Sede da Superintendência da Zona Franca de Manaus e as Aldeias Infantis SOS Brasil. São edifícios que se apresentam atualmente em bom estado de conservação e que são utilizados para o fim a que foram destinados inicialmente. Dois fatores preponderantes que nortearam esta escolha foram, primeiramente, o grande potencial de aproveitamento da ventilação natural nos edifícios, através do uso de diferentes estratégias de ventilação cruzada associada ao efeito chaminé; e também o uso de diferentes soluções visando a obtenção de conforto térmico.

Outro dado relevante para a escolha é o uso de diferentes materiais e sistemas construtivos nas três

15 Entrevista exclusiva cedida por Severiano Porto a MINGA, 1990. Tradução da autora. 
obras. Apesar de Porto ser muito conhecido pelas suas obras em madeira, apresenta obras de diversos materiais e sistemas construtivos. Dentre os edifícios selecionados, o primeiro apresenta sistema construtivo em aço e concreto, o segundo é apenas em concreto e o terceiro é em alvenaria e madeira. Estes fatores são importantes na medida em que, quanto maior a diversidade de estratégias utilizadas e de materiais e sistemas construtivos abordados, mais rica se torna a análise empreendida.

Os capítulos seguintes dividem-se em três, destinados à análise de cada obra em separado. Cada capítulo apresenta, primeiramente, a análise qualitativa e descritiva, onde se encontram todos os dados do projeto e são apresentadas as estratégias de ventilação natural adotadas, com dimensionamento de aberturas e esquemas de fluxo do ar. Em seguida, está a análise quantitativa, onde são apresentados os resultados da pesquisa de campo e a leitura e interpretação dos dados obtidos. Por fim, encontra-se a análise dos resultados, onde a obra é avaliada quanto ao desempenho térmico e às estratégias de ventilação natural encontradas. A seguir, apresenta-se uma descrição detalhada dos métodos escolhidos para a realização das análises.

\subsection{OS MÉTODOS DE ANÁLISE}

Para avaliação do desempenho térmico de uma edificação, são comparadas as condições higrotérmicas do ambiente interno, obtidas através das medições da pesquisa de campo, com valores de referência considerados confortáveis (RORIZ, 1996). Para isso, devem ser estabelecidos parâmetros de análise, de onde se obtêm estes valores de referência. Em vista disso, para análise dos resultados obtidos nas análises qualitativa e quantitativa, foram utilizados dois métodos: as planilhas Mahoney e a ANSI/ASHRAE Standard 55-2004 (AMERICAN SOCIETY OF HEATING, REFRIGERATING AND AIR CONDITIONING ENGINEERS, 2004).

O critério estabelecido pela ASHRAE dá intervalos de temperatura interna considerados confortáveis, de acordo com a temperatura externa encontrada. Já o método de Mahoney determina diretrizes para que haja uma ventilação natural adequada (através de orientações para o desenho de aberturas) e para adoção de sistemas construtivos condizentes ao clima. Os dois métodos se complementam, e fornecem os subsídios necessários para uma análise de desempenho térmico adequada das três obras selecionadas. Para análise de ventilação natural, os valores de referência utilizados foram retirados de literatura especializada e autores consagrados. Mais informações sobre os métodos adotados para análise serão apresentadas a seguir. 


\subsubsection{0 método de Mahoney}

O método de Carl Mahoney (KOENIGSBERGER et al, 1977) foi desenvolvido por solicitação da ONU, na década de 1970, e vem servindo, nas últimas décadas, como um importante instrumento auxiliar no projeto de edificações. Sua maior virtude é dar diretrizes básicas, de uma maneira simplificada, para uma construção adequada em termos de conforto. A zona de conforto é estabelecida para cada clima específico, organizado em grupos. Estes grupos possuem diferentes recomendações, quanto a diversos aspectos de projeto. É um método simples, que fornece diferentes limites de conforto para o dia e para a noite, e chega a quantificar certos elementos construtivos (paredes e cobertura) e a porcentagem de aberturas recomendada.

Para o preenchimento das planilhas, foram utilizadas as Normais Climatológicas publicadas pelo Instituto Nacional de Meteorologia (INMet), referentes ao período de 1961 a 1990, para a cidade de Manaus-AM, apresentados no item 4.1.

Primeira etapa: preenchimento das planilhas

Localidade: Manaus-AM

Latitude: $3,13^{\circ} \mathrm{S}$; Longitude: $60,02^{\circ} \mathrm{O}$; Altitude média: $72 \mathrm{~m}$

Planilha 1 - Normais climatológicas

\begin{tabular}{|l|c|c|c|c|c|c|c|c|c|c|c|c|}
\hline & Jan & Fev & Mar & Abr & Mai & Jun & Jul & Ago & Set & Out & Nov & Dez \\
\hline Média das máximas $\left({ }^{\circ} \mathrm{C}\right)$ & 30,5 & 30,5 & 30,5 & 30,5 & 31 & 31 & 31,5 & 32,5 & 33 & 33 & 32 & 31,5 \\
\hline Média das mínimas $\left({ }^{\circ} \mathrm{C}\right)$ & 23 & 23 & 23 & 23,5 & 23,5 & 23 & 23 & 23 & 23,5 & 24 & 24 & 23,5 \\
\hline Variação das médias & 7,5 & 7,5 & 7,5 & 7 & 8,5 & 8 & 8,5 & 9,5 & 9,5 & 9 & 8 & 8 \\
\hline Umid. relativa média (\%) & 86 & 87 & 88 & 87 & 87 & 83 & 80 & 77 & 77 & 79 & 81 & 85 \\
\hline Pluviosidade (mm) & 260 & 288 & 314 & 300 & 256 & 114 & 88 & 58 & 83 & 126 & 183 & 217 \\
\hline
\end{tabular}

\begin{tabular}{|l|c|c|c|}
\hline Temp. máxima (1) & 31,5 & 27,5 & TMA $=[(1+2) / 2]$ \\
\hline Temp. mínima (2) & 23,5 & 8 & AMA = (1-2) \\
\hline
\end{tabular}


Planilha 2 - Diagnóstico

\begin{tabular}{|c|c|c|c|c|c|c|c|c|c|c|c|c|c|}
\hline & Jan & Fev & Mar & Abr & Mai & Jun & Jul & Ago & Set & Out & Nov & Dez \\
\hline \multicolumn{2}{|c|}{ Grupo de umidade } & 4 & 4 & 4 & 4 & 4 & 4 & 4 & 4 & 4 & 4 & 4 & 4 \\
\hline \multicolumn{2}{|c|}{ Média das máximas } & 30,5 & 30,5 & 30,5 & 30,5 & 31 & 31 & 31,5 & 32,5 & 33 & 33 & 32 & 31,5 \\
\hline \multirow{2}{*}{$\begin{array}{l}\text { Bem estar } \\
\text { diurno }\end{array}$} & Máximo & 27 & 27 & 27 & 27 & 27 & 27 & 27 & 27 & 27 & 27 & 27 & 27 \\
\hline & Mínimo & 22 & 22 & 22 & 22 & 22 & 22 & 22 & 22 & 22 & 22 & 22 & 22 \\
\hline \multicolumn{2}{|c|}{ Média das mínimas } & 23 & 23 & 23 & 23,5 & 23,5 & 23 & 23 & 23 & 23,5 & 24 & 24 & 23,5 \\
\hline \multirow{2}{*}{$\begin{array}{l}\text { Bem estar } \\
\text { noturno }\end{array}$} & Máximo & 21 & 21 & 21 & 21 & 21 & 21 & 21 & 21 & 21 & 21 & 21 & 21 \\
\hline & Mínimo & 17 & 17 & 17 & 17 & 17 & 17 & 17 & 17 & 17 & 17 & 17 & 17 \\
\hline \multirow{2}{*}{$\begin{array}{l}\text { Rigor } \\
\text { térmico }\end{array}$} & Dia & Q & $Q$ & Q & $Q$ & Q & $Q$ & $Q$ & $Q$ & $Q$ & Q & $Q$ & $Q$ \\
\hline & Noite & $Q$ & $Q$ & $Q$ & $Q$ & $Q$ & $Q$ & $Q$ & $Q$ & $Q$ & $Q$ & $Q$ & $Q$ \\
\hline
\end{tabular}

Planilha 3 - Indicadores

\begin{tabular}{|c|c|c|c|c|c|c|c|c|c|c|c|c|c|c|}
\hline & & $\mathrm{J}$ & $\mathbf{F}$ & $M$ & A & $M$ & $\mathrm{~J}$ & $\mathrm{~J}$ & A & $S$ & 0 & $\mathrm{~N}$ & D & Total \\
\hline \multirow{3}{*}{ Umidade } & U1 & $\bar{X}$ & $X$ & $X$ & $X$ & $X$ & 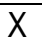 & $X$ & $X$ & $X$ & $X$ & $X$ & $X$ & 12 \\
\hline & $\mathrm{U} 2$ & & & & & & & & & & & & & 0 \\
\hline & U3 & $x$ & $x$ & $X$ & $X$ & $X$ & & & & & & & $X$ & 6 \\
\hline \multirow{3}{*}{ Aridez } & $\mathrm{A} 1$ & & & & & & & & & & & & & 0 \\
\hline & A2 & & & & & & & & & & & & & 0 \\
\hline & A3 & & & & & & & & & & & & & 0 \\
\hline
\end{tabular}

Segunda etapa: recomendações para o projeto arquitetônico (KOENIGSBERGER, 1973; RORIZ, $2001)^{16}$

A- Implantação: edifícios alongados, com fachadas maiores voltadas para Norte e Sul, para reduzir a exposição ao sol. Pode haver um ligeiro desvio nessa orientação para facilitar a captação das brisas dominantes nos meses mais úmidos.

B- Espaçamentos entre as edificações: aumentar distâncias entre edificações para melhor ventilação. De modo geral, para serem realmente eficientes, essas distâncias devem ser, no mínimo, cinco vezes maiores que as alturas dos edifícios. Nesse mesmo sentido, edifícios sobre pilotis podem contribuir.

C- Ventilação: para obter uma ventilação cruzada permanente, as habitações devem ser dispostas em filas simples ao longo do edifício.

D- Tamanho das aberturas: 40 a $80 \%$ das fachadas Norte e Sul, permitindo que o vento atravesse os ambientes ao nível dos corpos das pessoas.

E- Posição das aberturas: Nas fachadas Norte e Sul, permitindo ventilação ao nível dos corpos dos ocupantes. Em dormitórios, onde as pessoas estarão deitadas próximas ao solo, as aberturas devem

${ }^{16}$ Método de Mahoney obtido em Koenigsberger (1973). Detalhamento das recomendações obtido em Roriz (2001), capítulo 11: O método de Mahoney (adaptado) 
chegar praticamente ao piso. Para otimizar a velocidade do ar no interior dos ambientes, as aberturas de saída devem ser ligeiramente maiores e mais altas que as de entrada.

F- Proteção das aberturas: evitar radiação solar direta nos interiores da edificação; proteger cuidadosamente as aberturas contra as chuvas, permitindo ventilação.

G- Paredes e pisos: leves (pouca inércia térmica) e refletores. Superfícies externas das paredes de cores claras para refletirem a radiação solar. Transmitância térmica (U) não superior a $2,8 \mathrm{~W} / \mathrm{m}^{2}{ }^{\circ} \mathrm{C}$, Retardamento máximo de 3 horas e Fator de Calor Solar igual ou inferior a 4\%.

H- Coberturas: leves, termicamente isoladas e que reflitam a radiação do sol. Transmitância térmica não superior a $1,1 \mathrm{~W} / \mathrm{m}^{2}{ }^{\circ} \mathrm{C}$, Retardamento (ou atraso térmico) máximo de 3 horas e Fator de Calor Solar igual ou inferior a $4 \%$.

I- Exterior da edificação: Proteger contra as chuvas. Em climas de forte pluviosidade, a água que escorre das coberturas pode provocar erosão ao redor das edificações bem como comprometer os revestimentos exteriores.

\subsubsection{ASHRAE Standard 55-2004}

O critério 55-2004 da ASHRAE, denominado "Thermal Environmental Conditions for Human Occupancy", foi elaborado para a avaliação térmica de ambientes existentes em edificações. Especifica as condições em que uma fração específica de ocupantes considerará o ambiente termicamente aceitável.

De acordo com a ASHRAE (2004), conforto térmico é definido como a condição mental que expressa satisfação com o ambiente térmico e é analisado por avaliação subjetiva. Devido ao fato de haver grandes variações, tanto psicológicas como fisiológicas, de pessoa para pessoa, é difícil satisfazer a todos dentro de um mesmo espaço, já que as condições ambientais requeridas para obtenção de conforto não são as mesmas para todas as pessoas. Contudo, uma grande quantidade de dados de laboratório e de pesquisas de campo foram coletados, para prover dados estatísticos suficientes para definir condições em que uma certa porcentagem de ocupantes de um ambiente vai considerar termicamente confortáveis. Este modelo determina, portanto, as condições ambientais que são necessárias para que um espaço atinja a aceitação para uma específica porcentagem de ocupantes daquele espaço.

O item 5.3 do método apresenta um gráfico que determina condições térmicas aceitáveis para espaços 
naturalmente condicionados, onde as condições térmicas são reguladas pelos ocupantes através de aberturas. Este gráfico é baseado em um modelo adaptativo de conforto térmico que é derivado de uma base de dados global de 21.000 medições feitas principalmente em edifícios de escritórios. Através dele pode-se determinar intervalos de temperaturas internas aceitáveis, havendo a possibilidade de adoção de dois intervalos de temperatura - um com limite de $80 \%$ de aceitabilidade e outro com limite de $90 \%$ de aceitabilidade. O limite de $80 \%$ é destinado às aplicações típicas; já o limite de $90 \%$ deve ser usado quando se deseja um padrão mais elevado de conforto térmico. Para utilizá-lo, são necessários dados mensais de temperatura externa do local, não sendo requeridos dados de umidade ou velocidade do ar. 0 gráfico é o que se apresenta a seguir:

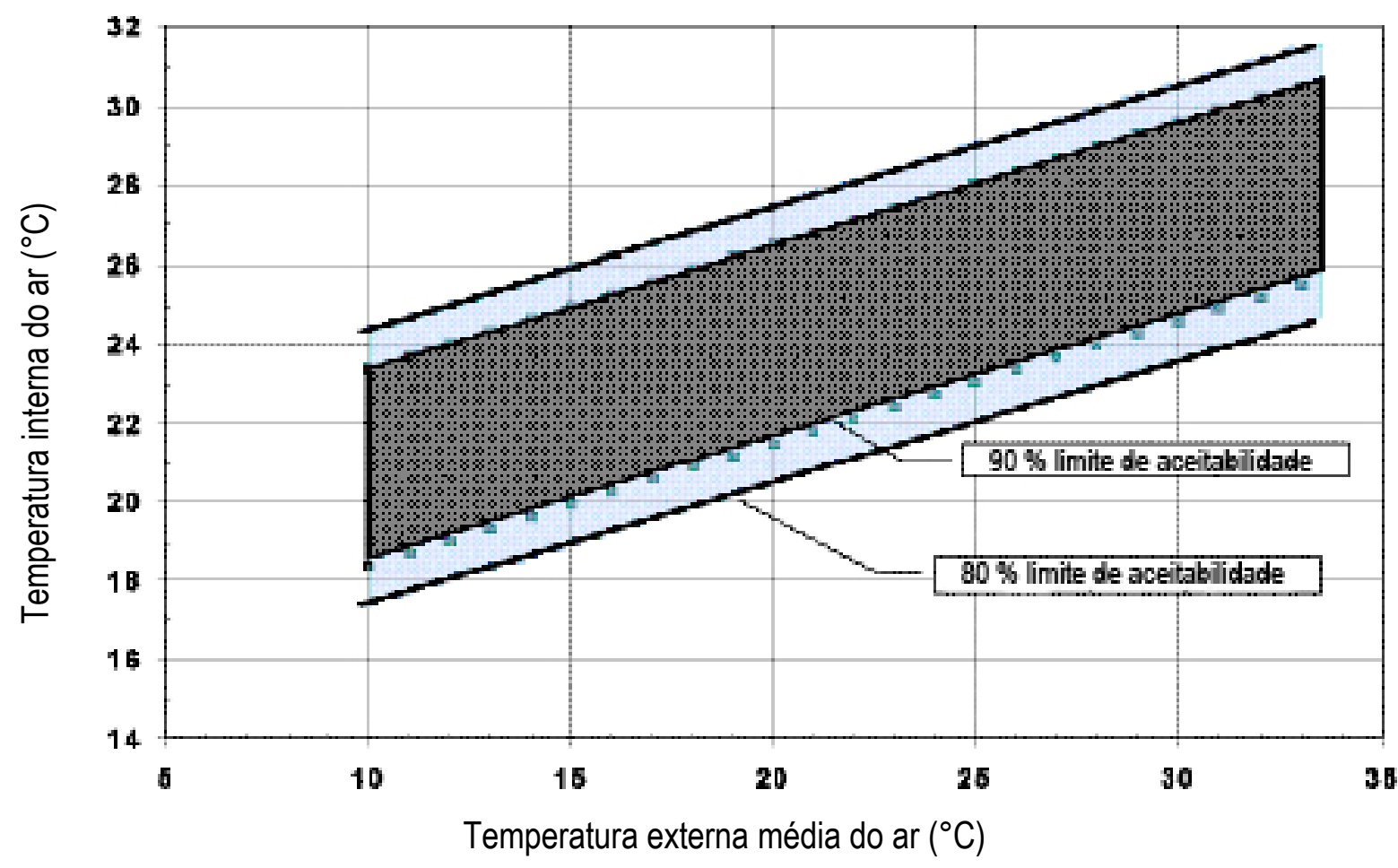

Gráfico 7.1: Intervalos de temperatura interna aceitáveis para espaços naturalmente condicionados ${ }^{17}$ (Modificado de: ASHRAE Standard, 2004)

As médias mensais de temperatura externa utilizadas foram as Normais Climatológicas da cidade de Manaus dos anos 1961 a 1990. O limite recomendado adotado foi de $80 \%$ de aceitabilidade dos usuários de um espaço. Ao determinar as equações das retas do gráfico, podem-se calcular os valores da temperatura interna recomendada. Para o limite inferior de temperatura interna, a equação é:

$$
\text { Temp. int }=[3(\text { Temp. ext })+145] / 10
$$

\footnotetext{
17 Para este método não são necessários dados sobre umidade relativa e velocidade do ar (ASHRAE Standard, 2004).
} 
Para o limite superior:

$$
\text { Temp. int }=[3(\text { Temp. ext })+215] / 10
$$

Os resultados são os que se apresentam na tabela seguinte:

Tabela 7.1 - Intervalos de temperatura interna recomendados pela ASHRAE, em relação à temperatura média externa ${ }^{18}$

\begin{tabular}{|c|c|c|c|c|c|c|c|c|c|c|c|c|}
\hline & Jan & Fev & Mar & Abr & Mai & Jun & Jul & Ago & Set & Out & Nov & $\overline{\text { Dez }}$ \\
\hline Temp. externa média $\left({ }^{\circ} \mathrm{C}\right)$ & 26,1 & 26 & 26,1 & 26,3 & 26,3 & 26,4 & 31,3 & 32,6 & 32,9 & 32,8 & 32,1 & 31,3 \\
\hline \multicolumn{13}{|l|}{ Temp. interna recomendada } \\
\hline Máxima $\left({ }^{\circ} \mathrm{C}\right)$ & 29,3 & 29,3 & 29,3 & 29,4 & 29,4 & 29,4 & 30,9 & 31,3 & 31,4 & 31,3 & 31,1 & 30,9 \\
\hline Mínima $\left({ }^{\circ} \mathrm{C}\right)$ & 22,3 & 22,3 & 22,3 & 22,4 & 22,4 & 22,4 & 23,9 & 24,3 & 24,4 & 24,3 & 24,1 & 23,9 \\
\hline
\end{tabular}

\subsubsection{Os parâmetros para análise de ventilação natural}

As metodologias existentes para análise de ventilação natural não abordam de forma aprofundada todos os aspectos envolvidos no fenômeno. Algumas analisam apenas a ventilação cruzada ou apenas o efeito chaminé, algumas são destinadas a tipologias específicas de edifício, algumas fornecem apenas dados gerais de taxa de ventilação (TOLEDO, 2001). O método de Mahoney, aqui utilizado, apresenta apenas dados genéricos de ventilação natural. $O$ dimensionamento das aberturas é estabelecido em função da área da parede, não havendo diferenciação entre o tamanho das aberturas de entrada e de saída do ar. Indica posicionamento, localização e proteção adequados às aberturas, mas apenas de forma generalizada, não apresentando qualquer dado sobre velocidade do ar e seu efeito sobre os usuários.

Por isso, considera-se de grande importância o uso de dados obtidos na literatura especializada corrente, como forma de complementação à análise de ventilação natural. Estes dados, juntamente com as recomendações dadas por Mahoney, serão utilizados como parâmetros para análise das obras selecionadas.

Mahoney determina o tamanho das aberturas, em relação à área das paredes, para que haja uma ventilação cruzada adequada (entre 40 e 80\%). Contudo, faz-se necessária uma análise mais profunda do efeito causado pelo tamanho das aberturas de entrada e saída do ar sobre a ventilação cruzada. Givoni (1976) encontrou uma relação entre a velocidade interna, o tamanho das aberturas e a direção

18 Os dados dos meses de janeiro e fevereiro (em destaque) serão utilizados na análise de resultados das obras, já que nestes meses foi realizada a pesquisa de campo. 
do vento através de estudos experimentais realizados por meio de ensaios em túnel de vento em um modelo de ambiente quadrado, com aberturas simples (tabela 7.2). Ele determina uma relação entre a largura das aberturas e o aproveitamento do vento externo disponível, para ambientes com janelas em paredes opostas ou adjacentes, considerando duas direções de vento - perpendicular e oblíqua às aberturas de entrada do ar. A altura permanece constante: é sempre considerada como sendo 1/3 da altura total da parede. A velocidade do ar interior é expressa em porcentagem da velocidade do vento livre no exterior do edifício, e representa um valor médio. Estes dados são úteis para comparar o fluxo de ar esperado e o obtido pelas medições realizadas na pesquisa de campo.

Tabela 7.2 - Efeito do tamanho das aberturas na velocidade interna média de um ambiente (\% da velocidade externa) - (GIVONI, 1976)

\begin{tabular}{|c|c|c|c|c|c|}
\hline \multirow{2}{*}{$\begin{array}{c}\text { Entrada ventilação } \\
\text { (\% do vão) }\end{array}$} & \multirow{2}{*}{$\begin{array}{c}\text { Saída ventilação } \\
\text { (\% do vão) }\end{array}$} & \multicolumn{2}{|c|}{ Janelas em paredes opostas } & \multicolumn{2}{c|}{$\begin{array}{c}\text { Janelas em paredes } \\
\text { adjacentes }\end{array}$} \\
\cline { 3 - 6 } & & $\begin{array}{c}\text { Vento } \\
\text { perpendicular }\end{array}$ & Vento oblíquo & $\begin{array}{c}\text { Vento } \\
\text { perpendicular }\end{array}$ & Vento oblíquo \\
\hline $1 / 3$ & $1 / 3$ & 35 & 42 & 45 & 37 \\
\hline $1 / 3$ & $2 / 3$ & 39 & 40 & 39 & 40 \\
\hline $2 / 3$ & $1 / 3$ & 34 & 43 & 51 & 36 \\
\hline $2 / 3$ & $2 / 3$ & 37 & 51 & - & - \\
\hline $1 / 3$ & $3 / 3$ & 44 & 44 & 51 & 45 \\
\hline $3 / 3$ & $1 / 3$ & 32 & 41 & 50 & 37 \\
\hline $2 / 3$ & $3 / 3$ & 35 & 59 & - & - \\
\hline $3 / 3$ & $2 / 3$ & 36 & 62 & - & - \\
\hline $3 / 3$ & $3 / 3$ & 47 & 65 & - & - \\
\hline
\end{tabular}

Neste mesmo estudo, Givoni (1976) também indica a velocidade interna máxima que pode ser obtida (além dos valores médios, apresentados na tabela 7.2), para diferentes proporções de aberturas de entrada e saída do ar, em ambientes com aberturas localizadas em paredes opostas. Estes valores também são expressos em porcentagem da velocidade externa, e são apresentados na tabela 7.3.

Tabela 7.3 - Efeito do tamanho das aberturas de ventilação nas velocidades média e máxima internas (\% da velocidade externa) - (GIVONI, 1976)

\begin{tabular}{|c|c|c|c|c|c|c|c|}
\hline \multirow{2}{*}{$\begin{array}{c}\text { Direção } \\
\text { vento }\end{array}$} & \multirow{2}{*}{$\begin{array}{c}\text { Saída ventilação } \\
\text { (\% do vão) }\end{array}$} & \multicolumn{6}{|c|}{ Entrada ventilação (\% do vão) } \\
\cline { 3 - 8 } & & \multicolumn{2}{|c|}{$\mathbf{1 / 3}$} & \multicolumn{2}{|c|}{$\mathbf{2 / 3}$} & \multicolumn{2}{c|}{$\mathbf{3 / 3}$} \\
\cline { 3 - 8 } & $1 / 3$ & 36 & 65 & 34 & 74 & 32 & 49 \\
\hline \multirow{3}{*}{ Perpendicular } & $2 / 3$ & 39 & 131 & 37 & 79 & 36 & 72 \\
\cline { 2 - 8 } & $3 / 3$ & 44 & 137 & 35 & 72 & 47 & 86 \\
\hline \multirow{3}{*}{ Oblíquo } & $1 / 3$ & 42 & 83 & 43 & 96 & 42 & 62 \\
\cline { 2 - 8 } & $2 / 3$ & 40 & 92 & 57 & 133 & 62 & 131 \\
\cline { 2 - 8 } & $3 / 3$ & 44 & 152 & 59 & 137 & 65 & 115 \\
\hline
\end{tabular}


Estes dados permitem analisar a efetividade da ventilação natural de acordo com as características básicas das aberturas e do vento externo. Para análise do efeito causado pela velocidade do ar sobre os usuários de um recinto, faz-se necessário o estabelecimento de parâmetros de percepção do vento em função de seus efeitos sobre o homem. Uma escala muito conhecida é a escala de Beaufort, idealizada em 1805 para qualificar ventos no mar pelos seus efeitos sobre os navios à vela e o aspecto das ondas. Posteriormente, a escala foi adaptada também para uso em terra, estabelecendo relação com os efeitos do vento sobre o homem, as árvores e os edifícios.

Tabela 7.4 - Escala de força do vento de Beaufort ${ }^{19}$ (FREIXANET; VIQUEIRA, 2004)

\begin{tabular}{|c|l|c|l|l|}
\hline $\begin{array}{c}\text { Graus } \\
\text { Beaufort }\end{array}$ & Descrição & $\begin{array}{c}\text { Velocidades } \\
(\mathrm{m} / \mathbf{s})\end{array}$ & \multicolumn{1}{|c|}{ Efeito no homem } & \multicolumn{1}{c|}{$\begin{array}{c}\text { Efeito em edifícios e } \\
\text { vegetação }\end{array}$} \\
\hline 0 & Calma & $0,0-0,5$ & Nenhum. & $\begin{array}{l}\text { A fumaça sobe verticalmente e a } \\
\text { superfície da água está tranqüila. }\end{array}$ \\
\hline 1 & Ar ligeiro & $0,6-1,5$ & $\begin{array}{l}\text { Movimento apenas percebido } \\
\text { devido ao efeito de esfriamento. }\end{array}$ & $\begin{array}{l}\text { A direção do vento já é apontada } \\
\text { pela fumaça. }\end{array}$ \\
\hline 2 & Brisa ligeira & $1,6-3,3$ & O ar fresco se sente sobre o rosto. & Balançam as folhas das árvores. \\
\hline 3 & Brisa suave & $3,4-5,4$ & $\begin{array}{l}\text { O cabelo se move, ligeiro } \\
\text { movimento da roupa, começa a } \\
\text { incomodar. }\end{array}$ & $\begin{array}{l}\text { As folhas e os ramos das árvores se } \\
\text { movem. }\end{array}$ \\
\hline
\end{tabular}

Esta escala foi um dos primeiros estudos dos efeitos do vento sobre o homem, porém não é adequada para análise de ambientes internos, onde as velocidades do ar são consideravelmente menores do que em áreas abertas. Por isso, será utilizada como parâmetro de análise a escala de Olgyay (1998), que apresenta dados que estimam os efeitos causados pela velocidade do ar em usuários de um ambiente com ventilação natural. Segundo Olgyay, os efeitos da velocidade do vento sobre os seres humanos são os seguintes:

Tabela 7.5 - Efeitos da ventilação natural sobre o homem ${ }^{20}$ (OLGYAY, 1998)

\begin{tabular}{|c|c|}
\hline \multicolumn{2}{|c|}{ Ventilação e seus efeitos } \\
\hline Velocidade $(\mathbf{m} / \mathbf{s})$ & Efeito \\
\hline Até 0,25 & Imperceptível \\
\hline $0,25-0,5$ & Agradável \\
\hline $0,5-1,0$ & $\begin{array}{c}\text { Geralmente é agradável, mas percebe-se constantemente a } \\
\text { sua presença. }\end{array}$ \\
\hline $1,0-1,5$ & De pouco a muito incômodo. \\
\hline Mais de 1,5 & $\begin{array}{c}\text { Requer medidas corretivas se é desejável manter um alto } \\
\text { nivel de saúde e eficiência. }\end{array}$ \\
\hline
\end{tabular}

\footnotetext{
${ }^{19}$ A escala só foi reproduzida até a velocidade do ar que interessa ao meio urbano, a tabela original vai até 12 graus Beaufort. Tradução da autora.

20 Tradução da autora.
} 
Evans (1957 apud FREIXANET; VIQUEIRA, 2004)21, além de avaliar os efeitos causados pelo vento sobre os usuários de um determinado espaço, também indica a sensação de resfriamento provocada por diferentes velocidades de vento. Sabe-se que o movimento do ar pode ser utilizado para reduzir a temperatura equivalente, pelo efeito de resfriamento fisiológico resultante da evaporação do suor da pele. Por isso, é importante estimar a velocidade de vento necessária para que se possa atingir a temperatura da zona de conforto nos períodos mais quentes, ou ao menos se aproximar dela.

Tabela 7.6 - Velocidades do vento em espaços interiores e seu efeito sobre os usuários ${ }^{22}$ (EVANS,

1957 apud FREIXANET; VIQUEIRA, 2004)

\begin{tabular}{|c|l|l|c|}
\hline $\begin{array}{c}\text { Velocidade } \\
(\mathbf{m} / \mathbf{s})\end{array}$ & \multicolumn{1}{|c|}{ Efeito mecânico } & \multicolumn{1}{|c|}{ Efeito sobre o usuário } & $\begin{array}{c}\text { Efeito de } \\
\text { esfriamento }\left({ }^{\circ} \mathbf{C}\right)\end{array}$ \\
\hline 0,1 & $\begin{array}{l}\text { Mínimo em ambiente } \\
\text { doméstico. }\end{array}$ & Pode-se sentir sufocação. & 0,0 \\
\hline 0,25 & $\begin{array}{l}\text { A fumaça do cigarro } \\
\text { indica o movimento. }\end{array}$ & $\begin{array}{l}\text { Há movimento imperceptível exceto a baixas } \\
\text { temperaturas de ar. }\end{array}$ & 0,7 \\
\hline 0,5 & $\begin{array}{l}\text { Movimento da chama } \\
\text { de uma vela. }\end{array}$ & $\begin{array}{l}\text { Sensação de frescor a temperaturas confortáveis, } \\
\text { porém incomoda a baixas temperaturas. }\end{array}$ & 1,2 \\
\hline 1,0 & $\begin{array}{l}\text { Os papéis soltos podem } \\
\text { se mover, o que } \\
\text { equivale à velocidade } \\
\text { no caminhar. }\end{array}$ & $\begin{array}{l}\text { Agradável geralmente quando o clima é confortável ou } \\
\text { quente, porém causa sensação de movimento } \\
\text { constante. É o nível máximo aceitável de conforto } \\
\text { noturno. }\end{array}$ & 2,2 \\
\hline 1,5 & $\begin{array}{l}\text { Muito rápido para } \\
\text { trabalho de escritório, } \\
\text { os papéis voam. }\end{array}$ & $\begin{array}{l}\text { Incômodo a temperaturas confortáveis. Limite máximo } \\
\text { de conforto para atividades internas. }\end{array}$ & 3,3 \\
\hline 2,0 & $\begin{array}{l}\text { Equivale à velocidade } \\
\text { no caminhar rápido. }\end{array}$ & $\begin{array}{l}\text { Aceitável só em condições muito quente e úmidas, } \\
\text { quando nenhum outro alivio ambiental está disponivel. }\end{array}$ & 4,2 \\
\hline
\end{tabular}

Borel (1967), em um estudo mais recente, também apresenta valores de queda na temperatura equivalente, em conseqüência da ventilação natural, que provoca sensação de esfriamento no ocupante de um ambiente. Os valores são calculados em conseqüência tanto da velocidade como da temperatura do ar. Os dados resultantes estão no gráfico seguinte:

${ }^{21}$ EVANS, B. H. Research Report 59, Texas, Texas Engineering Station, College Station, 1957. Tradução da autora.

${ }^{22}$ Só foram reproduzidos os dados para pele úmida, a $30^{\circ} \mathrm{C}$. Tradução da autora. 


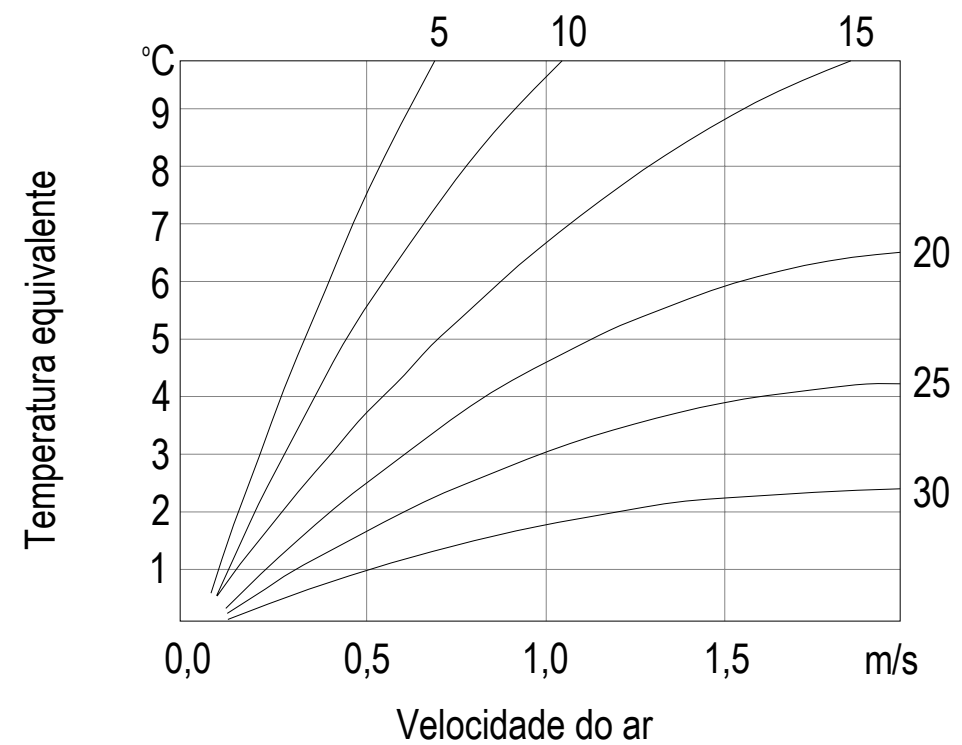

Gráfico 7.2: Queda na temperatura equivalente, percebida pelos usuários de um espaço, em função da velocidade do ar, para diferentes temperaturas (BOREL, 1967)

Através dos dados obtidos na análise qualitativa - de dimensões do ambiente, tamanho das aberturas em relação à parede, relação entre as aberturas de entrada e saída do ar - e das medições de velocidade do vento obtidas na análise quantitativa, pode-se utilizar os parâmetros aqui apresentados para empreender uma análise da contribuição da ventilação natural sobre o desempenho térmico dos edifícios analisados. 


\section{CAMPUS DA UNIVERSIDADE DO AMAZONAS, 1973-80}

Quando questionado sobre quais de suas obras apresentam questões de ventilação natural melhor trabalhadas, Severiano Porto (2005) imediatamente cita o projeto para a Universidade do Amazonas, atual Universidade Federal do Amazonas (UFAM), um dos projetos mais marcantes e conhecidos de sua carreira. Neste projeto, Porto procura proporcionar melhores condições de conforto aos usuários através da utilização de diferentes estratégias de ventilação natural, frequentemente apresentando soluções de ventilação cruzada aliada ao efeito chaminé, em um trabalho cuidadoso com a disposição de aberturas. Devido a estes fatores, é uma obra que merece ser analisada.

\subsection{ANÁLISE QUALITATIVA E DESCRITIVA}

A procura por uma inserção arquitetônica em conformidade com o meio ambiente direcionou Porto na definição do projeto para o campus universitário da Universidade do Amazonas, em Manaus: "A preocupação do enquadramento às características locais, econômicas, climáticas e topográficas em todos os momentos constituiu uma dominante." (ZEIN, 1986). A área de 600 hectares destinada ao campus era cercada de nascentes e envolvida pela vegetação tropical nativa, o que pedia um projeto de baixo impacto ambiental, com o mínimo de interferência possível na paisagem original. Isto levou 0 arquiteto a trabalhar, desde o início, um pensamento ecológico em sua arquitetura, e a elaborar um de seus projetos onde os aspectos bioclimáticos mais se destacam.

Assim, o arquiteto procurou manter o máximo possível a vegetação original do terreno, através de uma busca constante de integração entre construção e natureza. Esta atitude, além de auxiliar na preservação das áreas verdes, resultou em um projeto adequado ao clima tropical e que procura resolver os problemas de conforto da região: "La solución arquitectónica ha procurado integrarse a este escenario sin agredirlo e intentando crear condiciones naturales de confort, prescindiendo del uso del aire acondicionado en la mayoría de los locales." (SUMMA, 1985)

Além do baixo impacto ambiental e interferência mínima na paisagem original, outras premissas projetuais importantes foram a adequação às características climáticas e topográficas locais, o baixo custo de manutenção da obra e a flexibilidade para futuras adaptações e ampliações. 


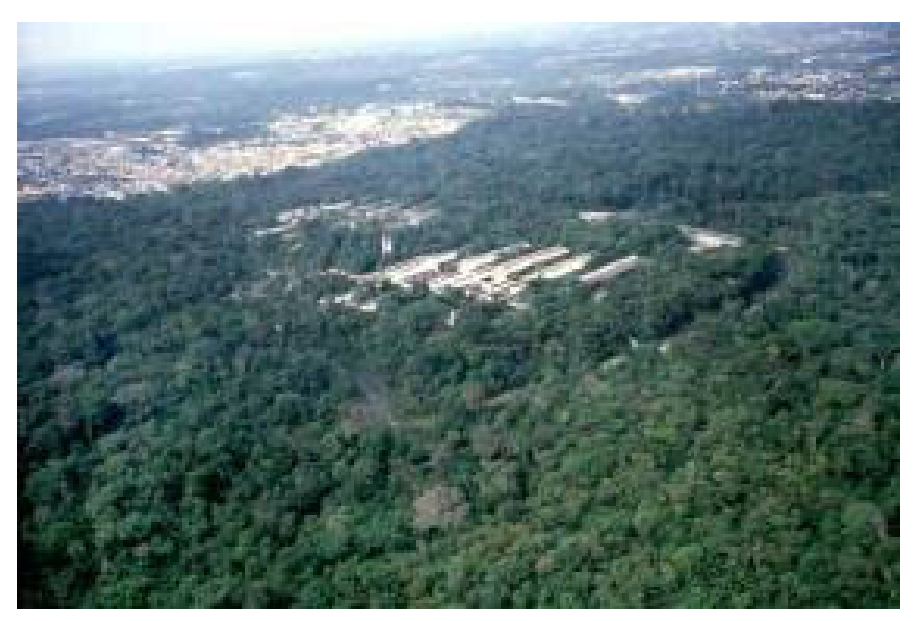

Figura 8.1: Vista aérea do campus (SABBAG, 2003)

\subsection{1 Área de inserção e implantação}

Quando os estudos preliminares para elaboração do projeto foram iniciados, no começo da década de 70, Porto procurou conhecer a fundo a região de intervenção, sua vegetação e topografia, a fim de definir uma área adequada para implantação. A área destinada ao campus possuía uma topografia relativamente acidentada se comparada com o restante da cidade, com desníveis de 30 a 40 metros, e dois platôs em cotas mais elevadas, um que já era ocupado pelas instalações provisórias do minicampus - obra do arquiteto Mário Toledo - e o outro que foi escolhido para o projeto, definido pela cota 94 e que se situa no centro geográfico do terreno. A escolha baseou-se na busca por um mínimo de agressão ao ambiente natural.

O arruamento é periférico e procura adaptar-se à topografia do terreno, que nessa área é mais acidentada, acomodando-se às curvas de nível nas cotas mais altas e não prejudicando as nascentes. Os carros são distribuídos em zonas de estacionamento e os acessos aos edifícios se dão por uma rede de circulação de pedestres, que integra os diversos blocos e dá suporte estrutural ao conjunto. 


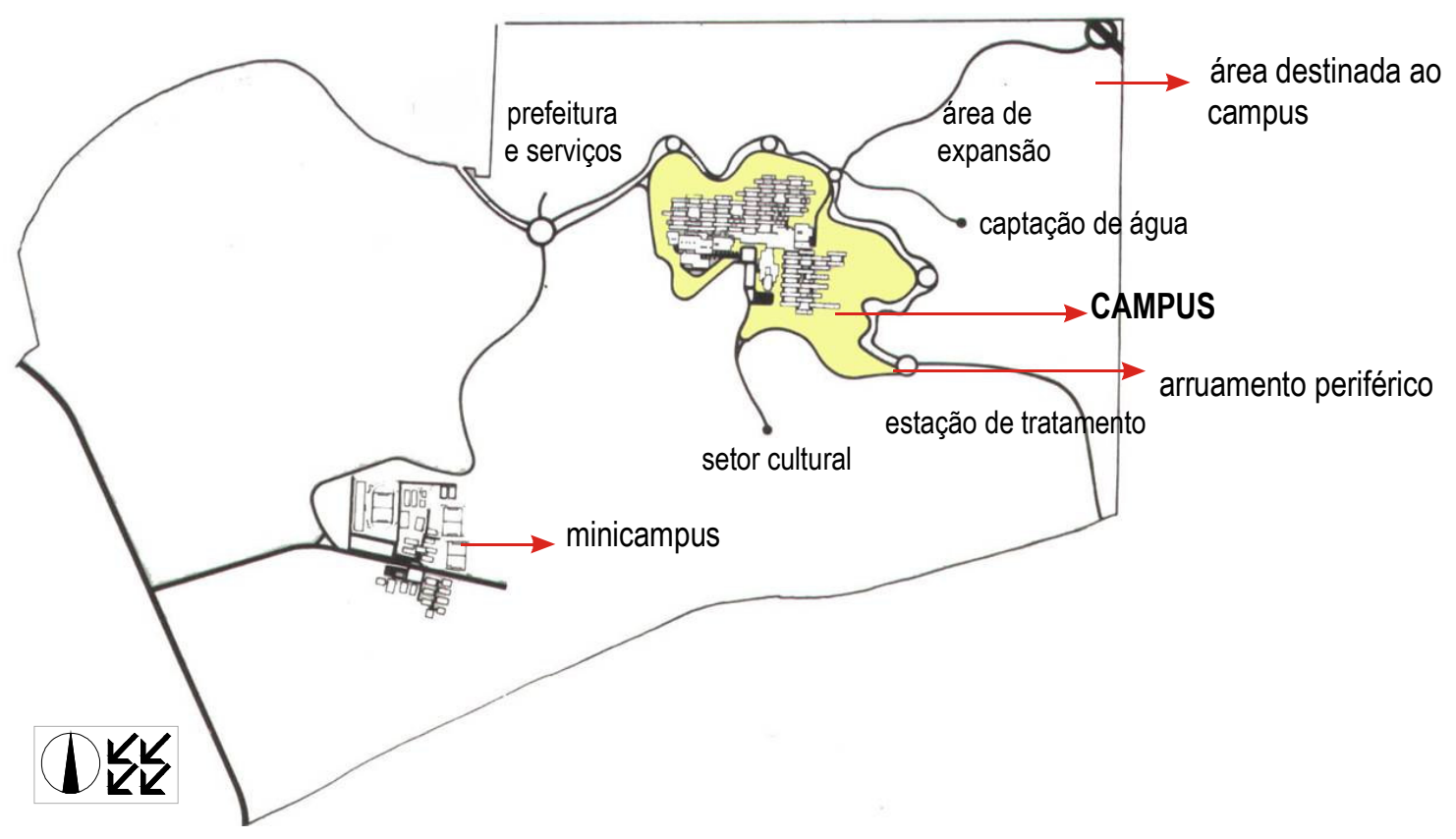

Figura 8.2: Planta geral do campus e rede viária (PENTEADO et al, 1986)

\subsubsection{Os edifícios}

Para garantir uma unidade ao projeto e proporcionar uma certa flexibilidade para futuras reformas, adaptações e ampliações, o partido proposto consistiu em um sistema de malha modular para a implantação das edificações, onde os pavilhões se unem por circulações cobertas, envolvidas por jardins e áreas verdes. 0 projeto, que cobre uma área de 100 mil metros quadrados, é composto por coberturas-tipo, que dão liberdade para os mais diversos tipos de arranjo e se adequam a qualquer uso. A concentração de equipamentos buscou minimizar os investimentos e facilitar circulações e convívio. As passarelas proporcionam acessos fáceis e são trabalhadas de forma a comporem hora simples passagens, em locais que exigem maior silêncio, hora espaços mais amplos e equipados, que configuram áreas de estar (figuras 8.4 a 8.7).

Os prédios foram implantados com as maiores fachadas na direção Norte-Sul, de acordo com os ventos dominantes da região, que são Nordeste, e se adequam às curvas de nível do terreno, evitando grandes movimentos de terra e desmatamentos. 
O programa abordado inclui as seguintes edificações:

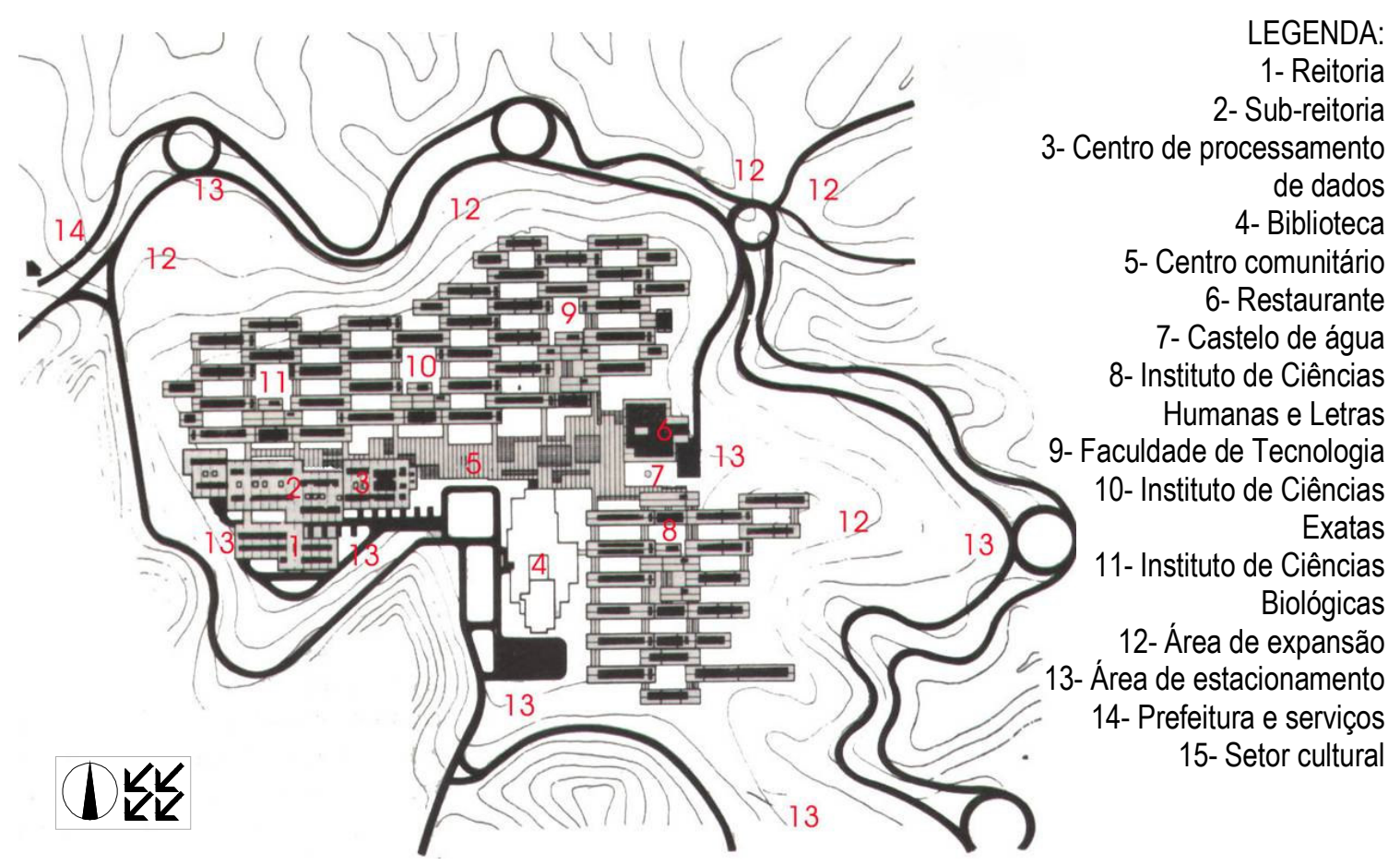

Figura 8.3: Planta geral do campus (PENTEADO et al, 1986)

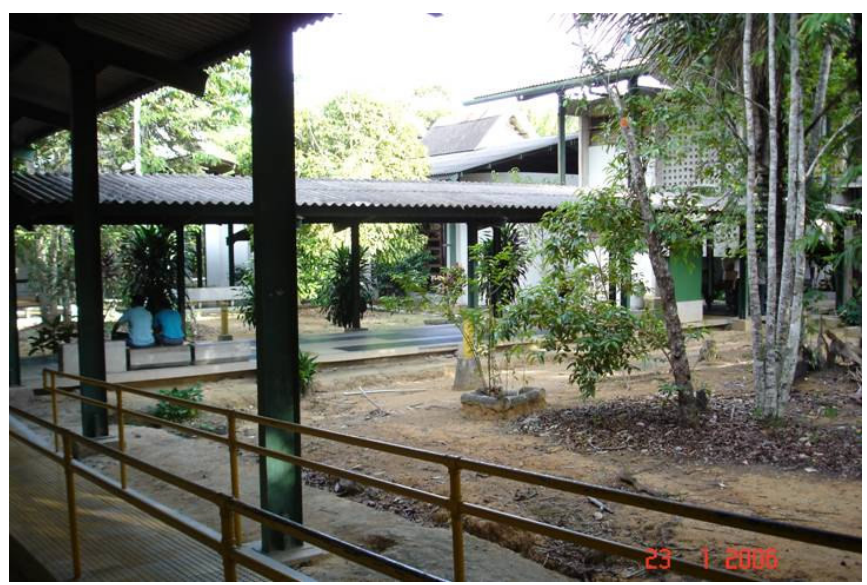

Figura 8.4: Circulações cobertas, rodeadas por jardim

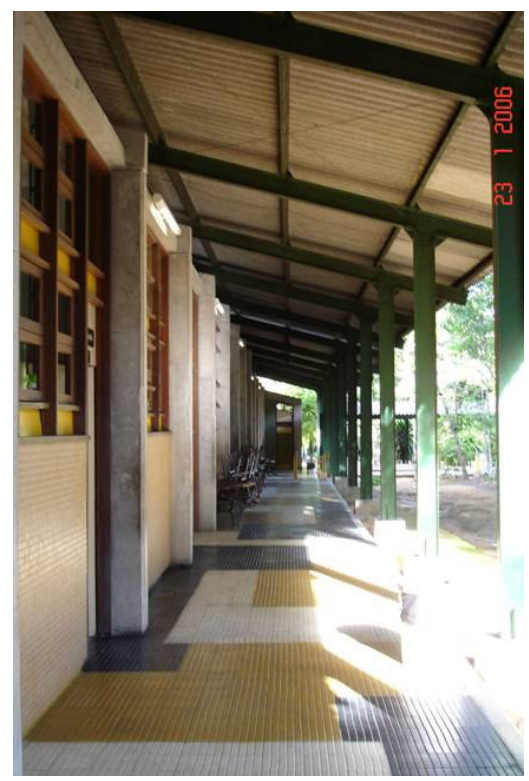

Figura 8.5: Circulação coberta 


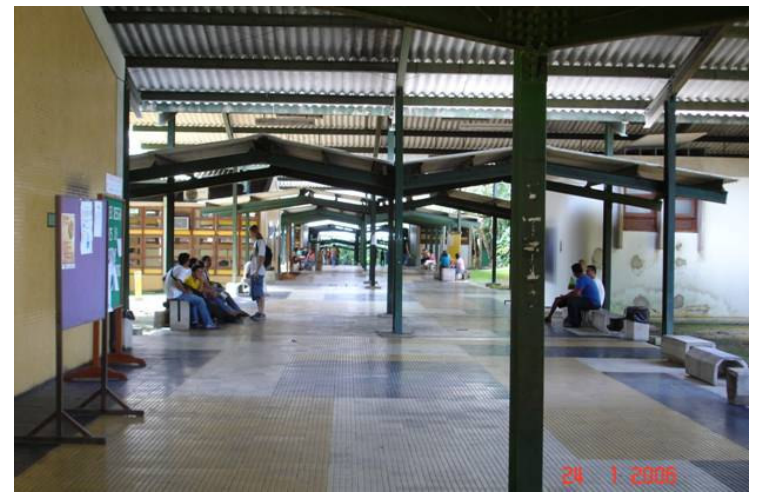

Figura 8.6: Área de estar coberta

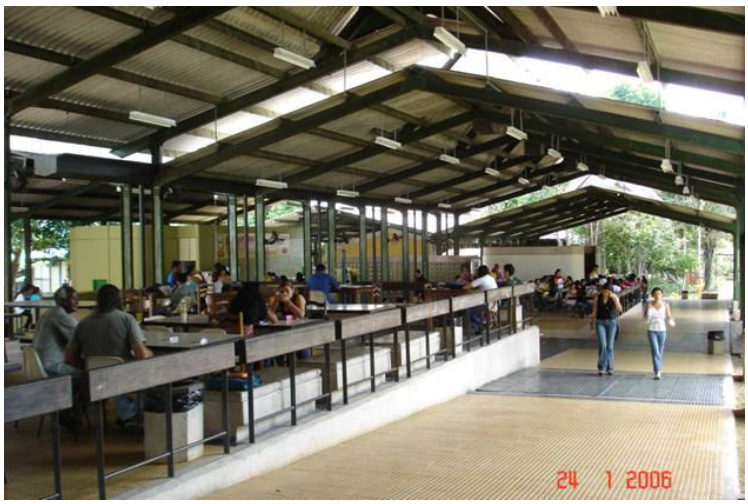

Figura 8.7: Área de alimentação coberta

\subsubsection{Sistema construtivo e materiais}

As coberturas-tipo foram projetadas em estrutura metálica em sistema modular, o que facilitava tanto a etapa de construção e montagem - que deveria ser realizada no curto período da seca - quanto futuras ampliações e manutenções; já que se trata de uma obra estatal. Dentro das diretrizes de modificar o mínimo possível a topografia original, as estruturas metálicas foram a solução para fácil montagem entre as irregularidades do terreno. A padronização permite a fácil aquisição e formação de estoque, além da rápida execução, impedindo a interrupção do trabalho pelas constantes chuvas da região.

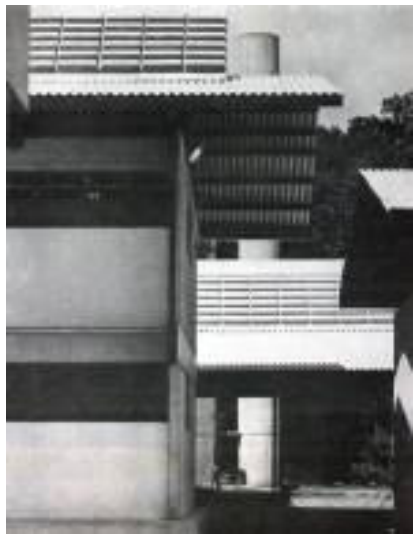

Figura 8.8: Coberturas-tipo em estrutura metálica (PENTEADO el al, 1986)

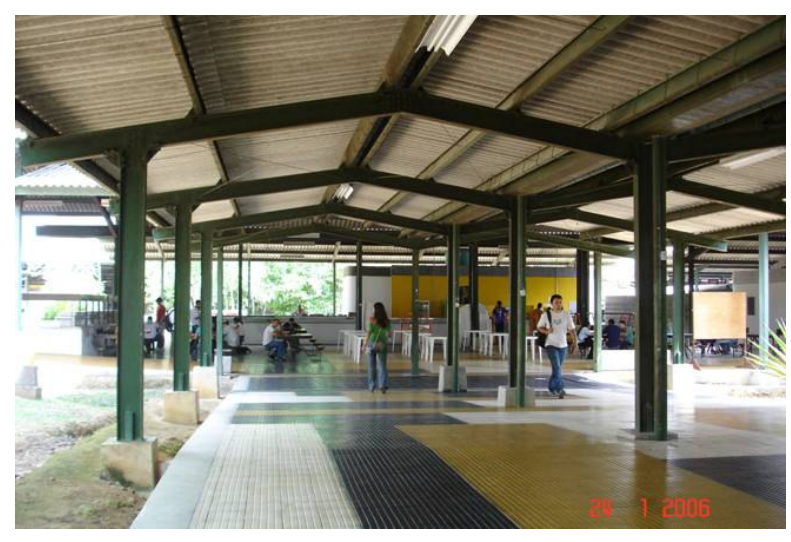

Figura 8.9: Vista interna da estrutura metálica 
Os materiais predominantes no projeto do campus são estrutura metálica, concreto e alvenaria. Internamente à cobertura, os ambientes são construídos independentemente, o que proporciona grande flexibilidade de arranjo de acordo com o programa de cada bloco. São utilizados concreto nas lajes de forro e alvenaria ou placas divisórias nas vedações. Interiormente os ambientes são revestidos de fórmica bege até a altura de 1,80m, e externamente são revestidos de mosaico cerâmico. As telhas são de fibrocimento ondulado, pintadas de branco.

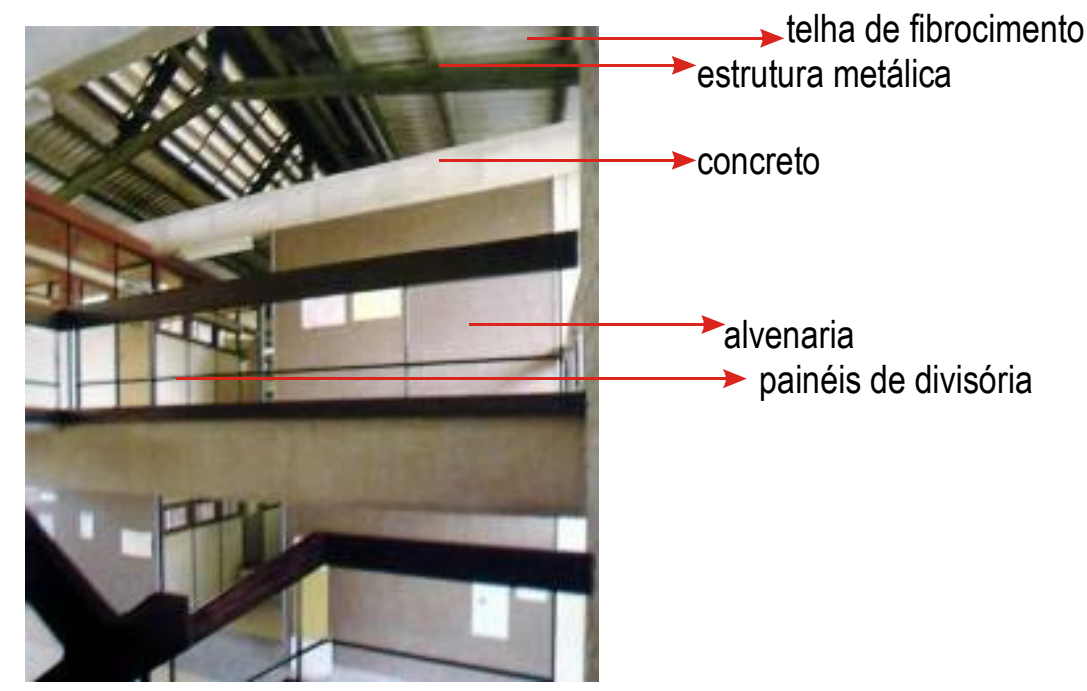

Figura 8.10: Vista interna - circulação (PROJETO, 1988)

\subsubsection{Estratégias bioclimáticas e conforto ambiental}

A densidade das edificações na universidade é adequada às características climáticas da região, que apresenta altas taxas de precipitação e constante insolação, pedindo, portanto, grandes coberturas e circulações cobertas. As circulações de pedestres, cujos eixos maiores estão orientados na direção Norte-Sul, oferecem proteção do sol e das chuvas e proporcionam a ligação entre os diversos equipamentos. Jardins são dispostos regularmente entre os edifícios, oferecendo grandes áreas sombreadas.

As menores fachadas estão voltadas para a direção Leste-Oeste (figura 8.11), o que reduz significativamente a exposição à radiação solar e expõe as fachadas maiores aos ventos dominantes da região, que são predominantemente Nordeste. Além da orientação favorável, a forma alongada das edificações, em sua maioria $60 \times 12,5 \mathrm{~m}$, também contribui neste aspecto. 

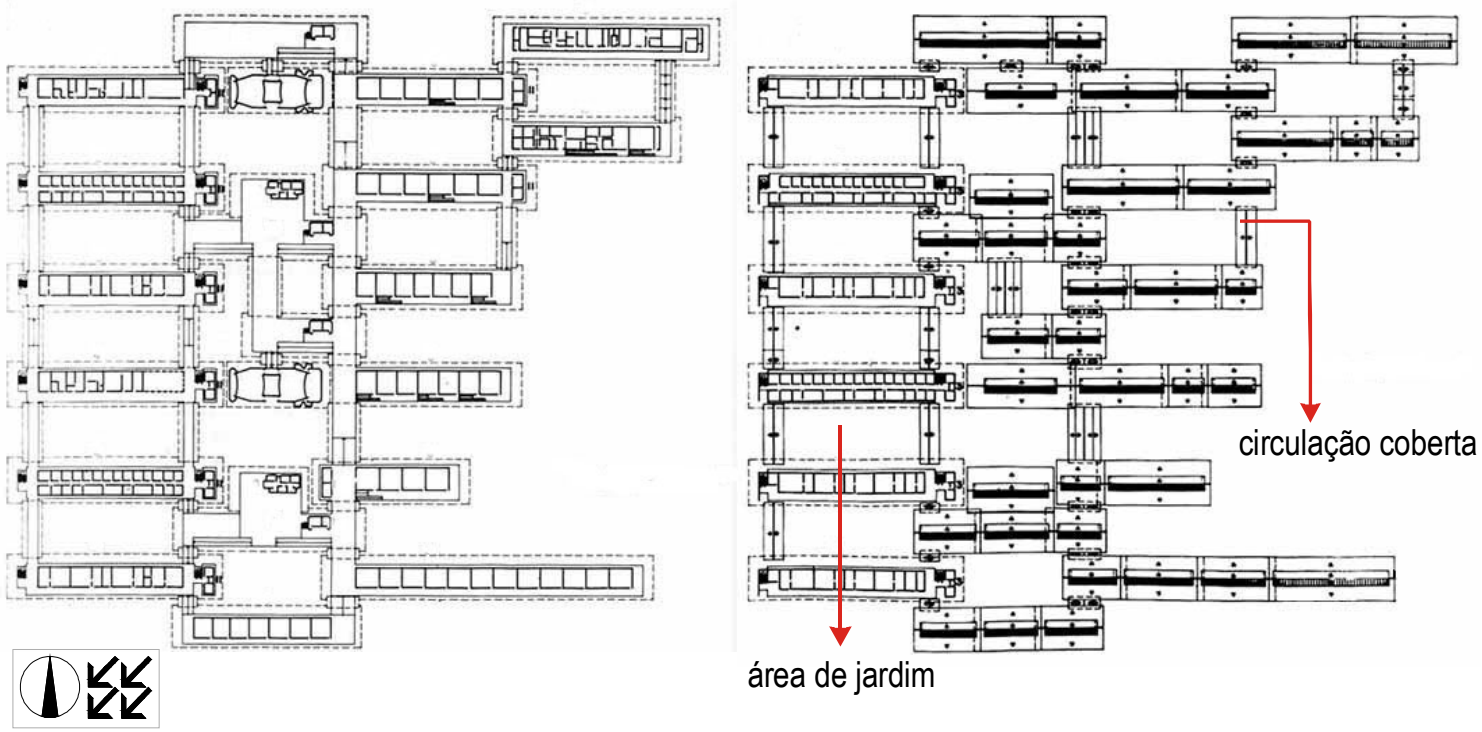

Figuras 8.11 e 8.12: Planta geral da faculdade - pavimentos térreo e superior (SABBAG, 2003)

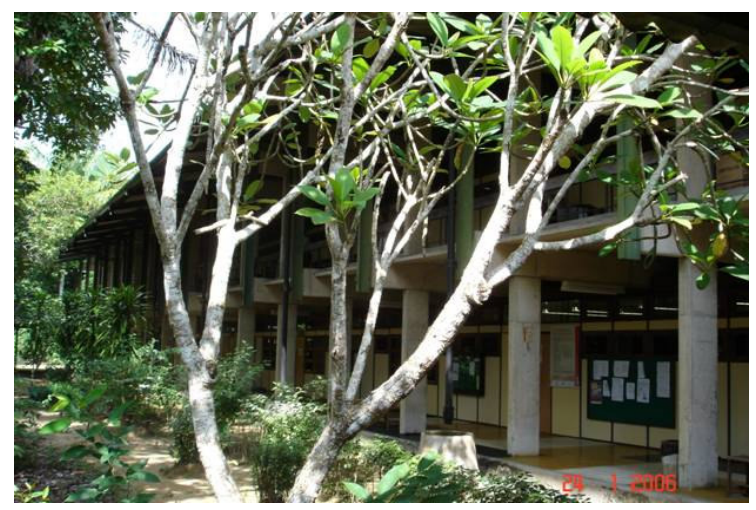

Figura 8.13: Vista do jardim entre as edificações

Como Manaus situa-se próxima à linha do Equador (latitude de $3,13^{\circ} \mathrm{Sul}$ ), o plano formado pela trajetória aparente do sol apresenta ângulo de inclinação próximo a $90^{\circ}$ durante 0 ano todo, em relação ao plano do solo (figura 8.14). Assim, a cobertura é a face do edifício mais atingida pela radiação solar, o que a torna o elemento mais importante da construção na proteção à radiação. Dessa forma, a estrutura metálica independente da cobertura funciona como uma ampla proteção para o edifício e as circulações do entorno, através de grandes beirais. As circulações externas, ao longo dos edifícios, são dispostas do lado oposto aos ventos dominantes, para proteção da chuva. 


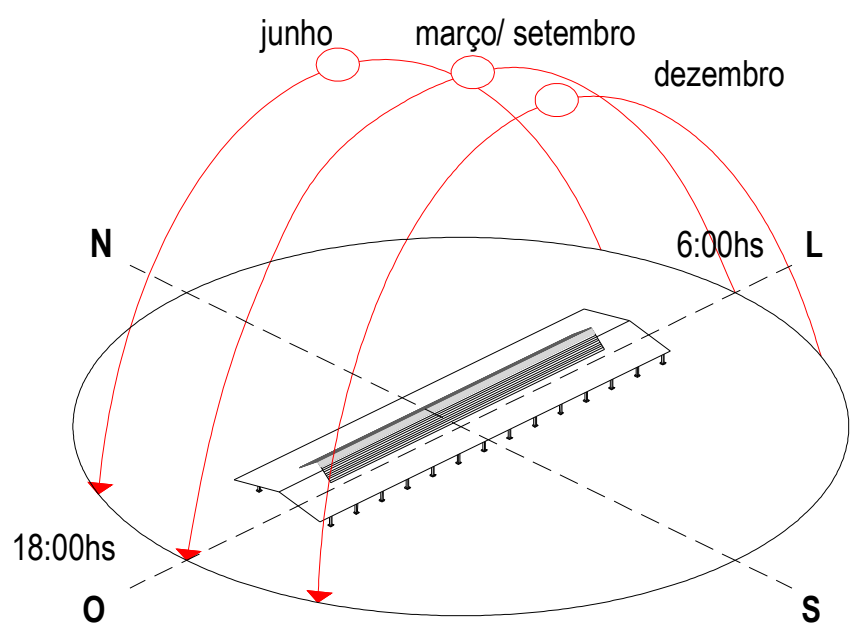

Figura 8.14: Esquema da trajetória aparente do sol sobre uma edificação da universidade

Pode-se observar a influência da incidência da radiação sobre um edifício-padrão de salas de aula da universidade através do desenho da sombra formada pela cobertura principal, em dois momentos distintos: solstício de verão e de inverno. Percebe-se que apenas no inverno a radiação incide diretamente sobre uma pequena área das salas de aula.

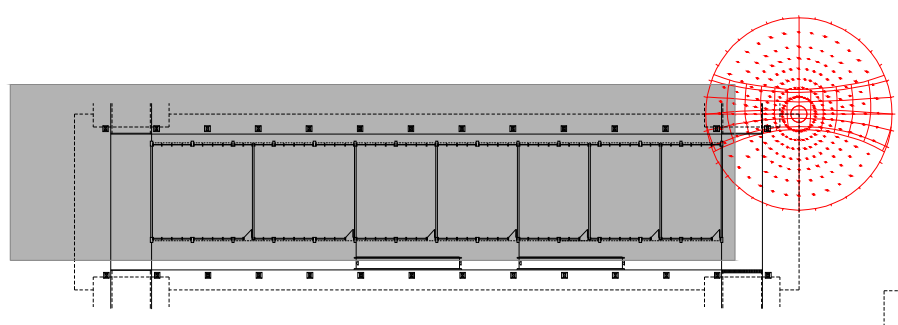

solstício de verão - 8 horas

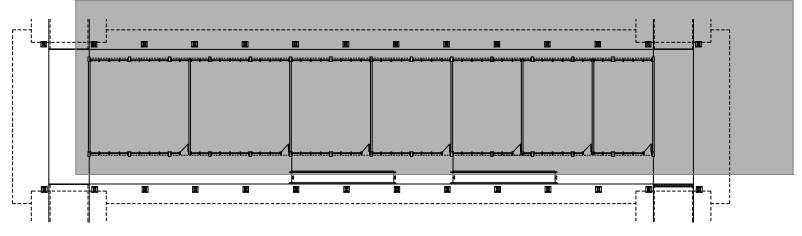

solstício de verão - 16 horas

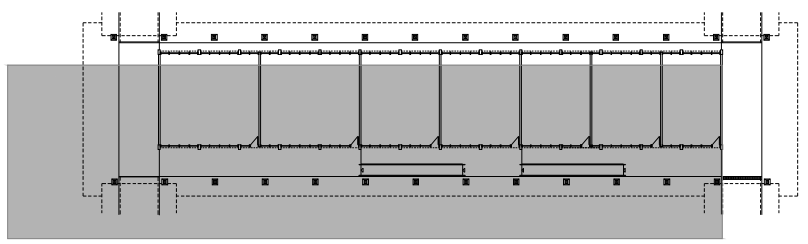

solstício de inverno - 8 horas

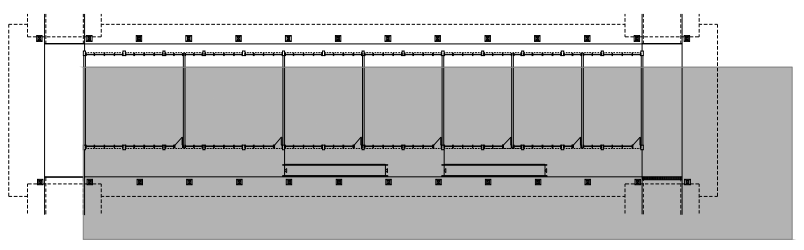

solstício de inverno - 16 horas

Figura 8.15: Projeção da sombra da cobertura em duas épocas distintas do ano para um bloco de salas de aula 
Ao analisar as propriedades térmicas da telha de fibrocimento utilizada na cobertura, observa-se que é um material leve, que possui elevada condutividade térmica $-\lambda=0,95 \mathrm{~W} /(\mathrm{m} . \mathrm{K})$ - e baixa capacidade térmica $-c=0,84 \mathrm{~kJ} /(\mathrm{kg} . \mathrm{K}$ ) (ABNT NBR 15220, 2003), ou seja, transmite grande quantidade de calor. Este fator se agrava com o enegrecimento que sofre com o passar do tempo, que em Manaus ocorre rapidamente devido à elevada umidade. Sem pintura, a telha fica enegrecida num período de três a seis meses; a pintura dura cerca de dois anos, e possibilita melhor resultado em termos de conforto térmico. Portanto, com o objetivo de melhorar sua resposta térmica, Porto indicou a pintura freqüente da cobertura em cores claras, visto que auxilia na redução da absorção da radiação incidente - a absortância para radiação solar do branco é de $20 \%$, enquanto do preto é de $97 \%$ (ABNT NBR 15220, 2003).

\subsubsection{Ventilação natural}

A ventilação natural dos ambientes, imprescindivel para o clima quente e úmido, foi trabalhada com atenção especial, visando fornecer maior conforto térmico aos usuários e limitar ao máximo o uso de ar condicionado, preocupação também aliada aos futuros custos da universidade. O projeto possui malha de implantação em cota elevada do terreno e obliqua aos ventos dominantes Nordeste $\left(45^{\circ}\right)$. Desníveis entre os blocos decorrentes da implantação sem muitas alterações na topografia visam permitir que 0 vento atinja todos os prédios. Os jardins entre os blocos possuem cerca de $20 \mathrm{~m}$ de largura, o que é espaço suficiente para que haja uma boa circulação do ar.

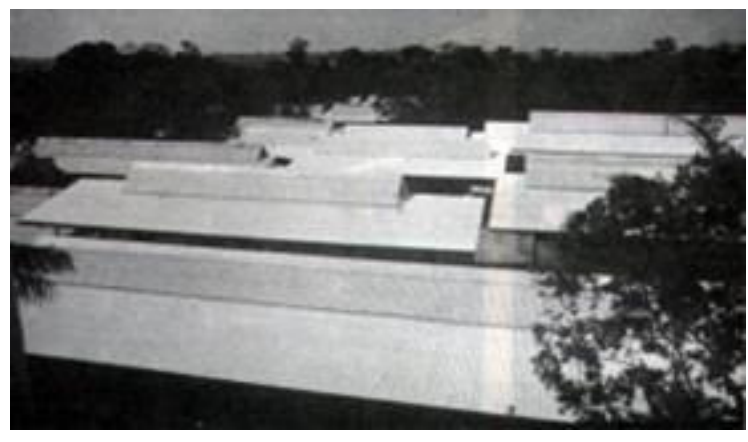

Figura 8.16: Vista do desnível entre as coberturas dos edifícios (PENTEADO et al, 1986)

A cobertura de estrutura metálica é independente dos ambientes fechados, formando um colchão de ar ventilado entre as telhas de fibrocimento e o forro de concreto. A cobertura de telhado inclinado 
favorece a extração do ar quente pela cumeeira, através da disposição de lanternins com aberturas na face Sul - lado oposto aos ventos - que oferecem proteção contra as chuvas e propiciam a saída por sucção (efeito chaminé) do ar aquecido que se encontre sob o telhado e dentro das salas.

O resultado plástico do conjunto é uma sucessão de edifícios térreos e assobradados, protegidos por amplos beirais de sombreamento e defesa contra chuva, e percursos igualmente protegidos explorando um animado jogo de coberturas, propícias às trajetórias da brisa. (CBA, 1991)

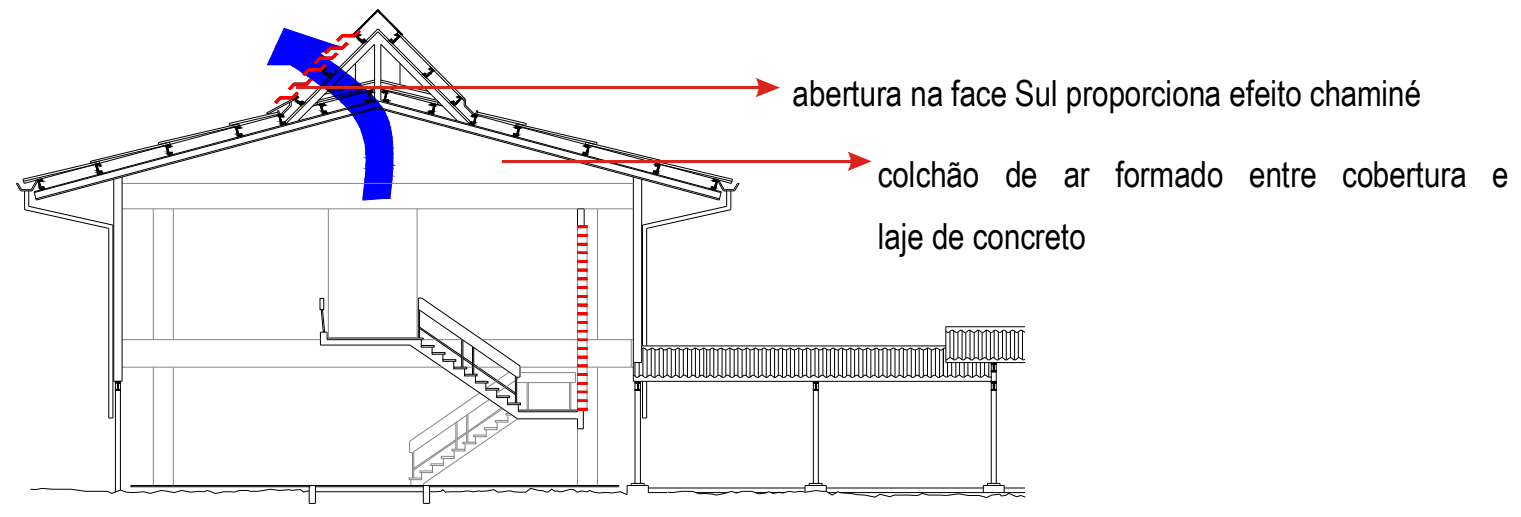

Figura 8.17: Corte transversal de um bloco da administração

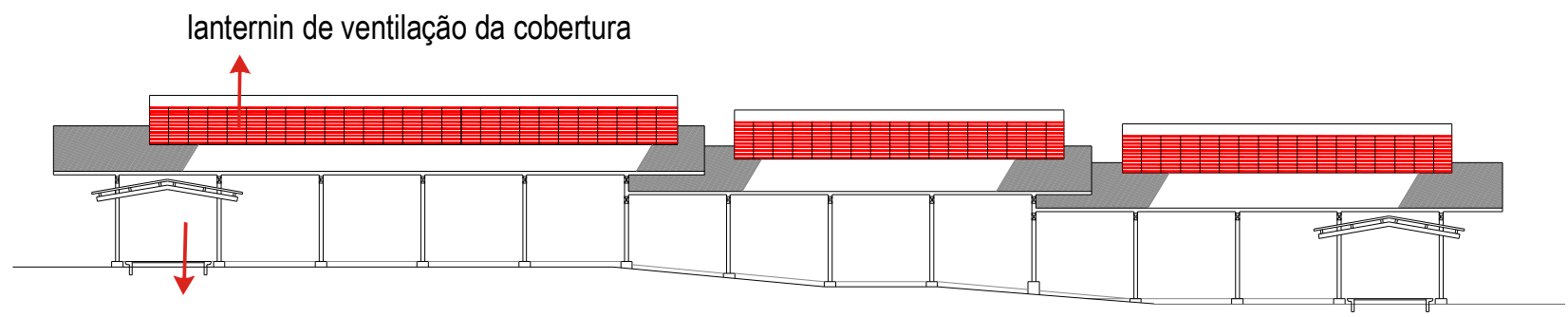

cobertura de ligação entre os blocos

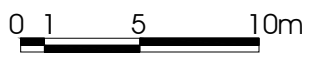

Figura 8.18: Fachada Sul do bloco de salas de aula

Os beirais grandes das coberturas combinam funções de proteção da radiação solar e das chuvas, bem como podem auxiliar no movimento de ar, já que eles podem aumentar a diferença de pressão entre fachadas opostas e, conseqüentemente, desviar o movimento de ar para dentro da edificação. 


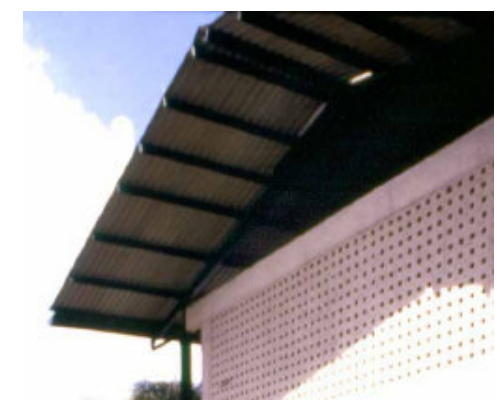

Figura 8.19: Detalhe dos beirais e elementos vazados (SABBAG, 2003)

Existem duas tipologias básicas de blocos na universidade: os blocos de dois pavimentos, que incluem laboratórios e administração, e os blocos de um pavimento, de salas de aula. Ambos possuem forma alongada, o que responde melhor à demanda de ventilação cruzada, e os corredores de circulação estão situados no lado contrário à direção dos ventos dominantes, para proteção da chuva. Os jardins dispostos entre as edificações auxiliam no controle do movimento de ar e resfriam o fluxo de ar que penetra na edificação.
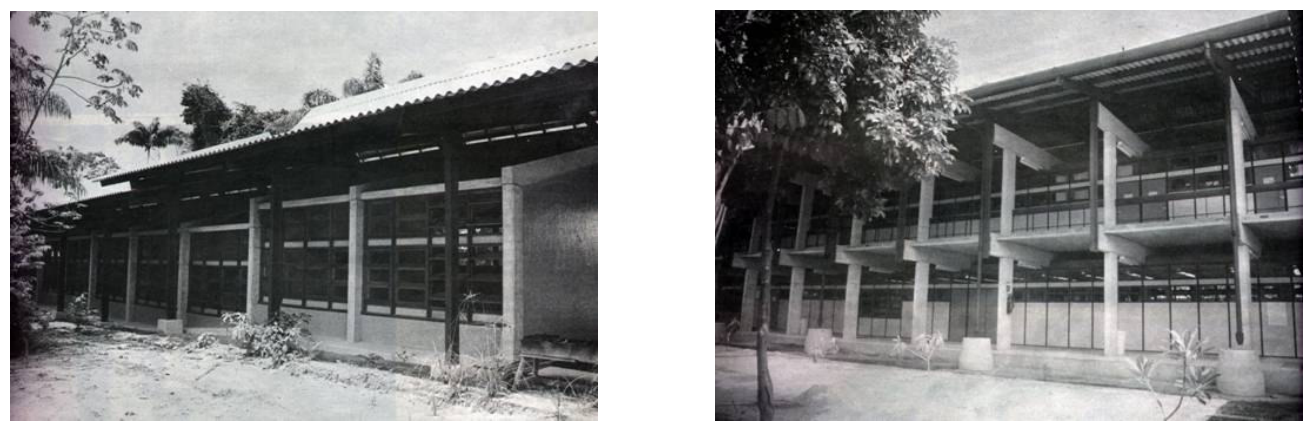

Figuras 8.20 e 8.21: Blocos de um e dois pavimentos, respectivamente (PENTEADO et al, 1986)

\subsubsection{Análise do bloco de dois pavimentos}

Nos blocos de dois pavimentos, os ambientes são fechados internamente por painéis modulados de divisória naval, compondo ora duas fileiras de salas com um corredor central, ora uma fileira com corredor lateral, dependendo do uso a que se destina. As caixas de escada são protegidas da radiação solar por elementos vazados, que permitem ventilação constante. 


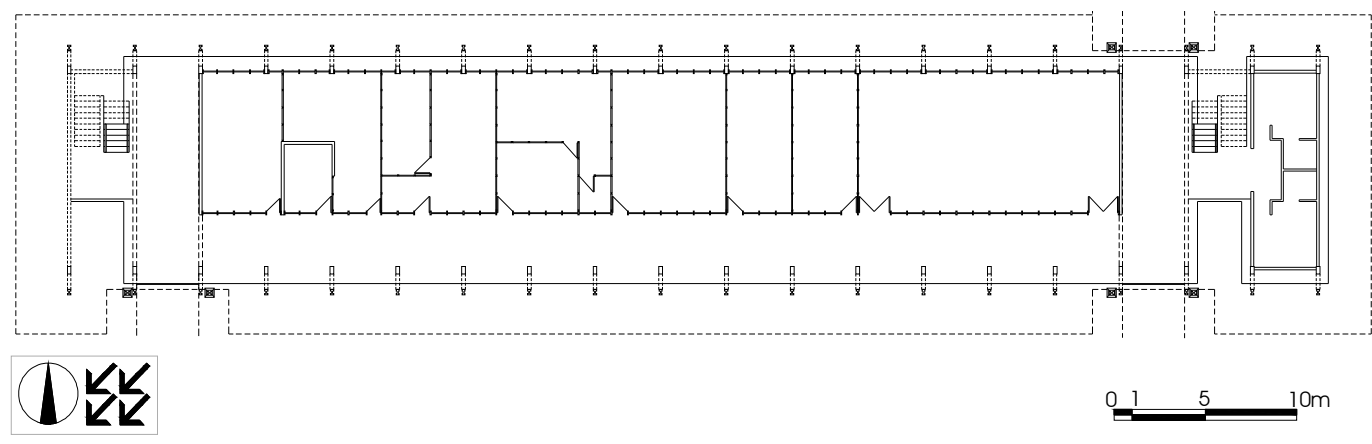

Figura 8.22: Planta de um bloco de administração - pavimento térreo

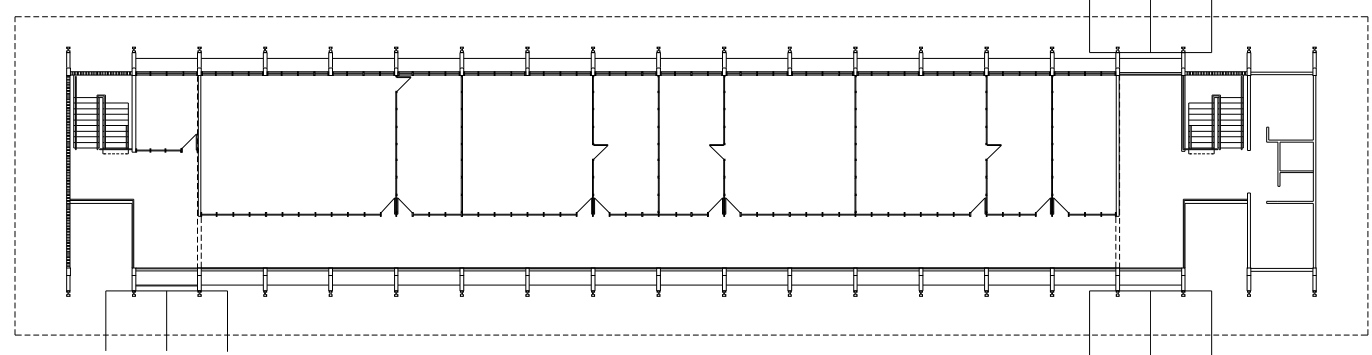

Figura 8.23: Planta - pavimento superior
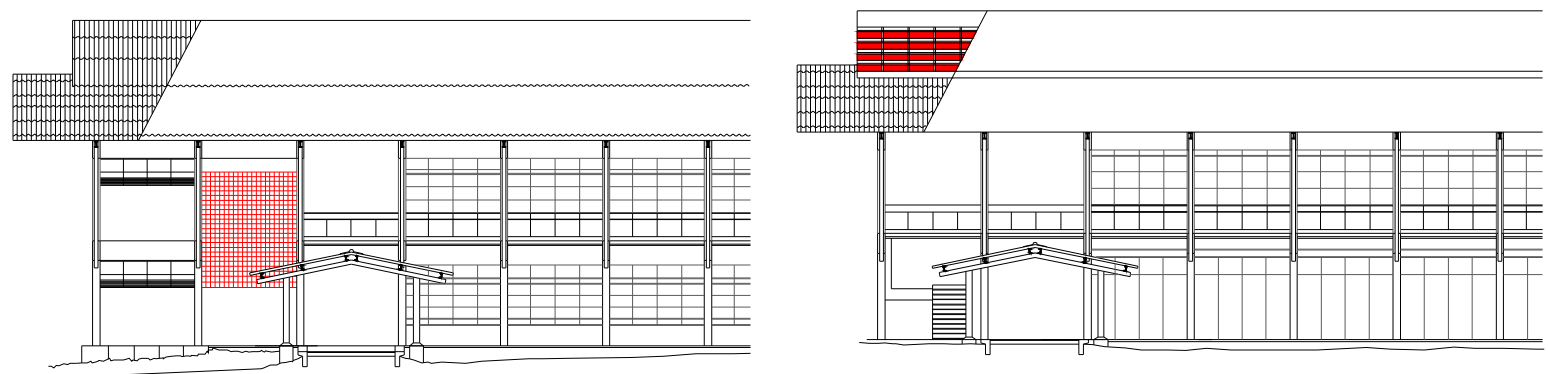

Figuras 8.24 e 8.25: Fachadas Norte e Sul, respectivamente

Estes blocos possuem sistema de ventilação que combina ventilação cruzada com efeito chaminé. No pavimento térreo, a estrutura metálica permite ventilação cruzada sobre a laje. No primeiro pavimento, além da ventilação cruzada sob a cobertura, existe um espaço de $2,5 \mathrm{~m}$ de altura na cumeeira do edifício, que permite a ocorrência de ventilação por efeito chaminé. $O$ ar mais quente pode sair pelas aberturas localizadas na fachada Sul da cobertura. $O$ desenho a seguir apresenta o esquema de ventilação: 


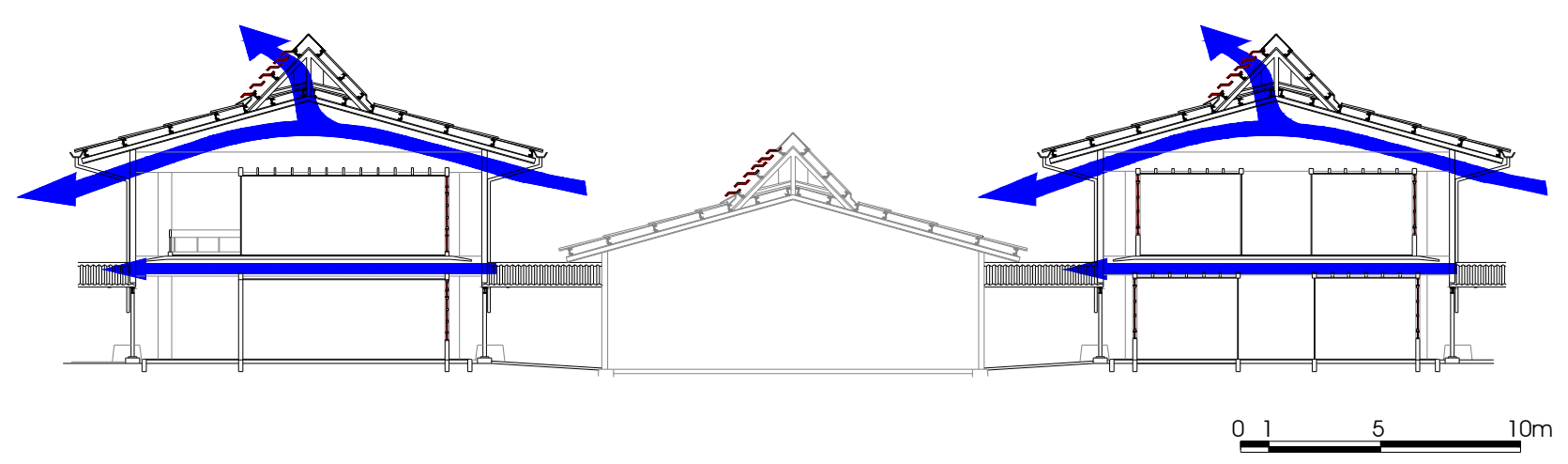

Figura 8.26: Corte transversal

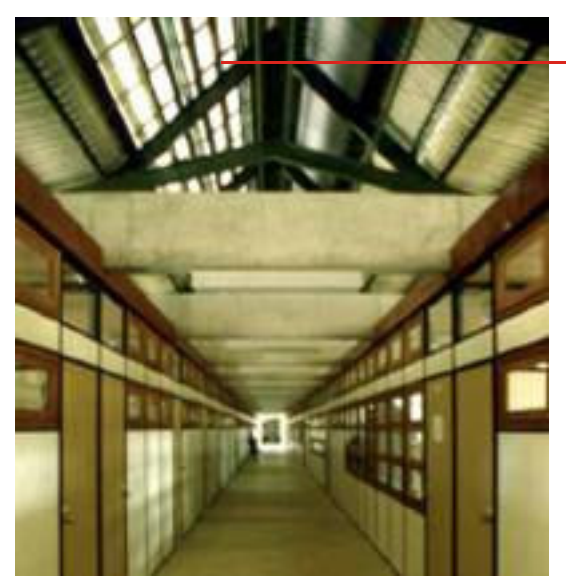

Figura 8.27: Circulação interna (SABBAG, 2003) espaço para circulação do ar entre o forro e a cobertura

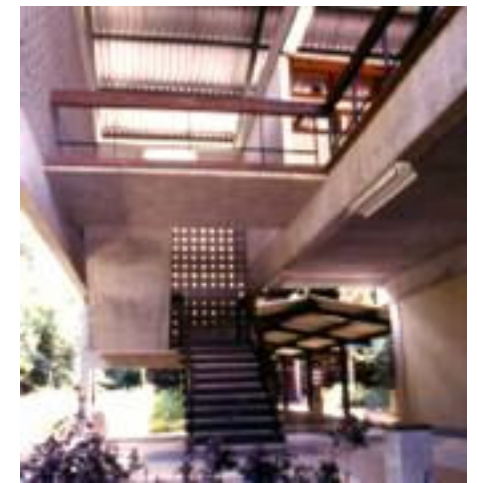

Figura 8.28: Circulação em contato com o exterior (SABBAG, 2003)

8.1.5.2 Análise do bloco de um pavimento: salas de aula

Os blocos de salas de aula possuem aberturas em fachadas opostas - Norte e Sul, o que garante a ocorrência de ventilação cruzada. $O$ vento chega inclinado a $45^{\circ}$ em relação ao plano da abertura de entrada, situada na face Norte, trazendo uma ventilação satisfatória, já que todo o ambiente é afetado pelo fluxo de ar, que se torna turbulento no espaço interno (figura 8.29). Tanto as aberturas de entrada como as de saída ocupam toda a extensão das fachadas, que podem ficar inteiramente abertas para exposição aos ventos. 


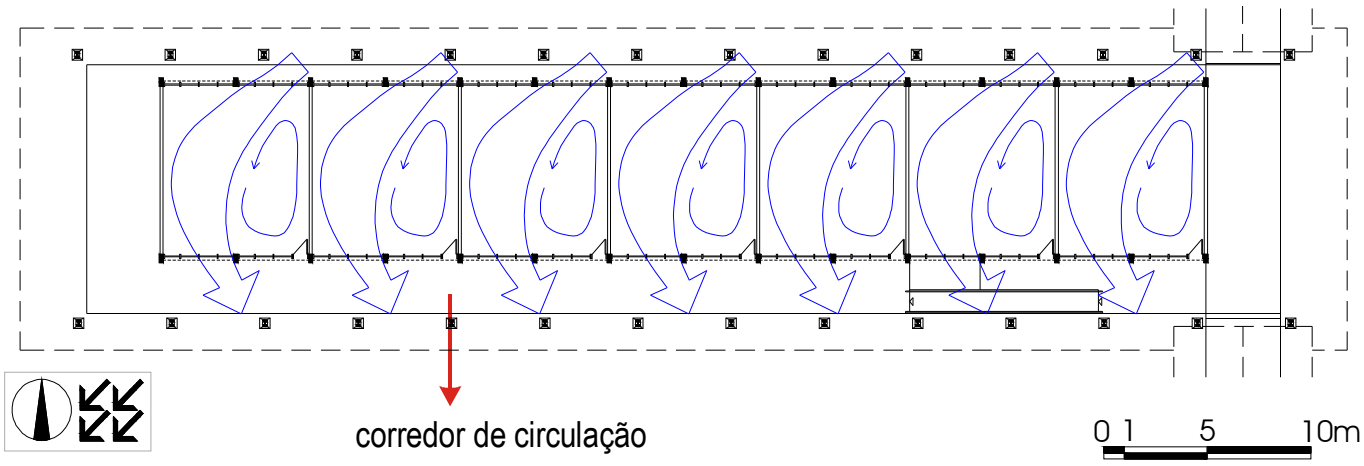

Figura 8.29: Planta do bloco de salas de aula - um pavimento

Este bloco, assim como o de dois pavimentos, possui ventilação cruzada associada ao efeito chaminé. Além das aberturas laterais existem aberturas zenitais, localizadas na laje de concreto das salas de aula, que funcionam em conjunto com o lanternin da cobertura, formando uma camada de ar móvel entre 0 forro e o telhado, que auxilia a dissipar o calor advindo da incidência de radiação sobre o telhado. A localização das aberturas zenitais mais próximas às aberturas laterais de saída do ar (em relação ao centro da laje) é um fator positivo, segundo Allard (1998), pois divide o fluxo entre as duas aberturas e não forma zona de sombra de vento. $O$ esquema de ventilação é o que se apresenta a seguir:

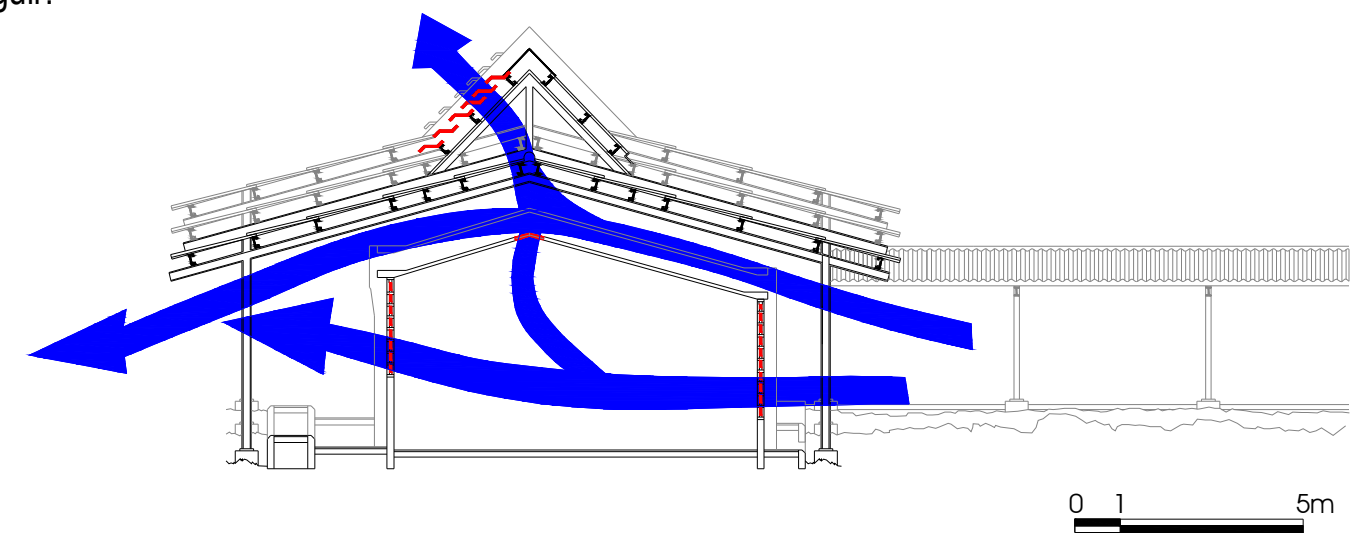

Figura 8.30: Corte transversal do bloco de salas de aula

As salas de aula possuem $8 \mathrm{~m}$ de comprimento por $7 \mathrm{~m}$ de largura, dando um total de $56 \mathrm{~m}^{2}$ de área. A face Norte possui pé-direito de $3,40 \mathrm{~m}$, a face Sul de $3,70 \mathrm{~m}$, e o pé-direito no ponto mais alto do ambiente (direção da cumeeira) é de $4,50 \mathrm{~m}$. O volume total da sala é de $221,2 \mathrm{~m}^{3}$. Sabe-se que um dos fatores mais importantes que determina a ocorrência de movimento de ar por diferença de temperatura é a distância vertical entre as aberturas de entrada e saída do ar. Nesta sala, a distância vertical entre as aberturas de entrada de ar (face Norte) e as aberturas zenitais é de 2,10m; um valor que não é 
satisfatório para que haja um gradiente razoável de temperatura, o que dificulta a ventilação por efeito chaminé.

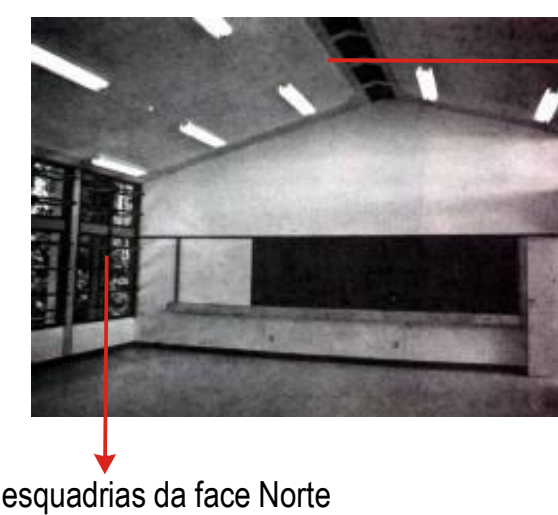

Figura 8.31: Vista interna da sala de aula (PENTEADO et al, 1986) abertura zenital

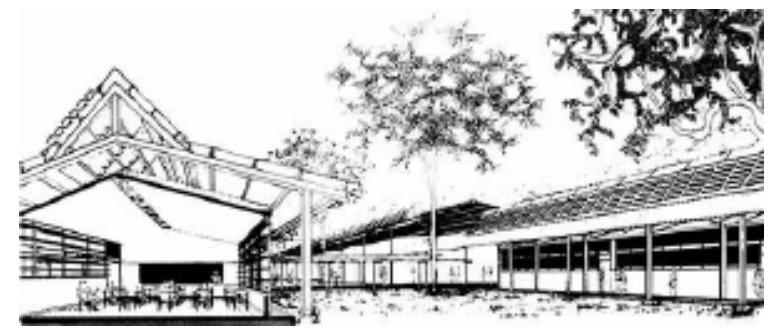

Figura 8.32: Perspectiva ido bloco de salas de aula (SABBAG, 2003)

A vedação da face Norte possui uma área de $23,8 \mathrm{~m}^{2}$, sendo que $17,6 \mathrm{~m}^{2}$, ou $74 \%$, correspondem à área de esquadrias. São quatro esquadrias de dimensões $1,60 \times 2,40 \mathrm{~m}$ cada, sendo que cada folha de vidro possui $0,40 \times 0,80 \mathrm{~m}$ e cada folha opaca possui $0,17 \times 0,80 \mathrm{~m}$ (figura 8.34). A face Sul possui uma área total de $25,9 \mathrm{~m}^{2}$ e uma área de esquadrias de $13,8 \mathrm{~m}^{2}$, ou $53,3 \%$. São três esquadrias de $1,60 \mathrm{x}$ $2,00 \mathrm{~m}$ cada (figura 8.35) e uma de $0,80 \times 2,00 \mathrm{~m}$. Tanto o posicionamento das aberturas (fachadas Norte e Sul) como a porcentagem em relação à área total das fachadas condizem com as recomendações dadas por Mahoney. Os desenhos das esquadrias apresentam-se a seguir:
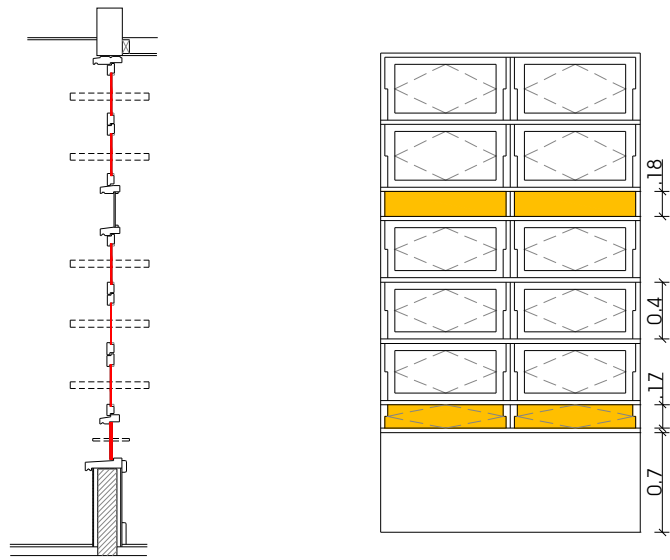

Figuras 8.33 e 8.34: Esquadria da fachada Norte - corte e vista

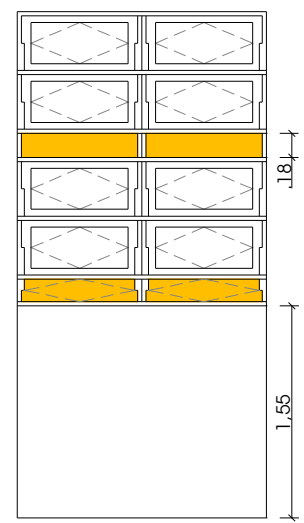

Figura 8.35: Esquadria da fachada Sul - vista 
Quanto à locação vertical, as aberturas de entrada do ar ocupam desde $0,70 \mathrm{~m}$ acima do piso até a altura da laje, permitindo que o vento atinja todo o ambiente interno, já que a janela de entrada é que determina o padrão do movimento de ar. As aberturas de saída são um pouco mais altas (1,55m acima do piso) e proporcionam um fluxo de ar ascendente, no nível dos usuários, de acordo com o que Mahoney indica.

As aberturas são do tipo pivotantes horizontais, o que dá possibilidade ao usuário de regular a direção do fluxo de ar e permite até $100 \%$ de área real de abertura. As esquadrias oferecem mecanismos separados de abertura das folhas opacas (amarelas) e transparentes, sendo que as folhas de vidro incolor possuem um sistema único de abertura, acionado por manivela localizada na extremidade inferior; as folhas amarelas abrem-se individualmente.

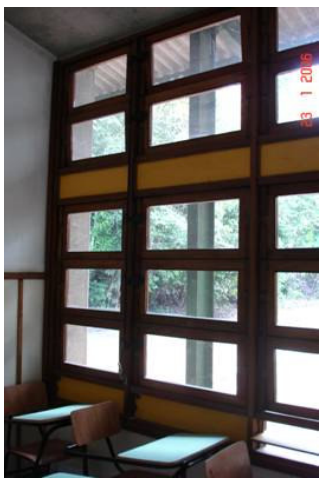

Figuras 8.36 e 8.37: Esquadria da face Nortefechada e aberta
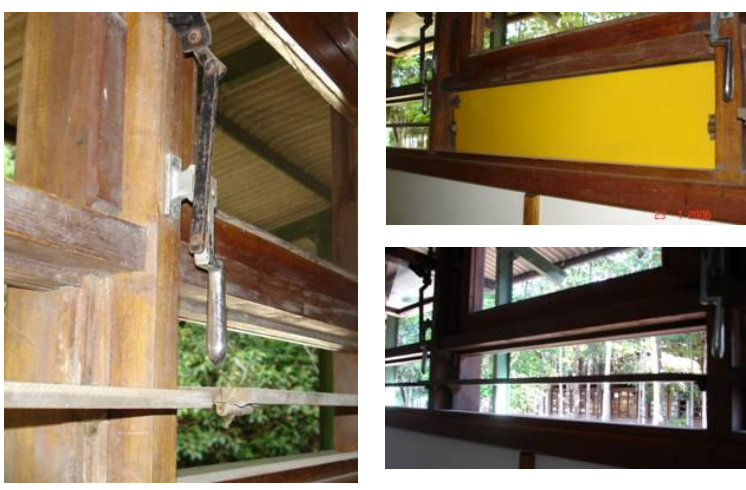

Figuras 8.38 a 8.40 : Sistemas de abertura das folhas de vidro e opacas

O resultado final da universidade foi um projeto simples, que procurou evitar ao máximo 0 desmatamento e o desequilíbrio ecológico da área. Segundo o próprio Severiano, o projeto criou um padrão forte para a universidade, e conseguiu adequar-se ao clima da região (PORTO, 2005; informação verbal). Sua qualidade está no trabalho constante de soluções que buscam condições naturais de conforto, sempre integradas ao ambiente circundante. $O$ uso da ventilação cruzada aliada ao efeito chaminé é uma boa estratégia para obtenção de conforto térmico em cidades como Manaus, de clima quente e úmido e com ventos de velocidades baixas, e é um elemento bastante trabalhado nesta obra. Porém, a pequena diferença de altura entre as aberturas de entrada e saída do ar dificulta a circulação por efeito chaminé. 


\subsubsection{A Universidade hoje}

A pesquisa de campo trouxe dados importantes para a avaliação de aspectos relativos ao entorno da obra e à preservação da vegetação local, além do estado de conservação atual dos prédios, reformas e modificações efetuadas, que serão aqui apresentados.

O platô onde se encontra implantado o conjunto de edifícios do campus ainda é cercado por mata nativa fechada, que auxilia na manutenção de um microclima mais estável, já que a superfície vegetal possui albedo baixo, porém possui a desvantagem de barrar o fluxo de ar natural, reduzindo a exposição aos ventos dominantes locais.
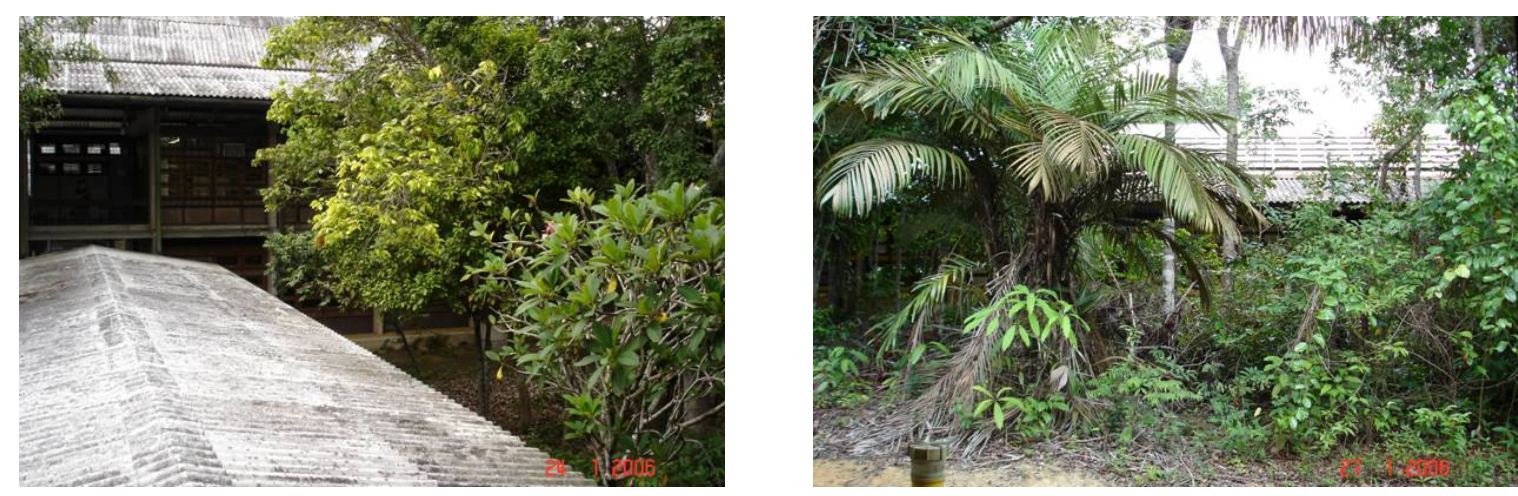

Figuras 8.41 e 8.42: Edifícios do campus cercados de mata nativa

Os ambientes externos cobertos funcionam de acordo com o projeto original, tanto áreas para refeição e lanchonetes como áreas de circulação e estar. Já os ambientes internos foram todos adaptados para instalação de ar condicionado. Segundo informações obtidas pelos usuários das edificações, a presença de insetos, principalmente no período noturno, e o calor excessivo demandaram a instalação de equipamentos de refrigeração artificial, e atualmente não há ambientes fechados na Universidade que não disponham de tais aparelhos. Para a realização desta modificação, foram vedadas as aberturas no forro das salas de aula, interrompendo o fluxo de ar pela cobertura. 

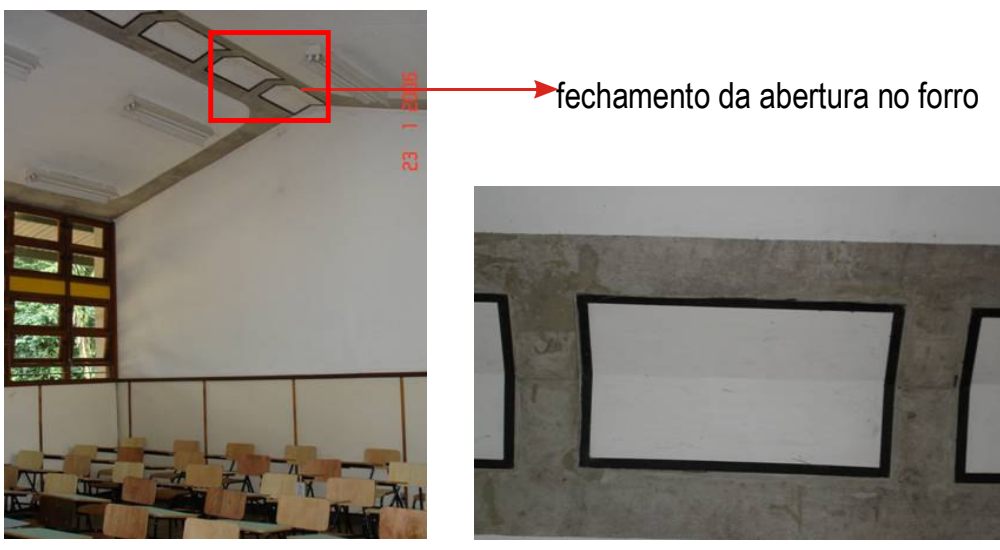

Figuras 8.43 e 8.44: Vedação das aberturas no forro das salas de aula

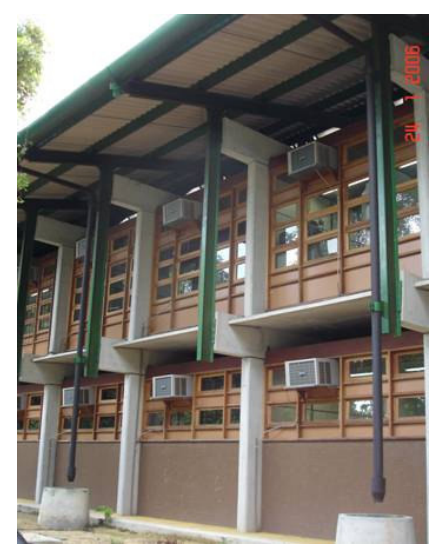

Figura 8.45: Instalação de aparelhos de ar condicionado nos edifícios

O estado geral de conservação atual dos edifícios é relativamente bom. Alguns problemas de manutenção interferem diretamente no desempenho térmico do conjunto, como o enegrecimento da telha de fibrocimento, que aumenta a absorção de radiação solar e contribui para um maior aquecimento dos ambientes cobertos. Também há problemas no funcionamento das esquadrias, já que o sistema de abertura de algumas delas encontra-se quebrado, prejudicando a circulação de ar natural quando o ar condicionado encontra-se desligado. Como o sistema é único para todas as folhas, quando está quebrado impede a abertura da esquadria toda, o que reduz significativamente a área de abertura total da vedação. A instalação do equipamento de refrigeração também prejudicou o sistema de ventilação natural, pois uma esquadria inteira que se encontra atrás do aparelho não pode mais ser aberta.

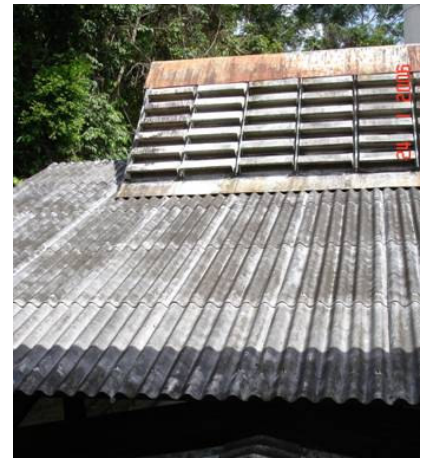

Figura 8.46: Telha de fibrocimento enegrecida

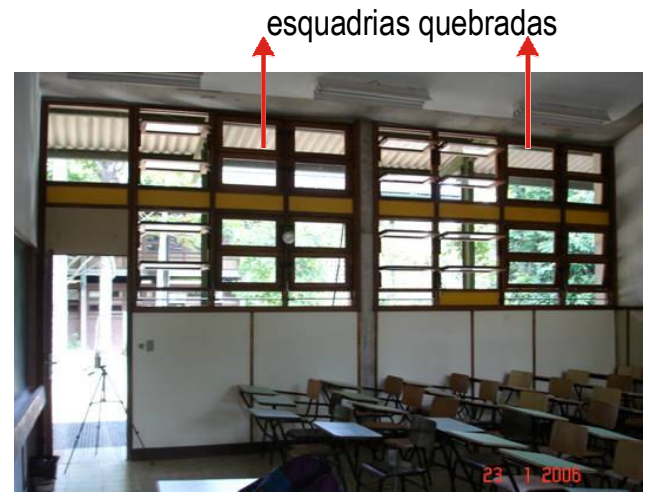

Figura 8.47: Sistema de abertura quebrado, em esquadrias de uma sala de aula 
A Universidade encontra-se em expansão e há diversos edifícios novos sendo construídos, todos acompanhando 0 projeto original de Porto, sob supervisão do próprio arquiteto ${ }^{23}$, com algumas modificações para adaptar-se à exigência atual de instalação de ar condicionado.

\subsection{ANÁLISE QUANTITATIVA}

A pesquisa de campo para medições das variáveis térmicas foi realizada na Faculdade de Tecnologia da Universidade, na semana de 23 a 30 de janeiro de 2006. As medições de temperatura e umidade foram realizadas ininterruptamente pelo período de uma semana, em intervalos de 15 minutos. Os equipamentos de medição foram dispostos nos seguintes pontos: os pontos 1 a 3 dentro das salas de aula 207 e 204 (situadas uma na extremidade e outra no centro do bloco de salas de aula), o ponto 4 na caixa de escadas do bloco de administração, o ponto 5 no jardim entre as edificações (figura 8.48). Todos os pontos localizavam-se em áreas cobertas, protegidos da chuva e da radiação solar direta.

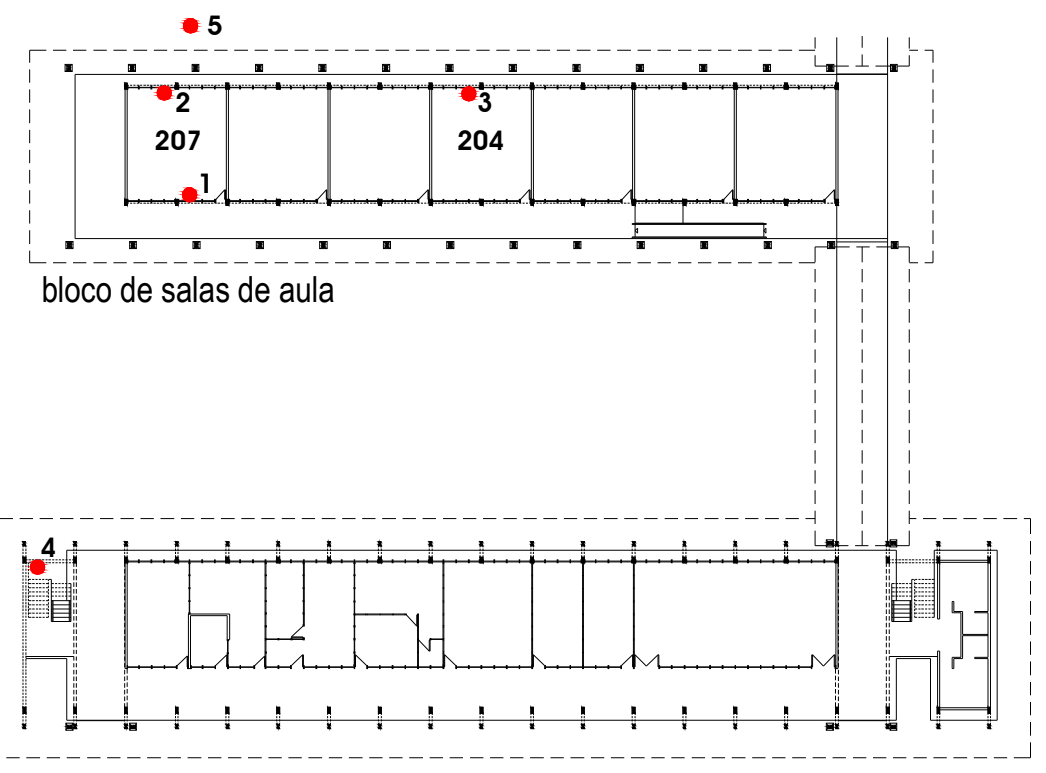

治 bloco de administração

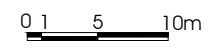

Figura 8.48: Indicação em vermelho de onde foram instalados os equipamentos de medição de temperatura e umidade

23 Informação verbal, fornecida por Severiano Porto durante entrevista realizada em março de 2005. 
O bloco de salas de aula foi escolhido para uma análise mais detalhada da ventilação natural. Por isso, as medições de velocidade do ar foram realizadas nas duas salas de aula, 207 e 204, onde os anemômetros foram instalados em horários alternados, durante cinco dias da semana. Para uma leitura adequada dos resultados obtidos, faz-se necessária uma descrição minuciosa sobre as condições de monitoramento destes ambientes, realizada a seguir.

\subsubsection{Caracterização dos ambientes escolhidos para análise}

As duas salas possuem aparelho de ar condicionado, que se encontravam fora de funcionamento na semana da pesquisa. Contam com 14 luminárias, com duas lâmpadas fluorescentes cada, que ficam acesas em todas as aulas, inclusive durante 0 dia. Este dado mostra um problema grave, já que a luz natural deveria ser suficiente para garantir uma boa iluminação interna, sem a necessidade de lâmpadas acesas durante o dia, que podem contribuir para o aquecimento do ambiente interno. De acordo com Frota e Schiffer (1995), lâmpadas fluorescentes convertem 25\% de sua potência elétrica em luz, $25 \%$ se dissipa sob a forma de calor radiante e $50 \%$ se dissipa por convecção e condução. São, portanto, uma importante fonte geradora de calor para o ambiente interno.

Cada sala possui 60 carteiras de madeira para estudantes e uma mesa com cadeira para o professor. A seguir, imagens da sala 207 (figuras 8.49 a 8.51) e a tabela 8.1, que apresenta uma especificação detalhada de materiais e revestimentos utilizados na construção do bloco de salas de aula, dados necessários para avaliação do desempenho térmico da edificação.
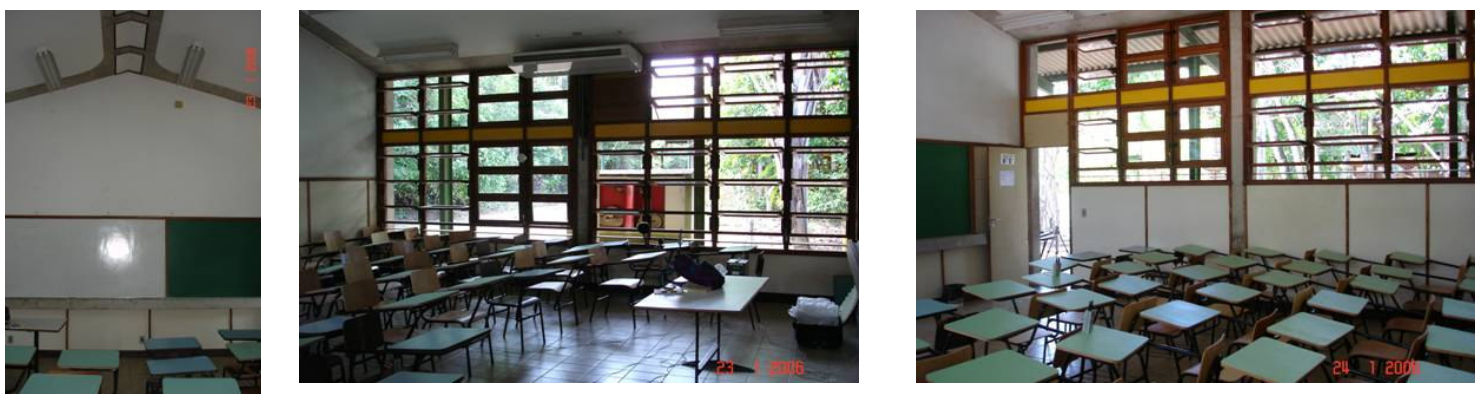

Figuras 8.49 a 8.51: Sala de aula 207 - interior, vedações Norte e Sul, respectivamente 
Tabela 8.1 - Materiais construtivos e revestimentos do bloco de salas de aula

\begin{tabular}{|l|l|}
\hline \multicolumn{1}{|c|}{ Componente do edifício } & \multicolumn{1}{c|}{ Material } \\
\hline Cobertura independente & Telha de fibrocimento \\
\hline Estrutura da cobertura & Metálica, pintada de verde \\
\hline Estrutura das salas de aula & Concreto aparente \\
\hline Vedação das salas de aula & Tijolo cerâmico vazado $(e s p . ~ 20 \mathrm{~cm})$ \\
\hline Revestimento externo da vedação & Pastilha cerâmica \\
\hline Revestimento interno da vedação & Fórmica bege até altura de 1,80m \\
\hline Revestimento do piso & Cerâmica \\
\hline Forro & Laje de concreto pintada de branco \\
\hline Esquadrias & Madeira e vidro incolor comum \\
\hline
\end{tabular}

\subsubsection{Sala 207}

A sala 207 apresentava, durante o monitoramento, o sistema de abertura das folhas de vidro quebrado em três esquadrias, uma na face Norte e duas na face Sul (indicados na figura 8.52), que não puderam ser abertas neste período. As outras esquadrias e todas as folhas opacas (amarelas), que se abrem separadamente, estavam abertas para as medições. A porta também foi mantida constantemente aberta.

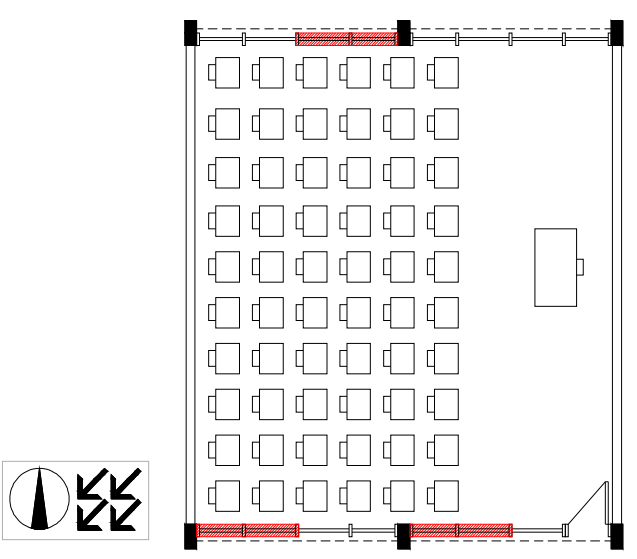

Figura 8.52: Sala de aula 207 - indicação de esquadrias quebradas

As aulas que ocorreram nesta sala no período possuíam turma de 30 a 40 pessoas, além do professor. A tabela abaixo indica os dias e horários em que a sala foi utilizada durante a semana de medições. Durante estes períodos, as luzes encontravam-se acesas. É importante salientar que os dados apresentados na tabela não especificam os períodos de intervalo entre as aulas. 
Tabela 8.2: Dias e horários de aula na sala 207

\begin{tabular}{|c|c|c|c|c|}
\hline Seg (23/01) & Ter (24/01) & Qua (25/01) & Qui (26/01) & Sex (27/01) \\
\hline $7-9 \mathrm{hs}$ & $7-9 \mathrm{hs}$ & $7-9 \mathrm{hs}$ & $7-9 \mathrm{hs}$ & $7-9 \mathrm{hs}$ \\
\hline $9-11 \mathrm{hs}$ & $9-11 \mathrm{hs}$ & $9-11 \mathrm{hs}$ & $9-11 \mathrm{hs}$ & $11-13 \mathrm{hs}$ \\
\hline $12-13 \mathrm{hs}$ & $11-13 \mathrm{hs}$ & $12-15 \mathrm{hs}$ & $11-13 \mathrm{hs}$ & $13-15 \mathrm{hs}$ \\
\hline $15-17 \mathrm{hs}$ & $13-15 \mathrm{hs}$ & $15-17 \mathrm{hs}$ & $13-16 \mathrm{hs}$ & - \\
\hline $17-19 \mathrm{hs}$ & $17-19 \mathrm{hs}$ & $17-19 \mathrm{hs}$ & $17-20 \mathrm{hs}$ & - \\
\hline
\end{tabular}

\subsubsection{Sala 204}

Esta sala possuía o sistema de abertura de duas esquadrias quebrado, uma na face Norte e uma na face Sul, conforme indicação da figura a seguir. As outras esquadrias, todas as folhas amarelas e a porta foram mantidas constantemente abertas. A tabela 8.3 indica os períodos de aulas, com o mesmo número de alunos da sala anterior.

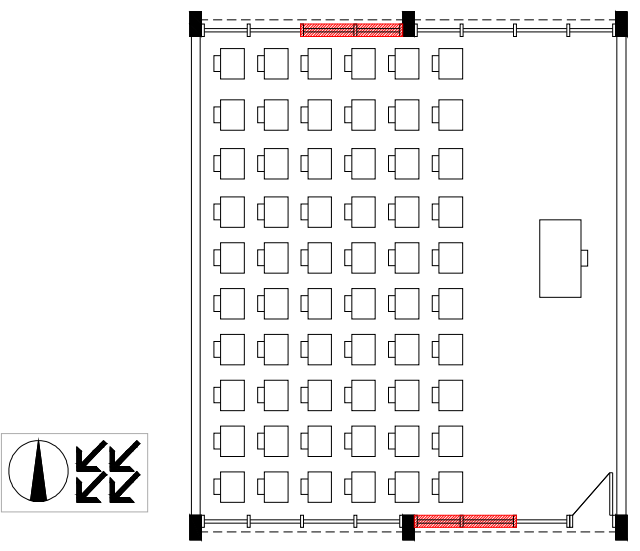

Figura 8.53: Sala de aula 204 - indicação de esquadrias quebradas

Tabela 8.3 - Dias e horários de aula na sala 204

\begin{tabular}{|c|c|c|c|c|c|}
\hline Seg (23/01) & Ter (24/01) & Qua (25/01) & Qui (26/01) & Sex (27/01) & Sábado (28/01) \\
\hline $7-9 \mathrm{hs}$ & $7-9 \mathrm{hs}$ & $7-9 \mathrm{hs}$ & $7-9 \mathrm{hs}$ & $7-9 \mathrm{hs}$ & $9-11 \mathrm{hs}$ \\
\hline $9-12 \mathrm{hs}$ & $9-11 \mathrm{hs}$ & $9-12 \mathrm{hs}$ & $9-11 \mathrm{hs}$ & $9-11 \mathrm{hs}$ & - \\
\hline $13-15 \mathrm{hs}$ & $11-13 \mathrm{hs}$ & $13-15 \mathrm{hs}$ & $13-15 \mathrm{hs}$ & $15-17 \mathrm{hs}$ & - \\
\hline $15-17 \mathrm{hs}$ & $13-15 \mathrm{hs}$ & $15-17 \mathrm{hs}$ & $15-17 \mathrm{hs}$ & - & - \\
\hline $17-19 \mathrm{hs}$ & $15-17 \mathrm{hs}$ & $17-19 \mathrm{hs}$ & $18-20 \mathrm{hs}$ & - & - \\
\hline- & $18-20 \mathrm{hs}$ & - & - & - & - \\
\hline
\end{tabular}

\subsubsection{Dados obtidos para temperatura e umidade}

A seguir, são apresentados dois gráficos: o gráfico 8.1 refere-se aos dados de temperatura externa e interna (sala 207) e o gráfico 8.2 refere-se aos dados de umidade externa e interna. 


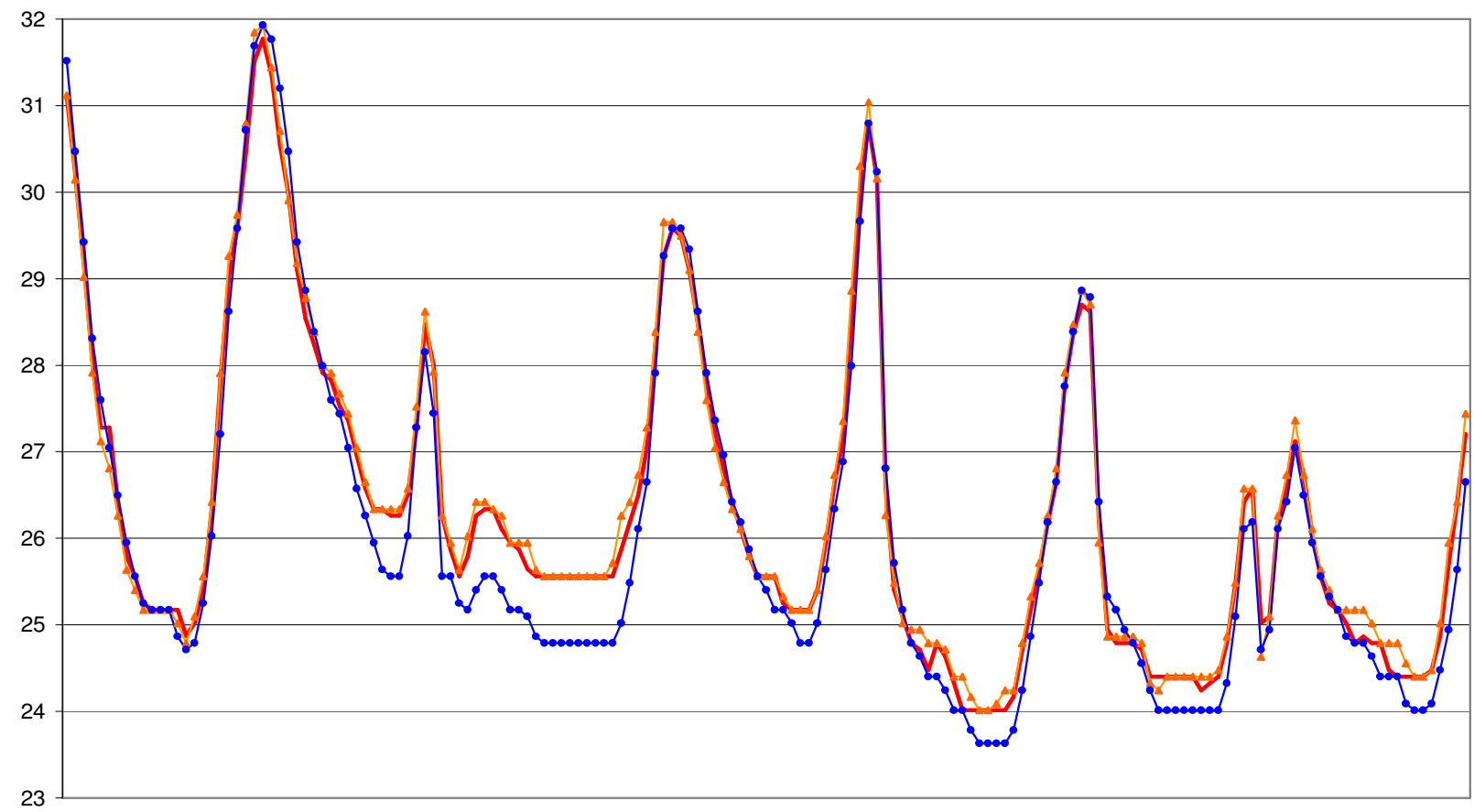

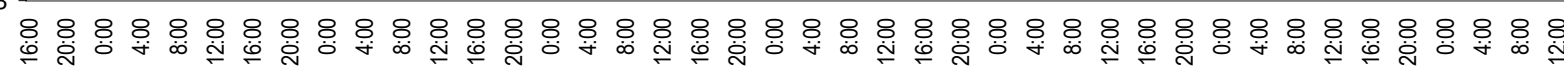

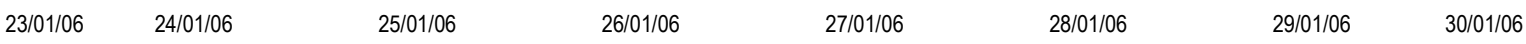

— sala 207 (face Norte) Temp. $\left({ }^{*} \mathrm{C}\right) \multimap$ sala 207 (face Sul) Temp. $\left({ }^{*} \mathrm{C}\right) \multimap-$ externo Temp. $\left({ }^{\star} \mathrm{C}\right)$

Gráfico 8.1: Temperatura do $\operatorname{ar}\left({ }^{\circ} \mathrm{C}\right)$ - interno (sala 207) x externo

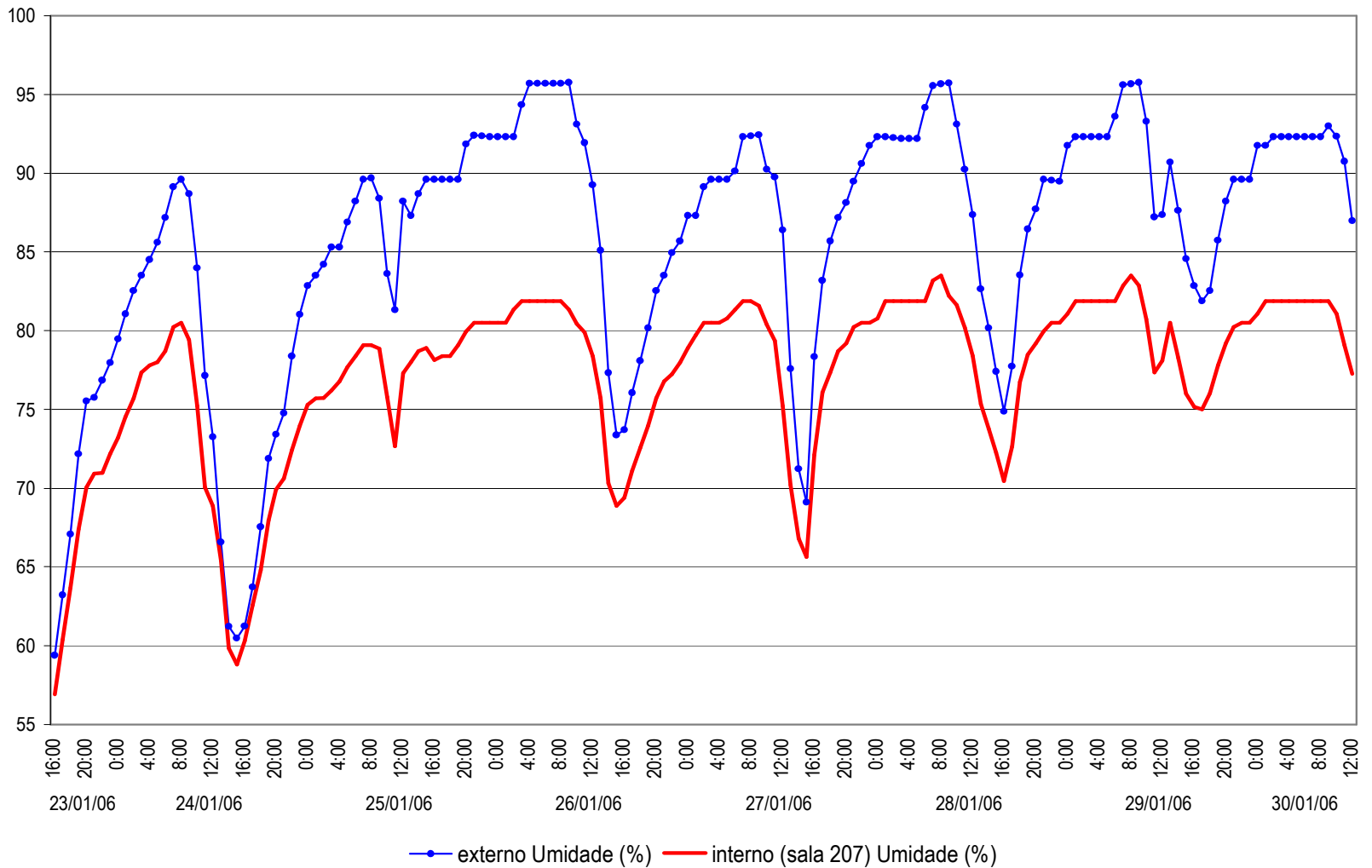

Gráfico 8.2: Umidade relativa do ar (\%) - interno (sala 207) x externo 
As medidas de temperatura externa obtidas mostram uma pequena oscilação durante o dia, o que é característica do clima quente e úmido da região, devido à umidade elevada. No período de uma semana, o pico máximo registrado foi de $31,93^{\circ} \mathrm{C}$ às $14 \mathrm{~h}$ (dia $24 / 01$ ); neste mesmo dia a temperatura mínima registrada foi de $24,4^{\circ} \mathrm{C}$ às $06 \mathrm{~h} 30 \mathrm{~min}$, o que deu uma amplitude de $7,5^{\circ} \mathrm{C}$, entre o período mais quente e o mais frio do dia. Esta variação apresentou valores ainda menores para os outros dias: $3,5^{\circ} \mathrm{C}$ no dia $25 / 01,4,7^{\circ} \mathrm{C}$ dia $26 / 01,6,3^{\circ} \mathrm{C}$ dia $27 / 01,5,5^{\circ} \mathrm{C}$ dia $28 / 01$ e $3,1^{\circ} \mathrm{C}$ dia $29 / 01$. Os picos máximos ocorreram por volta das duas horas da tarde, o que determina o período mais quente do dia, já os mínimos ocorreram pouco antes do nascer do sol, como pode ser observado no gráfico 8.1. A média semanal ficou em $26,1^{\circ} \mathrm{C}$.

A umidade externa manteve-se constantemente alta, sendo a média semanal de 90,0\%, um valor extremamente elevado, comum para a época em que foram realizadas as medições, de chuva na região e de cheia dos rios. Ao comparar os valores obtidos externamente com os valores de umidade interna, observa-se a grande diferença de resultados (gráfico 8.2). A umidade externa manteve-se constantemente mais elevada do que a interna, chegando a diferenças de $13 \%$ para os picos máximos, o que provavelmente se deve ao fato das medições externas terem sido realizadas no jardim existente entre as edificações, em contato muito próximo com a vegetação. O processo de evapo-transpiração das plantas pode elevar a umidade do ar no local, o que pode ter contribuído para a diferença apresentada. A média semanal de umidade interna ficou em $77,3 \%$.

Comparando a variação da temperatura interna da sala de aula 207 com a variação da temperatura externa (gráfico 8.1), observa-se que praticamente não houve amortecimento nem atraso térmico. 0 amortecimento pode ser definido como a razão entre a amplitude externa e a interna. Assim, apenas uma pequena diferença pôde ser encontrada entre os valores externos e internos de temperatura mínima, que chegou a um valor máximo de $0,8^{\circ} \mathrm{C}$ (dia $25 / 01$ às $20 \mathrm{~h}$ ), o que revela um amortecimento mínimo de temperatura. A média da temperatura interna foi pouco superior à externa: $26,3^{\circ} \mathrm{C}$. 0 atraso térmico não foi superior a 45 minutos, sendo que em alguns dias os picos máximos de temperatura externa e interna ocorreram no mesmo horário, e eventualmente os picos internos chegaram até a ocorrer antes dos externos. Isto pode ocorrer devido a alguns fatores específicos do ambiente, como a presença de usuários (períodos de aula) e o uso de iluminação artificial, duas fontes internas de calor. 


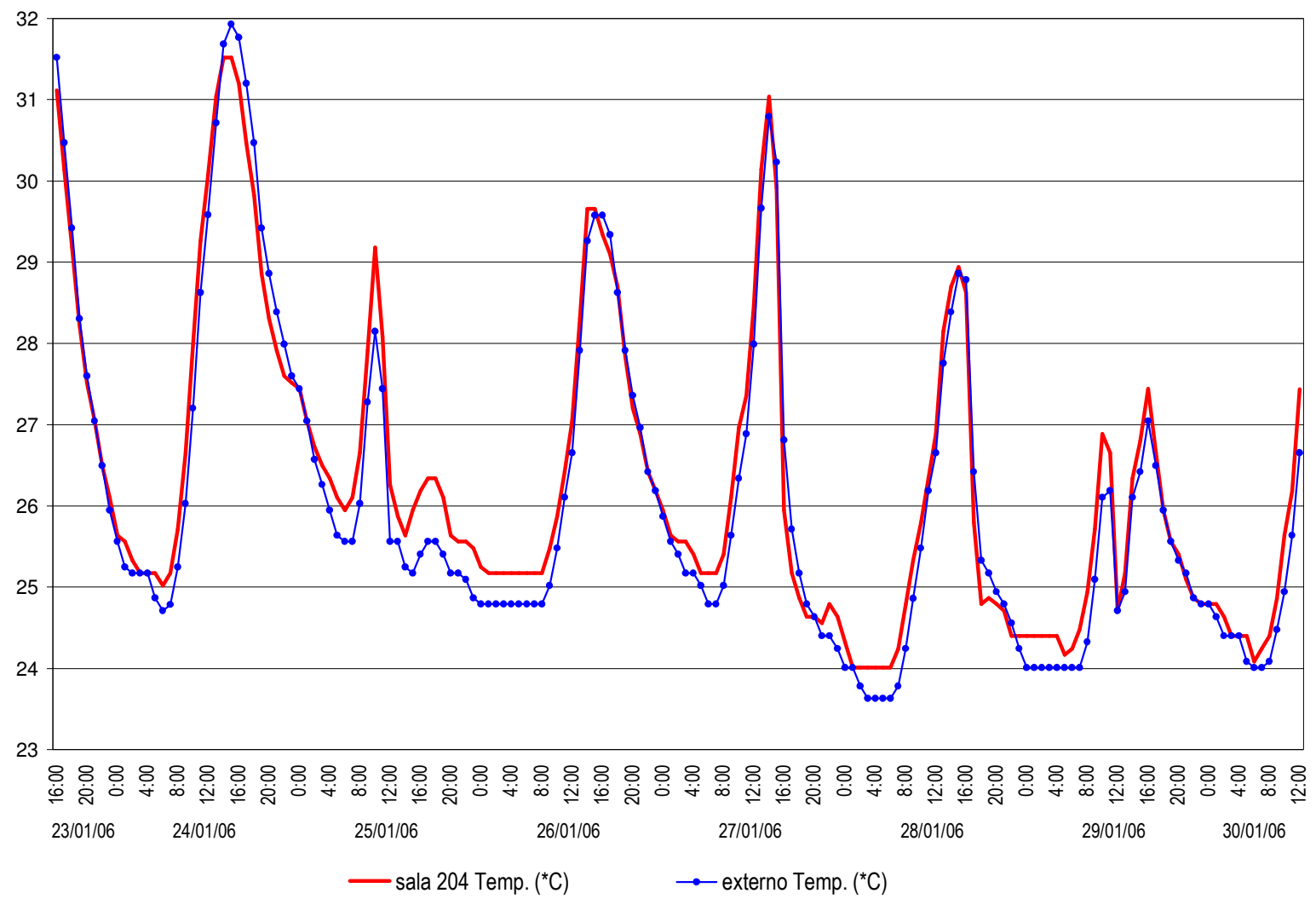

Gráfico 8.3: Temperatura do $\operatorname{ar}\left({ }^{\circ} \mathrm{C}\right)$ - interno (sala 204) x externo

O comportamento apresentado pela sala 204 foi semelhante à sala 207, com a oscilação de temperatura interna acompanhando a oscilação externa, o que revela baixo amortecimento e atraso térmico praticamente inexistente (gráfico 8.3). Os valores de umidade encontrados para este ambiente também foram semelhantes aos dados obtidos para a sala 207.

As medições realizadas na caixa de escadas do bloco de administração, que se separa da área externa por uma parede de elementos vazados em concreto, apresentaram resultados semelhantes aos obtidos no ponto externo, tanto de temperatura (gráfico 8.4) como de umidade. Este ponto foi escolhido pois pode auxiliar na análise do desempenho térmico de áreas externas que possuem a cobertura padrão da Universidade, feita em estrutura metálica e telha de fibrocimento. 


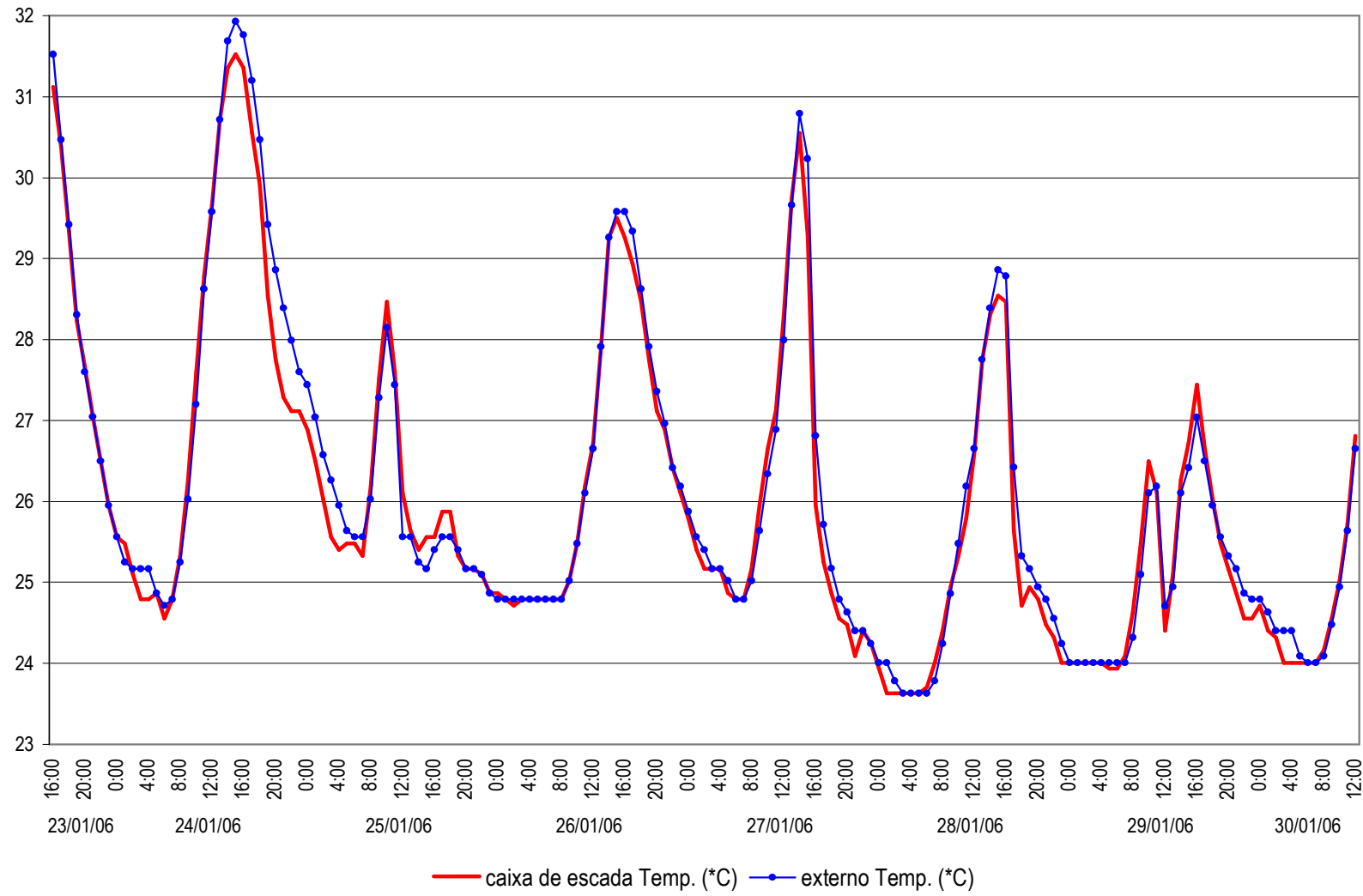

Gráfico 8.4: Temperatura do ar $\left({ }^{\circ} \mathrm{C}\right)$ - caixa de escadas x externo

\subsubsection{Dados obtidos para velocidade do ar}

As medições de velocidade do ar foram realizadas nas duas salas de aula escolhidas, 207 e 204, em quatro diferentes pontos do ambiente interno e em um ponto externo, para que pudesse haver comparações quantitativas. As duas salas são idênticas em tamanho e forma, variando apenas o posicionamento em planta. As medições foram feitas a uma altura de um metro em relação ao piso, que é a altura da zona ocupada pelos estudantes sentados nas carteiras. Todas as medições foram realizadas fora dos períodos de aulas, nas salas vazias, devido à dimensão do equipamento, que atrapalharia os usuários.

O fechamento das aberturas localizadas no forro para instalação do equipamento de refrigeração artificial prejudicou a pesquisa no edifício de acordo com o projeto original, já que não funciona mais a ventilação por efeito chaminé; porém pode-se verificar como ocorre o movimento de ar por ventilação cruzada. Outro fator prejudicial para as medições foi a impossibilidade de abertura de todas as esquadrias, devido ao sistema de abertura de algumas delas encontrar-se quebrado (como já foi especificado nos itens 8.2.1.1 e 8.2.1.2). 
Os resultados obtidos apresentam-se nos gráficos e figuras a seguir:

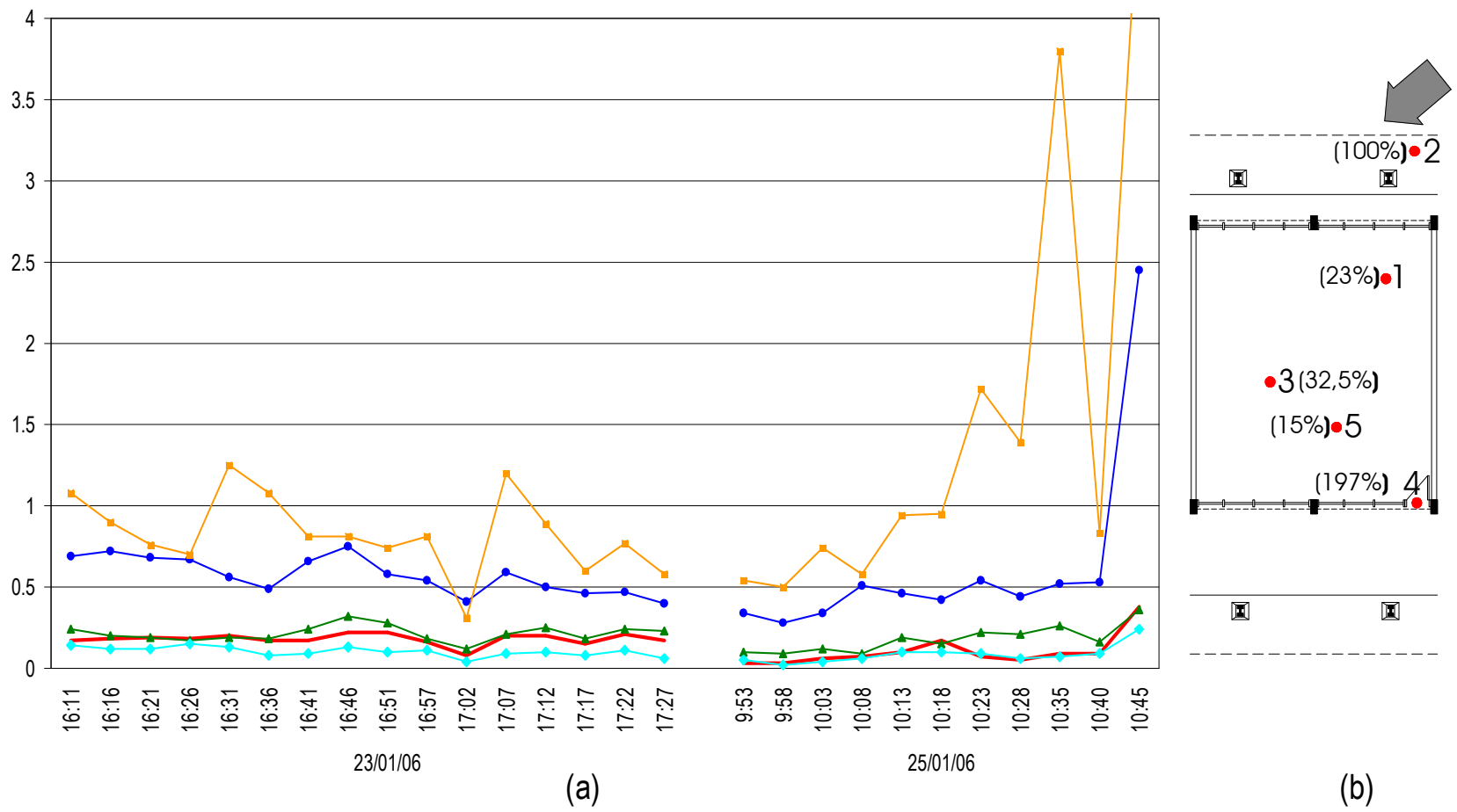

$\longrightarrow$ Veloc. pto $1(\mathrm{~m} / \mathrm{s}) \rightarrow$ Veloc. pto $2(\mathrm{~m} / \mathrm{s})$ - externo $\mathrm{N} \rightarrow$ Veloc. pto $3(\mathrm{~m} / \mathrm{s}) \longrightarrow$ Veloc. pto $4(\mathrm{~m} / \mathrm{s}) \rightarrow$ Veloc. pto $5(\mathrm{~m} / \mathrm{s})$

Gráfico 8.5: (a) Sala 207 - velocidade do ar (m/s); (b) Posicionamento 1

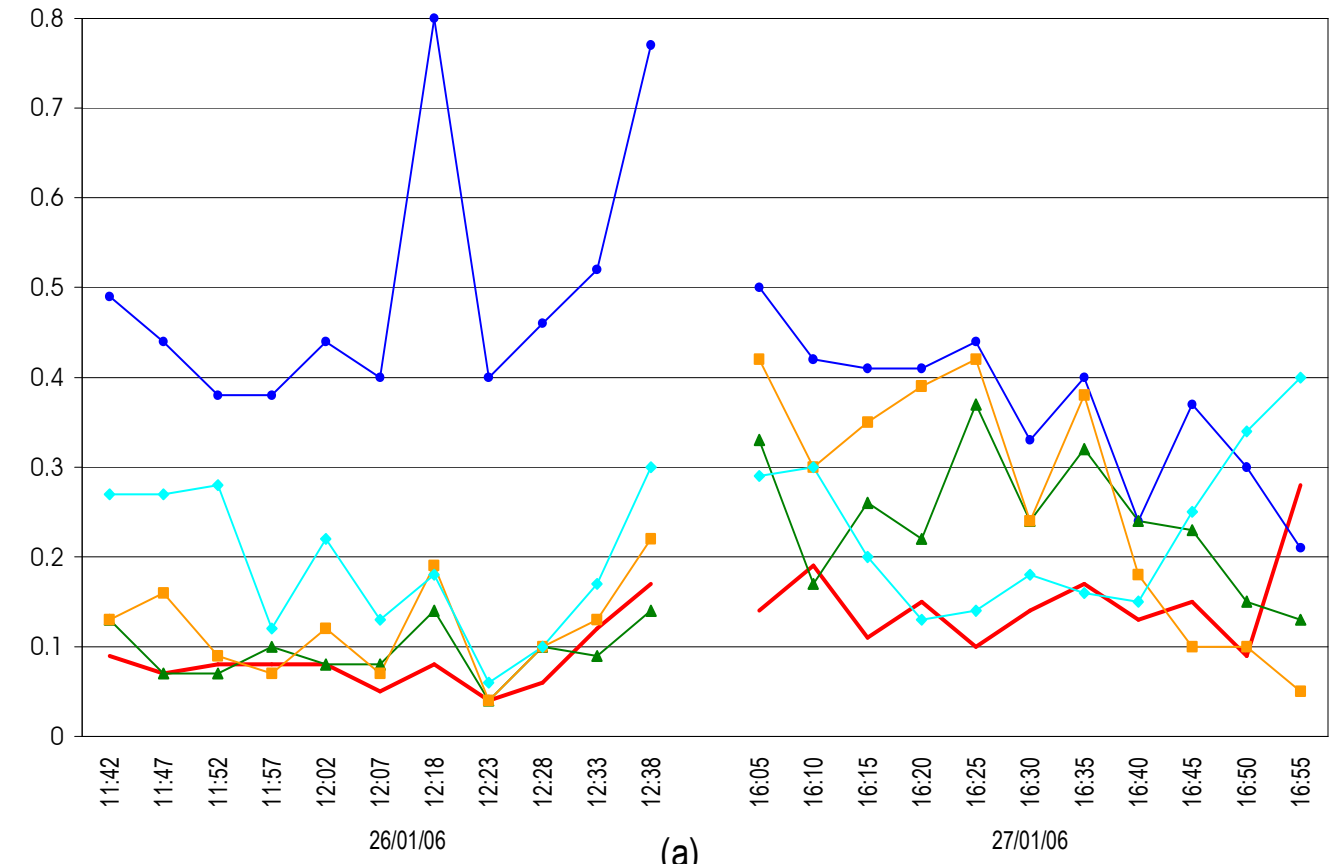

(a)

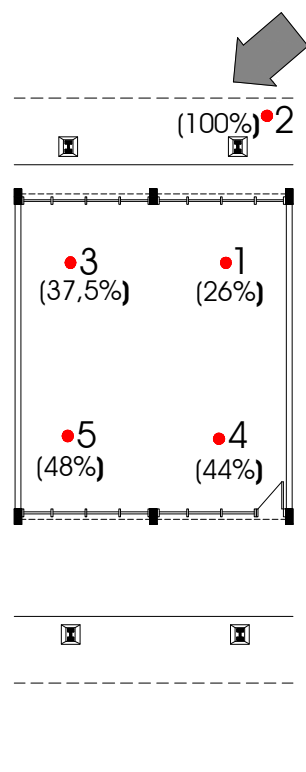

(b)

$\longrightarrow$ Veloc. pto $1(\mathrm{~m} / \mathrm{s}) \rightarrow$ Veloc. pto $2(\mathrm{~m} / \mathrm{s})$ - externo $\mathrm{N} \rightarrow$ Veloc. pto $3(\mathrm{~m} / \mathrm{s}) \rightarrow$ Veloc. pto $4(\mathrm{~m} / \mathrm{s}) \rightarrow$ Veloc. pto $5(\mathrm{~m} / \mathrm{s})$ Gráfico 8.6: (a) Sala 207 - velocidade do ar (m/s); (b) Posicionamento 2 
As figuras ao lado dos gráficos apresentam o valor médio da velocidade do ar no interior em relação ao vento externo disponivel (em porcentagem), o que dá uma expressão quantitativa da eficiência da ventilação e é útil para avaliar o potencial do uso do vento no ambiente interno.

Ao observar os gráficos, pode-se notar como os resultados de ventilação por meios naturais variam a todo momento, devido à variação na velocidade e direção do vento. Incluem períodos de maior calmaria e períodos onde o fluxo do ar foi mais intenso, geralmente antecedendo chuvas. Na sala de aula 207, as medições foram realizadas em quatro dias: o dia 23/01 (gráfico 8.5), quando o céu estava parcialmente nublado, sem chuva; o dia 25/01 (gráfico 8.5), ensolarado no início das medições, mas com chuva forte a partir das 10h40min, o que aumentou a velocidade do vento; o dia 26/01 (gráfico 8.6), de céu nublado, sem chuva; e o dia 27/01 (gráfico 8.6), com chuva fraca durante as medições.

A média da velocidade do ar externo, para as medições efetuadas, ficou em $0,52 \mathrm{~m} / \mathrm{s}$, um valor extremamente baixo, considerando-se que sempre há uma perda de velocidade do ar quando penetra no ambiente interno. Isto significa que o vento disponível no exterior já não é adequado para que haja uma boa ventilação natural do edifício.

No posicionamento 1 , observa-se um fluxo de ar mais forte no ponto 4, localizado na entrada da sala (média de $1,18 \mathrm{~m} / \mathrm{s}$ ), superando inclusive a velocidade do ar externa, o que se deve à canalização do vento ocorrida no corredor de circulação. Porém, este vento não chega a penetrar no ambiente, já que no ponto 5 , situado próximo à entrada, a velocidade do ar foi a mais baixa das medições, ficando em torno de apenas $0,09 \mathrm{~m} / \mathrm{s}, 15 \%$ da velocidade externa. 0 ponto 1 , situado próximo à abertura de entrada, também apresentou velocidades baixas (média de $0,14 \mathrm{~m} / \mathrm{s}$ ). Este ponto sofre influência da vedação Leste, que divide uma sala da outra, e pode formar uma zona de sombra de vento no local, já que a incidência dos ventos dominantes é oblíqua às aberturas de entrada do ar. 0 ponto 3 , situado próximo ao centro da sala, foi o que apresentou as maiores velocidades internas, em torno de $0,2 \mathrm{~m} / \mathrm{s}, 0$ que, entretanto, ainda são valores muito baixos. O gráfico 8.5 mostra claramente 0 baixo aproveitamento do vento externo disponível, pois as linhas que representam os pontos internos (exceto o ponto 4) encontram-se constantemente bastante abaixo da linha do ponto externo (ponto 2).

No posicionamento 2, pode-se ter uma idéia da distribuição geral do fluxo de ar no interior da sala de aula. Os pontos 1 e 3, localizados próximos à fachada Norte, onde estão as aberturas de entrada do ar, possuem velocidades médias de $0,12 \mathrm{~m} / \mathrm{s}$ e $0,17 \mathrm{~m} / \mathrm{s}$, respectivamente. Apresentam um menor índice de aproveitamento do vento externo do que os pontos 4 e 5 , situados próximos às aberturas de saída do ar, fachada Sul. Estes pontos possuem velocidades em torno de $0,20 \mathrm{~m} / \mathrm{s}$ a $0,25 \mathrm{~m} / \mathrm{s}$, chegando a picos de até $0,42 \mathrm{~m} / \mathrm{s}$ no ponto 4 . Pode-se notar que 0 ar atinge velocidades um pouco mais elevadas ao atingir as aberturas de saída, que são ligeiramente menores do que as de entrada. 
A seguir, são apresentados os resultados para a sala 204:

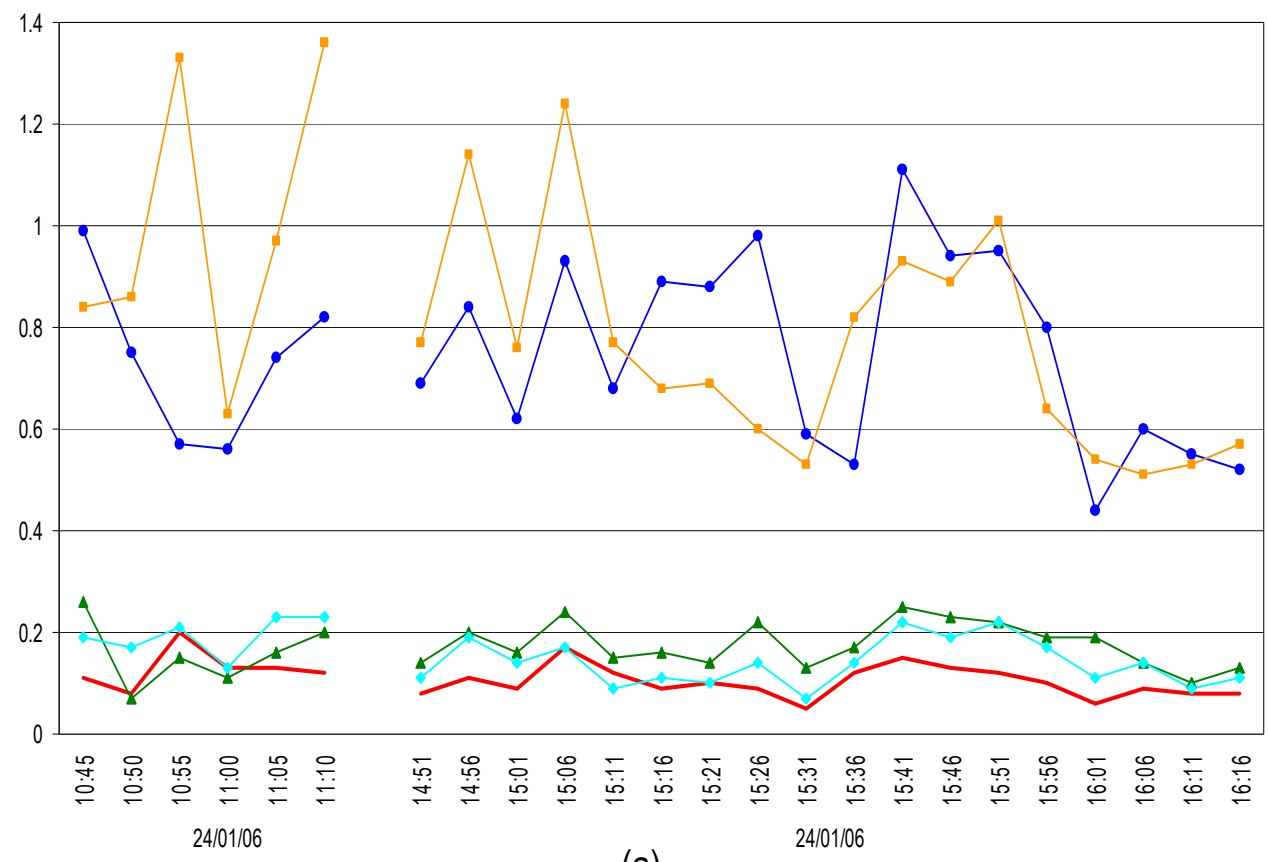

(a)

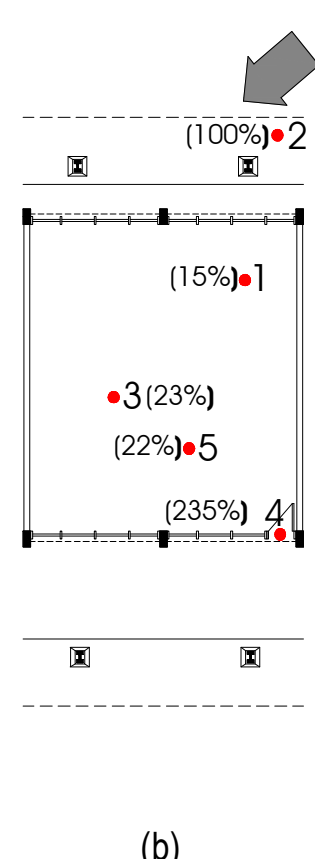

$\longrightarrow$ Veloc. pto $1(\mathrm{~m} / \mathrm{s}) \longrightarrow$ Veloc. pto $2(\mathrm{~m} / \mathrm{s})$ - externo $N \longrightarrow$ Veloc. pto $3(\mathrm{~m} / \mathrm{s}) \longrightarrow$ Veloc. pto $4(\mathrm{~m} / \mathrm{s}) \longrightarrow$ Veloc. pto $5(\mathrm{~m} / \mathrm{s})$

Gráfico 8.7: (a) Sala 204 - velocidade do ar (m/s); (b) Posicionamento 1

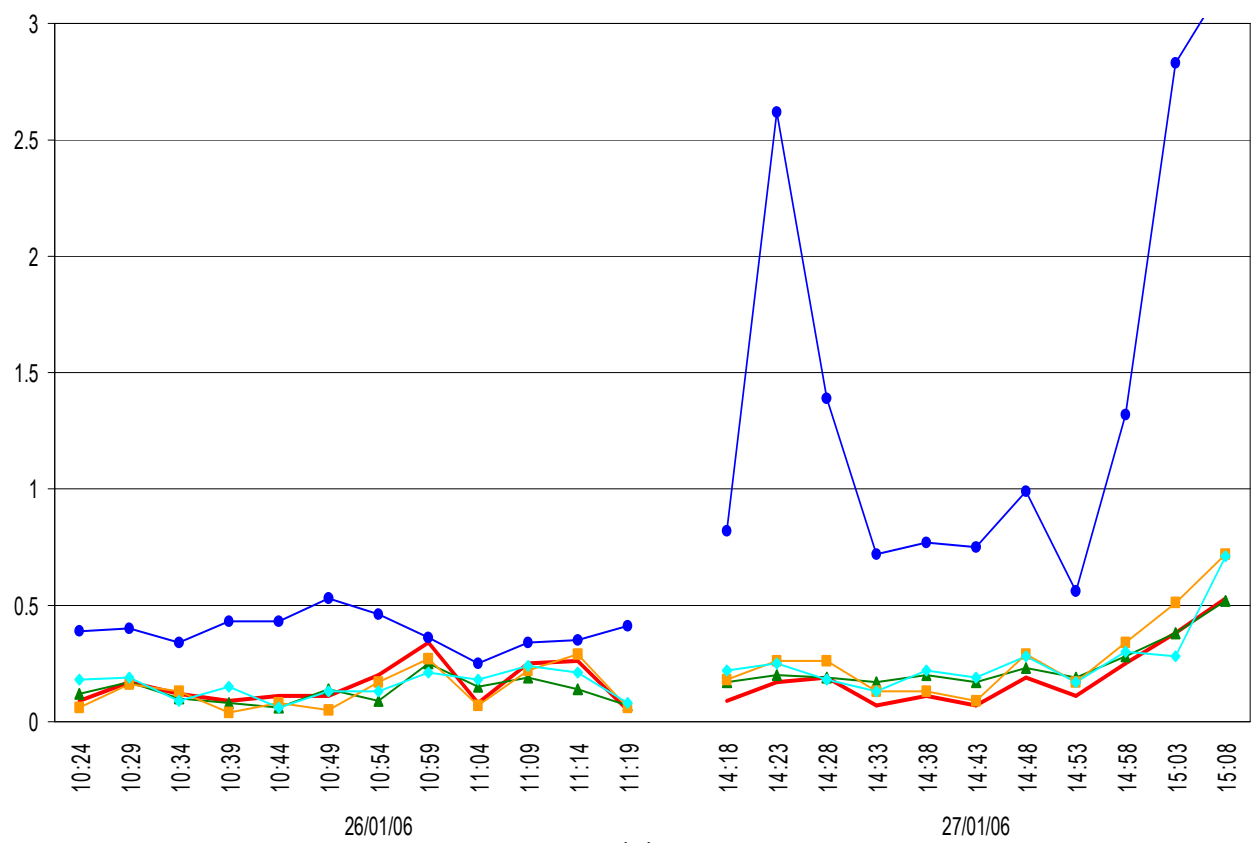

(a)

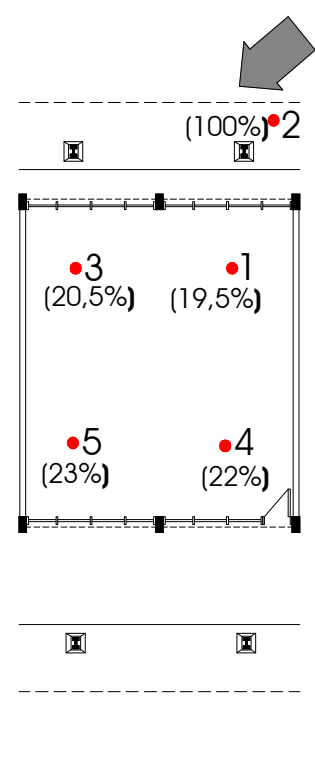

(b)

$\longrightarrow$ Veloc. pto $1(\mathrm{~m} / \mathrm{s}) \longrightarrow$ Veloc. pto $2(\mathrm{~m} / \mathrm{s})$ - externo $\mathrm{N} \rightarrow$ Veloc. pto $3(\mathrm{~m} / \mathrm{s}) \longrightarrow$ Veloc. pto $4(\mathrm{~m} / \mathrm{s}) \longrightarrow$ Veloc. pto $5(\mathrm{~m} / \mathrm{s})$

Gráfico 8.8: (a) Sala 204 - velocidade do ar (m/s); (b) Posicionamento 2 
Na sala 204, foram realizadas medições em diferentes períodos de três dias: no dia 24/01 (gráfico 8.7), que estava ensolarado; dia 26/01 (gráfico 8.8), de céu nublado, sem chuva; e dia 27/01 (gráfico 8.8), de céu aberto, que foi se fechando no decorrer das medições e teve chuva forte a partir de 15hs. A média da velocidade do ar externo obtida em todas as medições, para a sala 204 , foi de $0,83 \mathrm{~m} / \mathrm{s}$.

No posicionamento 1, os pontos 1, 3 e 5, localizados no ambiente interno, apresentaram velocidades do ar em torno de $0,1 \mathrm{~m} / \mathrm{s}$ a $0,2 \mathrm{~m} / \mathrm{s}$. Nota-se que os pontos internos, na maior parte do tempo, possuem velocidades consideravelmente abaixo da velocidade externa, demonstrando um baixo aproveitamento do vento externo disponível. Apenas o ponto 4 possui velocidade mais elevada, em torno de $0,9 \mathrm{~m} / \mathrm{s}$, devido à posição próxima à porta, como já foi dito acima. 0 posicionamento 2 mostrou um baixo aproveitamento do vento para todos os pontos, por volta de $20 \%$, ficando abaixo do obtido pela sala 207.

Para as duas salas de aula, pode-se verificar que a velocidade do ar interna raramente ultrapassa 0 valor de 0,3m/s, ficando, em média, entre 0,1 e 0,2m/s. Apenas em dias de chuva, em que o vento externo é mais forte, a velocidade interna também se eleva um pouco. Porém, o índice de aproveitamento do vento livre disponível é sempre baixo, não chegando a $50 \%$.

\subsection{ANÁLISE DOS RESULTADOS}

Através do cruzamento dos dados obtidos nas análises qualitativa e quantitativa e das recomendações dadas por Mahoney e pela ASHRAE, pode-se agora realizar uma análise de desempenho térmico e, mais detalhadamente, de ventilação natural do edifício da Universidade.

\subsubsection{Análise de desempenho térmico: temperatura e umidade}

O intervalo de temperatura interna recomendado pela ASHRAE Standard 55-2004, para os meses de janeiro e fevereiro, é de $22,3^{\circ} \mathrm{C}$ a $29,3^{\circ} \mathrm{C}$, para $80 \%$ de aceitabilidade dos usuários de um espaço. Através destes valores de referência, pode-se analisar se os dados de temperatura interna obtidos pelas medições no bloco de salas de aula satisfazem os parâmetros de conforto térmico estabelecidos pela ASHRAE.

Os dados obtidos nas medições da sala 207 apontam valores de temperatura mínima entre $24^{\circ} \mathrm{C} \mathrm{e}$ $26^{\circ} \mathrm{C}$, sendo que a mínima registrada durante a semana foi de $24,01^{\circ} \mathrm{C}$, nos dias 28 e $29 / 01$. Estes 
valores estão dentro dos limites da norma, e são considerados confortáveis, como já era esperado. Já os picos de temperatura máxima chegam a ser superiores ao valor de $29,3^{\circ} \mathrm{C}$, demarcando períodos em que o ambiente está fora da zona de conforto. Os intervalos de tempo em que este valor é ultrapassado são:

Tabela 8.4: Períodos em que os valores de temperatura obtidos para a sala 207 estão fora da zona de conforto

\begin{tabular}{|c|c|}
\hline Dias & Horários \\
\hline $23 / 01$ & 16h às 17h45min \\
\hline $24 / 01$ & 11h15min às 18h30min \\
\hline $26 / 01$ & 14h às 16h30min \\
\hline $27 / 01$ & 12h30min às 15h15min \\
\hline
\end{tabular}

O resultado indica que esta oscilação de temperatura interna, acompanhando a oscilação externa, pode ser prejudicial nos períodos mais quentes do dia - durante a tarde - pois quando a temperatura externa ultrapassa o limite de conforto a interna também ultrapassa, podendo gerar desconforto aos usuários. No período de medições efetuadas, estes intervalos de desconforto ocuparam geralmente parte da tarde, e houve dias em que a temperatura interna não chegou a sair da zona de conforto. Porém, vale ressaltar que as medições foram realizadas no período menos quente do ano para a região, e que durante o período mais quente (meses de julho a outubro), onde as condições são mais críticas, o desconforto térmico dos ambientes pode ser pior, e por períodos mais longos.

A quase inexistência de amortecimento e atraso térmico do edifício revela a baixa inércia térmica da construção, solução recomendada para o clima quente e úmido, já que as oscilações de temperatura externa são baixas. 0 atraso térmico, que nas medições foi praticamente inexistente, está dentro dos limites recomendados por Mahoney, que é de no máximo três horas. Porém, seria indicado que houvesse maior isolamento térmico e/ou reflexão da radiação solar pelas superfícies externas, com a devida atenção para utilização de materiais leves, que não armazenem calor, para não prejudicar o desempenho térmico do ambiente no período noturno.

Para analisar o desempenho térmico dos materiais utilizados na construção do bloco de salas de aula foram utilizadas como parâmetro as diretrizes traçadas por Mahoney. Para as paredes, Mahoney indica a utilização de materiais leves (de baixa inércia térmica) e superfícies de cores claras para refletir a radiação solar. Através do cálculo da transmitância térmica da parede e do fator de calor solar da superfície, pode-se verificar se os materiais utilizados (especificados na tabela 8.1) estão dentro dos limites especificados por Mahoney. 
A transmitância da parede de tijolos com furos e revestimento externo de pastilha cerâmica (espessura total $=20 \mathrm{~cm}$ ) é de $2,14 \mathrm{~W} / \mathrm{m}^{2} \mathrm{C}$, o que está dentro do valor especificado por Mahoney, que é de, no máximo, $2,8 \mathrm{~W} / \mathrm{m}^{2}{ }^{\circ} \mathrm{C}$. A cor da pastilha cerâmica utilizada é bege, que possui absortância de 0,3 e fator de calor solar de 2,6\%, também de acordo com o que Mahoney indica, que é de até $4 \%$.

Para a cobertura, Mahoney indica o uso de materiais leves, coberturas termicamente isoladas, e que reflitam a radiação do sol. Na Universidade, o sistema utilizado é uma cobertura principal de telha de fibrocimento com estrutura metálica, e os ambientes fechados possuem laje de concreto. $O$ valor da transmitância térmica para uma cobertura de telha de fibrocimento com laje de concreto de $12 \mathrm{~cm}$ de espessura, situação que se aproxima ao encontrado na Universidade, é de $1,93 \mathrm{~W} / \mathrm{m}^{2}{ }^{\circ} \mathrm{C}$, valor acima do recomendado por Mahoney, que é de no máximo $1,1 \mathrm{~W} / \mathrm{m}^{2}{ }^{\circ} \mathrm{C}$.

Como a telha de fibrocimento encontra-se enegrecida, o valor da absortância de radiação solar adotado para o cálculo do fator de calor solar da superfície foi de 0,65 . O resultado ficou em $5 \%$, valor também acima do recomendado por Mahoney, que é de até 4\%. A cobertura precisa de uma superfície externa mais refletora, por exemplo, uma pintura na cor branca, o que reduziria o fator solar para 2,3\%, aumentando a reflexão da radiação solar e contribuindo para a melhoria do desempenho térmico do ambiente interno.

Em vista disso, quanto aos materiais utilizados na construção, as vedações laterais apresentam desempenho térmico adequado ao clima, mas a cobertura está fora dos limites recomendados. Para reduzir a transmitância e melhorar o desempenho térmico da cobertura deveria ter sido utilizado, juntamente com a laje, algum material isolante térmico ou refletor da radiação solar, como lã de vidro ou alumínio polido. Um aumento da resistência térmica da cobertura poderia contribuir para aumentar o amortecimento do ambiente interno, evitando ou reduzindo os períodos em que a temperatura atinge valores superiores ao recomendado pela ASHRAE.

Segundo dados obtidos na ABNT NBR 15220 (2003), uma cobertura de telha de fibrocimento com laje de concreto de $20 \mathrm{~cm}$ possui transmitância térmica de $1,99 \mathrm{~W} /\left(\mathrm{m}^{2} . \mathrm{K}\right)$; já a mesma cobertura acrescida de uma lâmina de alumínio polido, este valor cai para 1,06 W/(m².K). Isto mostra a grande contribuição proporcionada pelo material refletor, que dificulta a penetração da radiação solar por transmitância térmica através do material.

A pintura da telha, citada acima, também é de grande importância. A utilização de cores claras na cobertura auxilia na redução da absorção da radiação incidente, contribuindo para o resfriamento do edifício internamente. Como se pode observar, a pintura da cobertura na cor branca é uma solução simples e que proporciona uma mudança significativa no desempenho térmico, sendo portanto 
altamente recomendada. Exige, porém, manutenção constante.

As medições realizadas na caixa de escadas (gráfico 8.4) mostram a baixa capacidade térmica da cobertura em estrutura metálica e telha de fibrocimento, pois os valores obtidos de temperatura acompanham a temperatura externa. Quanto aos ambientes fechados, outro fator que contribui para o desempenho apresentado é o grande número de aberturas voltadas para a área externa, que visam proporcionar ventilação natural. Os materiais utilizados na parede apresentam inércia térmica significativa, porém as aberturas fazem com que o ambiente fechado tenha um contato grande com 0 exterior.

$\mathrm{O}$ monitoramento indicou uma média da temperatura interna superior à média externa $-26,3^{\circ} \mathrm{C}$ e $26,1^{\circ} \mathrm{C}$, respectivamente. As trocas de ar com 0 ambiente externo, proporcionadas pelas aberturas para ventilação natural, fazem com que a temperatura interna tenha forte relação com a temperatura externa. Porém ganhos térmicos internos, devido à presença de usuários e à iluminação artificial, e ganhos térmicos solares fazem com que haja este pequeno acréscimo.

Segundo Rivero (1988), é importante conhecer as oscilações de temperatura e a hora em que se registra seus máximos valores para poder analisar mais precisamente os sistemas de ventilação. Por isso, com o auxílio desta primeira análise, serão verificados a seguir os resultados obtidos pelas medições de velocidade do ar realizadas.

\subsubsection{Análise de ventilação natural}

Alguns dados básicos da sala de aula estudada, essenciais para análise da ventilação natural, são reapresentados aqui: o ambiente possui $8 \mathrm{~m}$ de comprimento por $7 \mathrm{~m}$ de largura, sendo que as aberturas de ventilação estão dispostas nas paredes de menor dimensão $(7 \mathrm{~m})$. As aberturas de entrada do ar estão na fachada Norte, onde o vento incide obliquamente, e ocupam $74 \%$ da área total da parede; as aberturas de saída do ar estão na fachada Sul e ocupam 53,3\% da área da parede, valores que se encontram dentro da faixa especificada por Mahoney. A área de saída do ar é 21,6\% menor do que a área de entrada - a saída possui $13,8 \mathrm{~m}^{2}$ de área e a entrada possui $17,6 \mathrm{~m}^{2}$ diferença que ocorre devido ao tamanho do peitoril da esquadria, que na saída é mais alto, proporcionando um fluxo de ar ascendente.

Os resultados obtidos pelas medições em diversos pontos da sala de aula 207 permitem realizar o traçado esquemático de como se dá o escoamento e a distribuição do ar internamente, que se 
apresenta na figura seguinte:

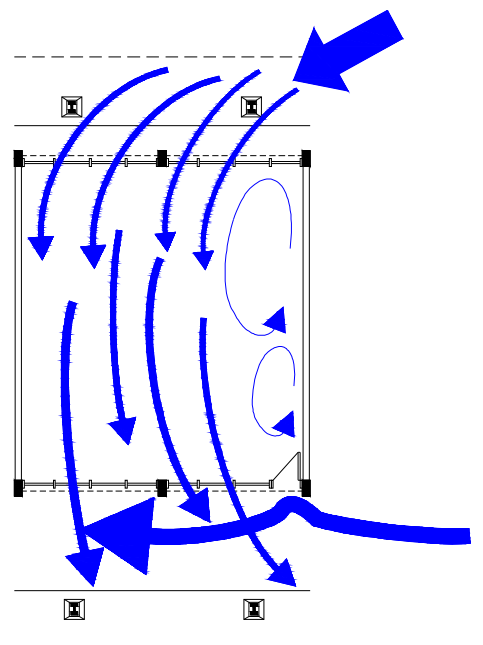

Figura 8.54: Esquema do fluxo de ar interno na sala de aula 207

Sabe-se que a abertura menor, seja de entrada ou de saída, é que determina a velocidade média do ar internamente, e que entradas e saídas de tamanhos próximos resultam em uma ventilação mais distribuída. Neste caso, como as esquadrias ocupam toda a extensão da fachada e o tamanho da abertura de saída não é consideravelmente menor do que a de entrada, pode-se concluir que o fluxo de ar é bem distribuído internamente. Isto é comprovado pela análise quantitativa, que obteve valores de velocidade do ar próximos para os diversos pontos de medição no ambiente interno.

Porém, o nível de aproveitamento do vento externo disponível está abaixo do esperado, de acordo com os estudos realizados por Givoni (1976). Nestes estudos, Givoni mostra que, para aberturas em paredes opostas e incidência oblíqua do vento, considerando a largura dos vãos de entrada e saída do ar como $3 / 3$ da parede, os valores obtidos de velocidade interna seriam de, em média, $65 \%$ da velocidade externa. Como na sala de aula analisada as aberturas de entrada e saída do ar ocupam toda a extensão da parede, seria esperado um aproveitamento médio do vento externo disponível em torno deste valor. Contudo, para a sala 207 o aproveitamento médio foi de 39\% (figura 8.55) e, para a sala 204 , foi de $21 \%$ (figura 8.56 ), valores bastante abaixo do esperado, principalmente para a sala 204, cuja localização em planta é no centro do bloco de salas de aula. 


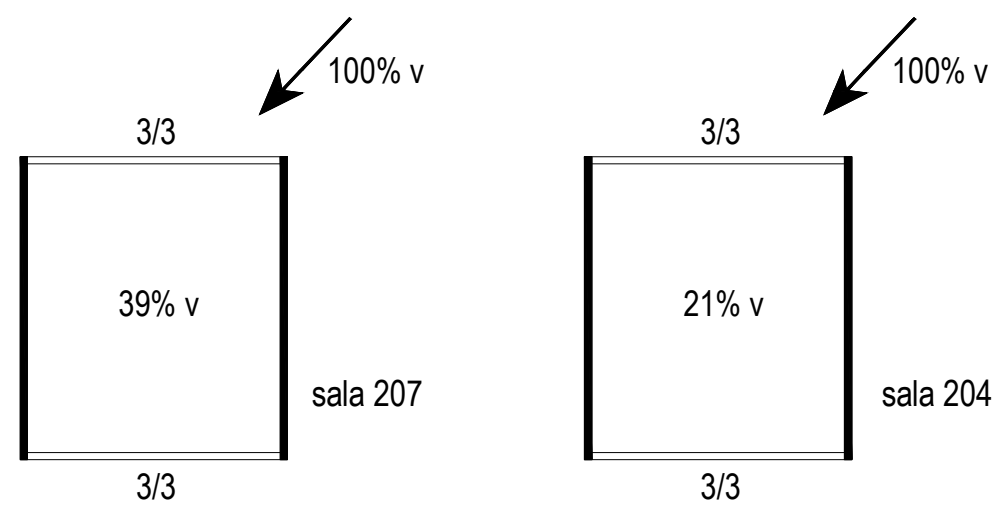

Figuras 8.55 e 8.56: Aproveitamento médio do vento no espaço interno, salas 207 e 204

Este fator torna-se agravante quando são analisadas as velocidades de ar obtidas, pois o vento externo disponível já é fraco e insuficiente para que haja uma ventilação natural adequada. A média de vento externo obtida nas medições da sala 207 foi de 0,52m/s, e a média interna ficou entre 0,10 e 0,25m/s. Segundo Olgyay (1998) e Evans (1957 apud FREIXANET; VIQUEIRA, 2004), até 0,25m/s o movimento de ar é imperceptível ao homem, exceto a baixas temperaturas, o que leva a concluir que praticamente não ocorre ventilação natural dentro da sala de aula.

$\mathrm{Na}$ sala 204, apesar da média de vento exterior ter sido mais elevada, $0,83 \mathrm{~m} / \mathrm{s}$, a velocidade interna ficou entre 0,13 e $0,28 \mathrm{~m} / \mathrm{s}$, valores próximos aos obtidos na sala 207. Nos dois casos, como o vento livre disponível já é pouco, o baixo aproveitamento interno compromete ainda mais a ventilação cruzada.

Ainda segundo Evans (1957 apud FREIXANET; VIQUEIRA, 2004), o vento à velocidade de $0,25 \mathrm{~m} / \mathrm{s}$ provoca um efeito de esfriamento de $0,7^{\circ} \mathrm{C}$ sobre o homem. $O$ mesmo valor é encontrado no gráfico de queda na temperatura equivalente, elaborado por Borel (1967), para uma temperatura do ar de $25^{\circ} \mathrm{C}$ (a temperatura média do ar durante a semana de medições foi de $\left.26,1^{\circ} \mathrm{C}\right)$. Sabendo que a temperatura máxima de conforto para a região, na época analisada, é de $29,3^{\circ} \mathrm{C}$, a ventilação encontrada permitiria que a temperatura interna atingisse um valor máximo de $30^{\circ} \mathrm{C}$, para que 0 ambiente pudesse continuar sendo considerado confortável. Entretanto, foram atingidos valores superiores a este, no período da tarde em alguns dias de monitoramento, sendo que o pico máximo para as duas salas foi de $31,93^{\circ} \mathrm{C}$, ocorrido no dia $24 / 01$ às $14 \mathrm{hs}$. Neste dia, o ideal seria uma ventilação em torno de $0,75 \mathrm{~m} / \mathrm{s}$, segundo Borel (1967), para amenizar o efeito da temperatura elevada e atingir uma temperatura equivalente dentro da zona de conforto.

Pode-se concluir, portanto, que a ventilação cruzada do bloco de salas de aula da Universidade não funciona apropriadamente. Um dos motivos principais é a baixa velocidade do vento livre disponível no 
exterior, o que se agrava pela presença de mata nativa fechada no entorno e pela presença de jardins muito densos entre as edificações, que atrapalham a circulação de ar. As esquadrias das salas de aula, apesar de serem amplas e possuírem sistema de funcionamento que possibilita máxima abertura, não se aproveitam da melhor forma possível dos ventos em algumas ocasiões. Uma das prováveis causas é devido ao posicionamento relativo às aberturas de entrada, em função das características dinâmicas de incidência do vento, fator que reduz sua área efetiva. Estas aberturas estão posicionadas na direção Norte, sendo que a direção de incidência dos ventos varia de Norte a Leste. Quando o vento está mais próximo da direção Leste, a captação para o ambiente interno é muito baixa. Um fator prejudicial para a análise foi o fato de algumas esquadrias estarem com o sistema de abertura quebrado, conseqüência da falta de manutenção adequada do edifício.

O efeito chaminé, estratégia de ventilação natural presente no projeto original e hoje bloqueada, poderia ser uma solução para incrementar a ventilação no interior dos ambientes. Porém, sabe-se que um dos fatores primordiais para a ocorrência de ventilação por diferença de temperatura é a diferença de altura entre as aberturas de entrada e saída do ar, e neste caso este valor é de apenas 2,10m. De modo geral, esta altura não permite que haja um gradiente de temperatura razoável, indicando que, provavelmente, esta estratégia não contribuiria muito para aumentar o fluxo de ar interno.

\subsubsection{Considerações finais}

O projeto da Universidade mostra claramente a preocupação de Severiano Porto em adotar estratégias condizentes ao clima local. Porto procura implantar os edifícios de acordo com a trajetória solar e os ventos dominantes locais, protege as aberturas contra a incidência direta da radiação solar e contra as chuvas, proporciona espaçamento suficiente entre as edificações para permitir a livre circulação do ar, utiliza ventilação cruzada aliada ao efeito chaminé visando a climatização natural dos ambientes internos. A obra se destaca pela preocupação constante do arquiteto em aplicar diversos conceitos bioclimáticos, o que não se observa na grande maioria das construções que se encontra na cidade de Manaus.

Uma crítica importante a ser destacada é a falta de iluminação natural adequada nos ambientes internos. A luz natural poderia ser aproveitada nas salas de aula durante todo o dia, mas o que se vê é o uso constante de iluminação artificial, o que pode gerar maior desconforto, pois a luz artificial é mais uma fonte geradora de calor para o ambiente interno, além de provocar um consumo desnecessário de energia. Uma recomendação básica e extremamente difundida para construções em regiões de clima 
quente e úmido é o uso moderado da luz natural, principalmente devido ao calor trazido pela radiação solar. Mas o que realmente importa é obter uma boa iluminação interna e reter o calor para o lado de fora da edificação.

Quanto à ventilação natural, a análise mostra que as intenções do arquiteto foram adequadas, porém o resultado encontrado mostra uma ventilação insuficiente. Além do vento externo disponível ser fraco, o aproveitamento interno está abaixo do esperado. Sabe-se que a ventilação possui aspectos técnicos que exigem uma consultoria especializada para detalhar com maior precisão. Apesar de faltarem dados técnicos para maior detalhamento de algumas estratégias - principalmente, neste caso, com relação ao efeito chaminé - a preocupação e a presença de conceitos aplicados são claras.

Para a época do ano em que o edifício foi analisado, pode-se dizer que o desempenho mostrou-se adequado ao clima, pois na maior parte do tempo a temperatura obtida no monitoramento estava dentro da zona de conforto estabelecida pela ASHRAE. Uma questão que se coloca neste momento, no entanto, é qual o motivo que levou à realização de modificações para instalação de ar condicionado em todos os ambientes fechados, em um projeto que apresenta claras preocupações com obtenção de conforto térmico por vias passivas. Aqui entra um dado importante que deve ser levado em conta na análise da obra de Severiano Porto: a difusão indiscriminada e desnecessária do uso de sistemas de climatização artificial. A população se tornou, de certa forma, "viciada" em ar condicionado, e o utiliza frequentemente em situações onde é perfeitamente possivel a obtenção de conforto por condições naturais. Quem visita a cidade de Manaus nota claramente a dificuldade de encontrar ambientes que façam uso apenas da climatização natural, mesmo em dias em que o uso de ar condicionado é desnecessário.

Deve ser levado em consideração que o monitoramento foi realizado na época menos quente do ano, para a cidade de Manaus. Falta uma análise no período considerado crítico, entre os meses de julho e outubro, quando as temperaturas médias mensais atingem valores de aproximadamente $27,5^{\circ} \mathrm{C}$, e as máximas chegam a $36^{\circ} \mathrm{C}^{24}$. Entretanto, no período em que a pesquisa de campo foi realizada, meses de janeiro e fevereiro, a climatização artificial também é utilizada constantemente, enquanto sabe-se que, de acordo com os resultados encontrados, a edificação permite um bom nível de conforto por meios naturais.

24 Ver tabelas 3.3 e 3.4 do item 3.1 . 


\section{SEDE DA SUPERINTENDÊNCIA DA ZONA FRANCA DE MANAUS (SUFRAMA), 1973}

Construção com forte presença de concreto armado, a obra se destaca, neste contexto de análise, pela proposta apresentada para ventilação por efeito chaminé. 0 edifício é marcado por dois projetos distintos - ambos realizados por Severiano Porto - devido a um incêndio ocorrido na década de 1990, que destruiu toda sua área interna. A reconstrução foi um momento em que diversos problemas presentes no projeto original procuraram ser resolvidos. Para levantamento e detalhamento de dados relevantes da reforma foi essencial a etapa de pesquisa de campo, pois alguns dados não puderam ser obtidos na etapa de análise projetual. A análise qualitativa e descritiva, apresentada a seguir, foi complementada por estes dados; em continuação apresenta-se a análise quantitativa, com os dados resultantes do monitoramento; e a análise de resultados.

\subsection{ANÁLISE QUALITATIVA E DESCRITIVA}

A Suframa é a sede administrativa do órgão responsável pelo planejamento, implantação e administração da Zona Franca de Manaus, do distrito industrial e do distrito agropecuário. 0 projeto deste edifício foge das soluções regionais usualmente adotadas pelo arquiteto - que na época já era muito conhecido por seu trabalho com a madeira - a favor de proporcionar uma imagem de maior solidez e permanência ao órgão, através da forma arquitetônica da construção (PORTO, 2005; informação verbal). Não deixa, porém, de procurar adequar-se às características climáticas locais e inserir-se com harmonia no ambiente circundante, assim como procurou fazer no projeto para a Universidade.

Em projetos mais complexos, como o da Superintendência da Zona Franca de Manaus e o da Universidade, a preocupação com o regionalismo do vocabulário construtivo passa a um segundo plano. [...] Não variam, no entanto, as premissas ecológicas das concepções desses projetos. (CZAJOWSKI, 1976)

Porto trabalha diversos aspectos bioclimáticos nesta obra, sempre utilizando os elementos arquitetônicos a favor de uma maior adequabilidade às condições locais e buscando criar melhores condições de conforto ambiental. Segundo Minga (1990), esta obra é "Un ejemplo de obra con 
materiales contemporáneos que explota y responde a las condiciones climáticas de la región.", o que mostra a capacidade e disposição do arquiteto em trabalhar diferentes tipos de materiais.

Em agosto de 1994 parte do conjunto foi danificado por um incêndio, e a única parte do projeto original que restou intacta foi a cobertura de concreto. Porto, então, foi chamado para fazer o projeto de reforma e ampliação da sede, que foi concluído em 1995. O arquiteto aproveitou a oportunidade para procurar solucionar problemas de projeto que se apresentavam no edifício anterior, realizando diversas modificações, que se apresentarão a seguir.

\subsection{1 Área de inserção e implantação}

O terreno destinado à implantação da Suframa situa-se ao lado de uma rodovia que atravessa o município de Manaus. 0 entorno apresenta poucas construções e bastante vegetação nativa, ainda preservada. A área construída total é de $7.500 \mathrm{~m}^{2}$, sendo o edifício constituído por blocos distribuídos em uma trama de módulos de $15 \mathrm{~m} \times 15 \mathrm{~m}$, que podem ser acrescidos conforme a necessidade de expansão do conjunto. $O$ edifício é composto por dois blocos, um principal e um anexo, que possuem cota única de implantação e são interligados por uma passarela coberta. A área ao redor é destinada a estacionamento e garagem. A implantação se dá conforme a figura seguinte:

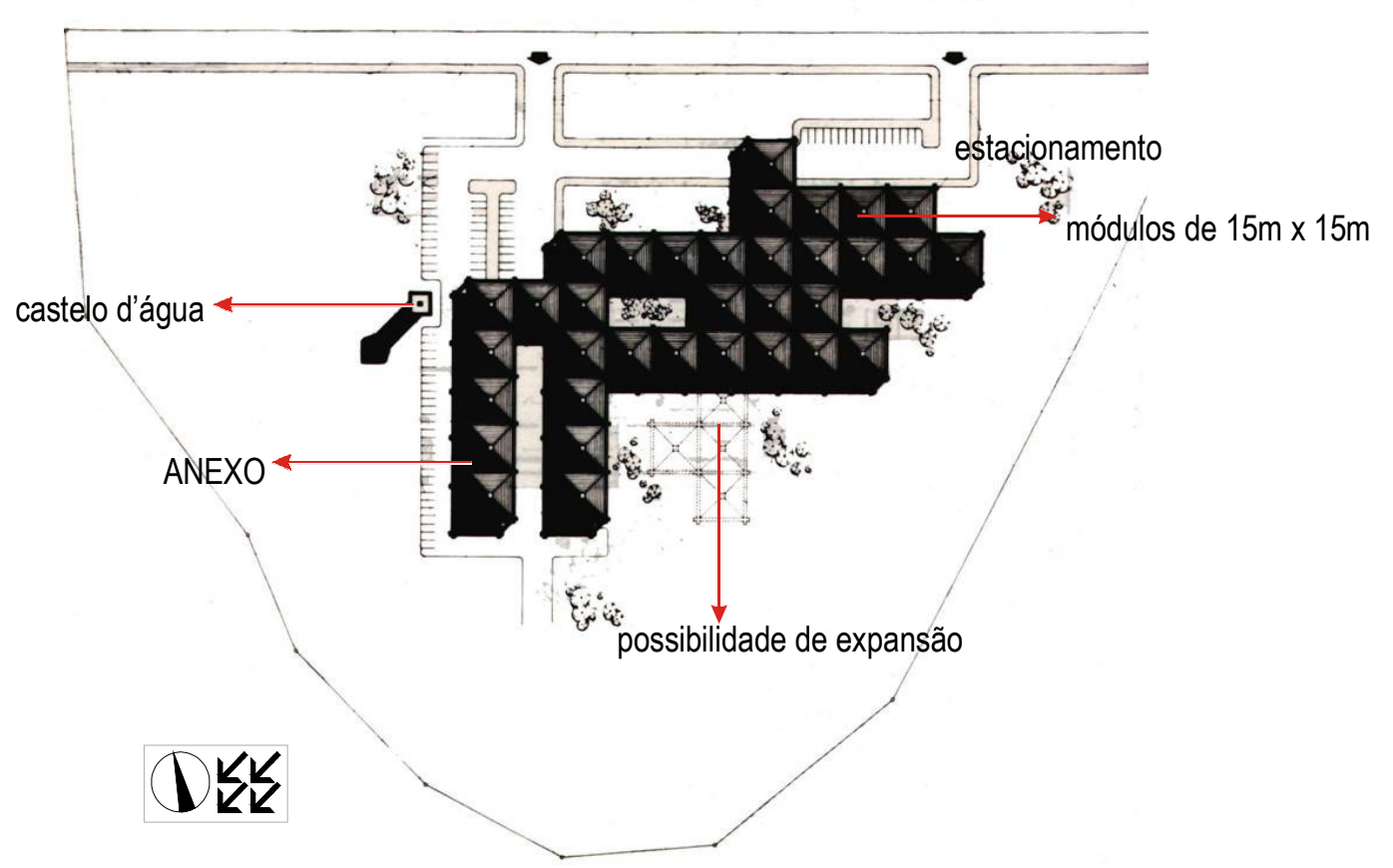

Figura 9.1: Planta de situação (PROJETO, 1982b) 


\subsubsection{0 edifício}

O conjunto arquitetônico é constituído pelo bloco de administração, museu, biblioteca e auditório, castelo d'água e área de estacionamento. Em anexo fica o "suframinha", que possui dois andares, onde funcionam o restaurante e alguns escritórios. A ligação entre os diversos ambientes fechados se dá por pátios e corredores cobertos, tudo organizado embaixo de uma cobertura única, em concreto, que é dividida em módulos e dá suporte estrutural ao conjunto. Dentro do prédio principal há um jardim interno, que ocupa o espaço de dois módulos.

No projeto de reforma, após o incêndio, os ambientes fechados sofreram diversas modificações em relação ao projeto original, assim como alguns espaços abertos de circulação e estar. A planta a seguir apresenta o projeto da Suframa após a reforma:

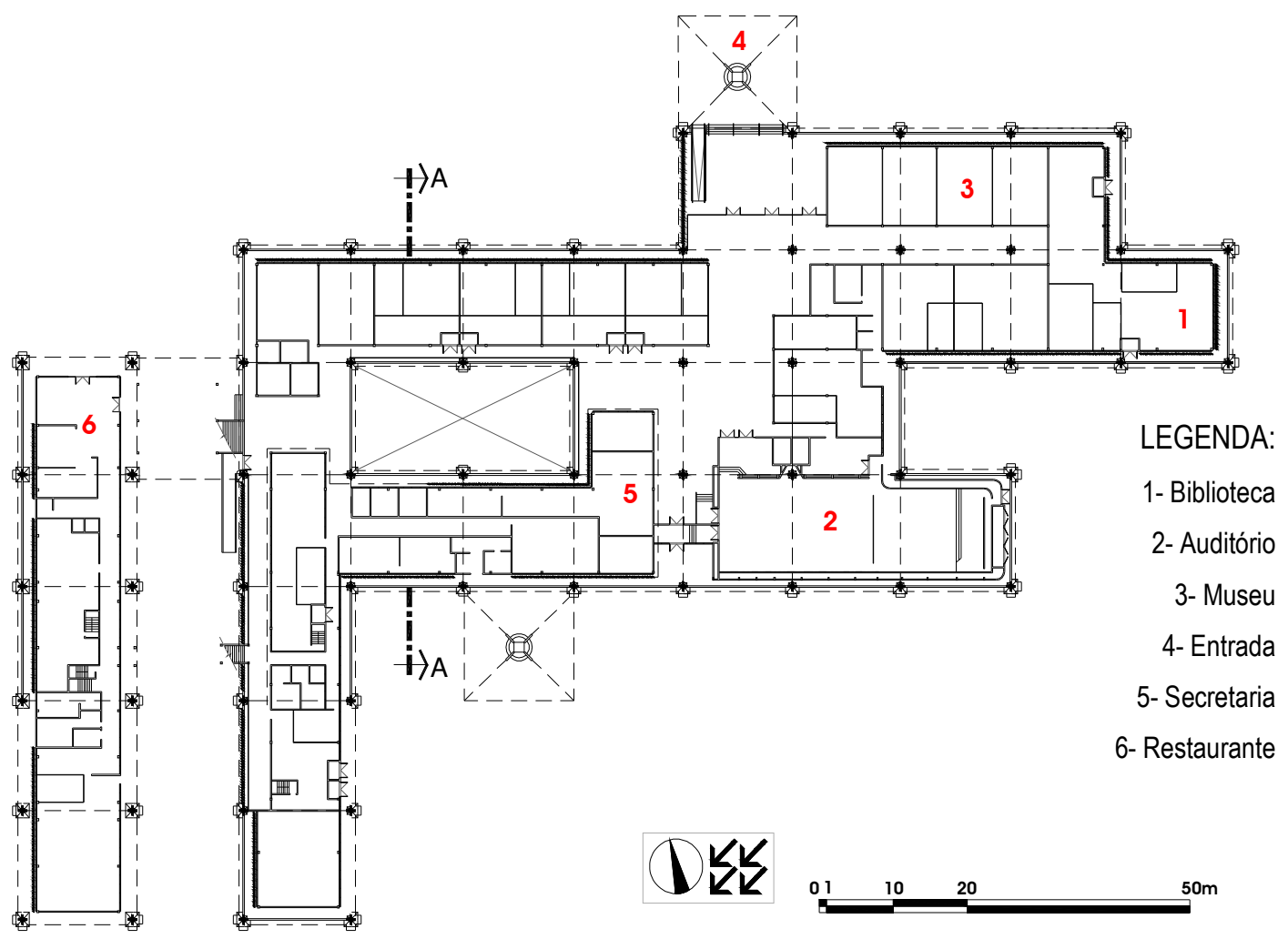

Figura 9.2: Planta pavimento térreo - projeto de reforma de 1995

\subsubsection{Sistema construtivo e materiais}

Para Severiano, a escolha do material adotado em cada projeto era de acordo com o partido que julgasse adequado para o programa dado. Ele acreditava que a construção de um distrito industrial em 
madeira no meio da selva amazônica iria colocar o empreendimento em descrédito no exterior. Por isso, contrariou todas as expectativas e projetou o edifício em concreto, o que, segundo o arquiteto, passaria a imagem de algo mais sólido e permanente, de forte presença governamental: "[...] a preocupação de que fosse uma solução que levasse o mundo a acreditar que 0 distrito industrial ia ser pra valer, não era uma coisa temporária." (PORTO, 2003; informação verbal). Psicologicamente, para ele, o concreto comunica uma impressão de força e estabilidade.

Partindo do princípio de garantir a possibilidade de aumentar a área construída conforme a necessidade e permitir a flexibilidade de arranjo dos espaços, o sistema construtivo escolhido para o conjunto foram módulos estruturais de $15 \mathrm{~m} \times 15 \mathrm{~m}$, independentes entre si, em concreto aparente. Assim, 0 arquiteto pôde projetar grandes vazios, que poderiam ser ocupados de acordo com o layout necessário, quando o programa fosse sendo definido com maiores detalhes. A cobertura é um domo solto, feito de concreto e coberto com fiber glass na abertura, apoiado apenas nos pilares. Com isso, 0 aumento da área construída poderia ser feito pelo acréscimo de novos módulos, conforme a necessidade. A cobertura foi o único elemento que pôde ser inteiramente reaproveitado após o incêndio.
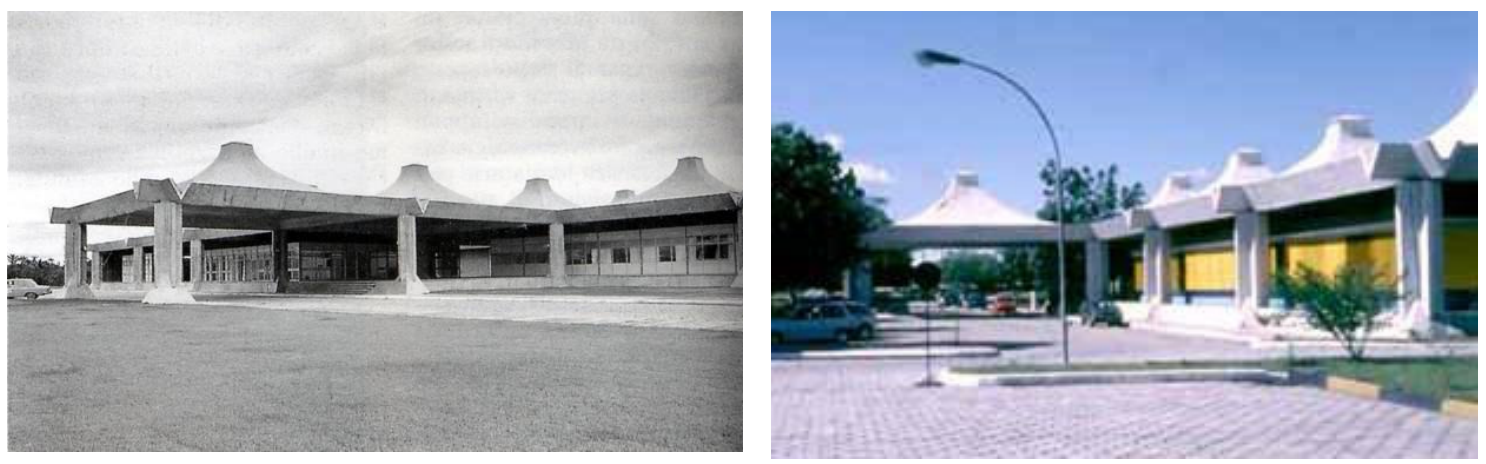

Figuras 9.3 e 9.4: Vista da cobertura antes e após a reforma - área de entrada da Suframa (SEGAWA, 1993; SABBAG, 2003)

As salas administrativas e demais ambientes fechados são independentes da cobertura do edifício (figuras 9.7 e 9.9). Para sua construção, foi utilizada uma estrutura em concreto, com laje também em concreto e vedações em alvenaria e estrutura metálica leve. No projeto de reforma, realizado em 1995, procuraram ser resolvidos os problemas detectados pelos usuários da antiga edificação. Uma importante modificação foi a instalação de refrigeração artificial em todos os ambientes fechados, sendo que apenas as áreas de circulação continuam funcionando com ventilação natural. Foram também adicionados brises móveis às vedações externas, que não constavam no projeto original. 


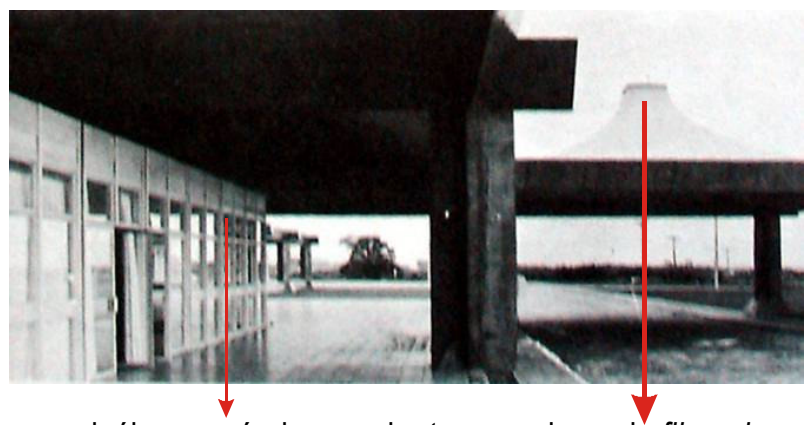

painéis removíveis cobertura em domo de fiber glass

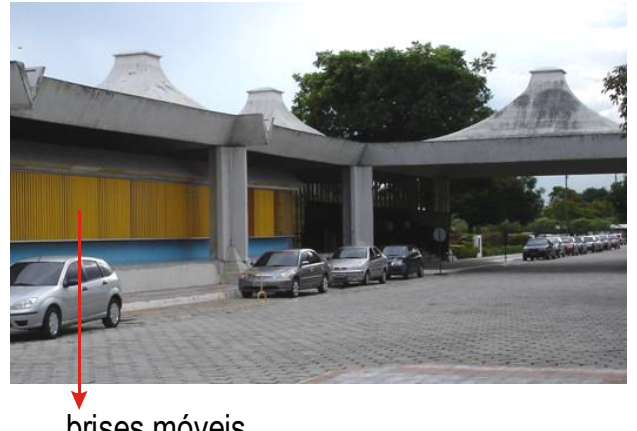

brises móveis

Figuras 9.5 e 9.6: Ambientes fechados abaixo da cobertura, antes (PROJETO, 1982b) e após reforma

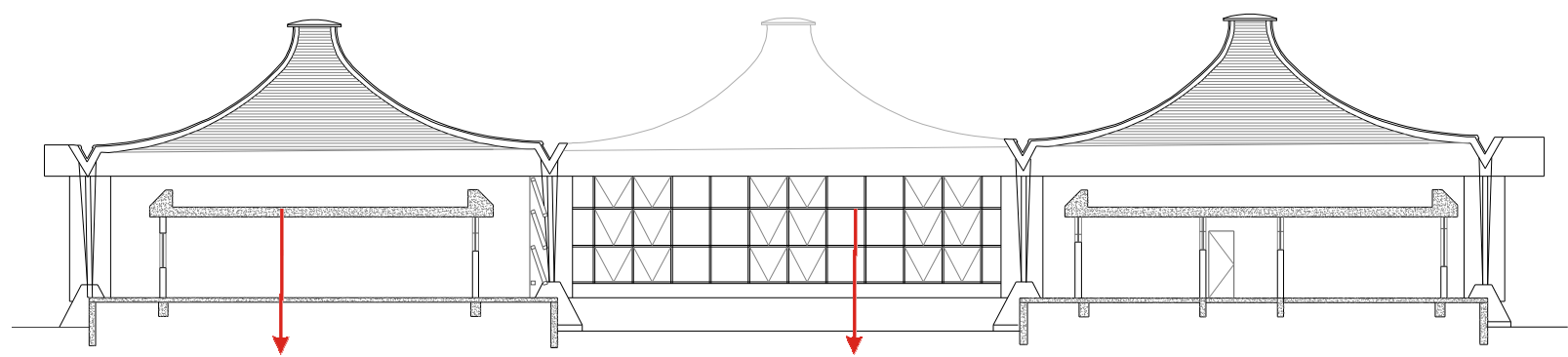

estrutura interna independente da cobertura aberturas que dão para o jardim interno

Figura 9.7: Corte AA - indicação na planta

O entorno próximo é caracterizado pela cobertura vegetal do próprio conjunto, constituída por canteiros de grama e algumas árvores, e pavimentação em blokret, que compõe a área de circulação de automóveis e estacionamentos (figura 9.8).

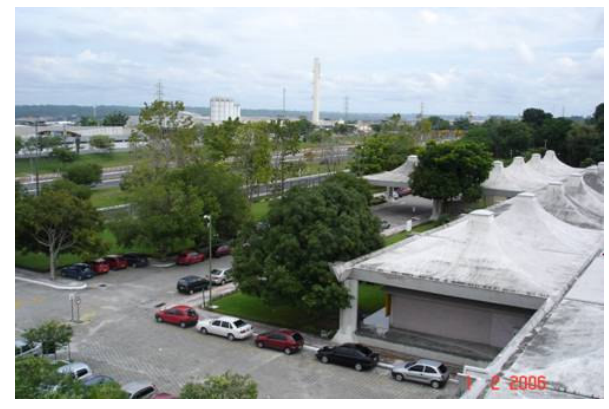

Figura 9.8: Vista aérea ao Norte do edifício da Suframa

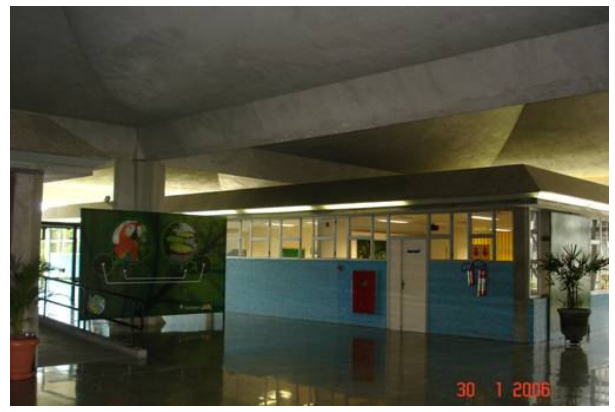

Figura 9.9: Ambiente fechado independente da cobertura 


\subsubsection{Estratégias bioclimáticas e conforto ambiental: ventilação natural}

No projeto deste edifício, Severiano Porto procura adequar-se às características climáticas do local através da exploração das possibilidades dadas pelo material. Numa região onde a temperatura média raramente é inferior a $26^{\circ} \mathrm{C}$, o uso moderado de iluminação natural e o emprego de ventilação natural são estratégias recorrentes em seus projetos. " 'Independentemente dos materiais, os trópicos exigem uma arquitetura que respeite a natureza e preste atenção na força do sol, da chuva e dos ventos', diz Severiano Porto." (GOMES, 1985). Por isso, partindo da intenção inicial (no projeto de 1973) de haver pouco uso de ar condicionado, foram projetados módulos de concreto em forma de tronco de pirâmide oca que funcionam como coifas para tiragem do ar, atuando como efeito chaminé, em solução integrada ao sistema estrutural do projeto.

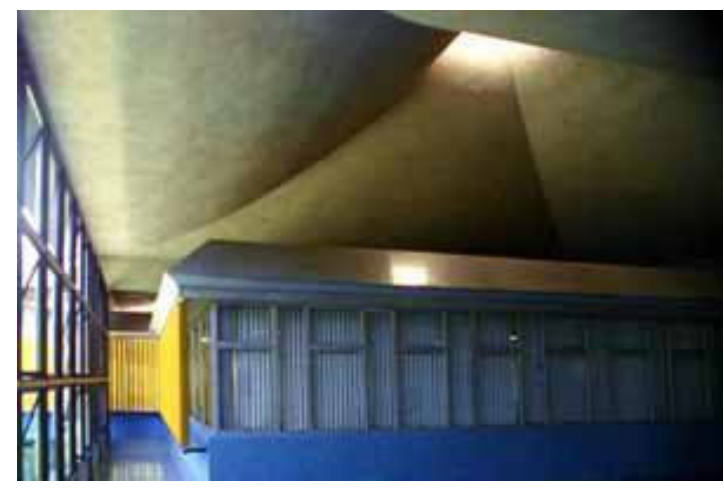

Figura 9.10: Vista interna da coifa (SABBAG, 2003)

Para proteção da insolação direta, a intenção foi fazer uma área coberta contínua de grandes proporções. Com uma cobertura plana, não haveria uma boa exaustão do ar aquecido devido à reduzida distância vertical. A coifa pôde ampliar essa distância vertical e proporcionar a eliminação do ar mais quente pela cobertura. Porto optou pelo módulo de $15 \mathrm{~m}$ em planta, o que, segundo ele, resultaria em um bom espaço para 0 ar quente ser eliminado. "Com a forma adotada poderíamos ter tiragens parciais e foi essa a orientação que se deu - fizemos umas coifas com pequenas aberturas no alto." (Severiano Porto in CZAJOWSKI, 1976) ${ }^{25}$. Desta forma, a cobertura adquire, além da função de cobrir e proteger das chuvas, o papel de climatizar os ambientes. Calhas em sua periferia captam e direcionam a água da chuva.

25 Entrevista exclusiva cedida por Severiano Porto a CZAJOWSKI, 1976. 
Porém, a estrutura utilizada na cobertura não permite uma proteção adequada às fachadas onde ocorre maior incidência de radiação solar. Por isso, no projeto de reforma foram instalados brises externos em todas as fachadas transparentes. Os brises estão a uma distância de $30 \mathrm{~cm}$ das paredes e possuem $1,90 \mathrm{~m}$ de altura por $15 \mathrm{~cm}$ de largura, como pode ser visto na figura 9.13. São brises verticais móveis, que podem ser manipulados conforme a necessidade de proteção do recinto. Segundo os usuários do edifício, a luminosidade natural atrapalha o trabalho, pois incide diretamente sobre as telas dos computadores, por isso a maioria dos brises fica constantemente fechada e as luzes dos ambientes internos ficam acesas. Da forma como foram instalados e são utilizados, estes brises barram o fluxo de ar natural, quando, no entanto, estes elementos deveriam proteger as aberturas da radiação solar direta, porém sem fazer destas proteções obstáculos aos ventos.
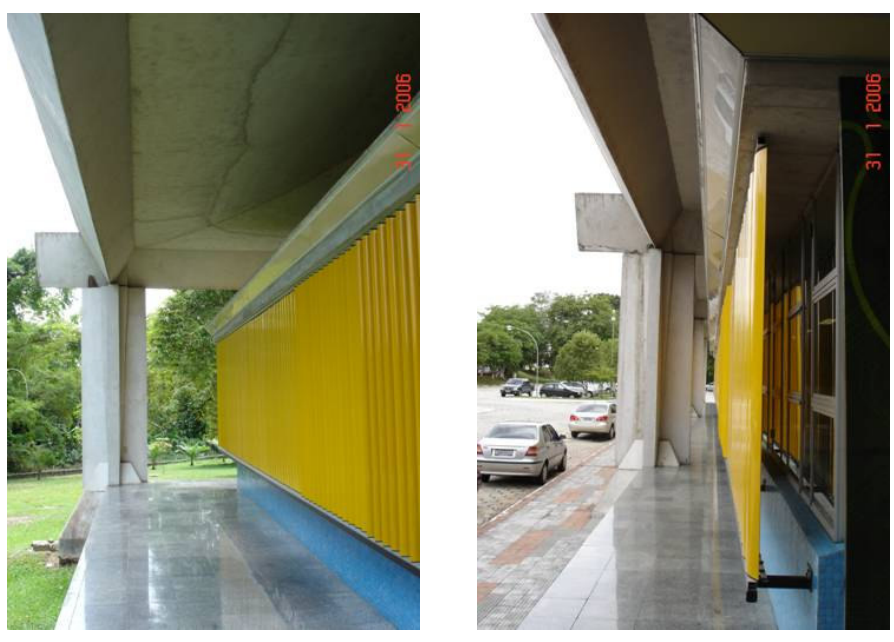

Figuras 9.11 e 9.12: Brises - vista frontal e lateral

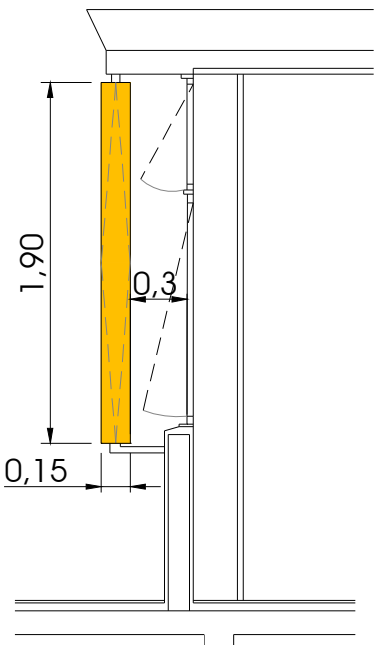

Figura 9.13: Esquema dos brises

Os ambientes fechados abaixo da cobertura possuem aberturas em laterais opostas, visando proporcionar ventilação cruzada. Existem dois tipos de esquadrias nestas vedações (figuras 9.14 e 9.17) - a número 1 é de uma folha com dobradiça, que possui abertura total para o lado externo; as números 2 e 3 são tipo máximo ar, com sistema de abertura também para o lado externo. As aberturas do tipo máximo ar não são recomendadas para ventilação natural, por sua área real de abertura ser muito reduzida. Juntamente com a barreira provocada pelos brises, as esquadrias contribuem para que os ambientes fechados não possuam sistema de ventilação cruzada adequado, o que poderia funcionar como uma alternativa ao sistema de ar condicionado. 

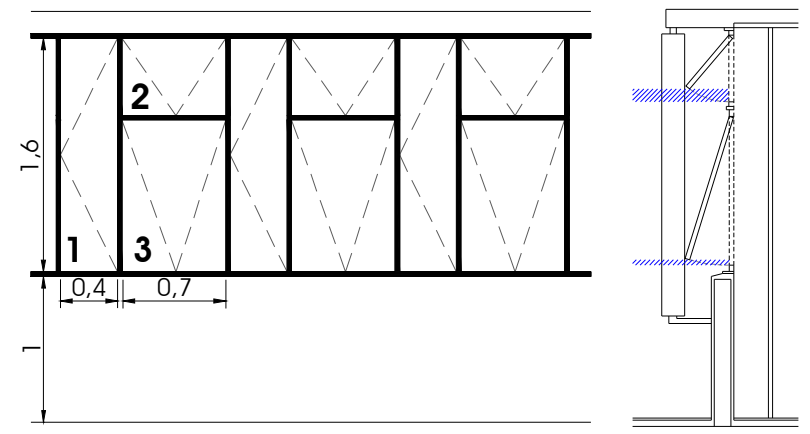

Figuras 9.14 e 9.15: Esquema das esquadrias externas (vista e corte), indicando área real de abertura em azul

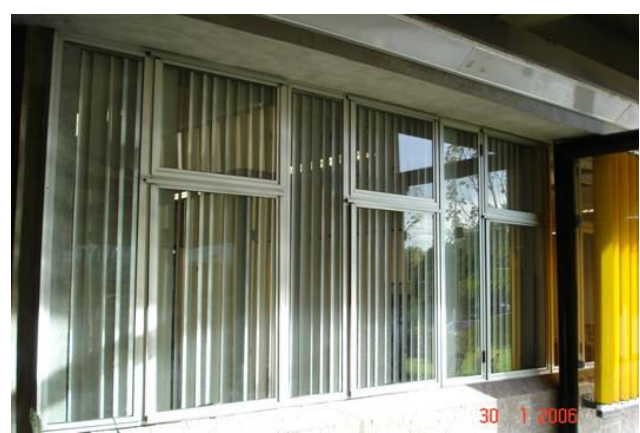

Figura 9.16: Esquadrias externas

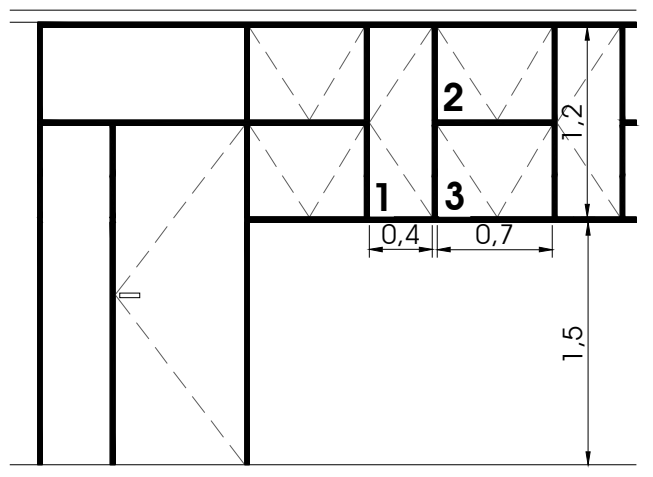

Figura 9.17: Esquema das esquadrias internas - vista

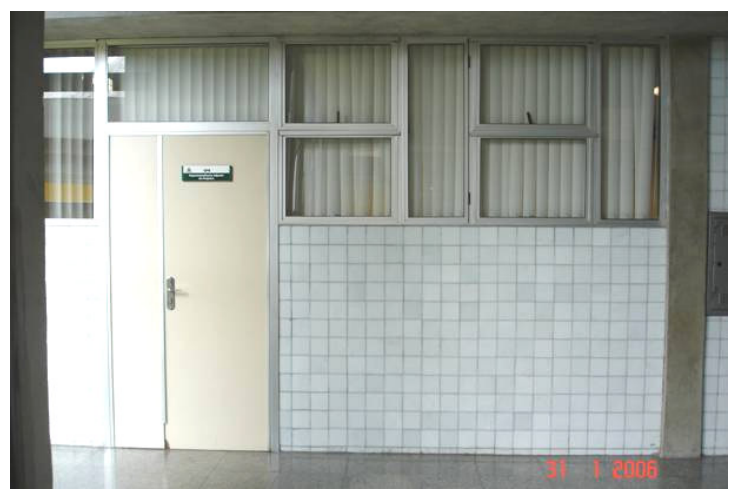

Figura 9.18: Esquadrias internas

Após a reforma, foram realizados fechamentos nas divisões entre os ambientes cobertos e os jardins, para evitar a entrada de água da chuva. São esquadrias feitas em estrutura metálica e vidro, que possuem pequenas aberturas na parte inferior, com $22 \mathrm{~cm}$ de largura. Estas aberturas também obstruem a ventilação natural, pois o vidro barra o fluxo de ar e a área aberta não permite circulação de ar, como pode ser visto na figura 9.19 . 

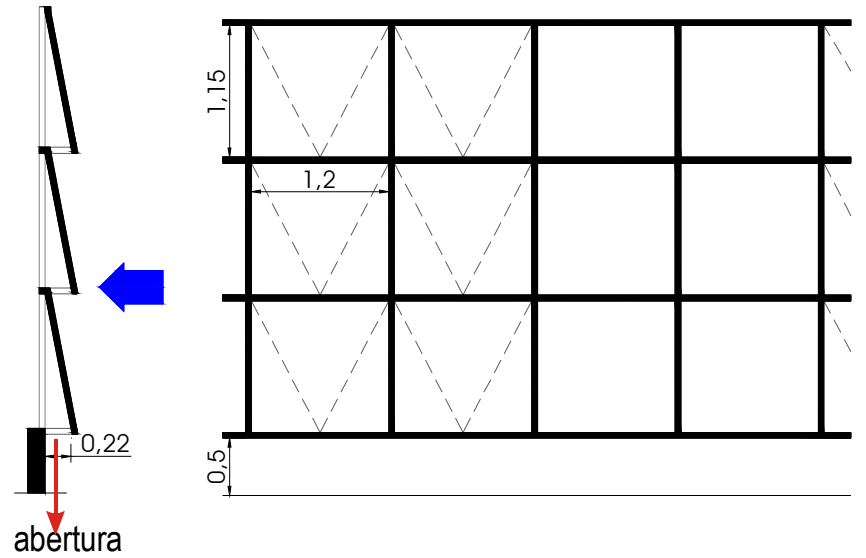

Figuras 9.19 e 9.20: Esquema das esquadrias dos jardins corte e vista

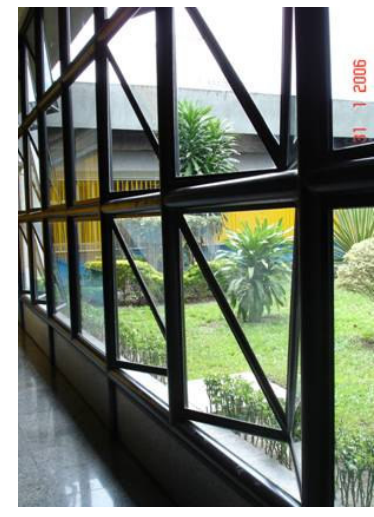

Figura 9.21: Esquadrias dos jardins

O sistema de cobertura em forma de coifa possui uma parte translúcida em cima - um domo em fiber glass de 1,3m x 1,4m - que, além de proporcionar uma leve iluminação interna deveria funcionar como abertura de saída do ar para ventilação. Sabe-se que para um bom funcionamento do efeito chaminé dois fatores primordiais são a diferença de altura entre a entrada e a saída do ar, que determina o gradiente de temperatura entre a parte mais baixa e a mais alta das aberturas; e o tamanho das aberturas de entrada e saída do ar.

O pé-direito varia de $3,85 \mathrm{~m}$ a $8,70 \mathrm{~m}$, entre 0 início e o final da coifa, o que inicialmente pode ser uma boa altura para que ocorra ventilação. Porém, a área da abertura de saída do ar é muito pequena, o que prejudica a ventilação. Esta área foi reduzida no projeto de reforma, em relação ao projeto original, pois antes do incêndio os ambientes internos eram atingidos pela água, que entrava pela abertura zenital em dias de chuva de vento. Após o rebaixamento dos domos, as aberturas de saída do ar das coifas ficaram com apenas $10 \mathrm{~cm}$ de altura, o que dificulta a circulação do ar, como pode ser observado na figura 9.24. Também contribui para isto a proteção lateral do domo, que faz com que 0 ar tenha que percorrer um trajeto sinuoso antes de atingir a área externa. Sabe-se que a menor abertura é que determina a velocidade do fluxo de ar em um ambiente. Por isso, com esta abertura de saída do ar, a ventilação natural é praticamente inexistente. 

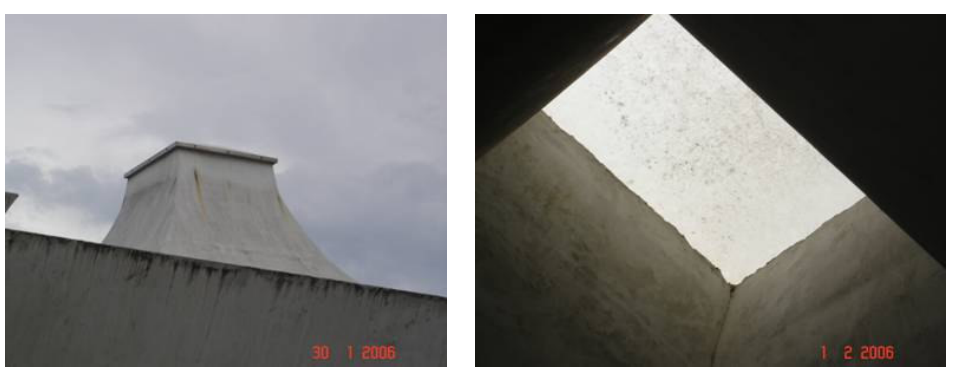

Figuras 9.22 e 9.23: Vistas externa e interna da coifa

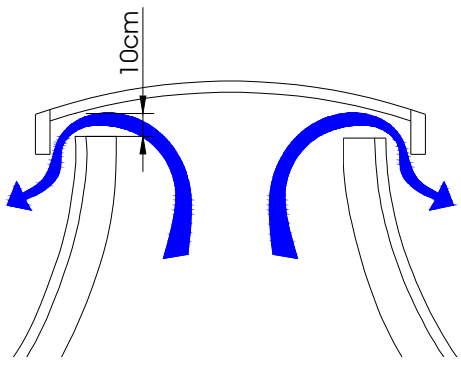

Figura 9.24: Esquema de circulação de ar na coifa

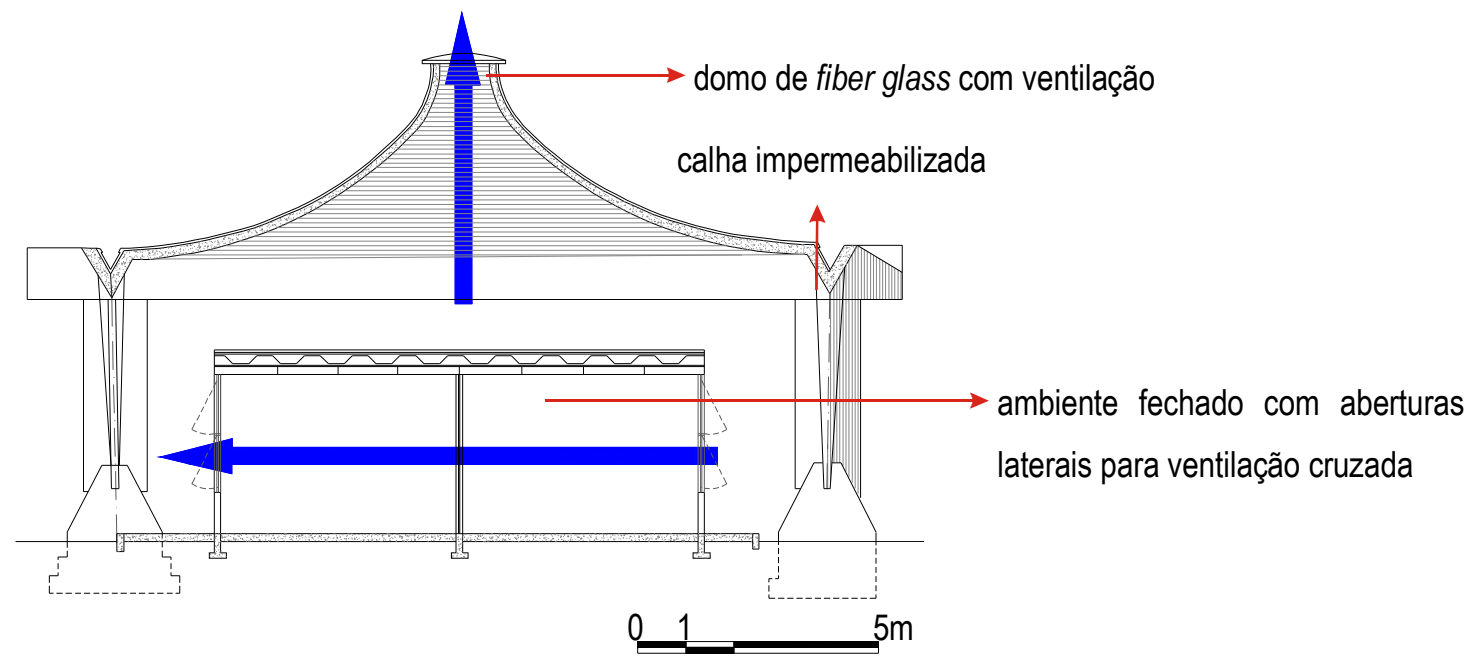

Figura 9.25: Corte indicando sistema de ventilação

O sistema de ventilação natural proposto é extremamente simples, o que, com o auxílio do controle na incidência de radiação solar, visava inicialmente garantir bons níveis de conforto térmico ao ambiente interno sem a utilização de refrigeração artificial. No entanto, alguns itens importantes faltaram ser observados, para que realmente houvesse ventilação por efeito chaminé. 0 acompanhamento por uma equipe de consultoria especializada na etapa projetual seria de grande importância.

Uma conseqüência da falta de funcionamento do projeto de ventilação natural foi a instalação de refrigeração artificial em todos os ambientes fechados do conjunto. Com isso, as coifas para tiragem do ar da cobertura perderam sua função original em todos os espaços fechados, que apresentam fechamento em laje de concreto, por onde passam todas as instalações prediais. A falta de conhecimento técnico sobre o assunto prejudicou o projeto como um todo, que acabou resultando em uma resolução meramente formal, já que as coifas não exercem a função a que foram inicialmente 
projetadas.

O concreto, material escolhido para a construção da cobertura, possui elevada inércia térmica e não é adequado ao clima quente e úmido da região, por armazenar grande quantidade de calor ao sofrer incidência direta da radiação solar (caso da cobertura) e transmitir parte dele ao ambiente interno. Por isso, alguns elementos poderiam ter sido trabalhados com maior atenção neste projeto, para amenizar os efeitos negativos do concreto. Poderiam ter sido escolhidas, por exemplo, esquadrias com uma maior área real de abertura, para favorecer a ventilação cruzada. Uma abertura zenital maior poderia garantir o funcionamento do efeito chaminé, que é uma estratégia de projeto adequada para o clima. 0 uso de beirais que protegessem as fachadas de maior insolação (Leste e Oeste) poderia reduzir a necessidade de brises, que obstruem o fluxo de ar natural.

Através da análise descritiva de projeto do edifício da Suframa foram detectadas lacunas no detalhamento de diversos itens, que influenciam no desempenho geral do sistema de ventilação proposto - que alia ventilação cruzada e efeito chaminé, uma solução adequada ao clima. $O$ uso de concreto aparente em grande quantidade, apesar da justificativa dada pelo arquiteto, é uma solução não recomendada ao clima quente e úmido e afeta o desempenho térmico do edifício como um todo.

\subsubsection{A Suframa hoje}

O edifício da Suframa está implantado em um sítio onde a urbanização até hoje apresenta baixos índices de ocupação e de densificação. Além de algumas empresas e indústrias instaladas na região, observa-se a presença de vegetação nativa, principalmente na área ao Sul da Suframa, onde passa o rio. Este fato é vantajoso para a ocorrência de ventilação natural, pois áreas urbanas de elevada densidade podem barrar o fluxo de ar e reduzir a intensidade dos ventos dominantes locais. No geral, 0 edifício se encontra em ótimo estado de conservação. A cobertura de concreto é pintada de branco, 0 que auxilia na reflexão da radiação solar e mantém sua temperatura superficial mais baixa, contribuindo para a melhoria do conforto térmico interno. 

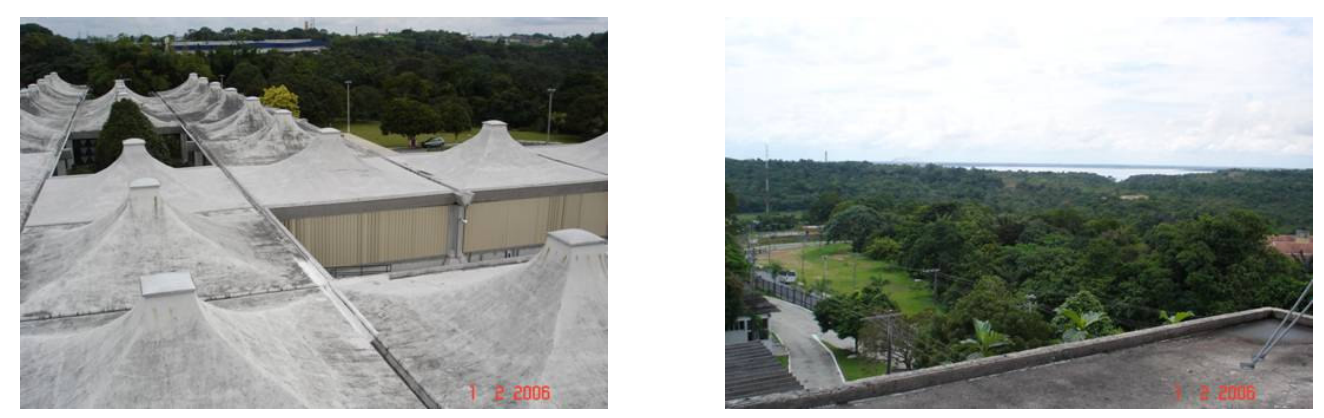

Figuras 9.26 e 9.27: Entorno do edifício da Suframa: vistas Leste e Sudoeste

\subsection{ANÁLISE QUANTITATIVA}

A pesquisa de campo no edifício da Suframa foi realizada no período de 30 de janeiro a 6 de fevereiro de 2006. Os equipamentos de medição de temperatura e umidade foram dispostos em três pontos de duas áreas de circulação internas do edifício, que não possuem ar condicionado: a primeira área é a entrada principal do edifício, onde estão localizados os pontos 1 e 2; a segunda área situa-se a Oeste do jardim interno e interliga o edifício principal ao anexo, onde está o ponto 4 . 0 ponto 3 está localizado sob a cobertura de embarque e desembarque, na entrada principal do edifício. 0 ponto 5 está situado em um local fora do edifício principal, próximo à garagem do conjunto. A posição dos pontos pode ser vista na figura 9.28 .

Pode-se observar que os pontos 1 e 2 estão na mesma posição em planta, porém em níveis diferentes, para verificação das alterações provocadas pela diferença de altura no gradiente de temperatura - 0 ponto 1 está a 3,5m de altura (sobre a laje de um ambiente fechado) e o ponto 2 está no nível do piso (figura 9.29). Foram realizadas medições ininterruptamente pelo período de uma semana, em intervalos de 15 minutos.

Para uma análise mais detalhada de ventilação natural, foram escolhidas as duas áreas de circulação internas acima descritas, já que todos os ambientes fechados do edifício possuem ar condicionado. As medições de velocidade do ar foram realizadas em horários alternados, durante cinco dias da semana. 


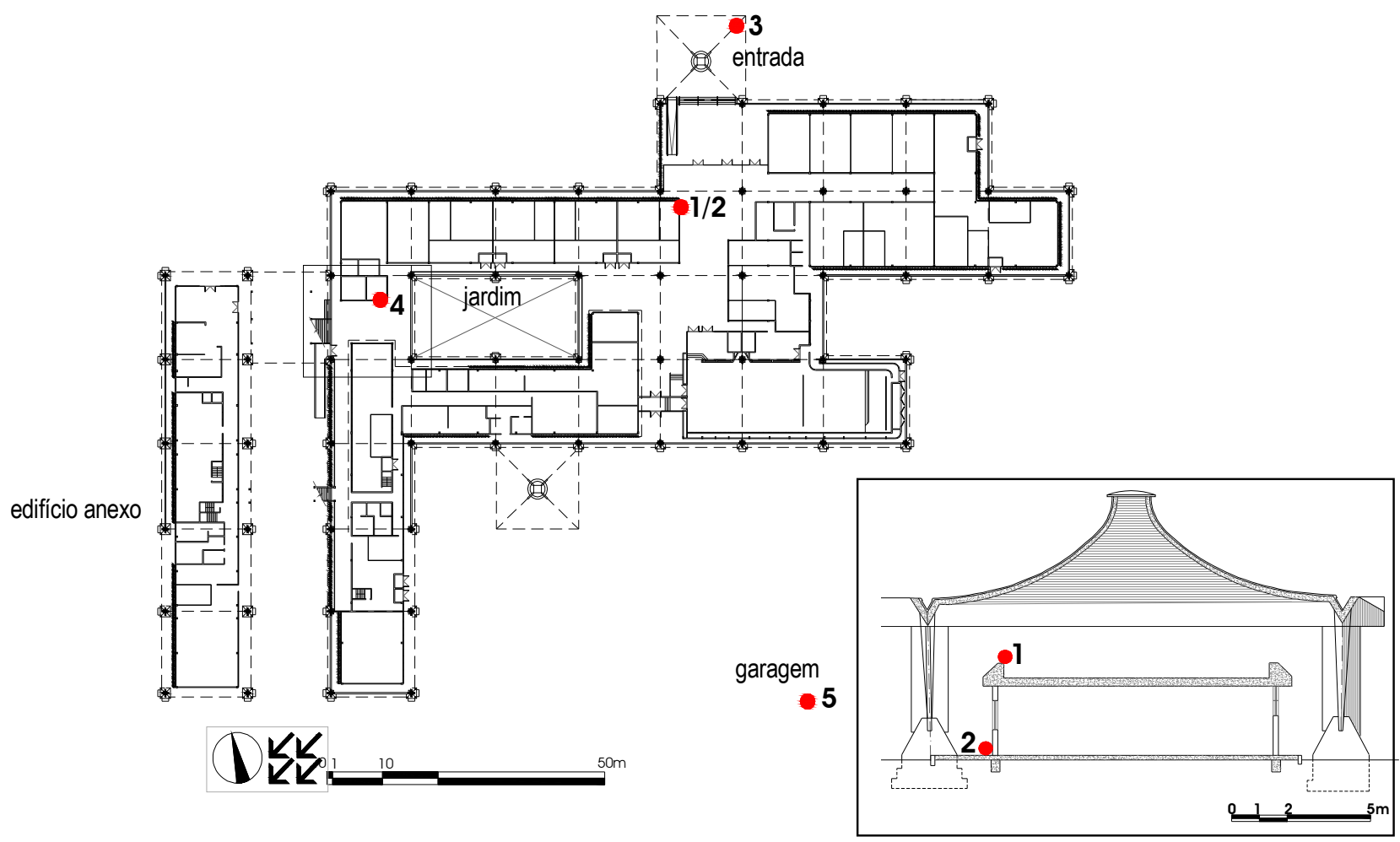

Figuras 9.28 e 9.29: Indicação dos pontos onde foram instalados os equipamentos de medição de temperatura e umidade - planta e corte

\subsubsection{Caracterização dos ambientes escolhidos para análise}

Este item realiza uma descrição detalhada das áreas de circulação escolhidas para análise, com o objetivo de dar subsídios à leitura e interpretação dos dados obtidos.

\subsubsection{Entrada principal do edifício}

A entrada principal da Suframa possui um módulo de cobertura sem vedações laterais, que funciona como área de embarque e desembarque (figura 9.30), seguido por um desnível e uma vedação composta por uma estrutura metálica de $2,5 \mathrm{~m}$ de altura e três portas de vidro (figura 9.31), que separam o ambiente interno do externo. Apenas uma das portas de vidro, ao lado da guarita, estava constantemente aberta para circulação no período das medições de velocidade do ar. 

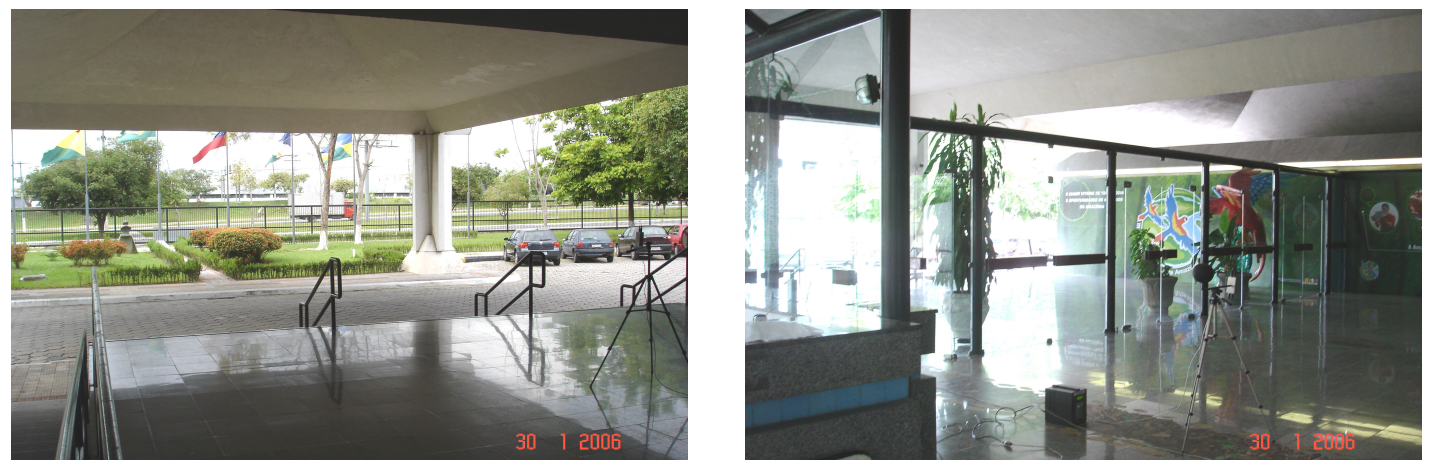

Figuras 9.30 e 9.31: Entrada da Suframa

As portas de vidro, que são as aberturas de entrada do ar, possuem 1,90m de largura por 2,10m de altura, e acima disso o espaço fica aberto para fluxo livre do ar. Logo após esta divisória existe um espaço interno de circulação, onde os ambientes fechados situam-se nas duas laterais, a uma distância de $13,60 \mathrm{~m}$ um do outro na área mais próxima à entrada, e mais ao fundo a uma distância de $8,70 \mathrm{~m}$ (figura 9.33). O pé-direito da área é de $3,85 \mathrm{~m}$ do piso até o início da coifa e 4,85m do início ao fim da coifa, dando um total de $8,70 \mathrm{~m}$ de altura (figura 9.32).

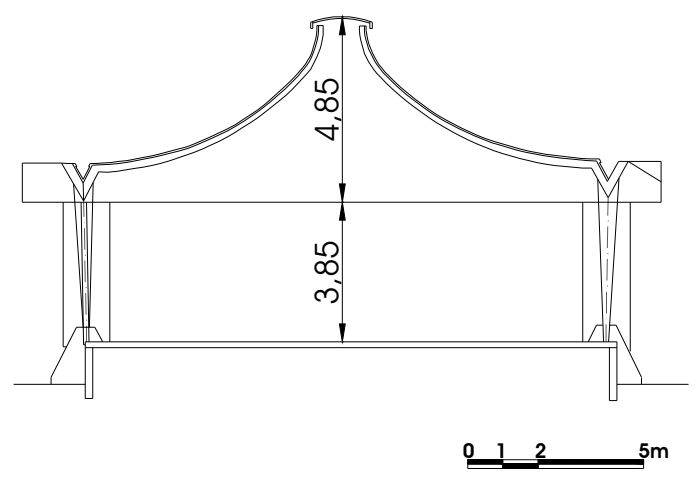

Figura 9.32: Corte esquemático da cobertura

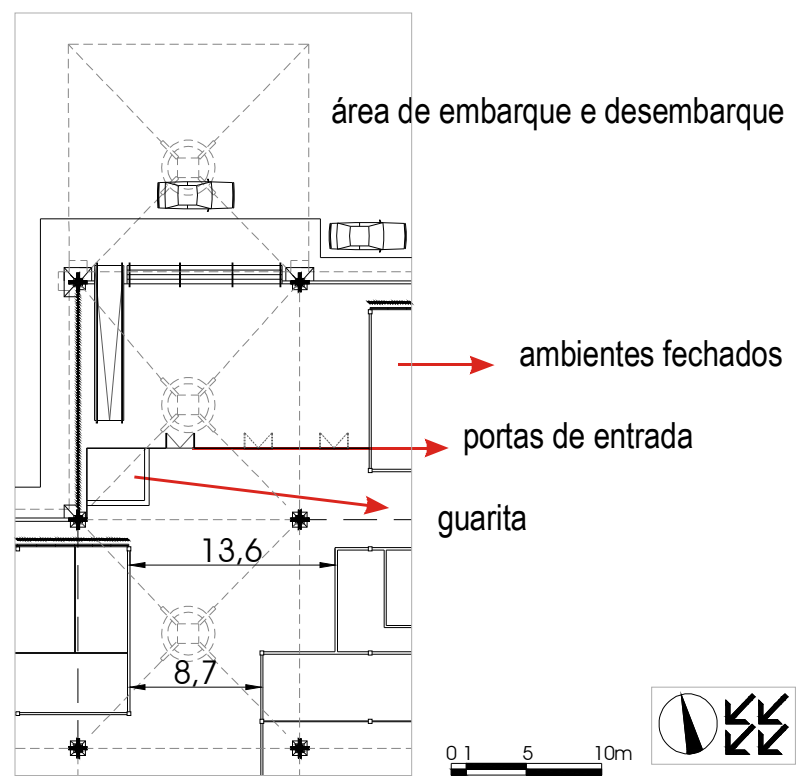

Figura 9.33: Planta da área de entrada do edifício principal

A tabela abaixo apresenta uma especificação detalhada de materiais e revestimentos utilizados na construção de todo o edifício da Suframa, dados necessários para avaliação do desempenho térmico 
da edificação.

Tabela 9.1 - Materiais construtivos e revestimentos das áreas de circulação internas

\begin{tabular}{|l|l|}
\hline \multicolumn{1}{|c|}{ Componente do edifício } & \multicolumn{1}{c|}{ Material } \\
\hline Cobertura em forma de coifa & Concreto aparente \\
\hline Estrutura da cobertura & Concreto aparente \\
\hline Vedações internas & Tijolo cerâmico vazado (esp. 15cm) \\
\hline Revestimento externo das vedações & Pastilha cerâmica \\
\hline Revestimento interno das vedações & Azulejo $10 \mathrm{~cm} \times 10 \mathrm{~cm}$ \\
\hline Revestimento do piso & Granito 40cm x 40cm \\
\hline Esquadrias & Alumínio e vidro incolor comum \\
\hline
\end{tabular}

9.2.1.2 Área de circulação que interliga o edifício principal ao anexo

A outra área de circulação em que foram realizadas medições fica a Oeste do jardim interno e possui uma passagem que interliga tanto à passarela entre 0 edifício principal e 0 anexo quanto à área externa (figura 9.34). Esta passagem, que é a abertura de entrada do ar, possui uma vedação composta por estrutura metálica pintada de branco e vidro incolor, de 2,50m de altura, com espaço livre para fluxo de ar acima dela (figura 9.35). Existem duas portas ligando à área externa, que medem $1,90 \mathrm{~m}$ por $2,10 \mathrm{~m}$ cada, e estavam constantemente abertas durante o monitoramento de velocidade do ar.
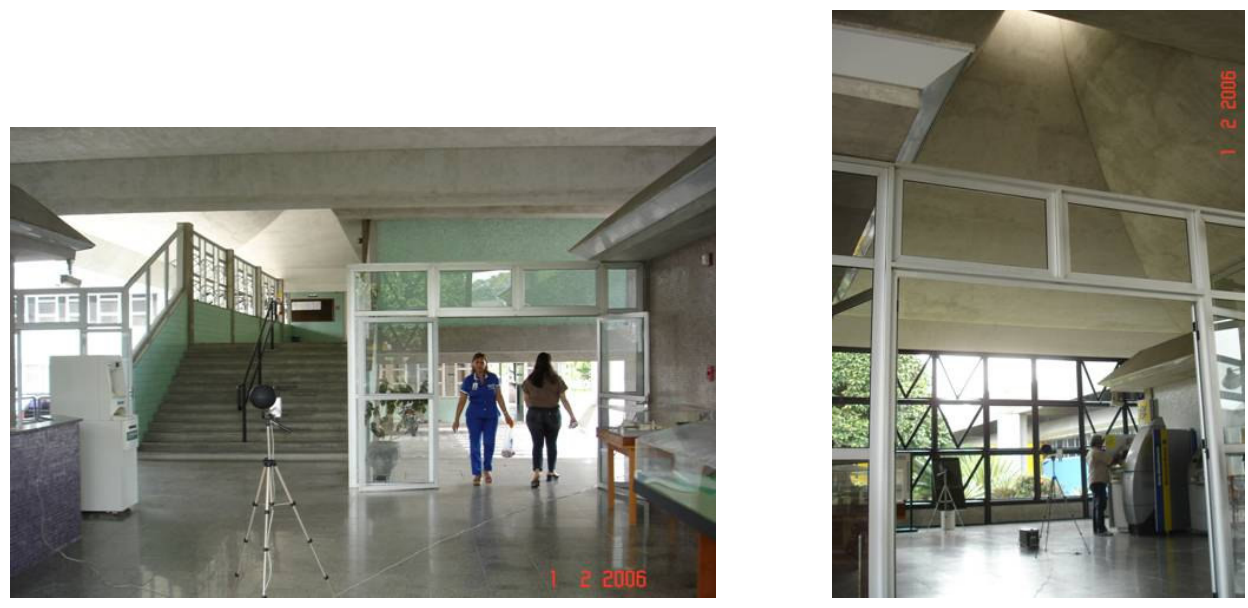

Figuras 9.34 e 9.35: Circulação entre jardim interno e passarela

Do lado oposto à porta, a uma distância de 12,5m, fica o jardim interno (figura 9.36); em suas laterais existem dois corredores, que funcionam como aberturas de saída do ar e medem $3,30 \mathrm{~m}$ e $4,20 \mathrm{~m}$. A distância entre os dois ambientes fechados que compõem o espaço é de 7,30m. A altura do pé-direito é a mesma do ambiente anterior, e se mantém por toda a edificação. A área é de circulação intensa e 
possui dois caixas eletrônicos.

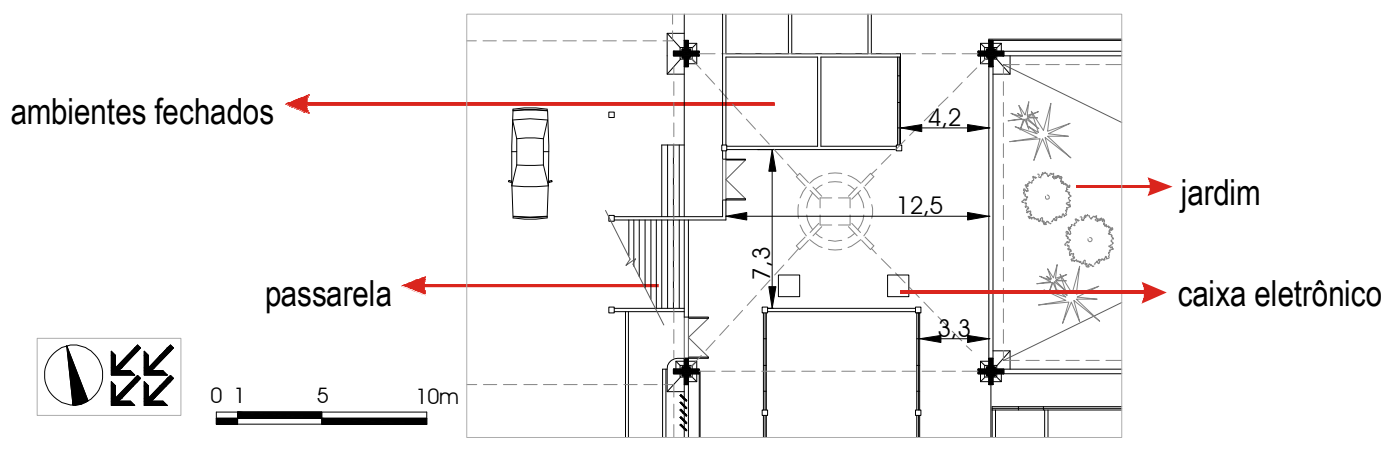

Figura 9.36: Planta da área de circulação entre jardim interno e passarela

\subsubsection{Dados obtidos para temperatura e umidade}

Os dois gráficos apresentados a seguir referem-se aos pontos 1 e 5: o ponto 1 está localizado na área interna da entrada principal e o ponto 5 está localizado na área externa. 0 gráfico 9.1 apresenta os dados de temperatura e o gráfico 9.2 apresenta os dados de umidade.

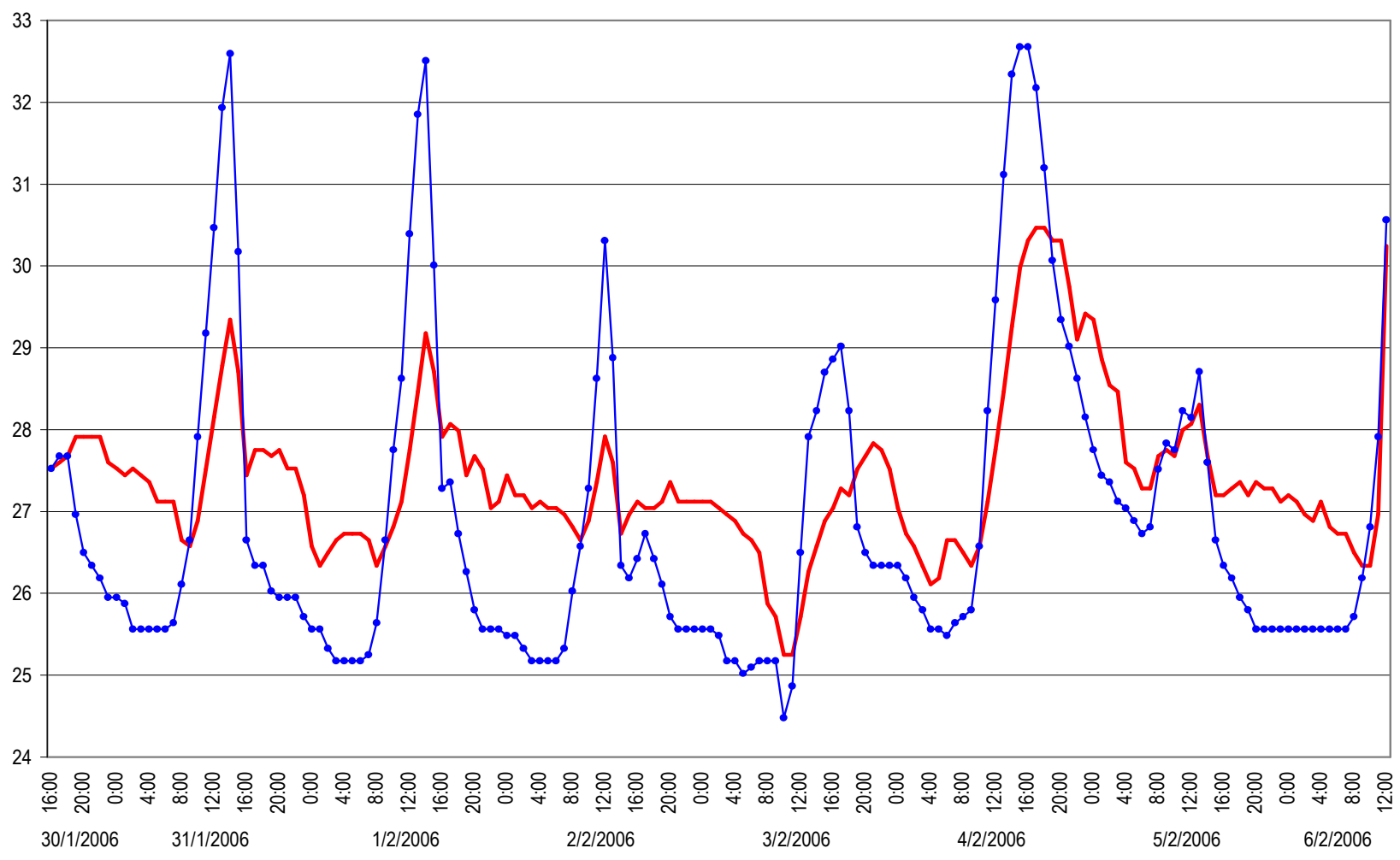

— ponto 1 (entrada principal) Temp. $\left({ }^{*} \mathrm{C}\right) \rightarrow$ ponto 5 (externo) Temp. $\left({ }^{*} \mathrm{C}\right.$ )

Gráfico 9.1: Temperatura do ar $\left({ }^{\circ} \mathrm{C}\right)$ - interno (ponto 1) x externo (ponto 5) 


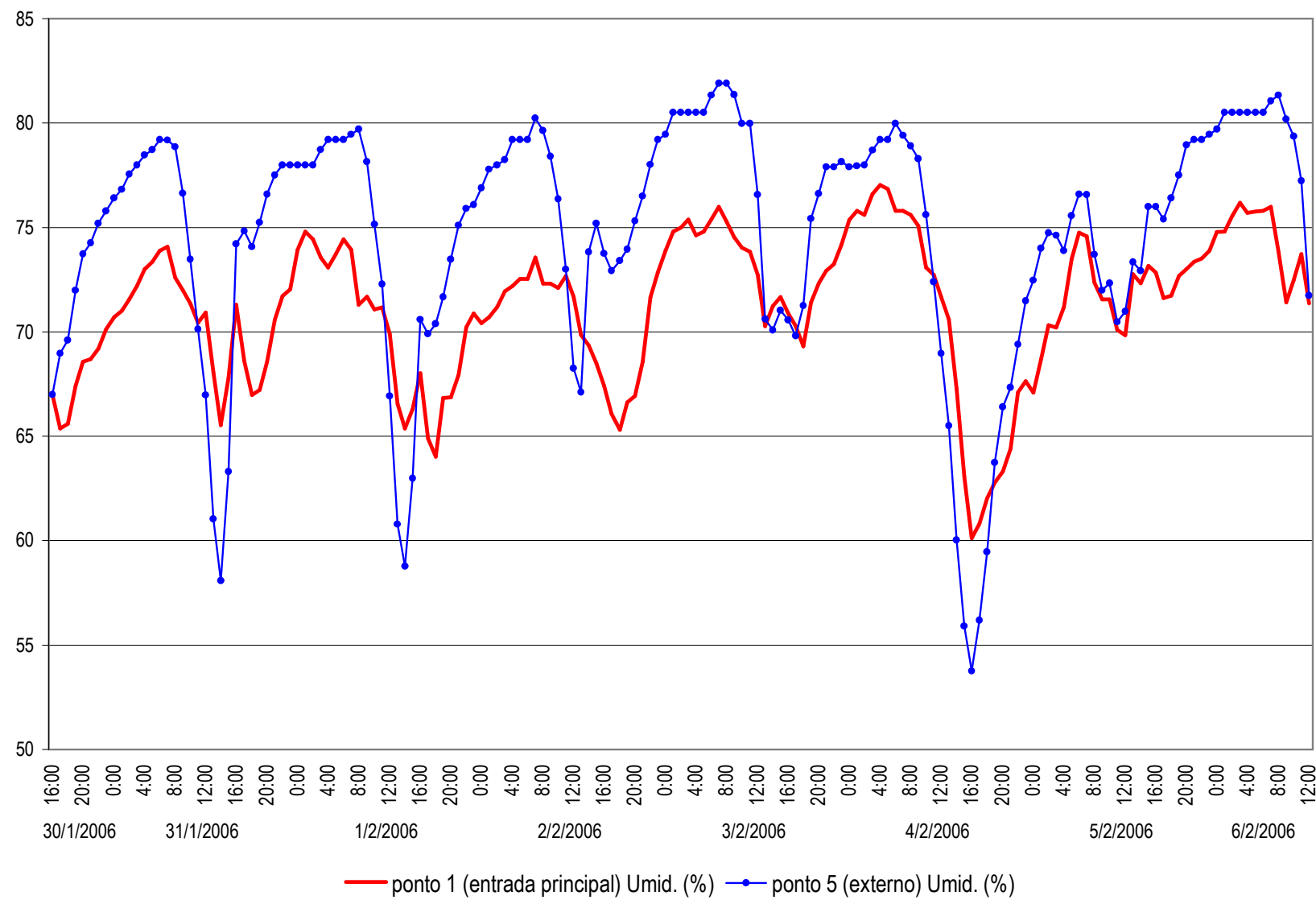

Gráfico 9.2: Umidade relativa do ar (\%) - interno (ponto 1) x externo (ponto 5)

Comparando a variação de temperatura do ambiente interno com a variação externa (gráfico 9.1), observa-se a presença de um amortecimento acentuado. Enquanto externamente a média das máximas foi de $31,4^{\circ} \mathrm{C}$ e a média das mínimas $25,4^{\circ} \mathrm{C}$, na área da entrada principal do edifício (ponto 1) estes valores ficaram em $29,2^{\circ} \mathrm{C}$ e $26,2^{\circ} \mathrm{C}$. As medições realizadas revelam, portanto, um amortecimento médio de $2,2^{\circ} \mathrm{C}$ neste ponto, em relação à temperatura externa, chegando inclusive a valores superiores a $3^{\circ} \mathrm{C}$ nos dias mais quentes.

Observa-se também a presença de atraso térmico, que ficou em torno de $01 \mathrm{~h} 20 \mathrm{~min}$ durante a semana, porém variou bastante de um dia para o outro, chegando a 03h15min no dia 03/02. Durante a semana de medições, a média obtida para a temperatura externa foi de $26,9^{\circ} \mathrm{C}$ e a amplitude média ficou em $6,0^{\circ} \mathrm{C}$. A amplitude média interna (ponto 1 ) foi de $3^{\circ} \mathrm{C}$, metade do valor obtido para variação externa, porém a média da temperatura interna foi superior à externa, e ficou em $27,4^{\circ} \mathrm{C}$. Estas características estão associadas à elevada inércia térmica da construção, já que o material predominante do edifício da Suframa é o concreto armado.

Também houve um certo amortecimento em relação à umidade relativa do ar, cujos valores 
externamente foram de 61,1\% para a média das mínimas (no período da tarde) e 79,9\% para a média das máximas (durante a madrugada), ficando a média semanal em 74,7\%. Já internamente, a média da semana foi próxima à média externa, porém a variação no decorrer do dia foi menor: no ponto 1 , a média das mínimas foi de $64,2 \%$ e a média das máximas 75,7\% (gráfico 9.2).

Os resultados obtidos no monitoramento do ponto 4, situado na área de circulação que liga o edifício principal ao anexo, foram semelhantes ao ponto 1 , como pode-se observar no gráfico seguinte:

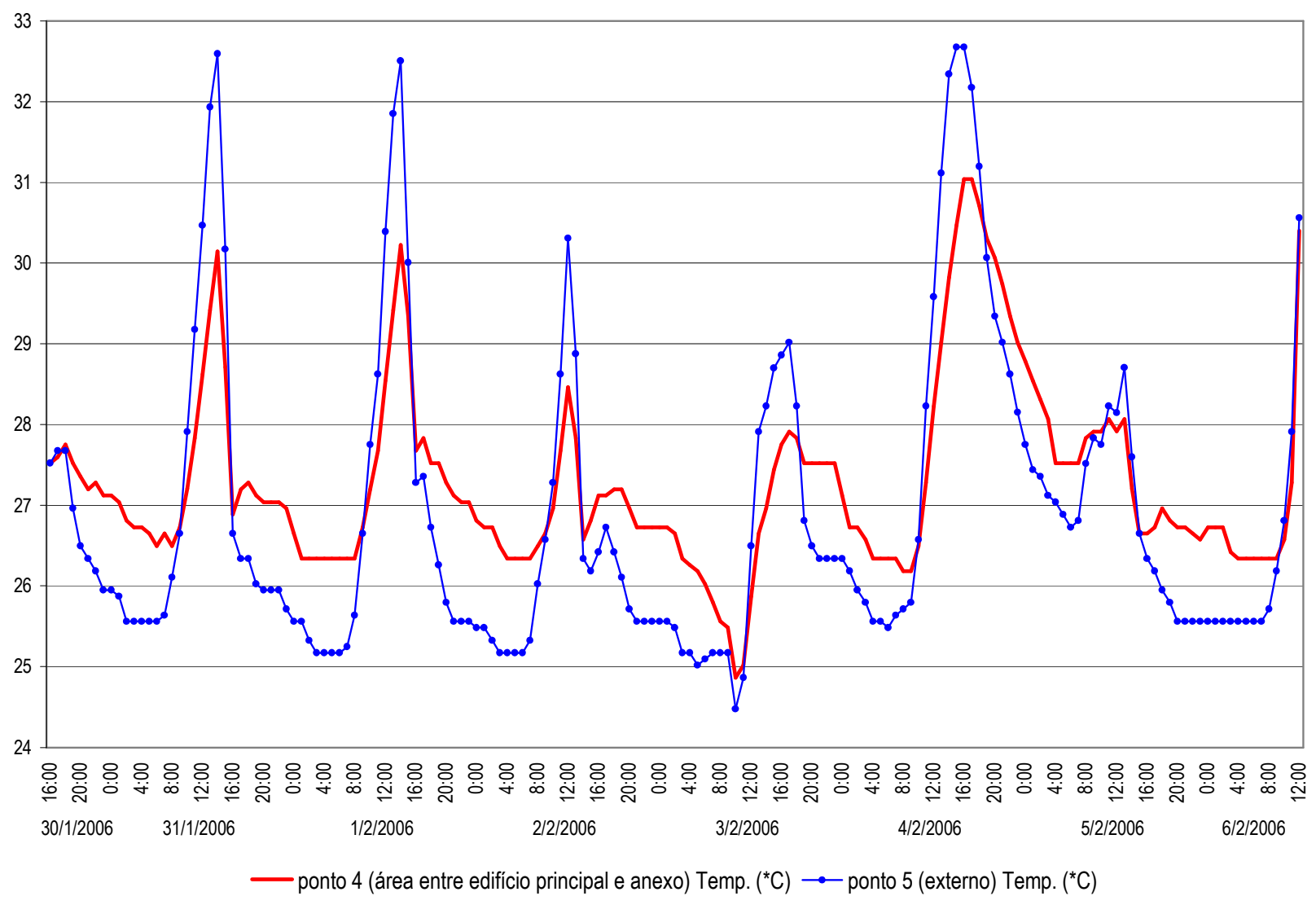

Gráfico 9.3: Temperatura do $\operatorname{ar}\left({ }^{\circ} \mathrm{C}\right)$ - interno (ponto 4) x externo (ponto 5)

Para o ponto 4 , a média das máximas foi de $29,6^{\circ} \mathrm{C}$ e a média das mínimas $26,2^{\circ} \mathrm{C}$, o que também resulta em um amortecimento acentuado em relação à temperatura externa - uma média de $1,8^{\circ} \mathrm{C} .0$ atraso térmico foi de aproximadamente uma hora.

O gráfico 9.4, a seguir, apresenta a comparação dos dados obtidos no ponto externo (ponto 5) com 0 ponto localizado abaixo da cobertura de embarque e desembarque (ponto 3) - área aberta nas laterais, que possui a cobertura de concreto armado em forma de coifa. Apesar de ser uma área aberta, onde as oscilações de temperatura e umidade são maiores do que nos ambientes internos, a simples 
presença da cobertura em concreto já faz com que haja um pequeno amortecimento de temperatura em relação às medições externas - em torno de $0,8^{\circ} \mathrm{C}$.

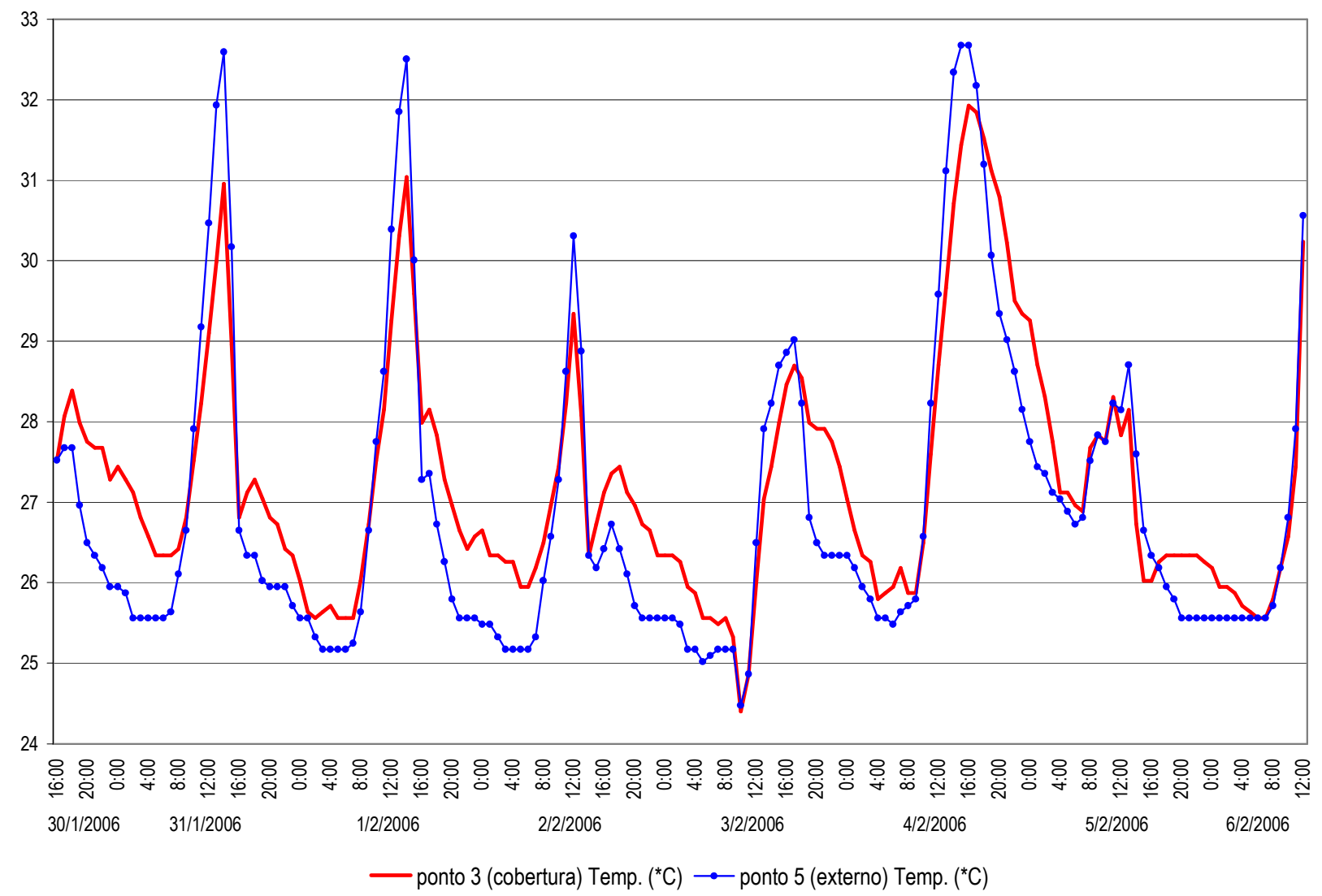

Gráfico 9.4: Temperatura do $\operatorname{ar}\left({ }^{\circ} \mathrm{C}\right)$ - abaixo da cobertura de embarque e desembarque (ponto 3$) \mathrm{x}$ externo (ponto 5)

Para observação da oscilação de temperatura entre diferentes alturas de um mesmo ponto, os pontos 1 e 2 foram dispostos em um mesmo local da área de entrada, porém em diferentes níveis (gráfico 9.5). O ponto 1, localizado a 3,5m de altura, apresenta maiores oscilações em relação ao ponto 2, que está no nível do piso, principalmente nas horas mais quentes do dia. Enquanto os picos de temperatura mínima registrados foram muito próximos nos dois pontos, as temperaturas máximas possuíram diferenças de 2 a $3^{\circ} \mathrm{C}$. As máximas registradas às 17:15hs do dia 04/02, por exemplo, foram de $27,91^{\circ} \mathrm{C}$ no nível do piso e de $30,71^{\circ} \mathrm{C}$ a $3,5 \mathrm{~m}$ de altura, uma diferença de quase $3^{\circ} \mathrm{C}$.

Como um dos fatores primordiais para ocorrência de ventilação por efeito chaminé é a existência de um gradiente de temperatura entre as aberturas de entrada e saída do ar, estes resultados contribuem na análise do sistema de ventilação natural do edifício. A diferença de temperatura encontrada para a altura de 3,5m já foi significativa, e levando-se em consideração que o pé-direito total da edificação é 
de $8,70 \mathrm{~m}$, pode-se concluir que há um gradiente de temperatura interno favorável à ocorrência deste tipo de ventilação natural. As diferenças entre os picos de temperatura máxima podem ser claramente observadas no gráfico a seguir:

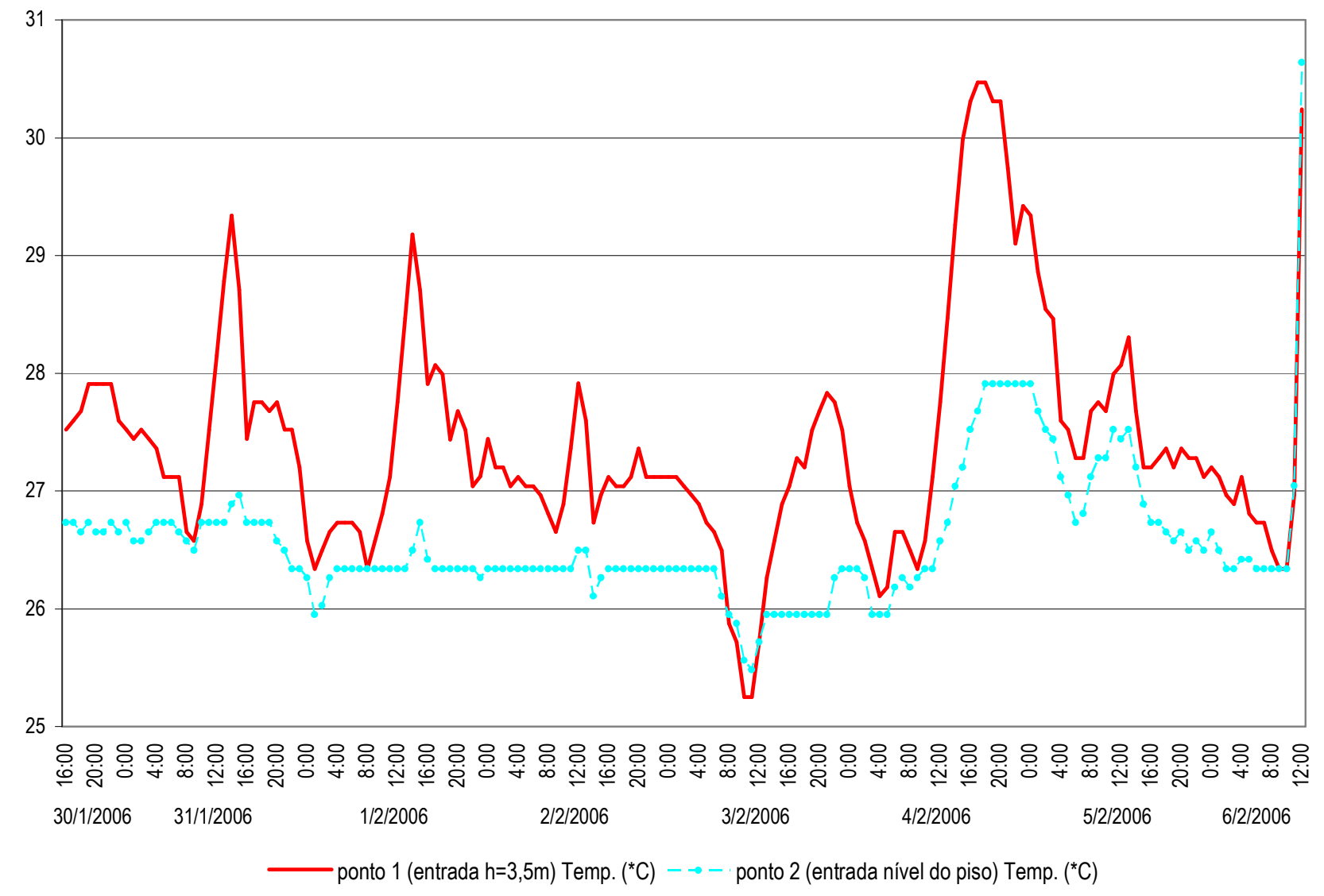

Gráfico 9.5: Temperatura do $\operatorname{ar}\left({ }^{\circ} \mathrm{C}\right)-$ interno $h=3,5 \mathrm{~m}$ (ponto 1) $\mathrm{x}$ interno $\mathrm{h}=0$ (ponto 2)

\subsubsection{Dados obtidos para velocidade do ar}

Como todos os ambientes fechados do edifício da Suframa possuem aparelhos de ar condicionado, foram escolhidos dois espaços abertos, de circulação, para a realização do monitoramento de ventilação natural: a entrada do edifício, situada próxima à fachada Norte (área 1), e a área que liga 0 edifício principal ao anexo, situada próxima ao jardim interno (área 2). A descrição detalhada destes ambientes encontra-se no item 9.2.1. Como são espaços de passagem, não houve ocupantes de longa permanência no período de medições, mas apenas uma certa movimentação de usuários do edifício. As medições foram realizadas a uma altura de $1,20 \mathrm{~m}$ do piso. 
Os resultados obtidos para a área 1 apresentam-se no gráfico e figura a seguir:
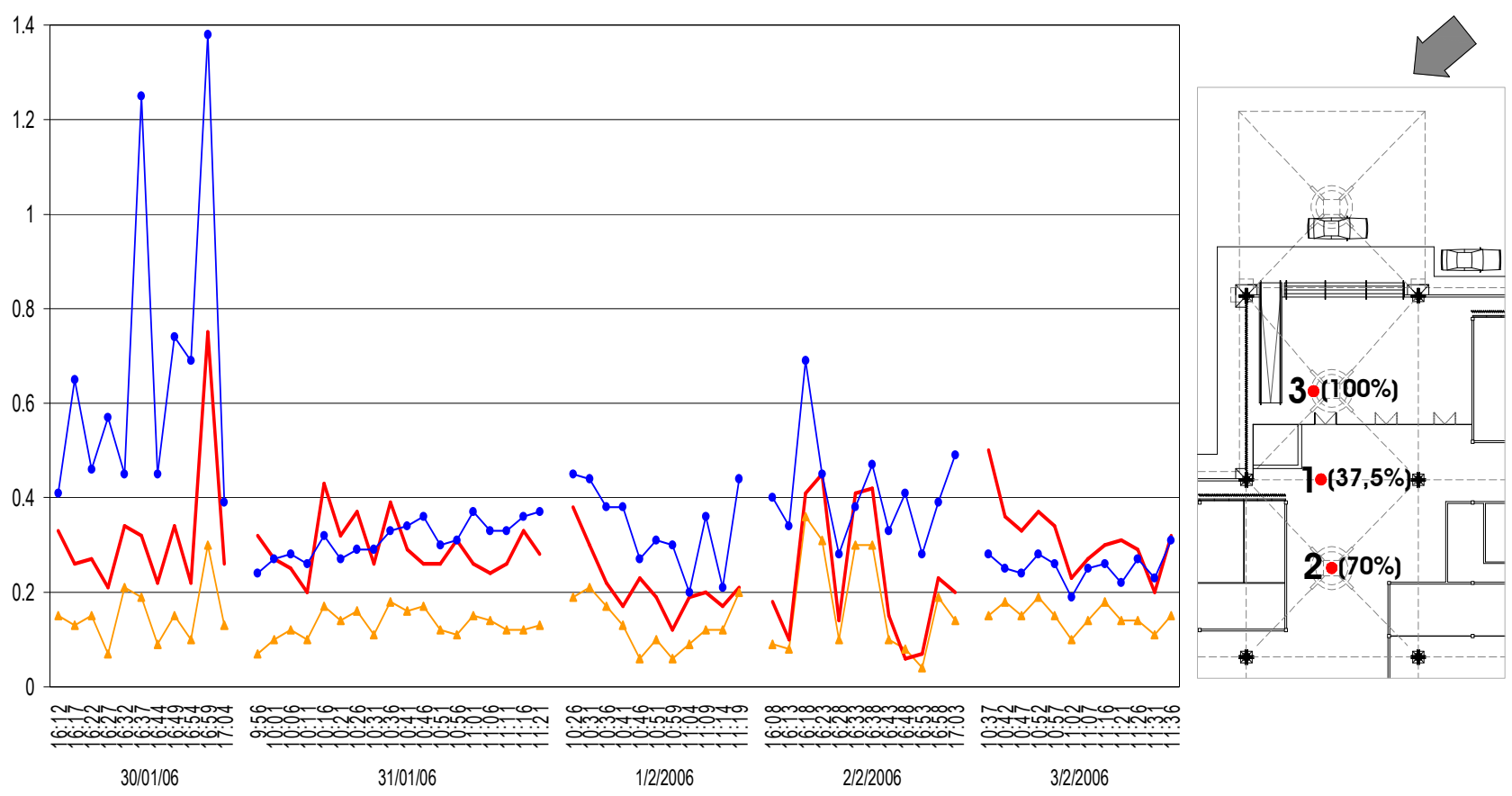

(a)

(b)

$\rightarrow$ Veloc. pto $1(\mathrm{~m} / \mathrm{s}) \longrightarrow$ Veloc. pto $2(\mathrm{~m} / \mathrm{s}) \longrightarrow$ Veloc. pto 3 - externo $(\mathrm{m} / \mathrm{s})$

Gráfico 9.6: (a) Área 1: entrada do edifício - velocidade do ar (m/s); (b) Posicionamento dos anemômetros

$\mathrm{Na}$ área 1, as aberturas para entrada do ar são compostas por: três portas de entrada, onde apenas uma encontrava-se aberta durante as medições (em frente ao ponto 3), a área acima delas e as áreas laterais que não possuem vedação. As áreas de circulação são bastante integradas ao exterior, através de muitas aberturas, o que faz com que a entrada de ar seja generosa (cerca de $50 \mathrm{~m}^{2}$ somente na divisória da entrada). A saída de ar para efeito chaminé, porém, conta com uma área de abertura total de apenas $0,54 \mathrm{~m}^{2}$ por coifa.

As medições no ponto 2, localizado abaixo da abertura de saída do ar para efeito chaminé, indicam um bom aproveitamento do vento externo disponível - $70 \%$, chegando a velocidades superiores à externa, em certos momentos, como pode ser observado no gráfico 9.6. As velocidades do ar neste ponto e no ponto externo, porém, são extremamente baixas e insuficientes para que haja uma boa ventilação natural do edifício. Enquanto a média de vento externa foi de $0,40 \mathrm{~m} / \mathrm{s}$, a média no ponto 2 foi de $0,28 \mathrm{~m} / \mathrm{s}$. A média do ponto 1 foi ainda mais baixa $-0,15 \mathrm{~m} / \mathrm{s}$, com um aproveitamento do vento externo de $37,5 \%$. Apenas em períodos chuvosos, como no dia 30/01, o vento atingiu velocidades mais altas. 
Já na área 2, que liga o edifício principal ao anexo (gráfico 9.7), o ponto 2, localizado abaixo da coifa, apresenta desempenho bastante abaixo da área anterior, com aproveitamento médio de apenas $22 \%$ do vento externo. Isto se deve ao fato das aberturas de entrada do ar estarem, em sua maioria, posicionadas desfavoravelmente em relação à direção dos ventos dominantes locais, o que dificulta a penetração de ar no ambiente. As únicas aberturas que estão favoravelmente posicionadas são as aberturas do jardim que, como já foi visto, não são adequadas para prover ventilação natural. A média do vento externo obtida nesta área foi de $0,41 \mathrm{~m} / \mathrm{s}$ e a média para o ponto 2 foi de $0,09 \mathrm{~m} / \mathrm{s}$. 0 ponto 1 , por estar situado em uma área de corredor, próximo às aberturas do jardim interno, obteve um aproveitamento médio do vento um pouco superior - 46\% - com uma velocidade média de $0,19 \mathrm{~m} / \mathrm{s}$.

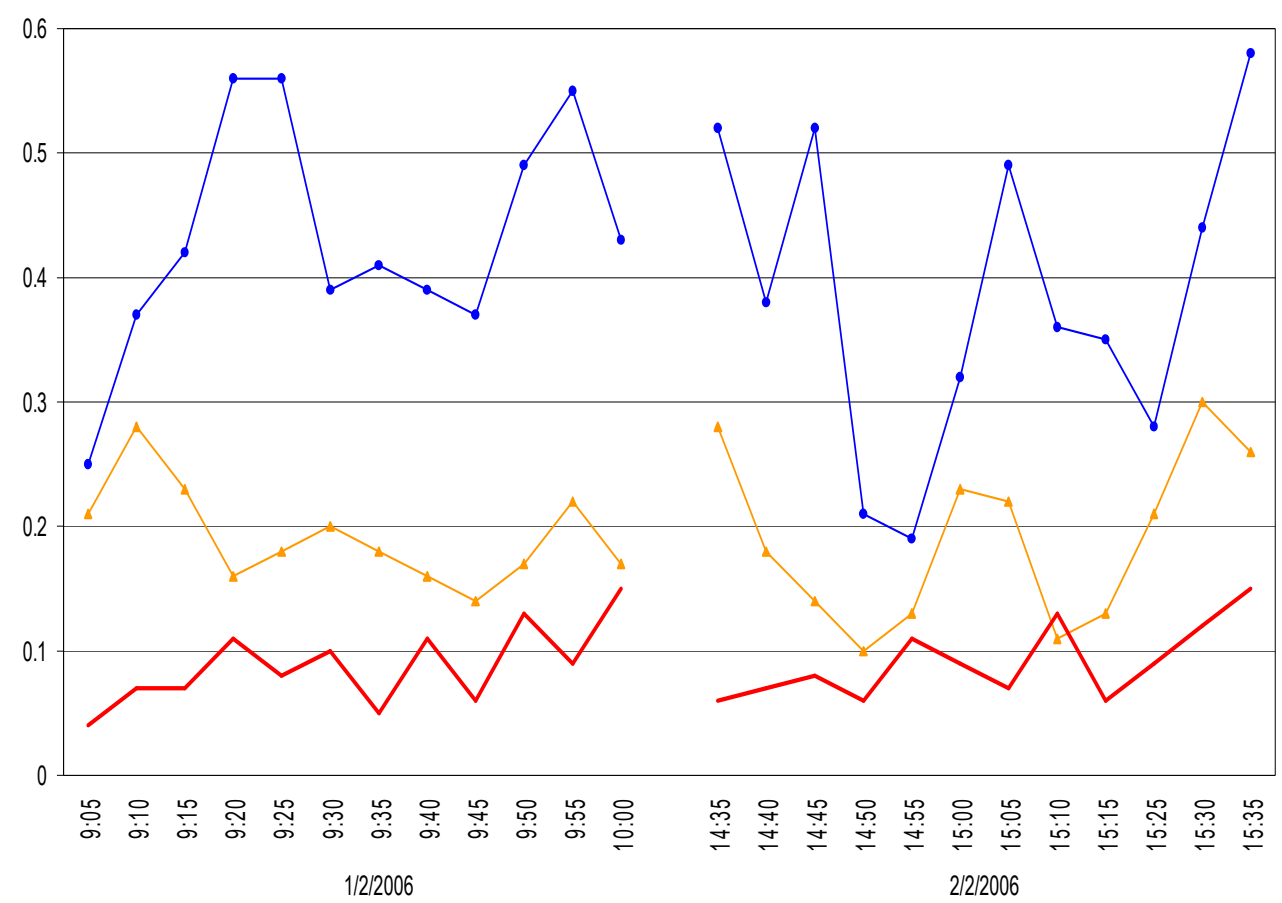

(a)

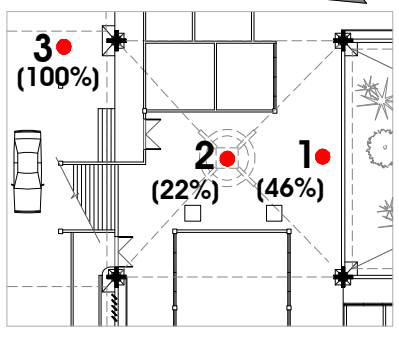

(b)

$\neg$ Veloc. pto $1(\mathrm{~m} / \mathrm{s}) \longrightarrow$ Veloc. pto $2(\mathrm{~m} / \mathrm{s}) \longrightarrow$ Veloc. pto 3 - externo $(\mathrm{m} / \mathrm{s})$

Gráfico 9.7: (a) Área 2: ligação do edifício principal ao anexo - velocidade do ar (m/s); (b)

Posicionamento dos anemômetros

\subsection{ANÁLISE DOS RESULTADOS}

Através do cruzamento dos dados obtidos nas análises qualitativa e quantitativa e das recomendações dadas por Mahoney e pela norma ASHRAE, pode-se agora realizar uma análise de desempenho 
térmico e de ventilação natural do edifício da Suframa.

\subsubsection{Análise de desempenho térmico: temperatura e umidade}

Baseando-se na zona de conforto estabelecida pela ASHRAE Standard 55-2004 para os meses de janeiro e fevereiro - que recomenda um intervalo de temperatura de $22,3^{\circ} \mathrm{C}$ a $29,3^{\circ} \mathrm{C}$ para 0 clima de Manaus, para $80 \%$ de aceitabilidade dos usuários de um espaço - pode-se analisar os resultados obtidos no monitoramento de temperatura interna do edifício da Suframa. Tomando os valores obtidos para média das máximas $-29,2^{\circ} \mathrm{C}$ - e média das mínimas $-26,2^{\circ} \mathrm{C}$ - do ponto interno 1 (entrada principal), observa-se que os valores estão dentro dos limites da norma, e são considerados confortáveis. Apenas no dia 04/02 o valor recomendado para temperatura máxima foi ultrapassado no ambiente interno, no período das $14 \mathrm{~h}$ às $21 \mathrm{~h} 30 \mathrm{~min}$, chegando a $30,71^{\circ} \mathrm{C}$ às $17 \mathrm{~h} 15 \mathrm{~min}$. 0 outro ponto onde foram realizadas medições internas, ponto 4 , obteve resultados parecidos: médias de $29,6^{\circ} \mathrm{C}$ e $26,2^{\circ} \mathrm{C}$, ultrapassando muito pouco a média máxima recomendada.

O acentuado amortecimento da temperatura interna, resultante das características térmicas do material predominante na construção, o concreto armado, permitiu que o ambiente interno permanecesse dentro da zona de conforto, mesmo em dias com temperaturas externas mais elevadas. No dia 01/02, por exemplo, a temperatura externa chegou a $32,76^{\circ} \mathrm{C}$ às $13 \mathrm{~h} 45 \mathrm{~min}$, enquanto o pico máximo de temperatura interna chegou apenas a $29,5^{\circ} \mathrm{C}$, às $14 \mathrm{~h} 15 \mathrm{~min}$. Porém, deve ser levado em consideração que as medições foram realizadas na época menos quente do ano no município, e que na época crítica (meses de julho a outubro) a elevada inércia térmica pode contribuir negativamente.

O monitoramento acusou uma média de temperatura interna $0,5^{\circ} \mathrm{C}$ acima da média externa. Isto significa que o ganho de calor solar resultante do concreto aparente fez com que a média interna ultrapassasse a média externa, isto em um clima onde se deseja perder calor, e não ganhar. Esta diferença pode se ampliar ainda mais nas épocas mais quentes, e tornar o ambiente interno desconfortável por um período prolongado.

A inércia térmica é uma propriedade física que indica como o fluxo térmico atravessa uma parede e é armazenado em seu interior. $O$ valor que ela pode assumir para um determinado ambiente depende de dois fatores: a resistência térmica do revestimento e o "peso" dos componentes que compõem o recinto (ALUCCI, 1981). Sabe-se que o concreto armado é um material pesado, com inércia térmica elevada, e materiais com estas características não são recomendados para construções em clima quente e úmido, por armazenarem grande quantidade de calor e o transmitirem ao ambiente interno. Por isso Mahoney 
indica, para o clima de Manaus, coberturas e paredes leves, de baixa inércia térmica, pois em climas quentes e úmidos, de amplitudes térmicas baixas, é desaconselhável 0 acúmulo de calor. As coberturas devem ser termicamente isoladas e refletir a radiação solar. Sua transmitância térmica não deve ultrapassar $1,1 \mathrm{~W} / \mathrm{m}^{2} \mathrm{C}$ e o fator de calor solar deve ser igual ou inferior a $4 \%$.

Para a cobertura em concreto armado (espessura de $18 \mathrm{~cm}$ ) do edifício da Suframa, a transmitância térmica é de $3,13 \mathrm{~W} / \mathrm{m}^{2} \mathrm{C}$, valor bastante superior ao limite estabelecido por Mahoney. A cobertura é pintada de branco, o que favorece a reflexão da radiação solar, porém o fato da transmitância térmica ser elevada faz com que o fator de calor solar seja de 3,8\%, próximo ao limite máximo. 0 atraso térmico está dentro do recomendado por Mahoney, que é de no máximo 3 horas, mas em alguns dias chegou a ultrapassar este limite. Isto comprova que o concreto armado é um material inadequado para construções em clima quente e úmido. No entanto, este material compõe toda a cobertura (face mais atingida pela radiação solar), estrutura e parte das vedações laterais do edifício da Suframa.

Diferentemente do concreto, a madeira é um material recomendado para construções neste clima, por possuir inércia térmica baixa. Ao comparar os dois materiais, podem ser determinadas outras características do concreto que influenciam negativamente no desempenho térmico do edifício. Por isso, são apresentadas na tabela abaixo as seguintes características físicas destes materiais: condutividade térmica (que está diretamente relacionada à transmitância térmica), densidade e capacidade calorífica.

Tabela 9.2 - Condutividade térmica, densidade e calor específico de materiais ${ }^{26}$

\begin{tabular}{|l|c|c|c|}
\hline \multicolumn{1}{|c|}{ Material } & $\boldsymbol{\lambda}\left(\mathbf{W} / \mathbf{m}^{\circ} \mathbf{C}\right)$ & $\mathbf{d}\left(\mathbf{k g} / \mathbf{m}^{3}\right)$ & $\mathbf{c}\left(\mathbf{J} / \mathbf{K g}^{\circ} \mathbf{C}\right)$ \\
\hline Concreto aparente & 1,65 & 2200 & 1005 \\
\hline Madeira (bétula, pinho Silvestre, pinho marítimo) & 0,15 & 500 & 1424 \\
\hline
\end{tabular}

O coeficiente de condutividade térmica determina as trocas de calor por condução de um material. Os dados obtidos mostram que o concreto apresenta um valor onze vezes maior do que o da madeira, ou seja, conduz onze vezes mais calor. Ao calcular a capacidade térmica para uma parece de $10 \mathrm{~cm}$ de espessura, obtém-se um valor de $221 \mathrm{~kJ} / \mathrm{m}^{2}{ }^{\circ} \mathrm{C}$ para o concreto, e um valor de $71 \mathrm{~kJ} / \mathrm{m}^{2} \mathrm{C}$ para a madeira, o que mostra a maior capacidade do concreto em absorver e armazenar calor. Todos estes fatores são indicativos da inércia térmica elevada do material, e revelam características inadequadas ao clima local.

Ao observar os gráficos 9.1 e 9.3 (item 9.2.2), verifica-se que durante a maior parte do tempo a

26 fonte: FROTA e SCHIFFER, 1995 apud CSTB - Régles de calcule; Gomes, R. J.; PUPPO, E. \& PUPPO, O. 
temperatura interna apresenta valores superiores à externa. Estes valores ocorrem no período da noite, madrugada e manhã, que é quando o calor absorvido e armazenado no período da tarde é retransmitido por convecção e por radiação ao ambiente interno. Este fator, entretanto, pode ser considerado positivo para edificações que são utilizadas apenas durante 0 dia, pois no horário de trabalho as temperaturas internas ficam abaixo da externa. No caso da Suframa, os dados obtidos indicam que no período da tarde, que é o horário mais quente, a temperatura interna está abaixo da externa. Porém deve-se levar em consideração que em alguns outros horários, como no início da manhã ou início da noite, a temperatura interna pode ficar bastante acima da externa.

O uso excessivo de concreto armado neste edifício, principalmente em toda a cobertura, que é a face mais atingida pela radiação solar, mostrou uma escolha contraditória à procura por adequação bioclimática ao sítio de intervenção, característica marcante na obra de Severiano Porto e perseguida em grande parte de seus projetos. Uma forte intenção deste projeto de cobertura, elaborado com este material, era de proporcionar ventilação por efeito chaminé. A análise da real eficácia desta solução encontra-se no item a seguir.

\subsubsection{Análise de ventilação natural}

Sabe-se que, para a ocorrência de ventilação por efeito chaminé, dois fatores primordiais são a diferença de altura entre as aberturas de entrada e saída do ar e o tamanho das aberturas. No caso da Suframa, o pé-direito elevado $(8,70 \mathrm{~m})$ contribui para que haja um bom gradiente de temperatura, favorável à ventilação, como pôde ser observado nas medições de temperatura a diferentes alturas, apresentadas no gráfico 9.5 (item 9.2.2). Porém, o grande problema deste edifício está na abertura de saída do ar, que é insuficiente para a criação de uma zona de sucção que resulte em um fluxo de ar vertical. Os resultados obtidos na análise qualitativa mostram que o projeto de ventilação por efeito chaminé apresenta erros, e a pesquisa de campo realizada comprova que realmente não há um fluxo de ar ascendente.

No monitoramento realizado na área 1 (gráfico 9.6, item 9.2.3) houve um aproveitamento maior do vento no ponto 2, situado na direção da abertura de saída do ar. Este fluxo, porém, não se deve a um efeito de sucção que poderia ser provocado pela abertura zenital, mas sim ao efeito de estrangulamento causado pelas vedações laterais dos ambientes fechados, que neste ponto se aproximam. Já que a área para passagem do ar é menor, a velocidade do vento aumenta, para manter a mesma vazão. Isto pôde ser comprovado pela verificação da direção do vento, feita durante as 
medições, que acusou um fluxo de ar horizontal. Na área 2 (gráfico 9.7, item 9.2.3), o ponto de medição situado abaixo da abertura de saída do ar (ponto 2) foi o que apresentou as menores velocidades de ar, o que mostra a inexistência de fluxo de ar ascendente.

Faltam, portanto, aberturas de saída maiores para o real funcionamento do efeito chaminé. Para este tipo de ventilação, a área de saída do ar deve ser um pouco maior do que a de entrada - o chamado 'efeito Venturi', que provoca um aumento na velocidade do ar. O que ocorre neste edifício, entretanto, é exatamente 0 contrário: há aberturas generosas para entrada do ar nas áreas de circulação, mas a saída praticamente inexiste.

A velocidade média de ar interna obtida no monitoramento variou de $0,10 \mathrm{~m} / \mathrm{s}$ - o que não provoca nenhum efeito de esfriamento sobre o homem - a $0,25 \mathrm{~m} / \mathrm{s}$ - que provoca efeito de esfriamento de cerca de $0,7^{\circ} \mathrm{C}$ (Borel, 1967). Estas velocidades são consideradas imperceptíveis ao homem, segundo Olgyay (1998) e Evans (1957 apud FREIXANET; VIQUEIRA, 2004). Como os ventos locais já são muito fracos (os valores obtidos foram de aproximadamente $0,4 \mathrm{~m} / \mathrm{s}$ ), a única maneira de prover ventilação natural seria realmente através do efeito chaminé, que poderia originar fluxos de ar pela diferença de temperatura. Porém a estratégia, que seria ideal para o projeto, foi trabalhada de forma incorreta, o que fez com que a cobertura em forma de coifa perdesse a função para a qual foi destinada originalmente, tornando-se uma solução meramente formal. Tanto que, no projeto de reforma, todos os ambientes fechados abaixo das coifas foram cobertos com laje de concreto e foram instalados aparelhos de refrigeração artificial.

Estes ambientes possuem aberturas nas laterais opostas, visando proporcionar ventilação cruzada, como alternativa ao uso de ar condicionado. Não foi possível realizar medições de ventilação nestes espaços, devido ao uso constante do ar condicionado. Porém, somente pela análise qualitativa já foi possivel notar que a estratégia não funciona apropriadamente, pois os brises móveis presentes nas fachadas externas constituem uma barreira ao fluxo de ar natural; principalmente pelo fato de ficarem fechados, para reduzir a excessiva luminosidade natural incidente no ambiente interno. Além disso, as esquadrias do tipo máximo-ar também constituem um elemento desfavorável à ventilação. Alguns tipos de esquadrias têm grandes limitações em seu desempenho quanto à ventilação natural, e isto deve ser sempre bem estudado para que se utilize adequadamente em cada situação particular.

\subsubsection{Considerações finais}

As análises de desempenho térmico e ventilação natural empreendidas na Suframa mostram que o 
edifício não é adequado às características climáticas da região e não foram aplicados conceitos bioclimáticos básicos, presentes no discurso do arquiteto, como o uso de materiais apropriados ao clima, por exemplo. Baseando-se na idéia de criar uma imagem de maior solidez ao órgão, Porto utiliza o concreto armado em toda a estrutura e cobertura do edifício. Este argumento torna-se insuficiente, entretanto, frente a todos os problemas trazidos por esta escolha.

Ao analisar o projeto de acordo com os parâmetros estabelecidos por Mahoney, pode-se notar que diversas estratégias encontradas contrariam as suas recomendações. Além do material predominante utilizado, o concreto armado, não ser recomendado ao clima local devido à inércia térmica elevada, alguns outros fatores merecem ser destacados. A edificação, antes da reforma, não era adequadamente protegida da chuva, que penetrava no ambiente interno através das aberturas zenitais e dos jardins; por isso o domo da coifa foi rebaixado, reduzindo o tamanho da abertura de saída do ar (que já era insuficiente) e barrando totalmente a ventilação por efeito chaminé. $O$ fechamento lateral dos jardins também reduziu a circulação interna do ar.

Há aberturas em todas as fachadas, inclusive nas de orientação Leste e Oeste, e não há beirais adequados para proteção contra a incidência direta de radiação solar. Para amenizar o problema, foram instalados, no projeto de reforma, brises verticais móveis do lado externo de todas as fachadas, que hoje em dia funcionam como uma barreira ao vento nas aberturas laterais.

Tudo isto contribui para o mau desempenho térmico da edificação e faz com que o ar condicionado seja utilizado em período integral, já que há tantos fatores desfavoráveis à climatização natural. Vale ressaltar que o funcionamento das estratégias de ventilação natural propostas por Severiano depende de detalhes projetuais que poderiam ser solucionados, na etapa de projeto, pelo auxílio de uma consultoria especializada. As idéias apresentadas são de grande valor, e não se encontram na maioria da arquitetura produzida na época. No caso do efeito chaminé, o correto dimensionamento das aberturas é fator essencial para seu bom funcionamento.

Também é importante citar aqui um fato já discutido no capítulo anterior: o uso excessivo e muitas vezes desnecessário de sistemas de refrigeração artificial em cidades de clima quente, como Manaus. O monitoramento realizado no edifício da Suframa apontou temperaturas dentro da zona de conforto estabelecida pela ASHRAE na maior parte do tempo, já que a pesquisa foi feita no período menos quente do ano. Entretanto, todos os ambientes fechados do prédio estavam com os aparelhos de ar condicionado funcionando. À medida que os usuários de um edifício se acostumam com 0 ar condicionado, a tolerância à variação de temperatura diminui, o que significa uma menor aceitação de estratégias de climatização natural como recursos para obtenção de conforto térmico. 


\section{ALDEIAS INFANTIS SOS BRASIL, 1994}

Esta obra foi uma das últimas construídas por Severiano Porto em Manaus, alguns anos antes de seu retorno ao Rio de Janeiro. Das três obras selecionadas para análise, esta é a menos conhecida e divulgada em publicações especializadas. Apesar de não estar entre as obras consideradas de maior importância na carreira do arquiteto, sua escolha se deve ao cuidado no trabalho com a ventilação natural, através do grande refinamento no projeto de esquadrias, visando o melhor proveito possível dos ventos dominantes locais para ventilação natural. É a única das três obras analisadas que até hoje funciona sem aparelhos de refrigeração artificial, fato relevante para a análise empreendida.

\subsection{ANÁLISE QUALITATIVA E DESCRITIVA}

As Aldeias Infantis SOS Brasil fazem parte de uma entidade internacional sem fins lucrativos, fundada no ano de 1949 pelo educador austríaco Hermann Gmeiner. Foram criadas com o objetivo de dar oportunidade a crianças órfãs de viver e crescer em um ambiente familiar, através da formação de pequenas comunidades, as aldeias, compostas por 10 a 12 residências denominadas 'casas-lares'. Cada casa é coordenada por uma mãe-social, que cuida de sete a nove crianças. Hoje presentes em 131 países, as Aldeias Infantis SOS existem no Brasil desde 1967, e desenvolvem suas atividades em

10 Estados através de 14 Aldeias e 12 Centros Sociais que atendem cerca de oito mil crianças e jovens ${ }^{27}$.

Severiano Porto foi convidado a realizar o projeto para as Aldeias SOS do Amazonas em 1994, e sua inauguração se deu em 28 de outubro de 1997. O conjunto é composto por 10 casas-lares, e atende a 102 crianças. O programa das aldeias incentiva que as crianças convivam em um ambiente harmonioso e participem ao máximo da sociedade em que se inserem. Por isso, Porto procurou, como partido arquitetônico inicial, integrar o conjunto ao meio natural e ao contexto urbano local, como forma de melhor integrar também as crianças ao meio, dando-lhes conforto e bem estar para seu crescimento e sua boa educação. A integração das casas-lares aos espaços de uso comum, que também podem ser utilizados pelas comunidades vizinhas, dá forma ao conceito de aldeia presente na concepção do projeto social (ROVO e OLIVEIRA, 2004). O resultado é um conjunto bem estruturado, que traz conforto e qualidade de vida às pessoas que nele habitam.

27 Informações obtidas no site <www.aldeiasinfantis.org.br>. Acessado em: 05 de janeiro de 2006. 


\subsection{1 Área de inserção e implantação}

O terreno destinado à construção da Aldeia SOS do Amazonas possui média declividade e dimensões de $400,7 \mathrm{~m}$ por $164,1 \mathrm{~m}$. O projeto ocupa uma área total de $6.431,22 \mathrm{~m}^{2}$ (LEE, 1998). Está inserido em um bairro de uso predominantemente residencial, onde se encontram construções de pequeno a médio portes.

A implantação geral procurou seguir as curvas de nível do terreno, alterando minimamente seu perfil original. Quanto ao zoneamento, a implantação ocorreu de acordo com o grau de privacidade requerido pelo programa de cada edificação. Edifícios que são abertos para o uso da comunidade são situados na periferia do terreno, próximos às vias de circulação principais, facilitando o acesso e integrando melhor o conjunto ao entorno. Já as casas-lares estão implantadas mais afastadas, pois requerem maior isolamento.

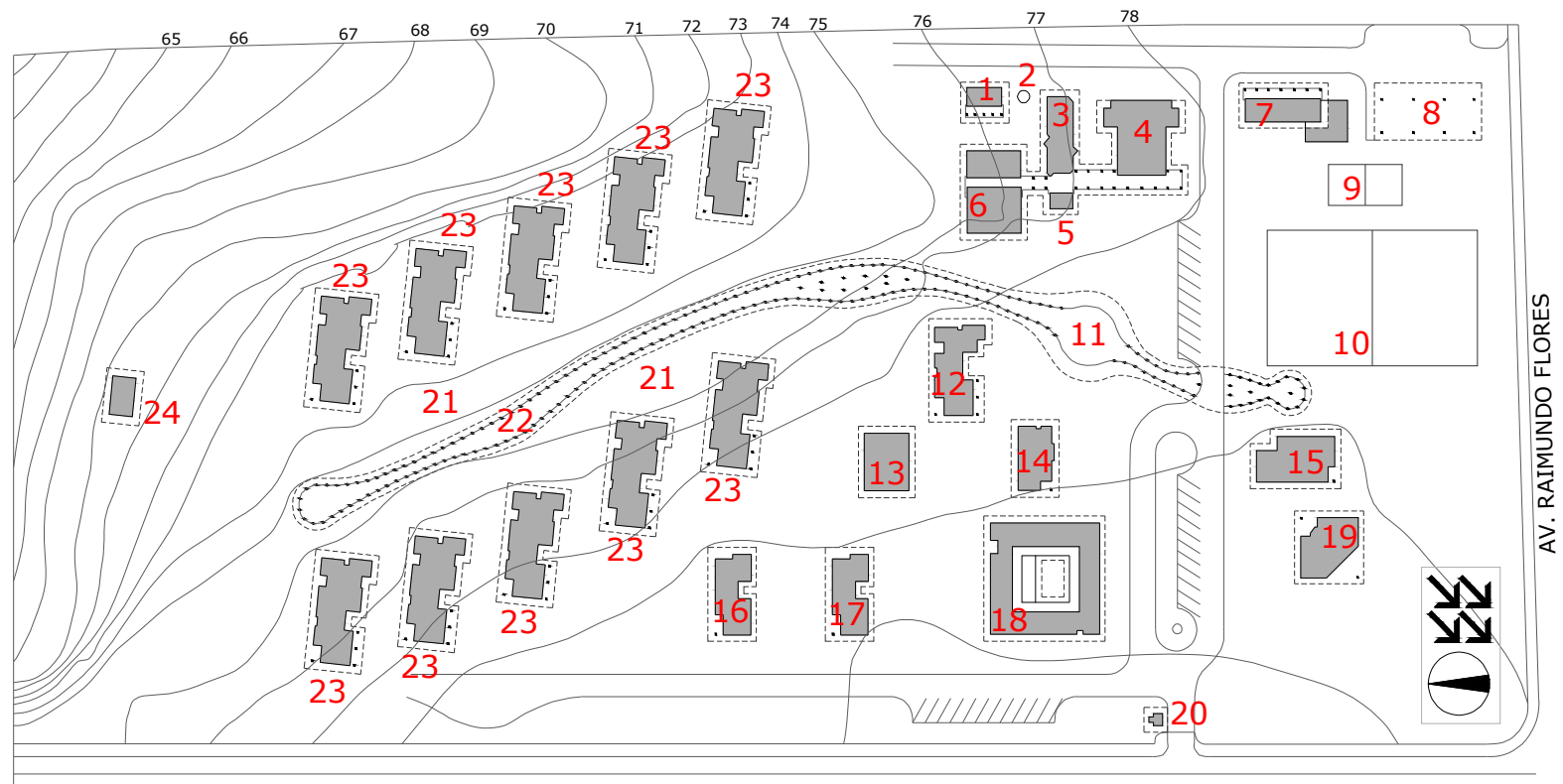

AV. PENETRAÇÃO NORTE-SUL

\section{LEGENDA:}

1- vestiários educação física

2- castelo d'água

3- refeitório

4- auditório

5- sanitários

6- criação e arte

7- lavanderia/ oficinas

8- garagem

\section{9- vôlei}

10- futebol

11- chapéu de palha

12- casa das tias

13- escola de mães

14- alojamento de visitantes

15- biblioteca infantil/ atividades de ensino

16- casa dos dirigentes

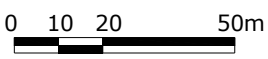

Figura 10.1: Implantação

17- casa do zelador

18- casa comunitária/ depto. médico/ biblioteca

19- jardim de infância

20- guarita

21- playground

22- circulação

23- casa-lar

24- trabalho com terra 

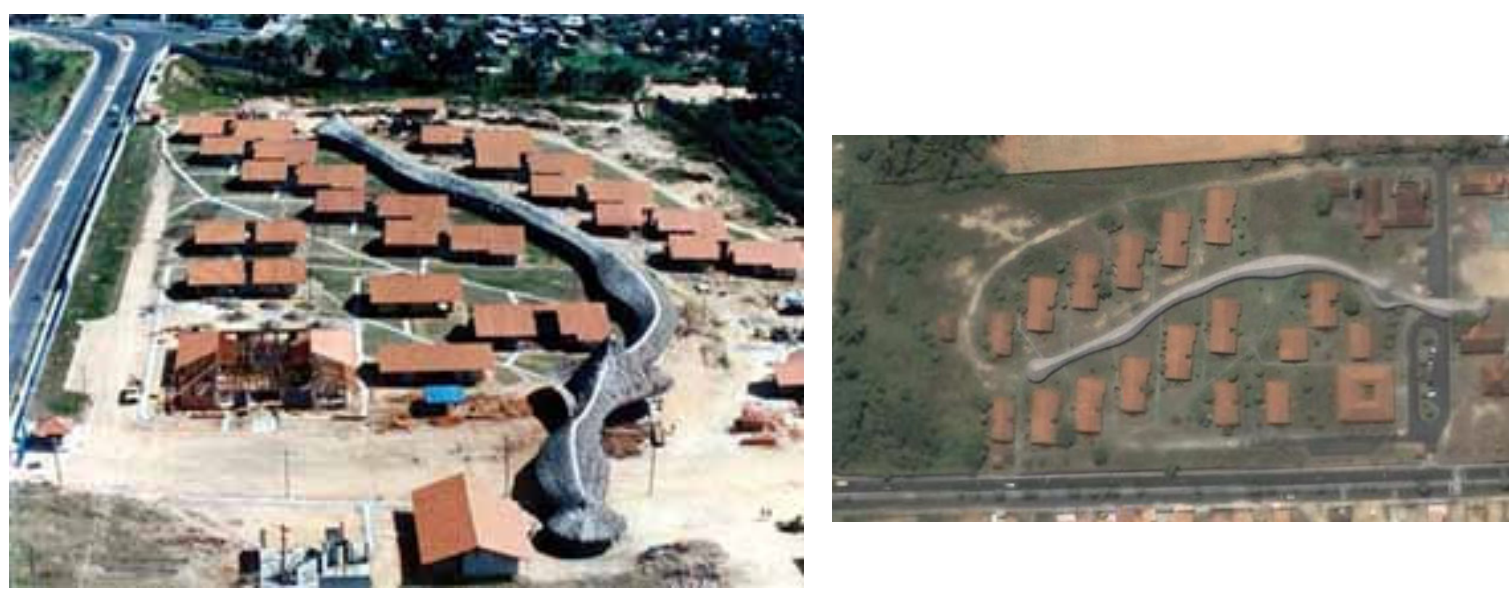

Figuras 10.2 e 10.3: Vista aérea da Aldeia SOS do Amazonas, em fase final de construção e atualmente (arquivo pessoal de Severiano Porto em ROVO e OLIVEIRA, 2004; Google Earth)

\subsubsection{Os edifícios}

O conjunto de edificações da aldeia é formado por: 10 casas-lares, casa das tias, escola de mães, alojamento de visitantes, casa dos dirigentes, casa do zelador, casa comunitária (que funciona como centro administrativo da aldeia), departamento médico, biblioteca, biblioteca infantil, jardim de infância, pavilhão de criação e arte, auditório, refeitório, lavanderia, oficinas, garagem, castelo d'água, trabalho com terra, quadras e vestiários para educação física, playground e chapéu de palha.

O chapéu de palha é o elemento de ligação de todo o projeto. Cria uma circulação sinuosa que integra todas as casas-lares e algumas edificações da aldeia a um espaço único e comum, formando uma espécie de rua-praça. Constitui uma clara referência à cultura regional, pelo sistema construtivo e materiais utilizados, e também por sua tipologia e plasticidade, o que mostra a preocupação do arquiteto em manter e transmitir tal cultura às novas gerações.

A criação de áreas cobertas semelhantes ao chapéu de palha é uma solução recorrente nas obras de Porto: foi utilizada pela primeira vez no restaurante Chapéu de Palha, e posteriormente no consagrado edifício do Centro de Proteção Ambiental de Balbina. Assim como em Balbina, a cobertura sinuosa que atravessa todo o conjunto possui momentos de simples circulação e momentos em que forma espaços de estar, onde o pé-direito se eleva e o espaço coberto se alarga, permitindo assim a realização de diversas atividades. A cobertura da Universidade, apesar de apresentar forma e sistema construtivo completamente diversos a esta, também possui semelhanças no modo como se desenvolve, ora sendo 
apenas circulação ora constituindo espaços de convívio, e no fato de funcionar como elemento integrador dos diversos edifícios.
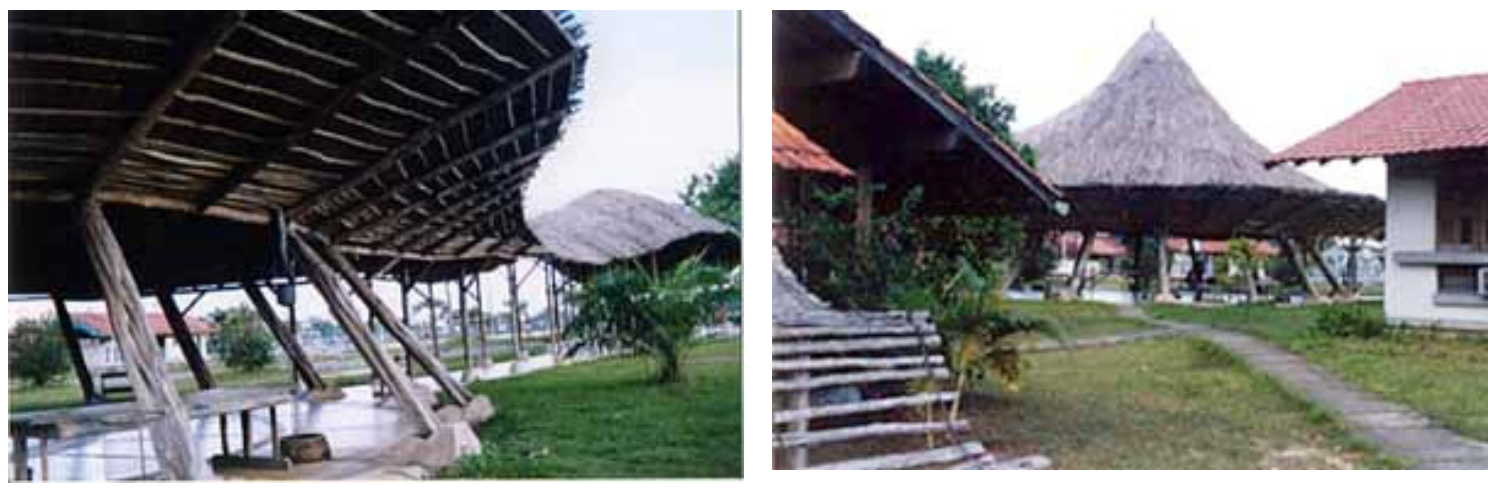

Figuras 10.4 e 10.5: Vista da circulação e chapéu de palha (ROVO e OLIVEIRA, 2004)

A casa-lar, habitação destinada à mãe-social e suas crianças, será o edifício analisado mais detalhadamente, quanto a aspectos bioclimáticos. São dez casas no total, com implantação lindeira à circulação do chapéu de palha, cinco a Leste e cinco a Oeste. Internamente, a distribuição dos espaços se dá por dois patamares distintos: a área social e de serviços ocorre no nível mais elevado, e a área íntima ocorre em um nível um pouco abaixo. Cada casa possui um desnível diferente, de acordo com a topografia do terreno. A separação é feita por uma escada e um jardim interno, que está próximo à porta de entrada e se abre para a sala. A edificação possui varandas e aberturas generosas, que a integram à área externa.

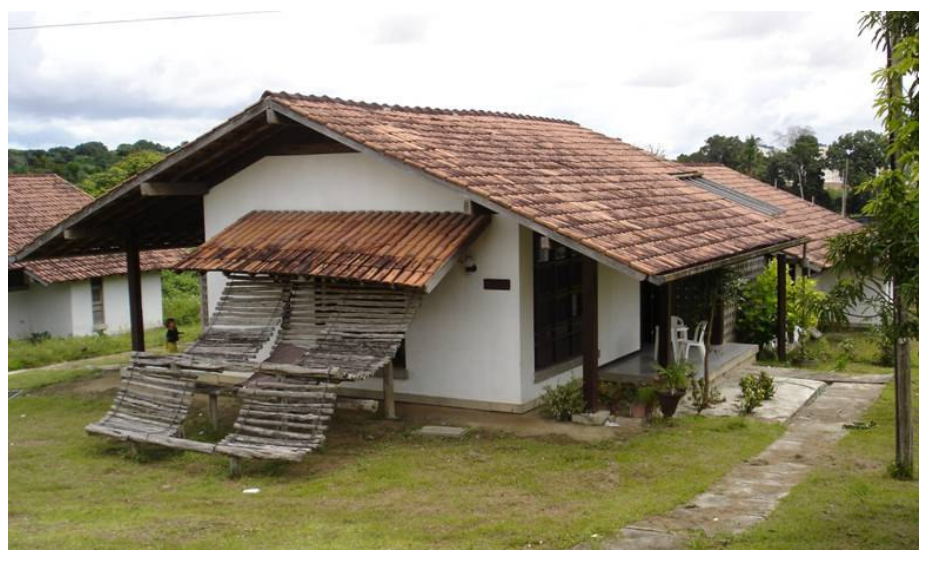

Figura 10.6: Vista da casa-lar 


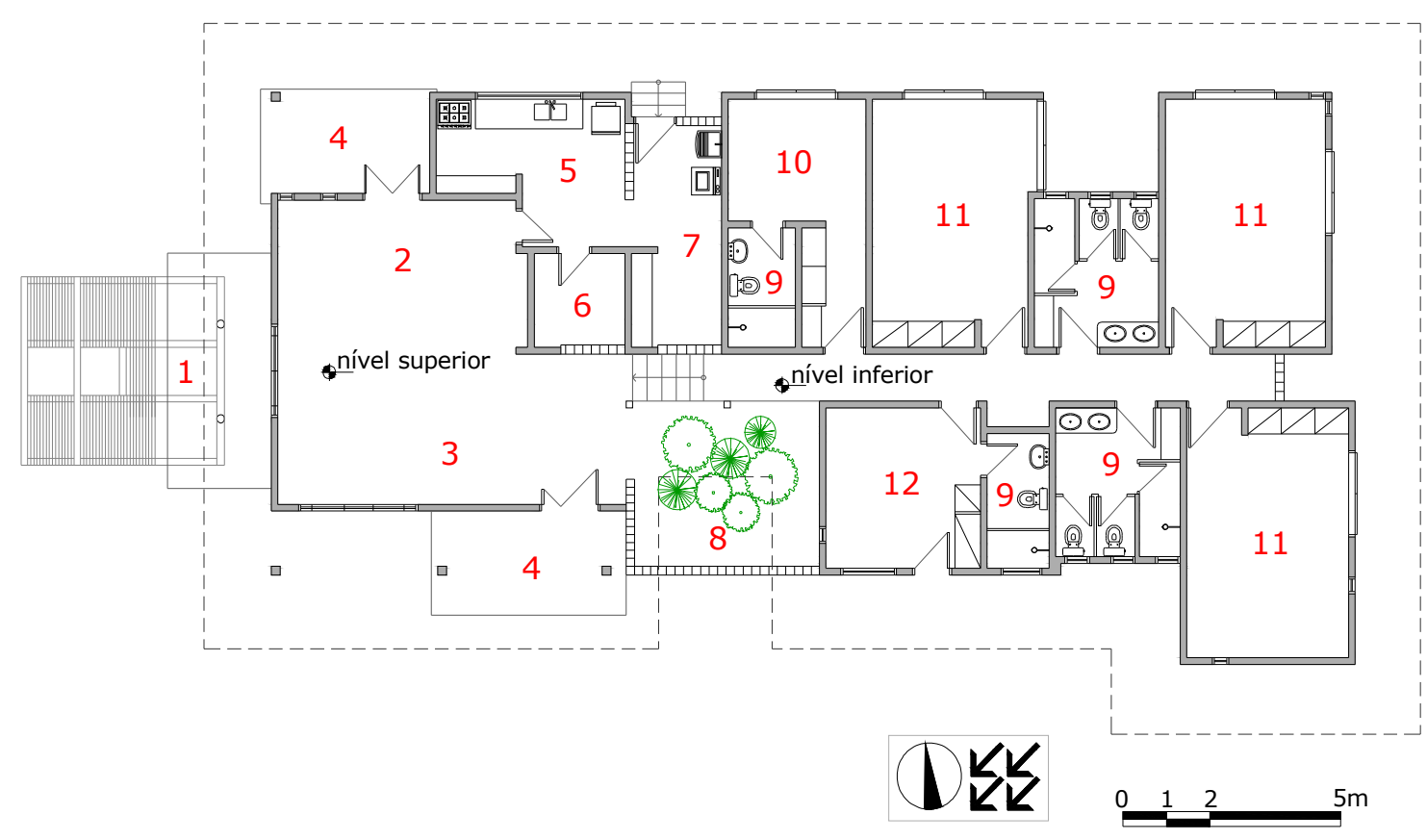

\section{LEGENDA:}

1- pergolado

2- sala de jantar

3- sala de estar

\begin{abstract}
4- varanda
5- cozinha

6- despensa
\end{abstract}

7- área de serviço

8- jardim interno

9- banheiro
10- quarto da mãe 11- quarto das crianças 12- quarto das tias

Figura 10.7: Planta - casa-lar

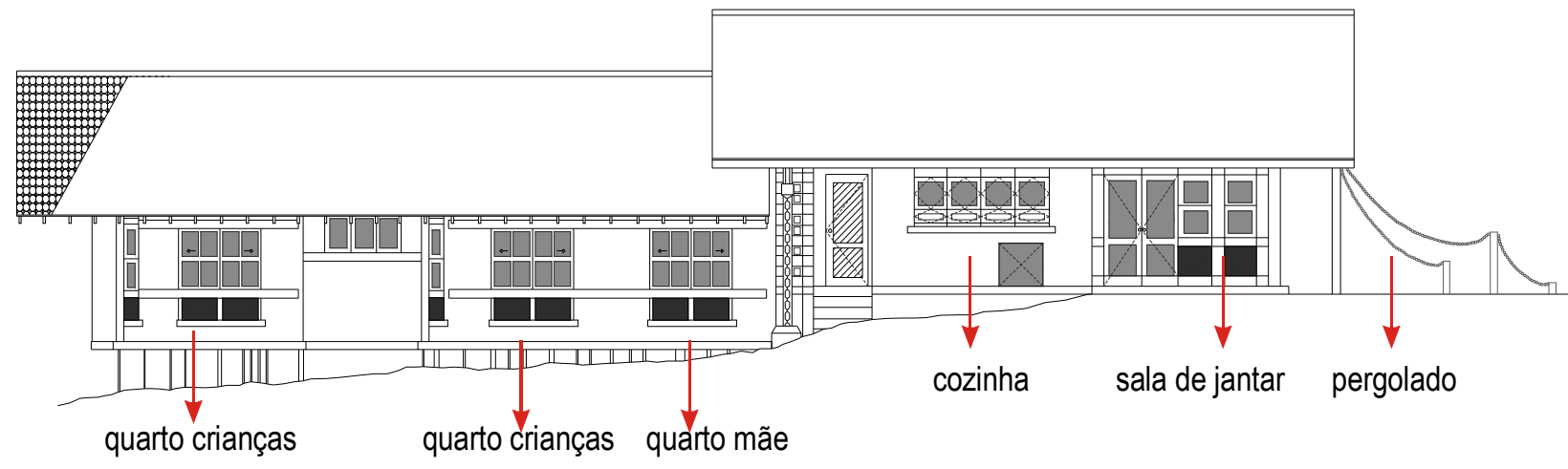

Figura 10.8: Fachada Norte 


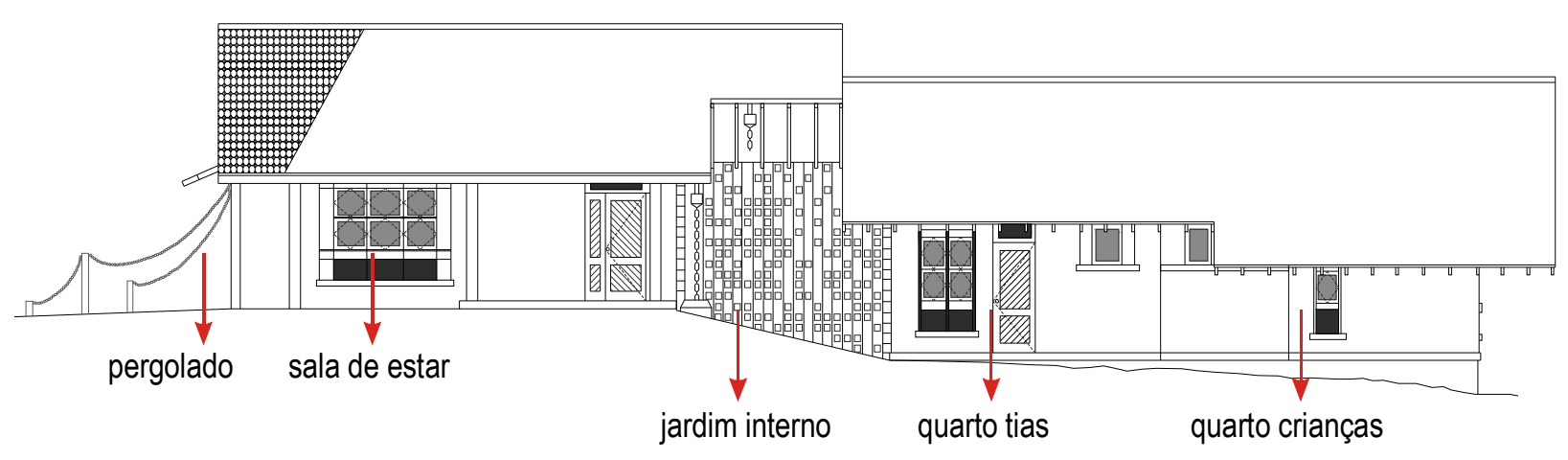

Figura 10.9: Fachada Sul

\subsubsection{Sistema construtivo e materiais}

Os principais materiais utilizados na construção das edificações são alvenaria nas vedações; madeira nas esquadrias, forro e estrutura do telhado; e telha cerâmica na cobertura. A circulação e o chapéu de palha são em madeira, cobertos com folhas de palmeira.

\subsubsection{Estratégias bioclimáticas e conforto ambiental}

A implantação do conjunto de acordo com a configuração natural do terreno permite maior aproveitamento dos ventos dominantes da região. A orientação das edificações é adequada em relação à trajetória do sol, já que as menores faces estão voltadas para Leste e Oeste, orientações mais castigadas pela incidência solar, e as maiores estão voltadas para Norte e Sul, recebendo menos radiação solar direta, de acordo com as recomendações de implantação dadas por Mahoney. As casaslares também seguem este padrão de orientação, com suas menores faces voltadas para Leste-Oeste, o que reduz a incidência de radiação solar sobre a edificação. Também contribui neste intuito o beiral generoso, que a protege da radiação solar e das chuvas. Os desenhos de projeção da sombra do telhado mostram as áreas protegidas em duas épocas distintas do ano: solstício de verão e de inverno, que se apresentam a seguir: 


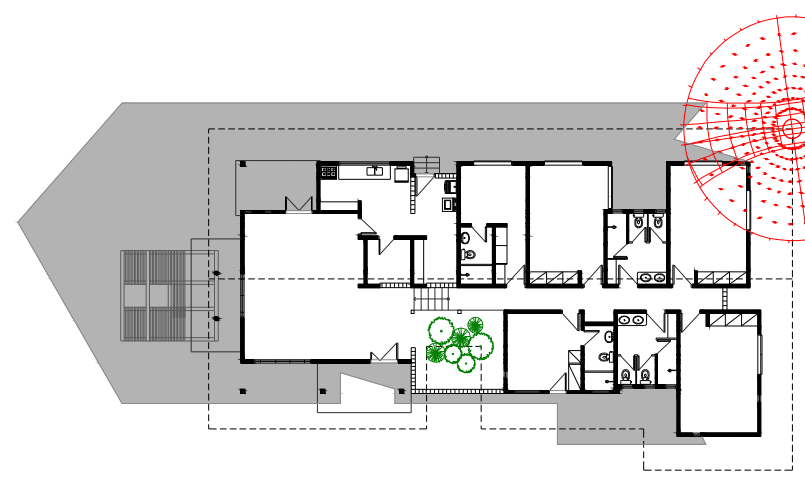

solstício de verão - 8 horas

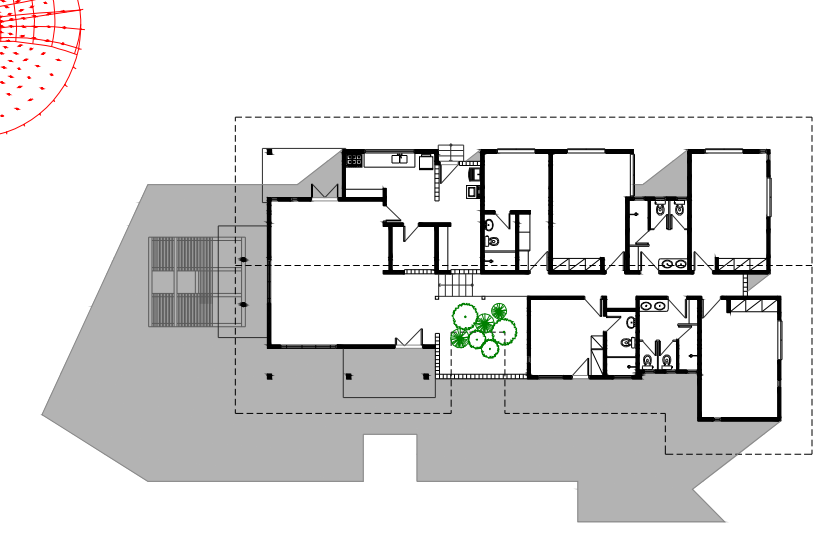

solstício de inverno - 8 horas

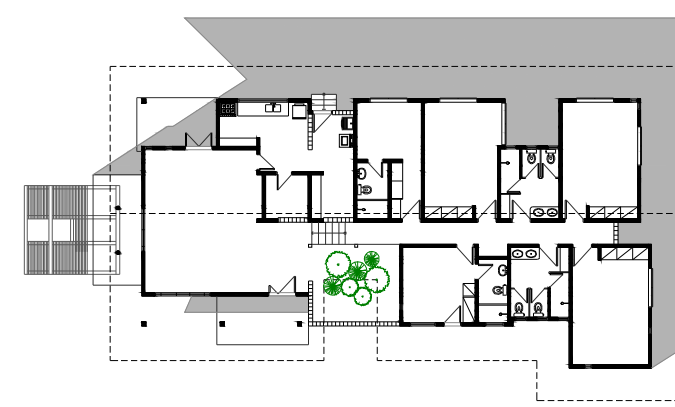

solstício de verão - 16 horas

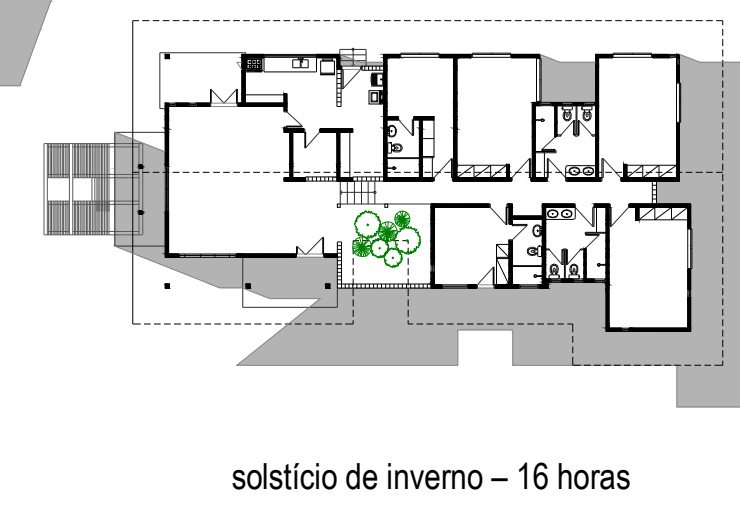

Figura 10.10: Projeção da sombra da cobertura em duas épocas distintas do ano, para a casa-lar

A face Oeste, que é mais castigada pelo sol da tarde, possui um pergolado de madeira que protege a abertura e cria um espaço de estar. É um elemento visual forte que, além de marcar a plasticidade do conjunto, funciona como dispositivo de proteção solar e agrega um espaço sombreado interligado à residência. Tudo isto surge da simples necessidade de um elemento de proteção para a abertura localizada na fachada Oeste, o que demonstra a habilidade de Porto em propor soluções que atendam às exigências do clima e contexto locais e ao mesmo tempo apresentem uma bela forma de apropriação do espaço (figuras 10.11 a 10.13). 


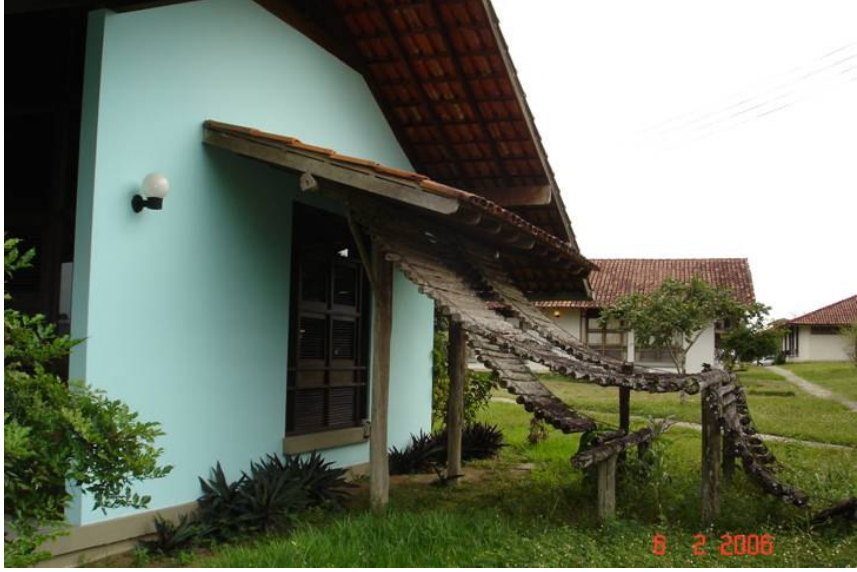

Figura 10.11: Fachada Oeste da casa-lar, com pergolado em madeira

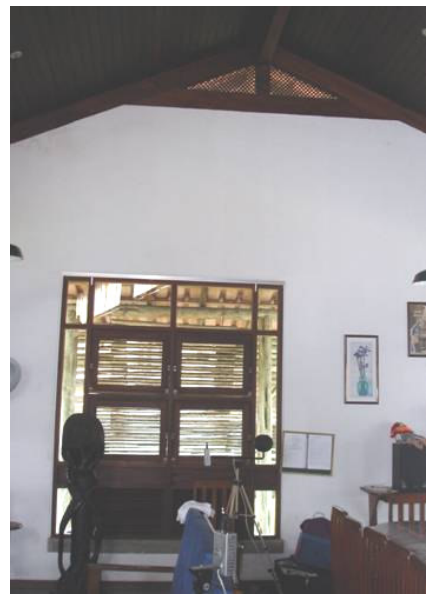

Figura 10.12: Vista interna da abertura protegida pelo pergolado

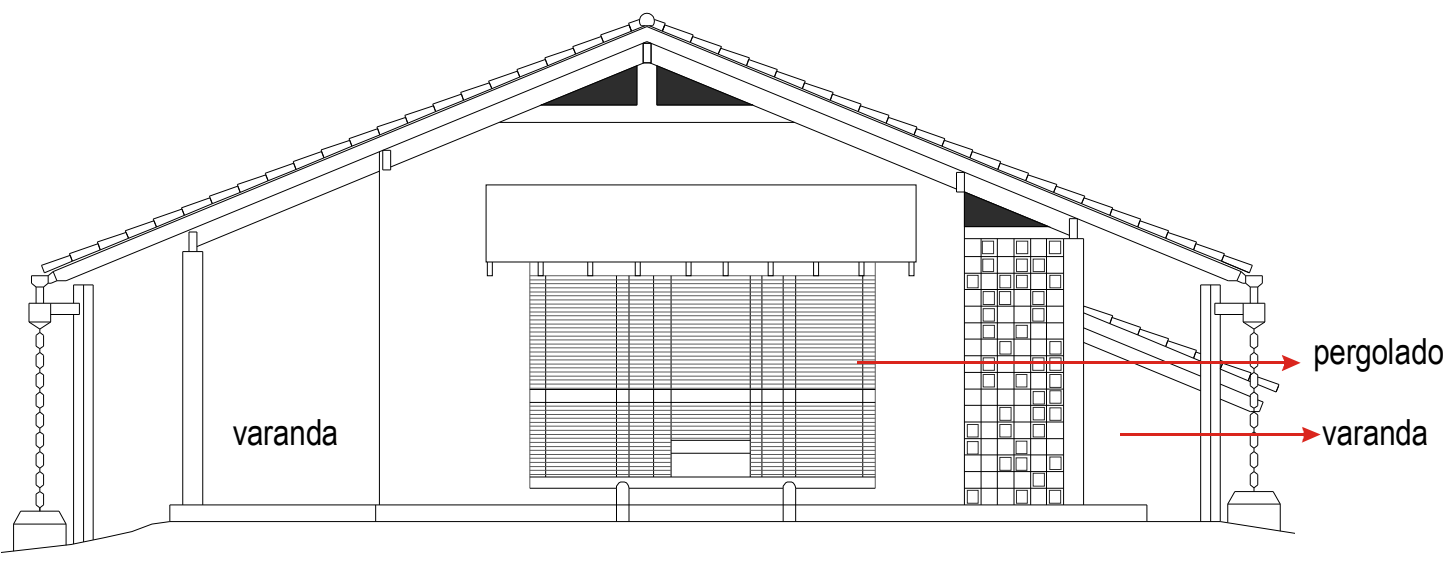

Figura 10.13: Fachada Oeste

As varandas são elementos marcantes no projeto da casa-lar. Elas são definidas pela projeção da cobertura nas fachadas Norte e Sul, protegendo os acessos da casa e configurando uma extensão da área de convivio. Além disso, são uma proteção a mais contra os rigores do clima local - a radiação solar e as chuvas - solução fortemente recomendada para o clima e muito utilizada por Porto em seus projetos para residências. Também está presente nos projetos da residência do arquiteto e da residência Robert Schuster (ver itens 5.3.2 e 5.3.4).

A cobertura do chapéu de palha traz ao conjunto um espaço de estar de uso comum protegido do sol e bastante arejado, já que sua forma de "pirâmide" e seu pé-direito alto permitem fluxo de ar constante, como pode ser observado na figura 10.14. Falta, porém, uma saída de ar quente pela cobertura, para possibilitar a ocorrência de ventilação por efeito chaminé. 


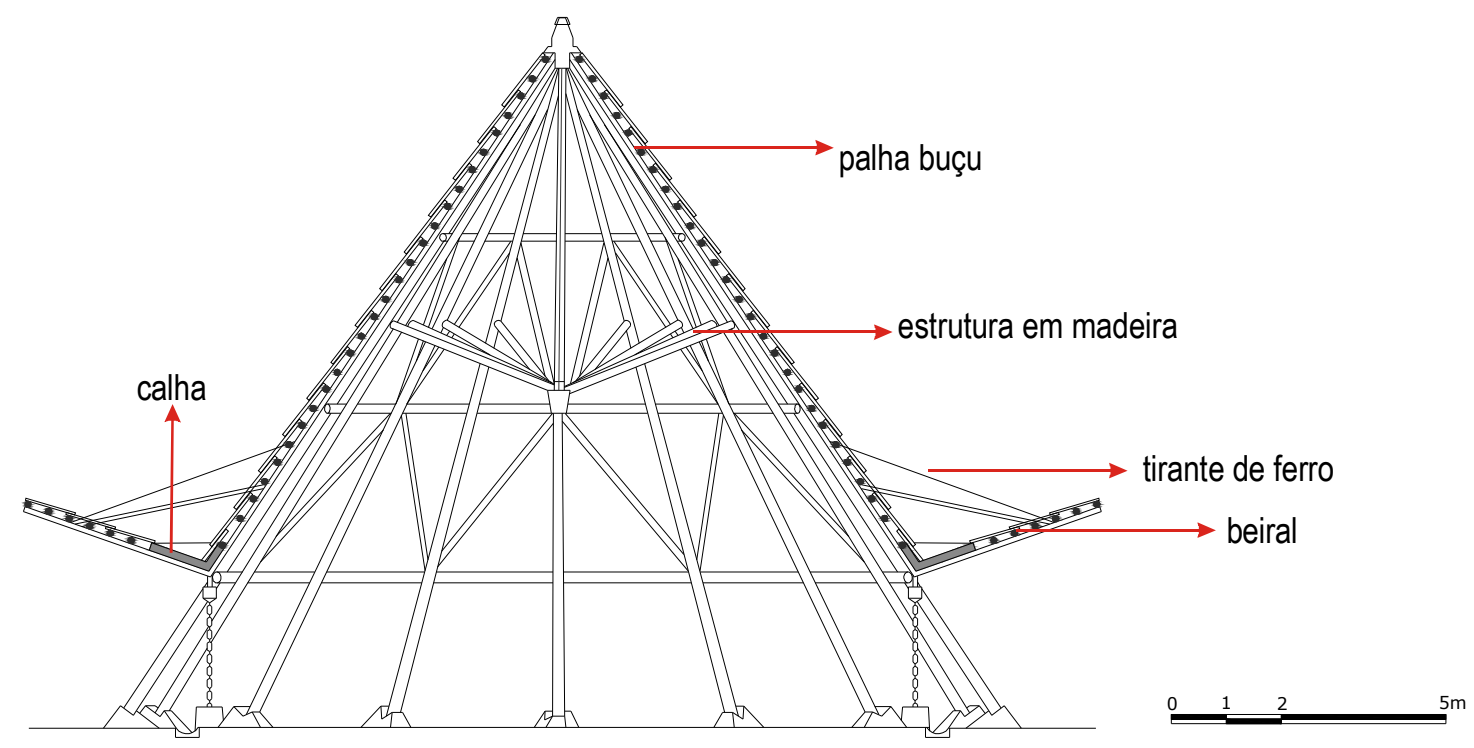

Figura 10.14: Corte do chapéu de palha

\subsubsection{Ventilação natural}

A implantação seguindo as curvas de nível do terreno faz com que cada edifício esteja em uma cota diferente do outro, o que facilita com que o vento percorra todas as edificações. As casas-lares foram corretamente dispostas em fileiras (arranjo em grelha), já que os ventos dominantes Nordeste incidem obliquamente e assim podem atingir todas as edificações, como afirma Olgyay (1998), em experimentos realizados com túnel de vento. A distância entre as casas também permite um bom fluxo de ar entre elas, sem que se perca a relação de vizinhança desejada para a aldeia.

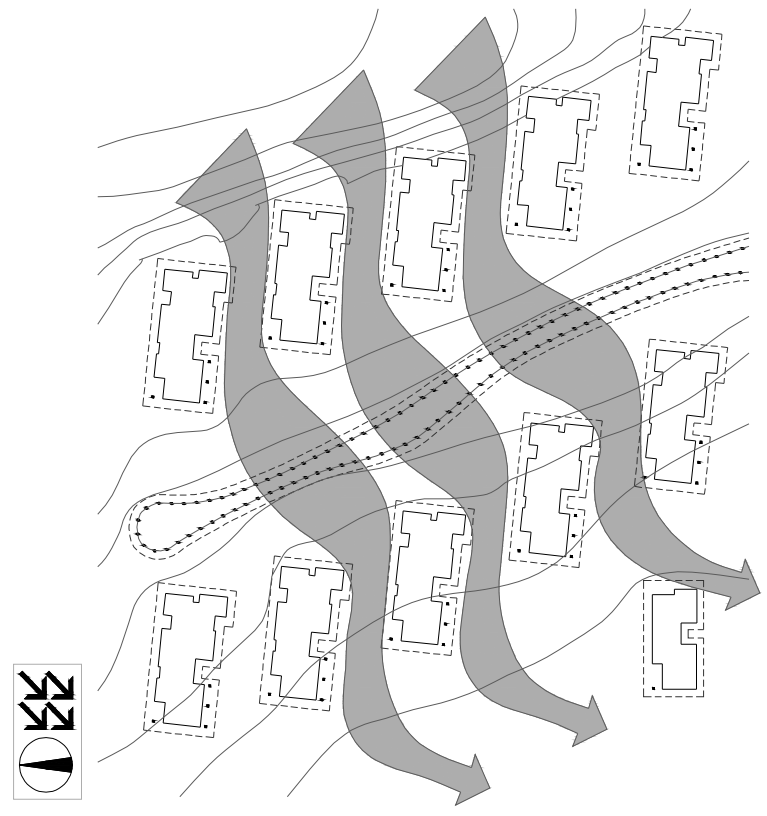

Figura 10.15: Esquema do fluxo de ar ao redor dos edifícios (Adaptado de ROVO e OLIVEIRA, 2004) 
A implantação das casas-lares ligeiramente na diagonal em relação aos ventos dominantes favorece uma melhor distribuição interna do fluxo de ar. Isto ocorre pois quando o vento entra obliquamente a velocidade é mais baixa, porém atinge um volume interno maior, devido às zonas de recirculação criadas, o que proporciona uma ventilação mais satisfatória do ambiente como um todo (GIVONI, 1976).

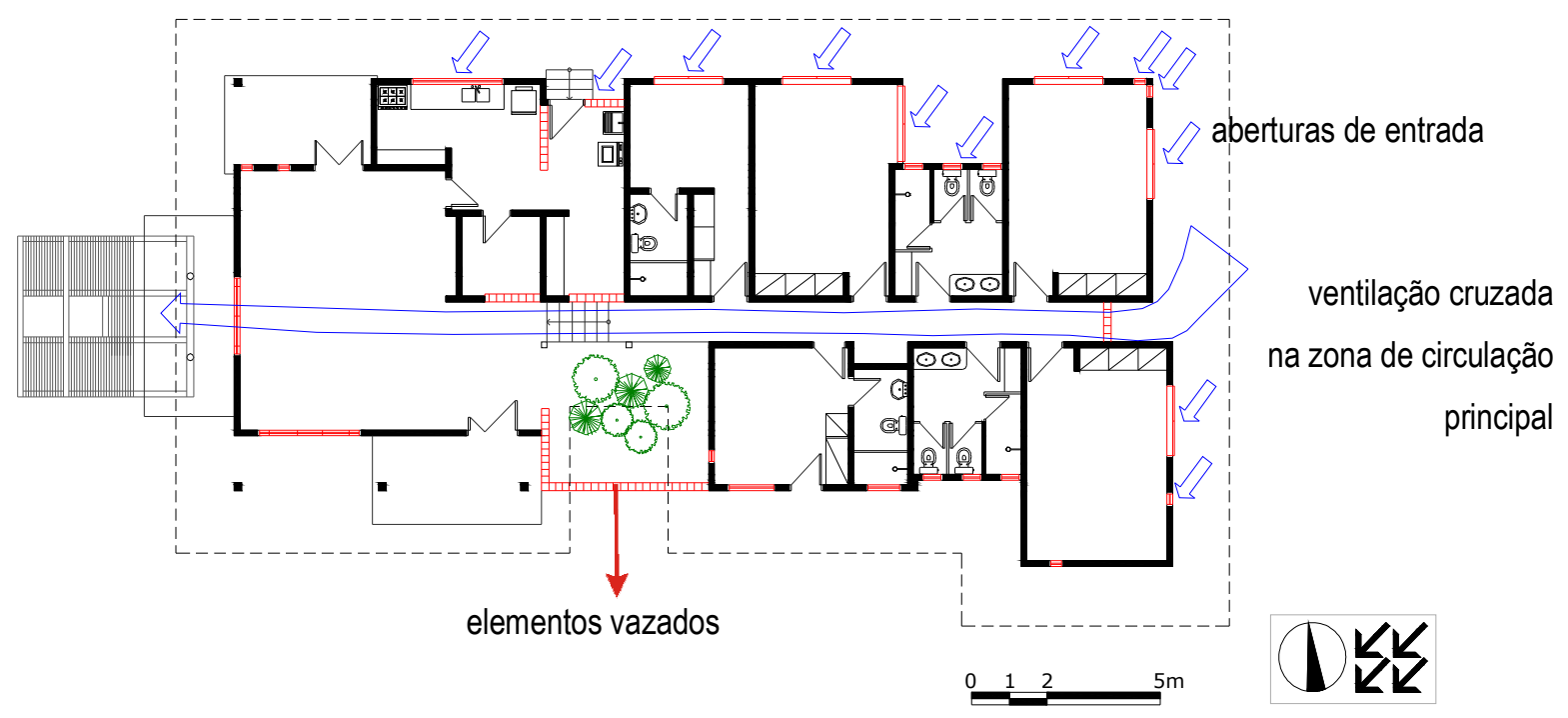

Figura 10.16: Planta da casa-lar - esquema de ventilação

A forma alongada das habitações permitiu a disposição de aberturas na direção dos ventos dominantes nos principais ambientes, resultando em uma ventilação cruzada que percorre todo o corpo principal do edifício. Pequenas reentrâncias e saliências contribuem para captar o fluxo de ar, canalizando-o e direcionando-o para o interior da habitação. Elas permitem também que haja um maior número de aberturas voltadas para a área externa, o que influi não só na ventilação, mas também na iluminação interna. A disposição de aberturas e a distribuição dos espaços internos foram pensadas visando privilegiar a ventilação cruzada. O eixo de circulação central da casa constitui um percurso de circulação do ar, formado por uma parede de elementos vazados a Leste, que é a abertura de entrada do ar, e uma esquadria a Oeste, que é a abertura de saída do ar.

A presença de elementos vazados em alguns pontos da casa (jardim interno, corredor de circulação e cozinha) proporciona ventilação constante. Além disso, aberturas situadas próximas à cobertura nas duas extremidades da edificação (grelhas de madeira, tipo muxarabi) e a ausência de forro em todo 0 corredor de circulação principal permitem ventilação cruzada logo abaixo do telhado, auxiliando na dissipação do calor advindo da radiação solar incidente na cobertura (figura 10.17). A abertura da fachada Oeste, no entanto, possui apenas $0,46 \mathrm{~m}^{2}$, sendo que há espaço para uma abertura maior, 
como mostra a figura 10.18, o que auxiliaria na melhor circulação do ar.

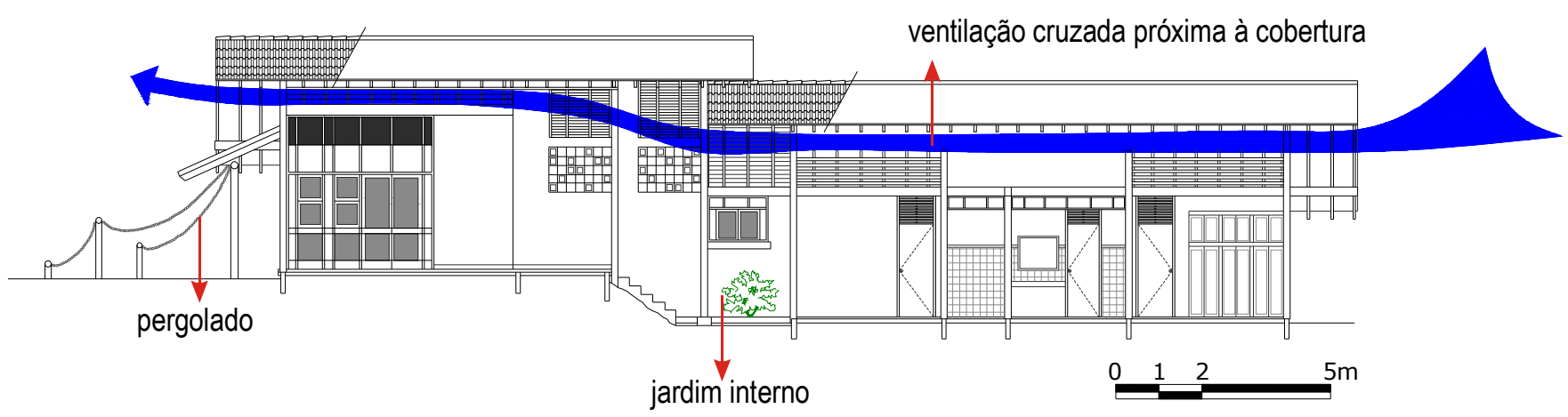

Figura 10.17: Corte longitudinal

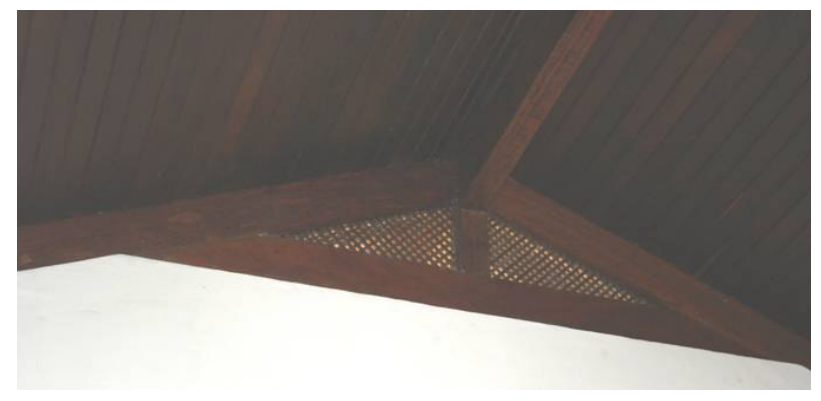

Figura 10.18: Abertura próxima à cobertura na fachada Oeste

As esquadrias foram projetadas para auxiliar no fluxo de ar. Possuem aberturas separadas em alturas diferentes, o que permite direcionar o vento de acordo com a necessidade, podendo passar ou não pela zona de atividade. As esquadrias da sala possuem dois mecanismos de abertura (figura 10.19): as folhas de número 2 são pivotantes horizontais, o que permite controlar a quantidade e o direcionamento do fluxo de ar para o ambiente interno, e possuem venezianas móveis, o que, além de permitir controle de direção do vento, também favorece o controle da iluminação natural; as folhas de número 4 são compostas por venezianas horizontais fixas, sempre abertas para fluxo de ar. Já as partes de números 1 e 3 são fixas e fechadas, sendo a 1 de vidro incolor e a 3 de madeira. As imagens a seguir mostram as diversas possibilidades de abertura: 

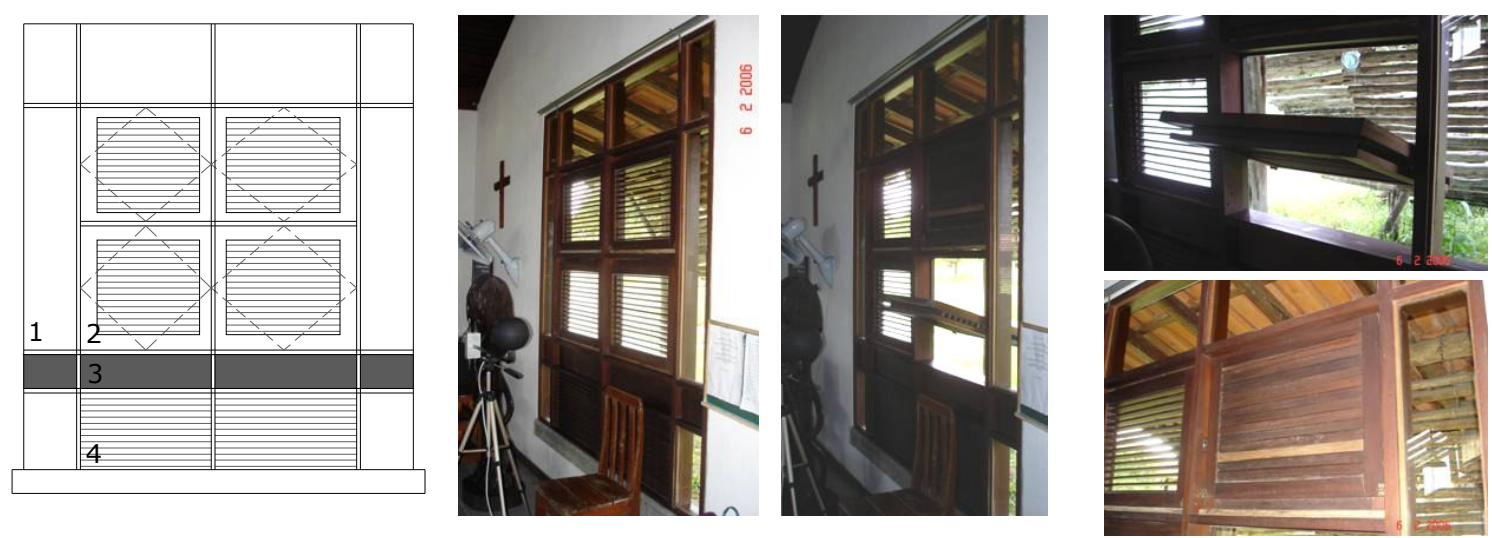

Figuras 10.19 a 10.23: Esquadria da sala - diversos esquemas de abertura

Para auxiliar na circulação constante do ar, a porta de entrada localizada na fachada Norte e a área acima de todas as portas internas da residência também possuem venezianas fixas, como mostram as figuras 10.24 e 10.25 .

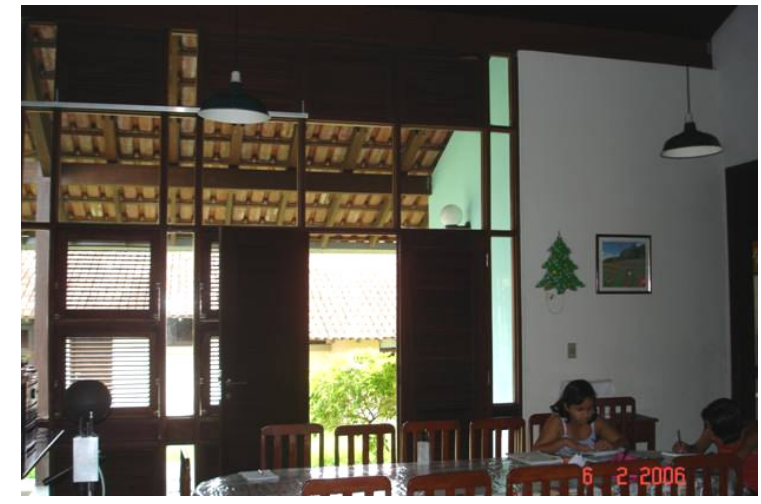

Figura 10.24: Entrada da fachada Norte

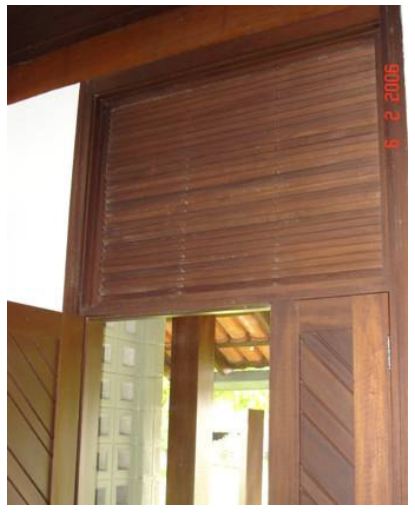

Figura 10.25: Abertura acima das portas internas

Nos quartos, existem dois tipos de esquadrias, que possuem esquema de funcionamento semelhante à sala: a parte inferior é formada por venezianas fixas (número 3), para ventilação constante na altura das pessoas deitadas; e a parte superior possui venezianas móveis de dois esquemas de abertura, as esquadrias maiores são de correr (número 1) e as esquadrias menores são pivotantes horizontais (número 2), ambas com possibilidade de abertura das venezianas em separado. 0 sistema de correr possui trilhos pelo lado externo da edificação, e permite $100 \%$ de área real de abertura. As figuras a seguir mostram o funcionamento das esquadrias: 

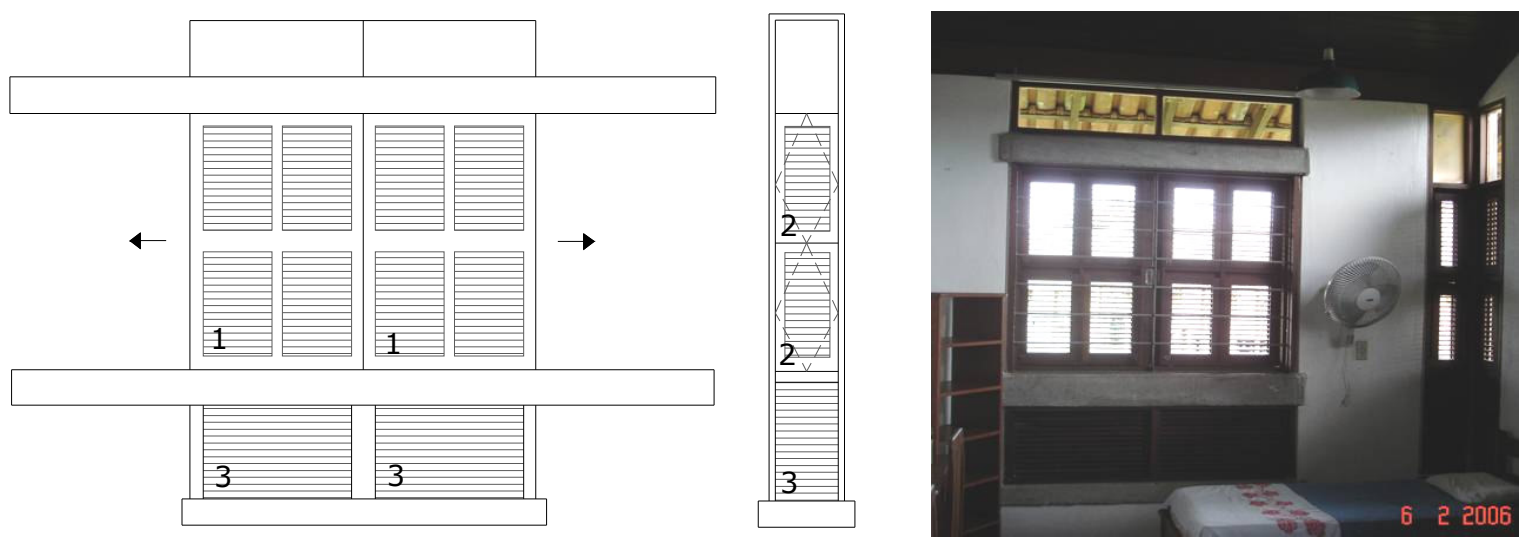

Figuras 10.26 a 10.28: Esquadria dos quartos - diversos esquemas de abertura

Além da ventilação cruzada, o arquiteto também faz uso do efeito chaminé. Nos quartos, o forro de madeira é formado por dois planos inclinados, cuja cumeeira consiste em uma pequena abertura resultante do encontro do forro com a cobertura. A intenção do arquiteto era de que esta abertura funcionasse como saída do ar do interior dos quartos, e extração através do corredor de circulação principal, onde há uma corrente cruzada. Entretanto, seu tamanho reduzido dificulta a ocorrência do efeito - possui apenas $10 \mathrm{~cm}$ de largura e uma área total de $0,37 \mathrm{~m}^{2}$ (figuras 10.30 e 10.31). Outro fator desfavorável é a diferença de altura entre as aberturas de entrada e saída do ar, que é de apenas $2,2 \mathrm{~m}$, um tamanho que, em geral, não é suficiente para que haja um gradiente razoável de temperatura. O pé direito do quarto, na direção da cumeeira, é de 3,5m.

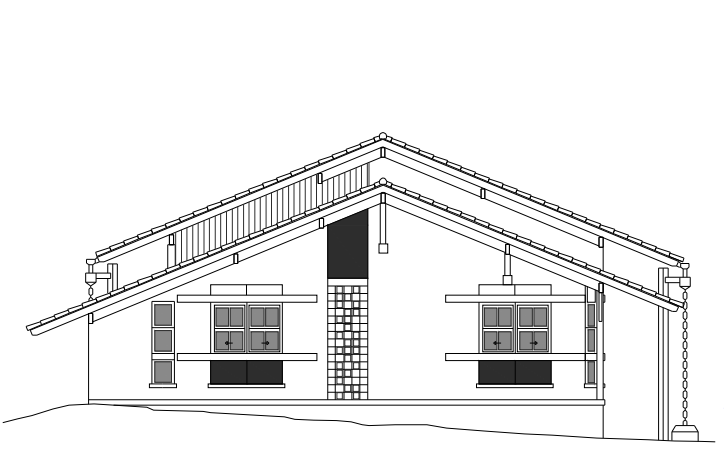

Figura 10.29: Fachada Leste - aberturas dos quartos das crianças e elementos vazados da circulação

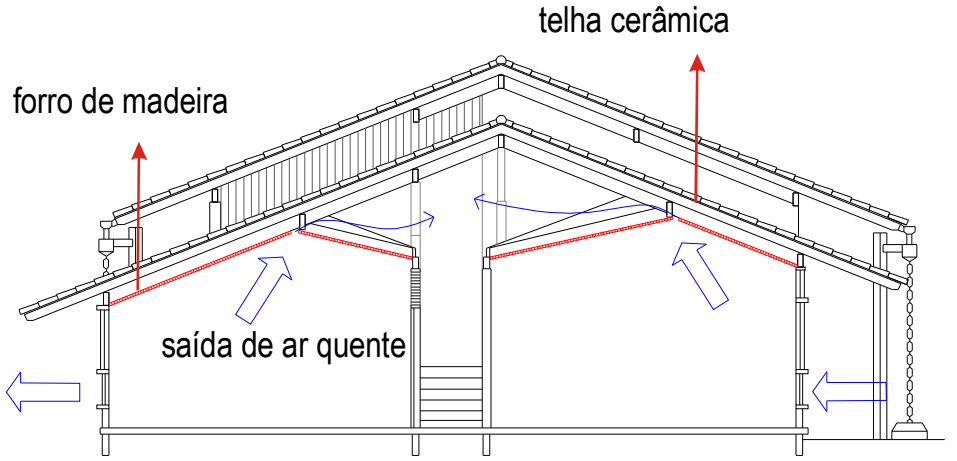

Figura 10.30: Corte transversal - saída de ar quente dos quartos 


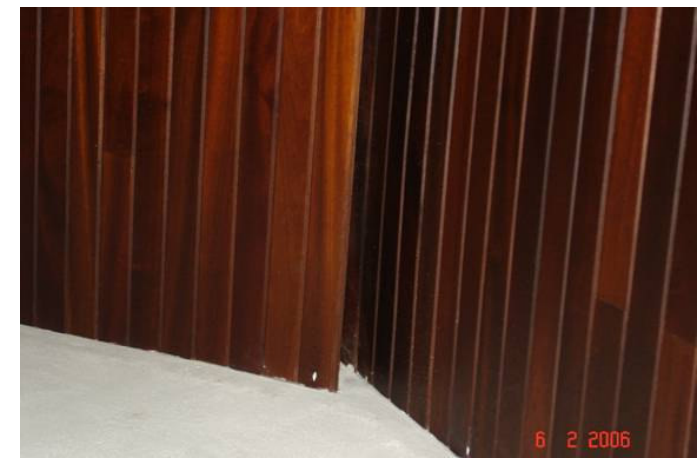

Figura 10.31: Saída de ar quente do forro dos quartos

Uma primeira leitura de projeto da Aldeia mostra que houve uma preocupação constante em utilizar estratégias bioclimáticas em todo o conjunto, desde a fase inicial, visando a melhor adaptação possível ao clima quente e úmido. Foi dada atenção especial a elementos importantes para obtenção de ventilação natural na edificação, principalmente cruzada. Entretanto, quanto aos dados de projeto de ventilação por efeito chaminé, pode-se inicialmente afirmar que o mecanismo não deve funcionar de maneira adequada, devido às reduzidas dimensões, tanto de altura como da abertura de saída do ar. Esta obra, uma das últimas projetadas por Porto em Manaus, mostra um refinamento das soluções utilizadas em esquadrias e aberturas, através do detalhamento cuidadoso das soluções utilizadas e da procura em proporcionar o maior e mais variado número de aberturas.

\subsubsection{As Aldeias Infantis hoje}

A aldeia possui menos de dez anos de construção (foi concluída em 1997), e se apresenta, de maneira geral, em bom estado de conservação. A cobertura do chapéu de palha, porém, apresenta diversas partes descobertas e necessita de manutenção, pois a palha é um material de curta duração, que exige troca freqüente. $O$ pergolado existente na fachada Oeste das casas-lares também apresenta elevado estado de deterioração, devido ao fato da madeira ficar exposta diretamente ao sol e à chuva.

A manutenção das casas-lares é de responsabilidade tanto da administração da aldeia como das mães sociais, e algumas reformas e modificações já foram empreendidas. Uma modificação executada em todas as casas, cujo projeto não foi realizado pelo arquiteto Severiano Porto, foi a ampliação da área de serviço, através da construção de um muro de elementos vazados em frente à cozinha. Os elementos vazados utilizados foram do mesmo tipo do restante da residência. 

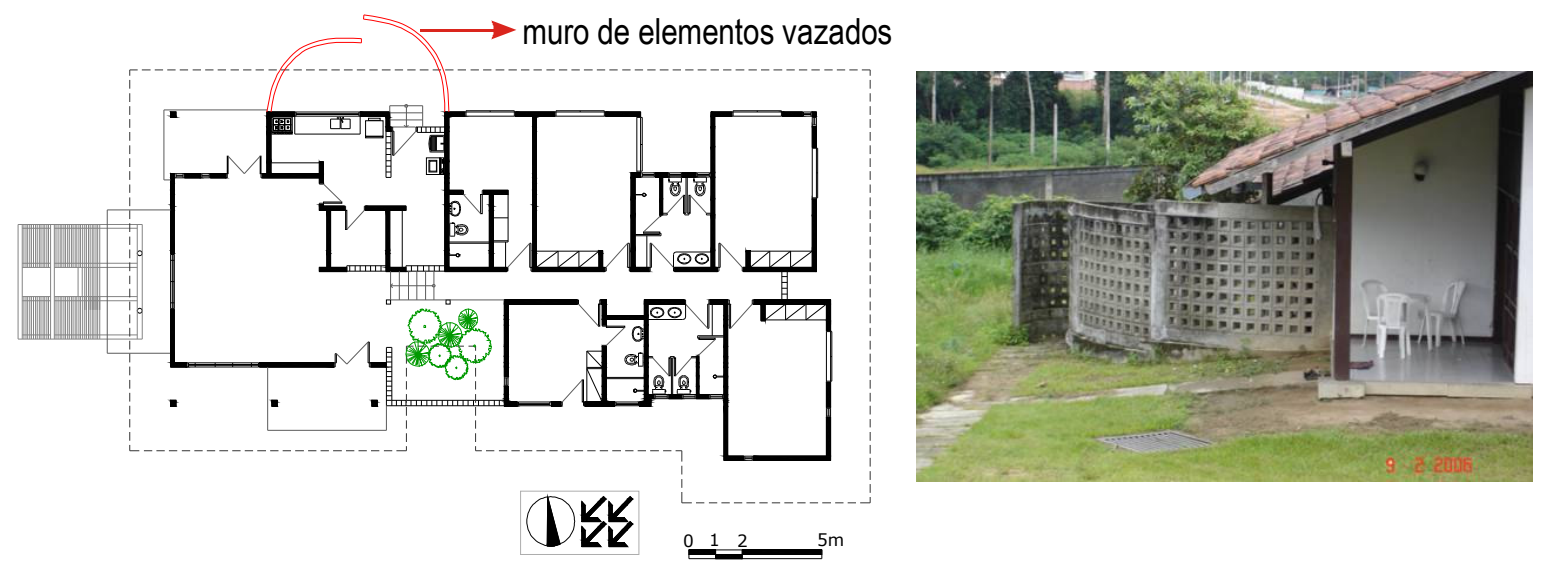

Figuras 10.32 e 10.33: Ampliação da área de serviço

Modificações pontuais também foram realizadas, de acordo com as requisições de cada mãe-social: 0 jardim interno, que originalmente possui uma área aberta na cobertura, em algumas casas foi coberto, por reclamação de penetração de água da chuva; algumas casas também foram pintadas de cores diferentes do branco, que é a cor original da pintura. A casa-lar escolhida para realização da análise quantitativa apresenta 0 jardim interno de acordo com a configuração original do projeto, e a pintura externa é na cor verde claro.
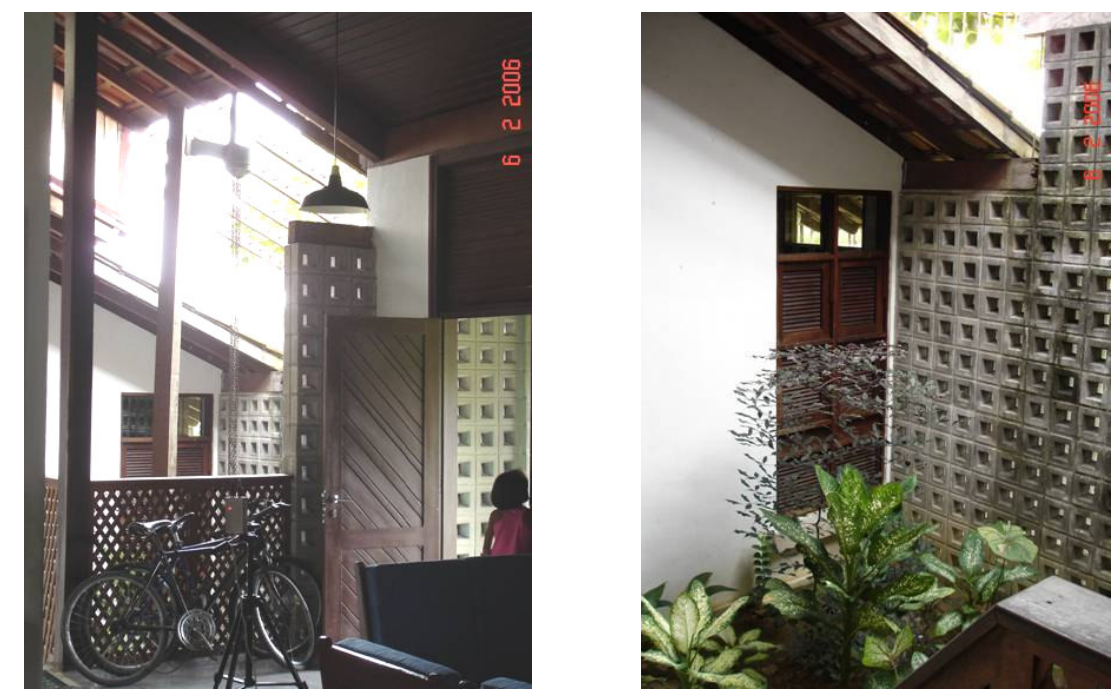

Figuras 10.34 e 10.35: Jardim interno em sua configuração original - água da chuva pode penetrar pela abertura na cobertura 


\subsection{ANÁLISE QUANTITATIVA}

A pesquisa de campo para medições de variáveis térmicas foi realizada na semana de 6 a 13 de fevereiro de 2006, em uma das casas-lares da Aldeia, gentilmente cedida pela mãe Lúcia para a realização do levantamento. Nesta casa vivem, juntamente com a mãe-social, oito crianças, que se encontravam na residência durante todo o período de realização da pesquisa, pois estavam de férias escolares. A indicação da casa-lar analisada apresenta-se na figura seguinte:

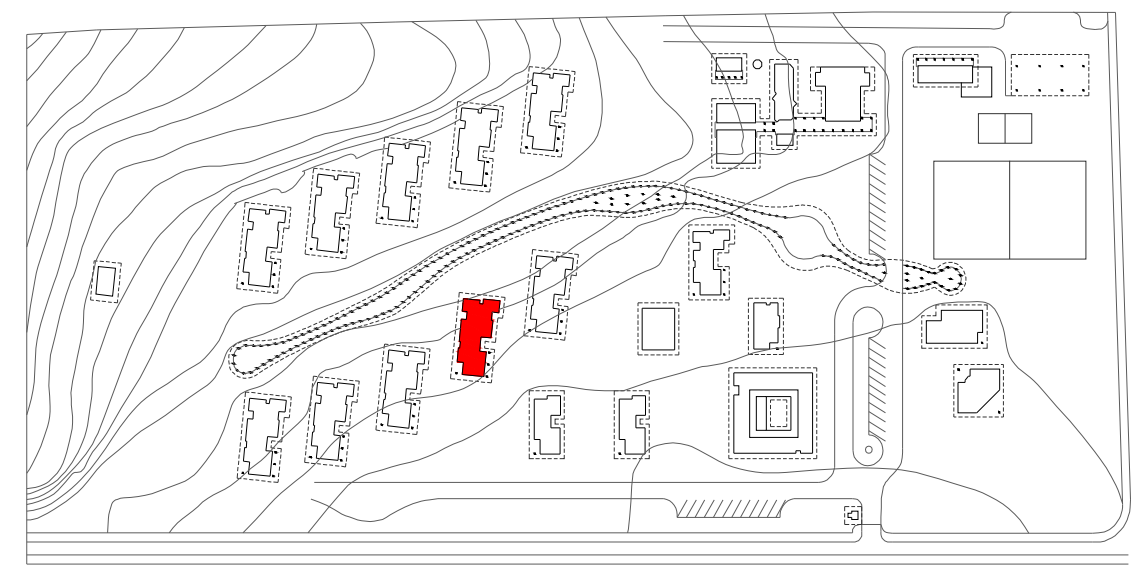

Figura 10.36: Casa-lar escolhida para análise

As medições de temperatura e umidade foram realizadas nos seguintes pontos: 0 ponto 1 está localizado na sala; o ponto 2 está no corredor de circulação que leva aos quartos, na área entre o forro de madeira e a cobertura; o ponto 3 está no quarto das crianças; os pontos 4 e 5 são externos e estão sob o beiral, o primeiro na fachada Norte e o segundo na fachada Oeste. A localização dos pontos pode ser vista na figura 10.37. As medições foram realizadas ininterruptamente pelo período de uma semana, em intervalos de 15 minutos.

Para a análise de ventilação natural, foram escolhidos dois ambientes internos da casa, de acordo com a disponibilidade da família: a sala e o quarto de crianças localizado na fachada Sul (figura 10.37). A descrição sobre as condições de monitoramento destes ambientes está no item a seguir. 

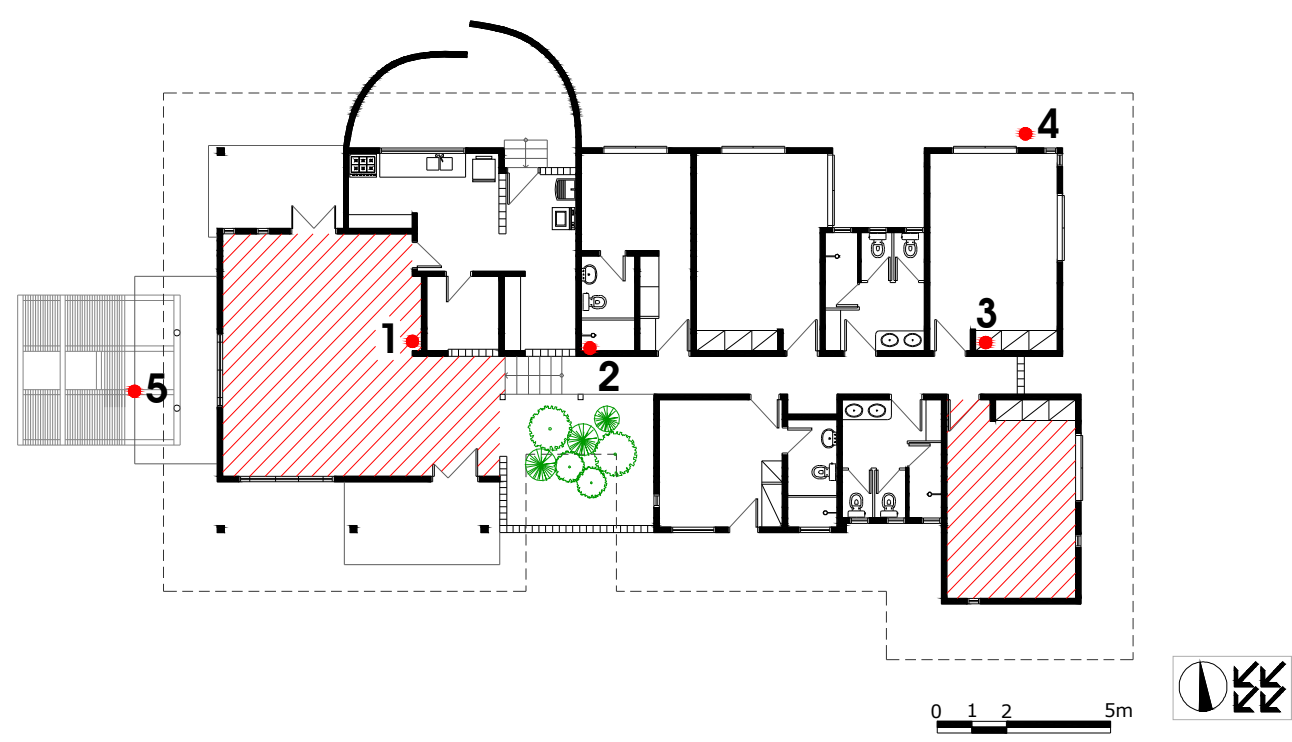

Figura 10.37: Indicação dos pontos onde foram instalados os equipamentos de medição de temperatura e umidade, e dos ambientes onde foram realizadas medições de ventilação natural

\subsubsection{Caracterização dos ambientes escolhidos para análise}

Para análise dos resultados obtidos no monitoramento, faz-se necessária uma descrição minuciosa dos ambientes onde foi realizada a pesquisa. Inicialmente, apresenta-se a tabela abaixo com a especificação de materiais e revestimentos utilizados na construção da casa-lar:

Tabela 10.1 - Materiais construtivos e revestimentos dos ambientes internos

\begin{tabular}{|l|l|}
\hline \multicolumn{1}{|c|}{ Componente do edifício } & \multicolumn{1}{c|}{ Material } \\
\hline Cobertura & Telha cerâmica tipo colonial \\
\hline Estrutura da cobertura & Madeira \\
\hline Forro & Madeira \\
\hline Vedações & Tijolo cerâmico vazado (esp. 15cm) \\
\hline Revestimento externo das vedações & Reboco + pintura verde clara \\
\hline Revestimento interno das vedações & Reboco + pintura branca \\
\hline Revestimento do piso & Cerâmica \\
\hline Esquadrias & Madeira e vidro incolor comum \\
\hline
\end{tabular}

\subsubsection{Sala}

A sala da casa-lar possui $6,8 \mathrm{~m}$ por $5,5 \mathrm{~m}$. Há aberturas em todas as paredes para a ocorrência de ventilação cruzada. As aberturas de entrada do ar estão dispostas nas fachadas Norte, compondo um 
total de $5,3 \mathrm{~m}^{2}$ (40,8\% da fachada), e Leste, onde estão a porta da cozinha e a entrada do corredor de circulação, somando uma área de $3,3 \mathrm{~m}^{2}$. As aberturas de saída do ar estão nas fachadas Oeste $2,6 m^{2}$ (9,6\% da fachada) - e Sul - 6,8m² (24,6\% da fachada), sem contar as aberturas do jardim interno.

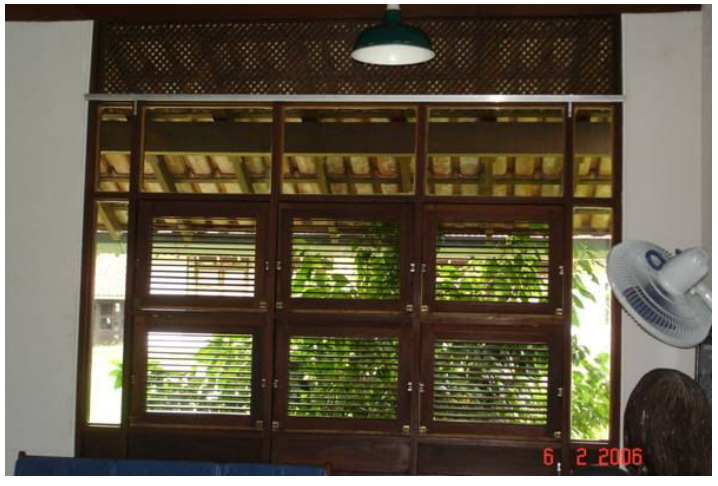

Figura 10.38: Vista da fachada Sul da sala
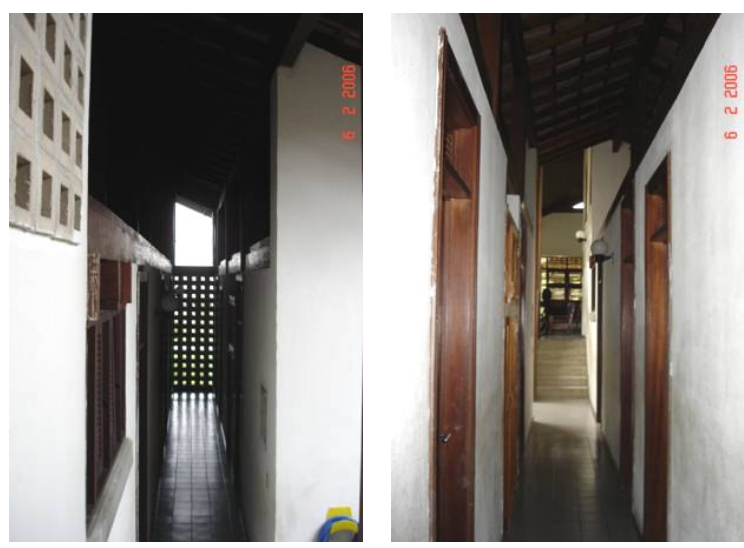

Figuras 10.39 e 10.40: Corredor de circulação

- vistas Leste e Oeste

Através destes dados, pode-se afirmar que as aberturas estão dentro da faixa especificada por Mahoney, que recomenda 40 a $80 \%$ de aberturas nas fachadas Norte e Sul. A sala não possui ático, o forro de madeira fica logo abaixo das telhas de barro. $O$ ambiente possui a seguinte configuração interna:
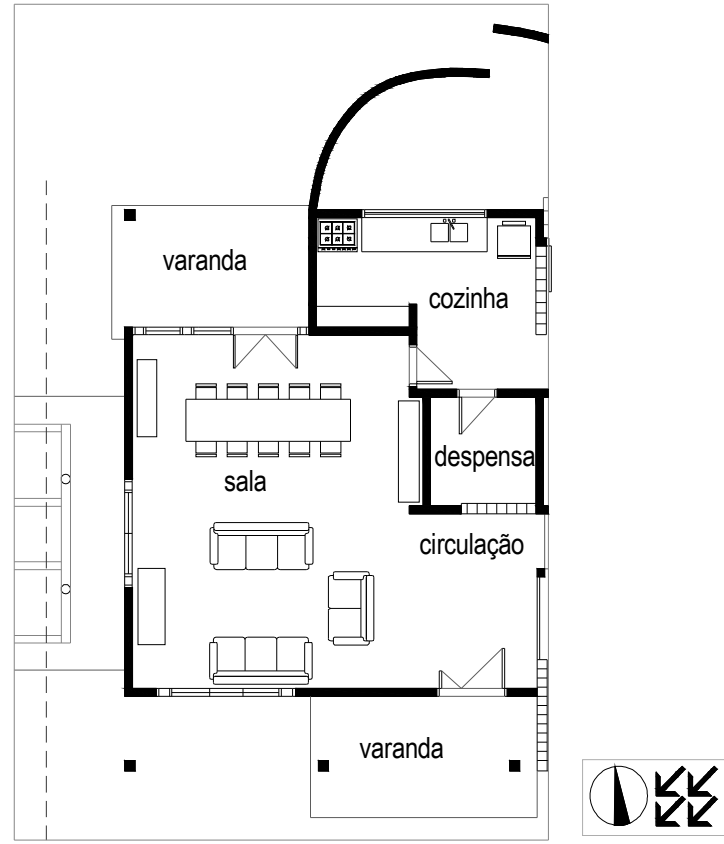

Figura 10.41: Planta da sala 
Durante o monitoramento de velocidade do ar, as aberturas encontravam-se da seguinte forma: a porta da fachada Norte estava com uma das folhas aberta, a porta da fachada Sul estava aberta, todas as esquadrias estavam com o sistema pivotante fechado e as venezianas móveis abertas. Como a família estava ocupando a casa durante todo o período de medições, não foram alterados posicionamento ou abertura de esquadrias e portas, que estavam conforme foi deixado pelos moradores.

\subsubsection{Quarto das crianças}

O quarto das crianças localizado na fachada Sul possui $5,6 \mathrm{~m}$ por 3,7m. As aberturas de entrada do ar possuem $2,94 \mathrm{~m}^{2}$ de área real de abertura ( $29 \%$ da fachada Leste). As aberturas de saída do ar são compostas pela porta - $1,92 \mathrm{~m}^{2}$ - e uma esquadria na fachada Sul com $0,43 \mathrm{~m}^{2}$ de área de abertura (apenas 5,4\% da fachada). Além disso, existe uma abertura no forro para ocorrência de efeito chaminé, com $0,37 m^{2}$. Existe um espaço para circulação do ar entre o forro de madeira e a cobertura, que é interligado ao corredor de circulação. A área das aberturas de saída do ar está bastante abaixo dos valores recomendados por Mahoney. A figura 10.42 apresenta a planta do quarto.

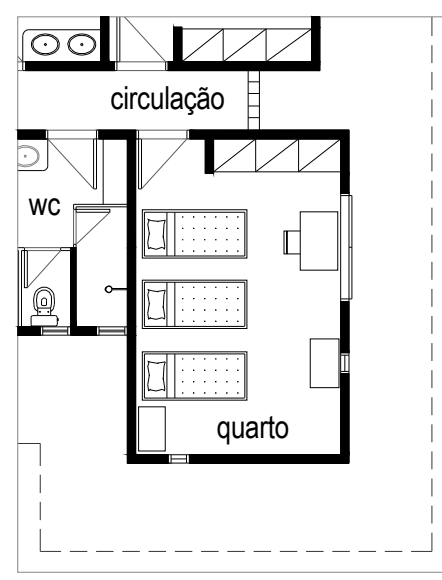

Figura 10.42: Planta do quarto das crianças, fachada Sul
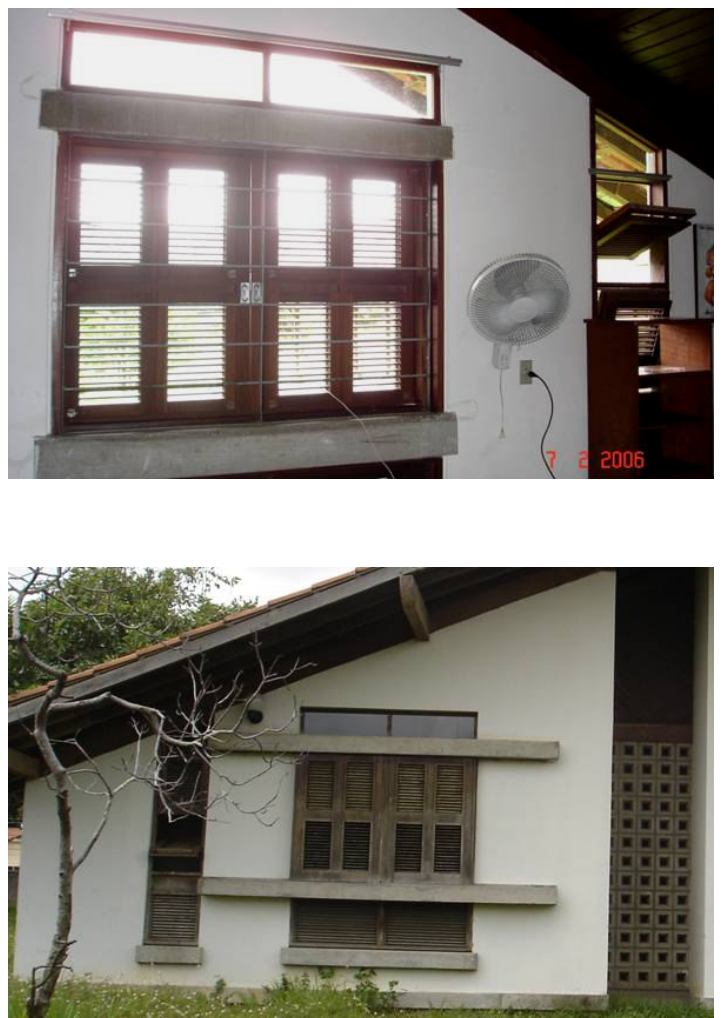

Figuras 10.43 e 10.44: Esquadrias do quarto, fachada Leste - vistas interna e externa 
Quando foram realizadas as medições de velocidade do ar, a esquadria de correr (abertura maior da fachada Leste) estava fechada, e apenas as venezianas móveis estavam abertas. A esquadria ao lado, que possui duas folhas pivotantes, estava com a folha superior aberta e a folha inferior fechada, pois existe uma estante na frente que impede sua abertura. A esquadria localizada na fachada Sul estava com a folha pivotante aberta. A porta também se encontrava aberta.

\subsubsection{Dados obtidos para temperatura e umidade}

O gráfico apresentado a seguir refere-se aos dados de temperatura obtidos nos pontos 2,3 e 4, ou seja, o ponto localizado no corredor, entre o forro e a cobertura; o ponto localizado no quarto das crianças da fachada Norte e o ponto externo (fachada Norte).

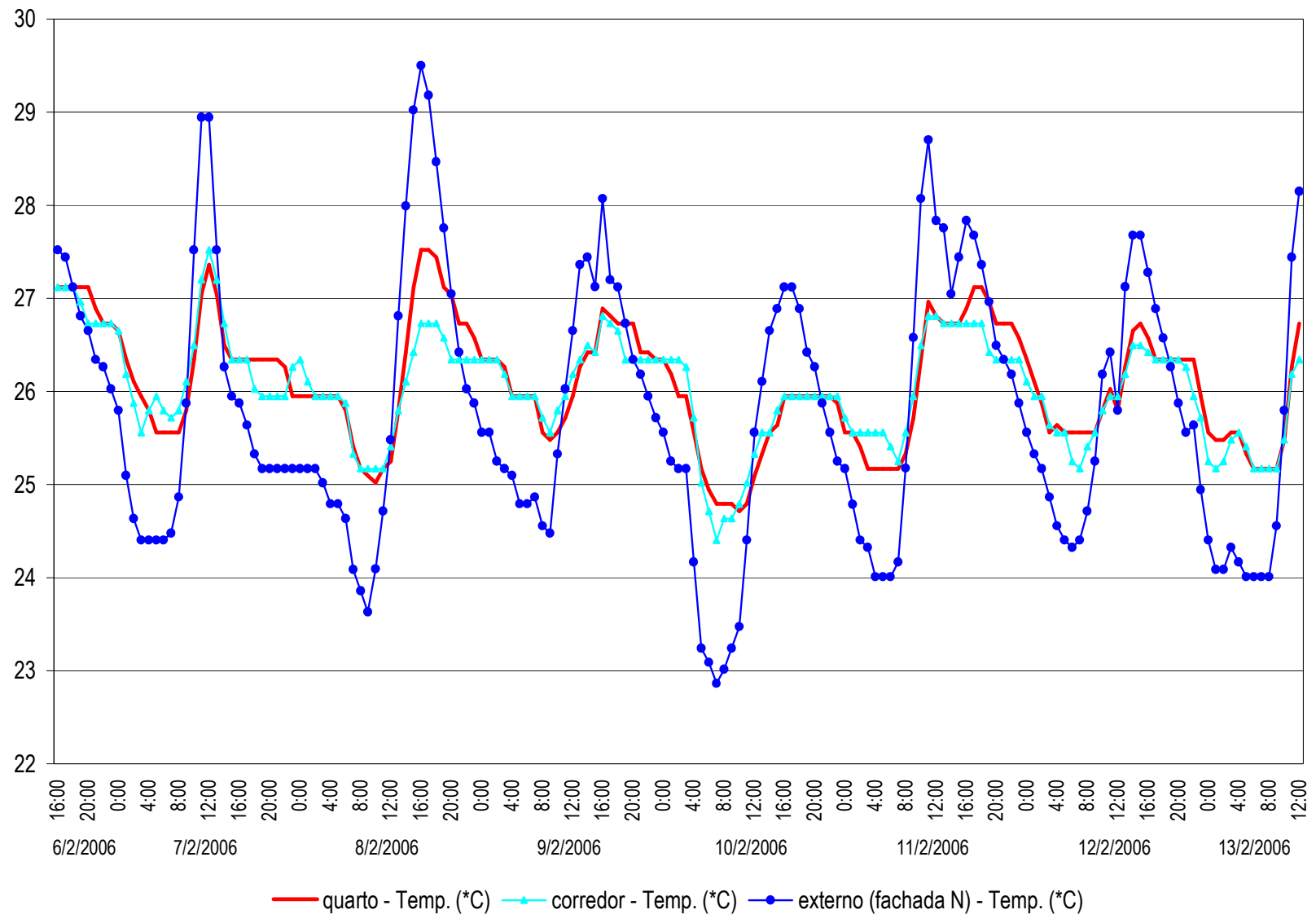

Gráfico 10.1: Temperatura do ar $\left({ }^{\circ} \mathrm{C}\right.$ ) - quarto (ponto 3) $x$ corredor (ponto 2) $x$ externo (ponto 4) 
Durante todo o período em que foi realizada a pesquisa de campo nas obras de Severiano Porto, a semana de monitoramento da Aldeia foi a que apresentou os menores valores de temperatura externa. Foi uma semana de tempo caracteristicamente nublado e com chuvas fracas. A média de temperatura externa obtida foi de $25,8^{\circ} \mathrm{C}$. A oscilação da temperatura foi baixa, sendo a média das máximas de $28,6^{\circ} \mathrm{C}$ e a média das mínimas de $23,8^{\circ} \mathrm{C}$, o que deu uma amplitude média de $4,8^{\circ} \mathrm{C}$. A umidade externa manteve-se constantemente elevada, sendo superior a $75 \%$ na maior parte do período. $\mathrm{A}$ média da semana foi de $84,8 \%$

Pelo gráfico 10.1, pode-se observar a presença de um amortecimento relativamente acentuado da temperatura no ambiente interno em relação à temperatura externa. Para o quarto, 0 amortecimento médio da semana foi de $1,65^{\circ} \mathrm{C}$; para o corredor o valor foi praticamente o mesmo $\left(1,78^{\circ} \mathrm{C}\right)$. Já 0 atraso térmico não foi significativo, ficando em um valor aproximado de 30 minutos. A temperatura média interna, calculada para o quarto, foi de $26,1^{\circ} \mathrm{C}$, pouco superior à media externa, e a amplitude média ficou em $1,9^{\circ} \mathrm{C}$. Estes valores revelam a presença de uma certa inércia térmica na construção, não muito elevada, já que o atraso térmico foi pequeno.

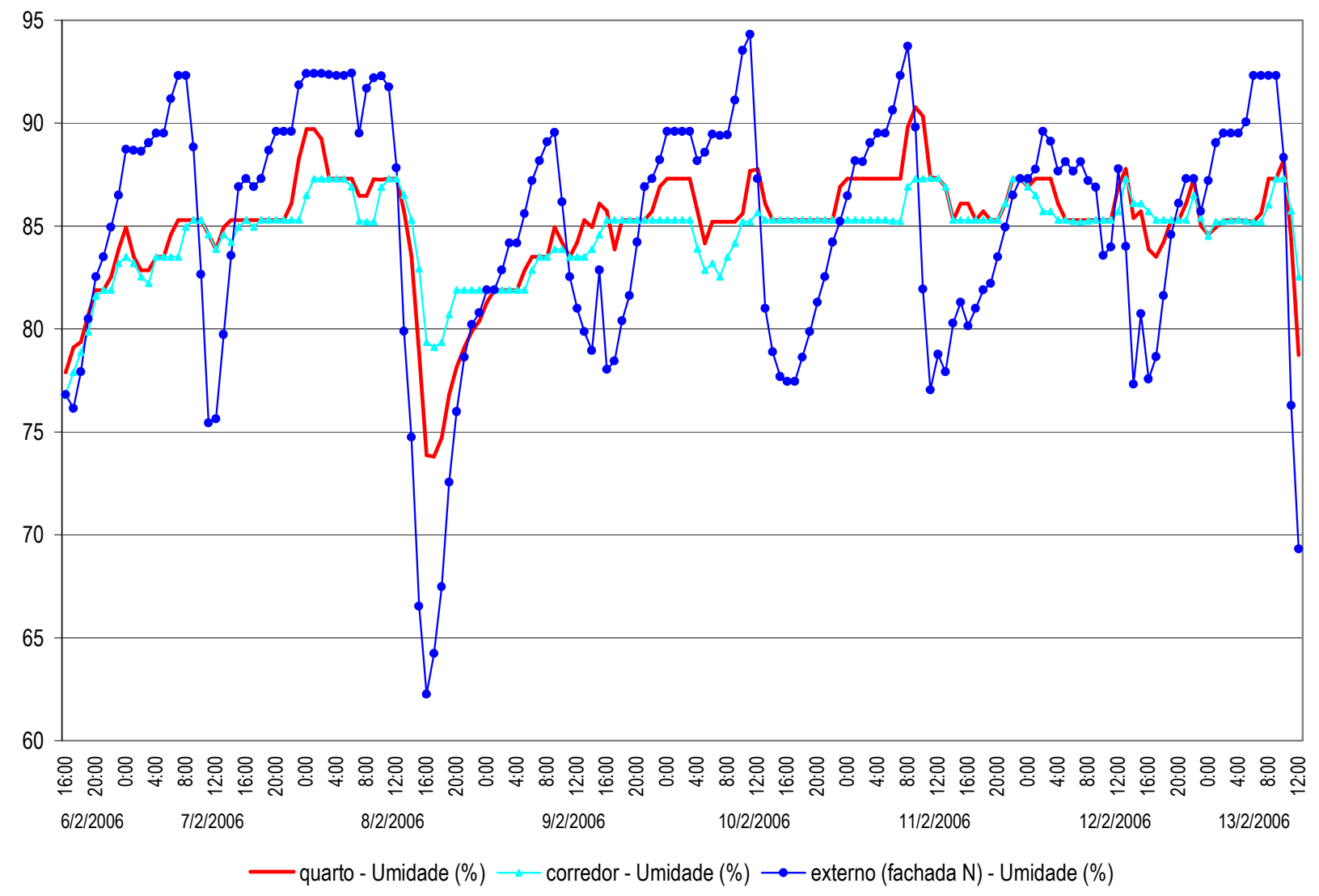

Gráfico 10.2: Umidade relativa do ar (\%) - quarto (ponto 3) x corredor (ponto 2) x externo (ponto 4) 
A umidade relativa do ar, consequentemente, também sofreu um certo amortecimento, que pode ser observado no gráfico 10.2. A umidade média interna foi pouco superior à externa - 84,9\% - o que ocorre devido à presença de ocupantes. A variação entre os picos máximos e mínimos foi mais suave: a média das máximas foi de $88,3 \%$ (4,8\% abaixo da média das máximas externa) e a média das mínimas foi de $82,6 \%$ (10\% acima da externa).

O monitoramento realizado na sala mostrou um comportamento semelhante aos demais ambientes, como mostra o gráfico 10.3 , a seguir. A média das máximas foi de $27,1^{\circ} \mathrm{C}$ e a média das mínimas $25,4^{\circ} \mathrm{C}$, o que também resulta em um amortecimento relativamente acentuado em relação à temperatura externa - uma média de $1,58^{\circ} \mathrm{C}$. 0 atraso térmico também não foi significativo.

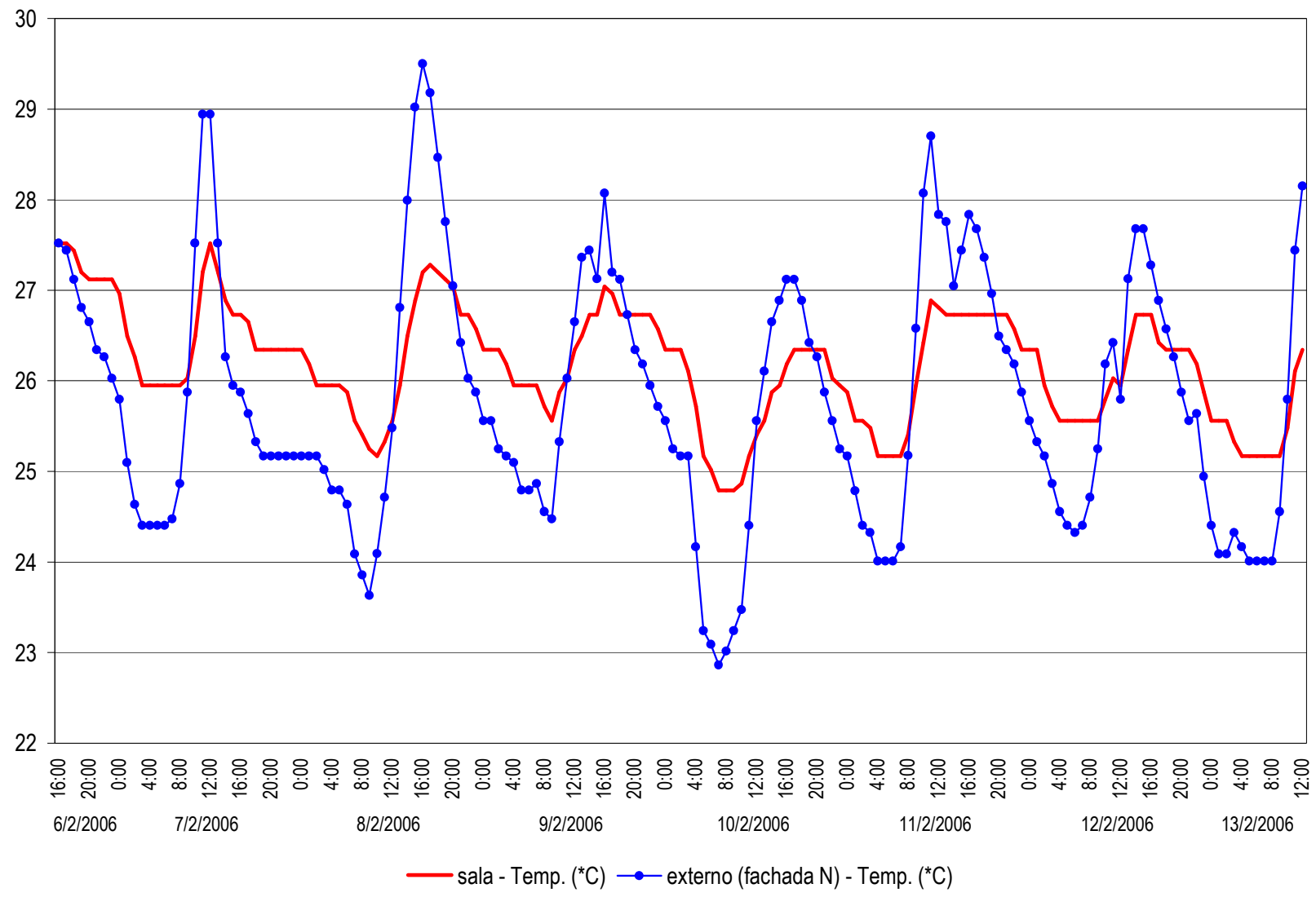

Gráfico 10.3: Temperatura do ar $\left({ }^{\circ} \mathrm{C}\right)$ - sala (ponto 1) x externo (ponto 4

Além do monitoramento realizado sob o beiral da fachada Norte, foram também realizadas medições externas de temperatura e umidade na fachada Oeste, sob o pergolado de madeira. O principal objetivo deste monitoramento foi possibilitar a comparação entre fachadas de diferentes orientações, com relação à provável contribuição da fachada de orientação mais desfavorável, que é a fachada Oeste, 
para aquecimento do ambiente interno. Os dados obtidos para temperatura apresentam-se no gráfico 10.4 .

As diferenças entre os picos de temperatura máxima, para as duas fachadas, foram em média de $1^{\circ} \mathrm{C}$. Além do beiral extenso, existente em todas as fachadas, a fachada Oeste possui uma proteção adicional, proporcionada pelo pergolado de madeira, que contribui para reduzir a radiação solar incidente na parede. Além disso, a porcentagem de aberturas na fachada Oeste é consideravelmente menor do que nas outras fachadas - apenas $9,6 \%$ - o que reduz a incidência de radiação solar e o aquecimento da sala.

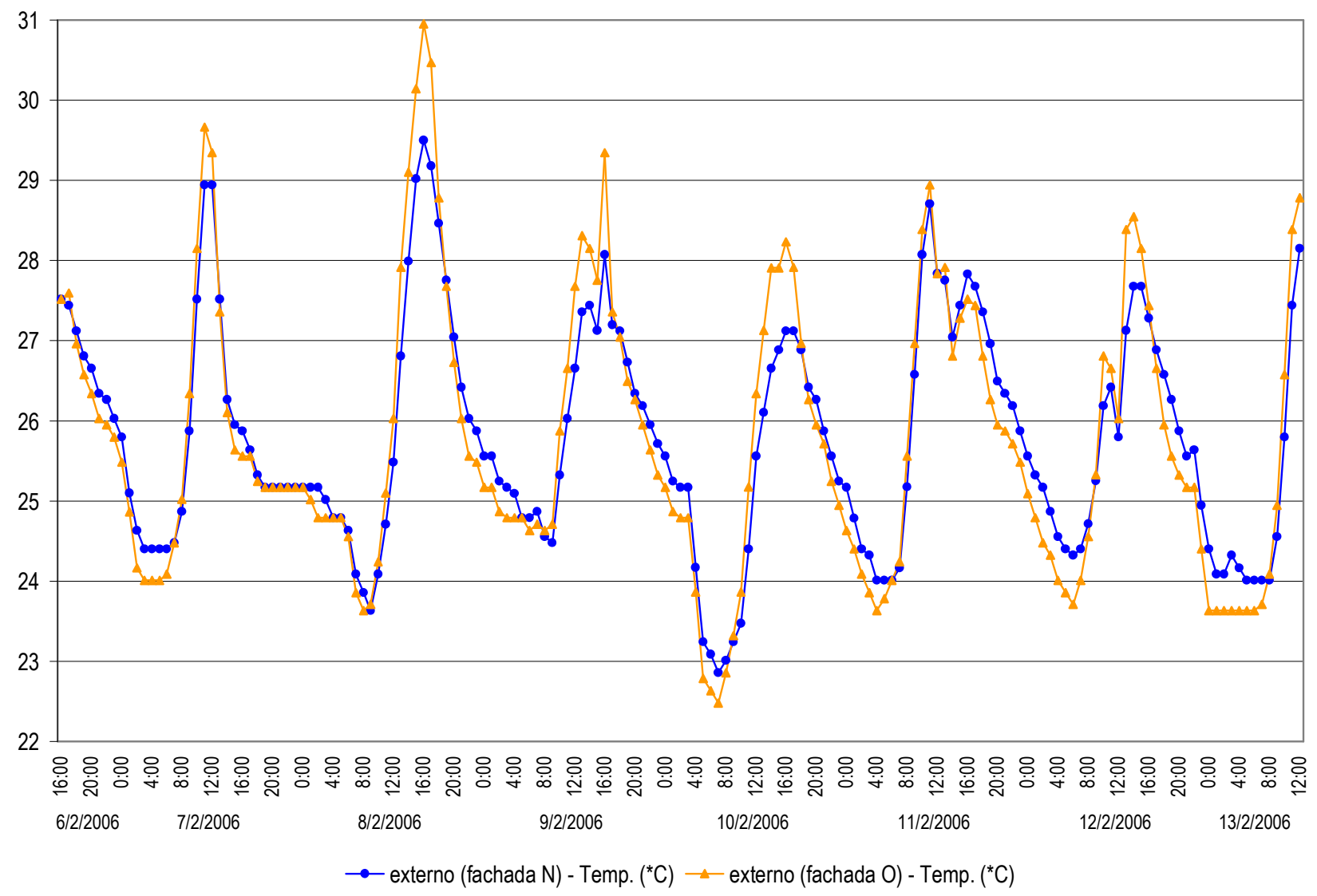

Gráfico 10.4: Temperatura do $\operatorname{ar}\left({ }^{\circ} \mathrm{C}\right)$ - externo - fachada Norte (ponto 4) x externo - fachada Oeste (ponto 5)

\subsubsection{Dados obtidos para velocidade do ar}

Para as medições de velocidade do ar foram escolhidos dois ambientes: a sala e o quarto das crianças 
localizado nas fachadas Sul/Leste. As medições foram feitas a $1,20 \mathrm{~m}$ do piso. Como já foi dito anteriormente, não foi alterado o posicionamento das aberturas, que estavam conforme deixado pelos moradores. As aberturas não foram testadas, portanto, no seu grau máximo de aproveitamento possível do vento livre disponível, pois as janelas pivotantes estavam quase todas fechadas. No entanto, o fato da família encontrar-se na casa durante o monitoramento permitiu avaliar o grau de desempenho da edificação dentro das condições de uso corrente dos moradores.

Os resultados obtidos para a sala apresentam-se no gráfico 10.5, a seguir:

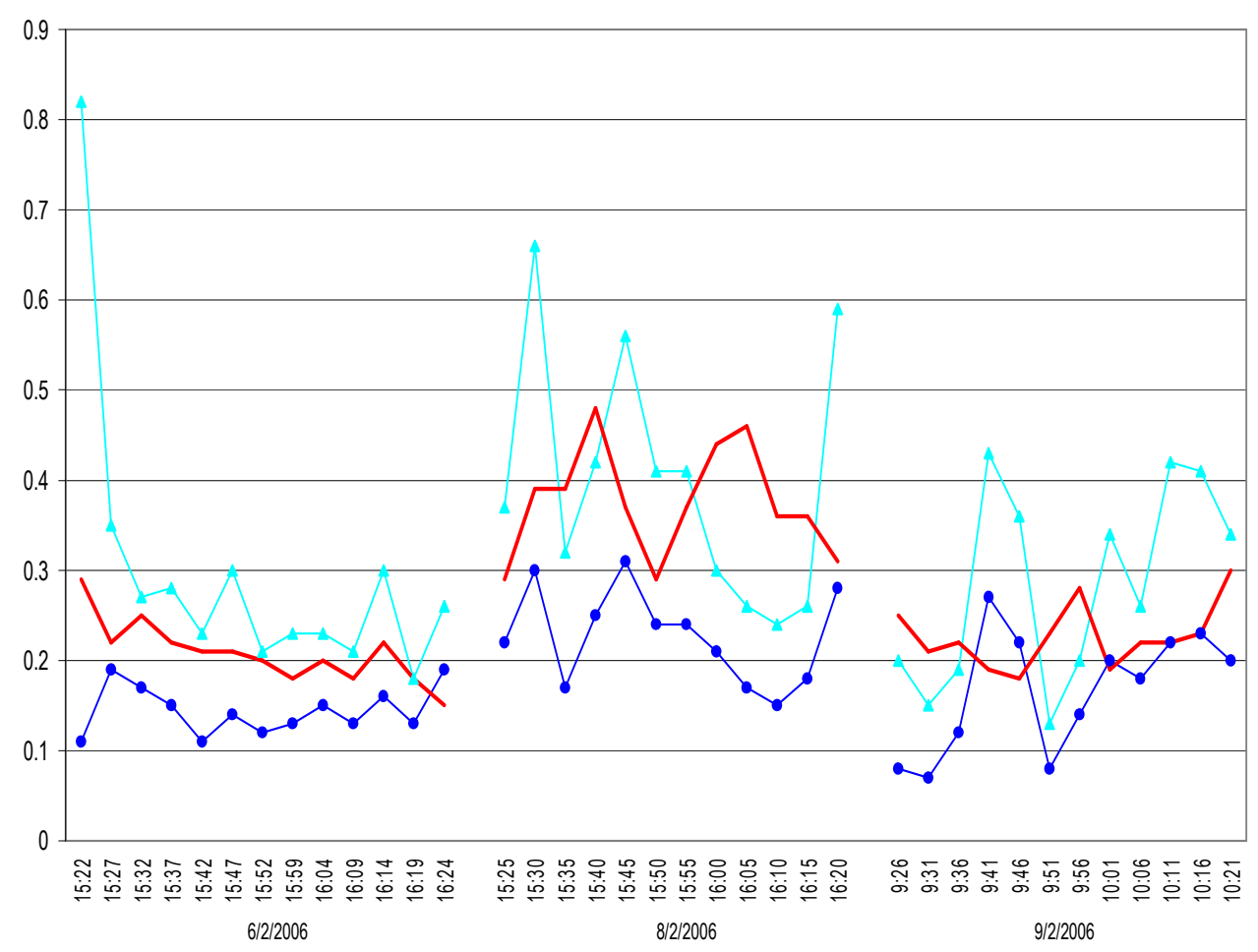

(a)

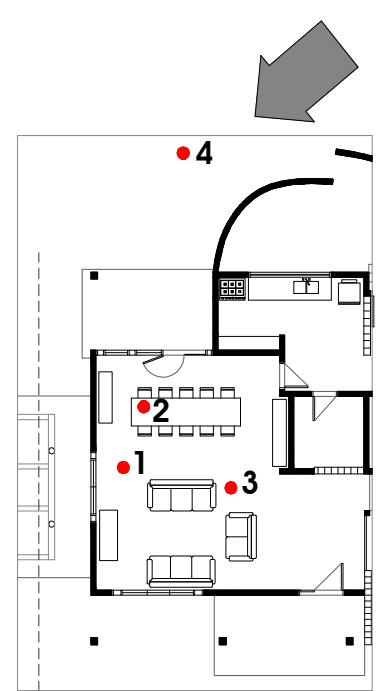

9/2/2006

$\longrightarrow$ Veloc. pto $1(\mathrm{~m} / \mathrm{s}) \longrightarrow$ Veloc. pto $2(\mathrm{~m} / \mathrm{s}) \longrightarrow$ Veloc. pto $3(\mathrm{~m} / \mathrm{s})$

Gráfico 10.5: (a) Sala - velocidade do ar (m/s); (b) Posicionamento dos anemômetros

Os anemômetros numerados de 1 a 3 foram dispostos no ambiente interno e o de número 4 captou a velocidade de vento externa. Houve, porém, um problema com a captação do vento externo, pois o confortímetro registra apenas velocidades entre 0,05 e $3 \mathrm{~m} / \mathrm{s}$, e quando este valor é ultrapassado 0 software acusa erro e registra o valor de $9,99 \mathrm{~m} / \mathrm{s}$. Como o equipamento foi programado para registrar a média a cada cinco minutos, os momentos em que a velocidade do ar ultrapassou $3 \mathrm{~m} / \mathrm{s}$ alteraram e 
invalidaram a média final obtida ${ }^{28}$. Por isso, foi adotada uma média externa de 2,0 a 3,5m/s (não representada no gráfico), baseada na observação da leitura instantânea dada pelo visor do aparelho, durante o monitoramento. É uma média aproximada, mas que permite traçar um perfil geral do vento externo e estabelecer uma base de comparação para os dados obtidos internamente.

Ao observar o gráfico 10.5, pode-se notar que a velocidade do ar interno ficou entre 0,1 e $0,4 \mathrm{~m} / \mathrm{s}$ na maior parte do tempo em que foram realizadas as medições. 0 ponto 2 , localizado próximo à porta de entrada da casa, foi o que apresentou as maiores velocidades, sendo a média da semana de $0,33 \mathrm{~m} / \mathrm{s}$. 0 ponto 3 apresentou uma média de $0,27 \mathrm{~m} / \mathrm{s}$ e o ponto 1 uma média de $0,18 \mathrm{~m} / \mathrm{s}$. São todos valores extremamente baixos, considerando-se que a média do vento livre disponível ficou acima de $2 \mathrm{~m} / \mathrm{s}$. Entretanto, deve ser levado em conta o fato de que todas as esquadrias estavam com os sistemas pivotantes fechados durante as medições, e apenas com as venezianas abertas (opção dos moradores) o que reduz significativamente a área de abertura. Apesar disso, era esperado um desempenho melhor do ponto 3 , que se localiza no eixo de circulação principal da casa, onde foi identificado, na etapa de análise projetual, um eixo de ventilação cruzada (figura 10.15).

Os gráficos a seguir apresentam os resultados obtidos para o quarto. As medições foram feitas a $1,20 \mathrm{~m}$ do piso. Apenas o ponto 2 foi disposto a uma altura de $0,5 \mathrm{~m}$ do piso, que é a altura de uma pessoa deitada na cama. O gráfico 10.6 apresenta o único dia de monitoramento em que houve velocidades de vento externo inferiores a $3 \mathrm{~m} / \mathrm{s}$, sendo possível, portanto, aproveitar os dados registrados pelo confortímetro. Já para as demais medições realizadas no quarto (gráfico 10.7), foi adotada uma média de 2,0 a $3,5 \mathrm{~m} / \mathrm{s}$ para a velocidade do ar externo, pelo mesmo motivo explicitado anteriormente.

${ }^{28}$ Como exemplificação do ocorrido, são apresentados os dados obtidos para a média de velocidade de vento externo do dia 6/2:

\begin{tabular}{|c|c|c|c|c|c|c|c|c|c|c|c|c|c|}
\hline horário & $15: 22$ & $15: 27$ & $15: 32$ & $15: 37$ & $15: 42$ & $15: 47$ & $15: 52$ & $15: 59$ & $16: 04$ & $16: 09$ & $16: 14$ & $16: 19$ & $16: 24$ \\
\hline veloc. $(\mathrm{m} / \mathrm{s})$ & 6.54 & 9.21 & 6.61 & 6.70 & 7.89 & 4.99 & 6.02 & 6.44 & 5.21 & 4.42 & 8.13 & 6.45 & 6.90 \\
\hline
\end{tabular}




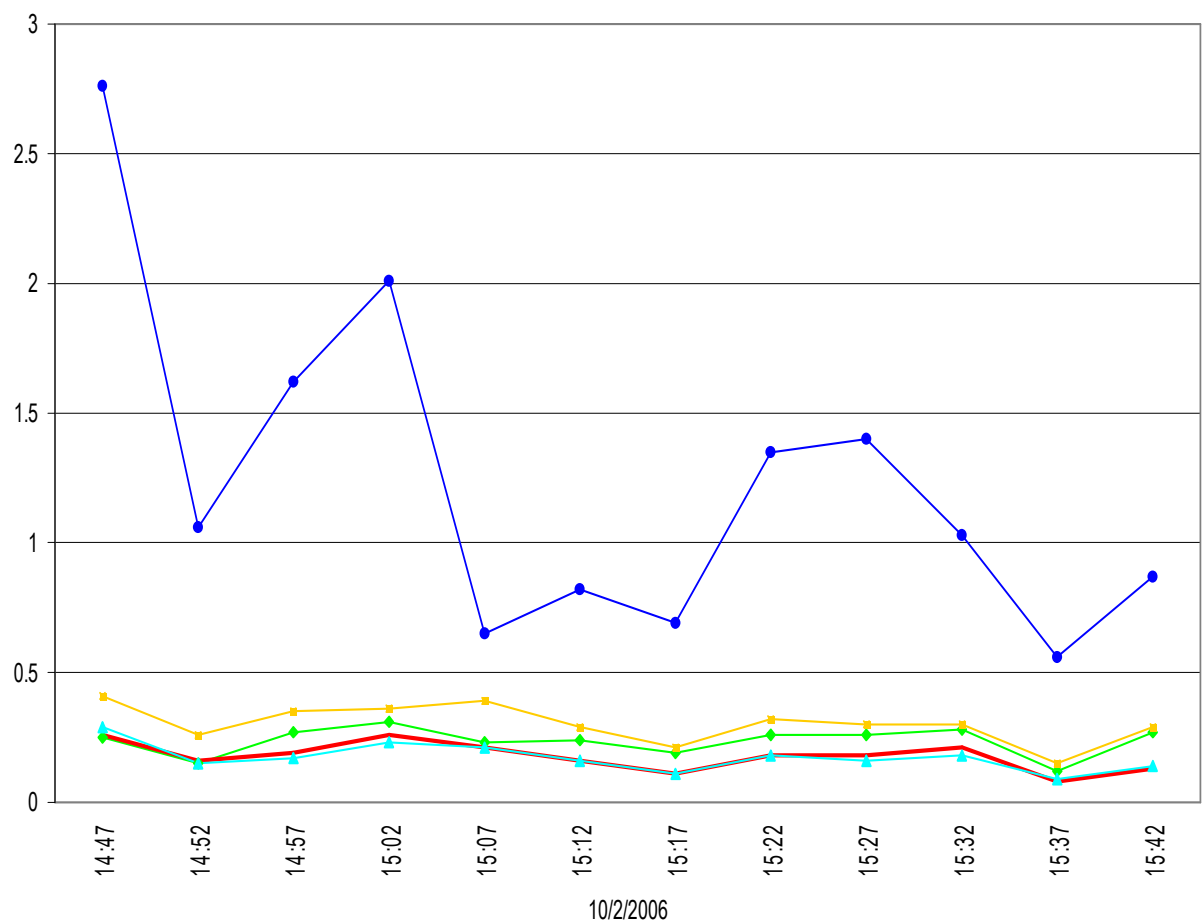

(a)

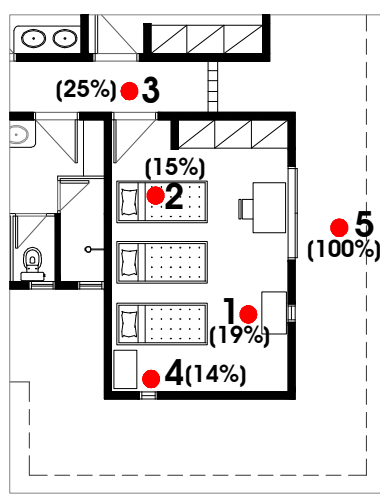

$\longrightarrow$ Veloc. pto $1(\mathrm{~m} / \mathrm{s}) \longrightarrow$ Veloc. pto $2(\mathrm{~m} / \mathrm{s}) \longrightarrow$ Veloc. pto $3(\mathrm{~m} / \mathrm{s}) \longrightarrow$ Veloc. pto $4(\mathrm{~m} / \mathrm{s}) \longrightarrow$ Veloc. pto 5 - externo $(\mathrm{m} / \mathrm{s})$

Gráfico 10.6: (a) Quarto - velocidade do ar (m/s); (b) Posicionamento dos anemômetros

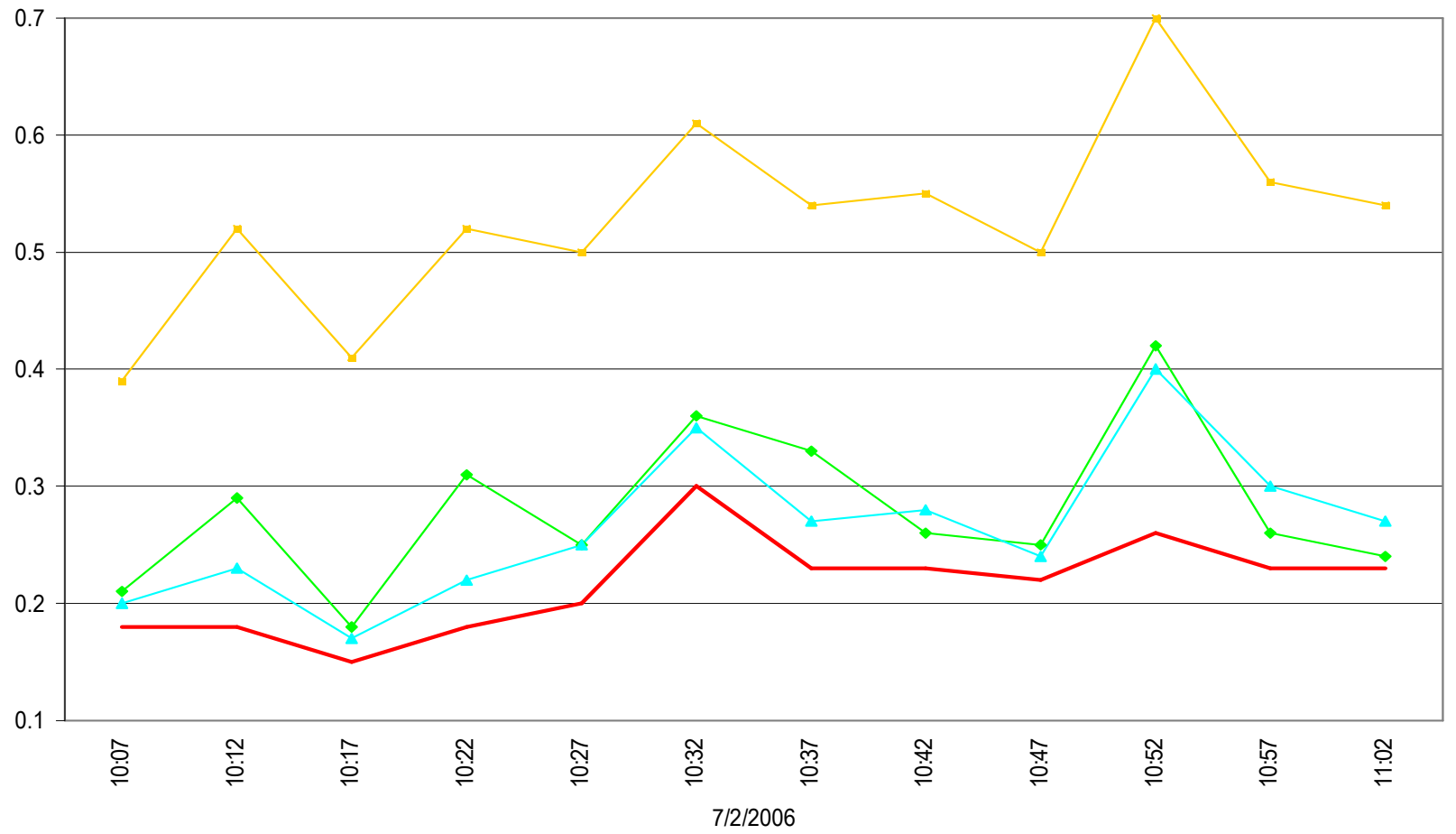

$\multimap$ Veloc. pto $1(\mathrm{~m} / \mathrm{s}) \longrightarrow$ Veloc. pto $2(\mathrm{~m} / \mathrm{s}) \longrightarrow$ Veloc. pto $3(\mathrm{~m} / \mathrm{s}) \longrightarrow$ Veloc. pto $4(\mathrm{~m} / \mathrm{s})$

Gráfico 10.7: Quarto - velocidade do ar $(\mathrm{m} / \mathrm{s})$ 
Observando a porcentagem de velocidade do ar interna em relação ao vento externo disponível (gráfico 10.6), pode-se notar que o aproveitamento do fluxo de ar natural dentro do quarto (pontos 1,2 e 4) foi extremamente baixo, ficando entre 14 e 19\% (média de 0,2 a 0,3m/s). Esta média se manteve no outro dia de monitoramento (gráfico 10.7). Contribuiu para o resultado apresentado o fato da esquadria de correr encontrar-se fechada, apenas com as venezianas abertas, durante as medições, o que reduziu consideravelmente a área de abertura para entrada do ar. 0 ponto 2 , localizado sobre a cama e que deveria ser atingido pelo fluxo de ar que atravessa as venezianas fixas da parte inferior das esquadrias, foi o que apresentou as menores velocidades.

Já o ponto 3, situado no corredor de circulação, apresentou aproveitamento um pouco superior aos demais pontos, obtendo uma média de $0,42 \mathrm{~m} / \mathrm{s}$ para todas as medições efetuadas. Pelo gráfico 10.7 pode-se observar uma velocidade um pouco maior para este ponto, que ainda está, porém, bastante abaixo da velocidade do vento externo. Por estar situado em um local onde foi identificado um eixo de ventilação cruzada e próximo à abertura de entrada do ar (formada pela parede de elementos vazados), era esperado um desempenho mais satisfatório.

\subsection{ANÁLISE DOS RESULTADOS}

Através da utilização dos dados apresentados até o momento e da aplicação dos métodos de análise previamente selecionados, realiza-se neste item uma análise final de desempenho térmico e ventilação natural da casa-lar das Aldeias Infantis.

\subsubsection{Análise de desempenho térmico: temperatura e umidade}

O período em que foi realizado o monitoramento no edifício da casa-lar apresentou temperaturas relativamente baixas, com oscilação mínima no decorrer do dia, devido às características climáticas predominantes da semana e comuns para a época do ano na região - tempo nublado, com chuvas fracas constantes. Os dados obtidos para temperatura externa resultaram em uma média das mínimas de $23,8^{\circ} \mathrm{C}$ e uma média das máximas de $28,6^{\circ} \mathrm{C}$. Conforme já explicitado anteriormente, o intervalo de conforto estabelecido pela ASHRAE Standard 55-2004, para o mês de fevereiro na cidade de Manaus, é de $22,3^{\circ} \mathrm{C}$ a $29,3^{\circ} \mathrm{C}$.

Já que a temperatura externa se manteve dentro da zona de conforto estabelecida pela ASHRAE, e foi 
observado um amortecimento relativamente acentuado dos ambientes internos, não poderia ser esperado outro resultado a não ser o ambiente interno manter-se constantemente dentro do intervalo de conforto. Os valores de temperatura obtidos internamente, inclusive nos períodos mais quentes do dia, ficaram distantes da zona limite: para o quarto situado nas fachadas Norte/Leste, a média das mínimas foi de $25,1^{\circ} \mathrm{C}$ e média das máximas de $27,0^{\circ} \mathrm{C}$; para a sala os valores foram praticamente os mesmos, a média das mínimas foi de $25,4^{\circ} \mathrm{C}$ e a média das máximas de $27,1^{\circ} \mathrm{C}$.

Logo, devem ser analisados mais aprofundadamente o sistema construtivo e os materiais utilizados na construção da edificação, quanto à sua adequabilidade para o clima local. 0 amortecimento observado no monitoramento revela a presença de uma certa inércia térmica na construção. Como esta característica está associada ao material utilizado e sabe-se que uma inércia térmica elevada não é recomendada para construções em clima quente e úmido, uma análise sobre os materiais pode esclarecer melhor esta questão. Para isto, são utilizados os parâmetros estabelecidos por Mahoney.

Mahoney recomenda a utilização de coberturas leves, termicamente isoladas e que reflitam a radiação do sol. Determina um valor de transmitância térmica máximo de $1,1 \mathrm{~W} / \mathrm{m}^{2} \mathrm{C}$ e fator de calor solar igual ou inferior a 4\%. A cobertura da casa-lar é composta por telha cerâmica tipo colonial com forro de madeira. Para uma telha com espessura de $1,0 \mathrm{~cm}$ e um forro de madeira também com espessura de $1,0 \mathrm{~cm}$, situação que se aproxima à encontrada na casa, o valor obtido para transmitância térmica é de $2,0 \mathrm{~W} / \mathrm{m}^{2} \mathrm{C}$, o que está acima do valor recomendado por Mahoney. $\mathrm{O}$ fator solar também ultrapassa 0 limite recomendado, ficando em $6 \%$, já que a absortância da telha de barro é de 0,75.

Para reduzir a transmitância e melhorar o desempenho térmico da cobertura poderia ter sido utilizado, entre a telha e o forro, algum material refletor da radiação solar ou um material isolante térmico. 0 uso de uma lâmina de alumínio polido, por exemplo, auxiliaria na reflexão da radiação solar e reduziria a transmitância térmica para $1,1 \mathrm{~W} / \mathrm{m}^{2} \mathrm{C}$; reduziria também o fator solar para $3,3 \%$. Outra alternativa seria 0 uso de 2,5cm de lã de vidro sobre o forro de madeira, que diminuiria a transmitância para $0,95 \mathrm{~W} / \mathrm{m}^{2} \mathrm{C}$. A telha de barro é um material que possui inércia térmica relativamente elevada -0 valor do produto $\lambda c p$ (condutividade térmica, calor específico e massa específica) é de $380 \mathrm{kcal} / 2 / \mathrm{m}^{4} \mathrm{~h}^{\circ} \mathrm{C}$ (ALUCCI, 1981). Por isso, uma superfície de maior refletância auxilia no melhor desempenho térmico do ambiente interno, como o uso de telhas com superfície externa de cor clara, por exemplo.

Para as paredes, Mahoney recomenda o uso de materiais leves (com baixa inércia térmica) e refletores, com transmitância térmica de no máximo $2,8 \mathrm{~W} / \mathrm{m}^{2}{ }^{\circ} \mathrm{C}$ e fator de calor solar igual ou inferior a 4\%. Na casa-lar, as paredes são de tijolos cerâmicos com furos, rebocados em ambas as faces, com espessura total de $15 \mathrm{~cm}$, cuja transmitância é de $2,38 \mathrm{~W} / \mathrm{m}^{2}{ }^{\circ} \mathrm{C}$. A cor externa da casa analisada é verde claro, que possui uma absortância de 0,4 e um fator solar de 3,8\%. Os valores obtidos estão dentro dos 
limites indicados. Entretanto, se a casa fosse pintada de branco, cor indicada no projeto original e presente em diversas outras casas da Aldeia, o fator solar cairia para 1,9\%, melhorando ainda mais 0 desempenho térmico da construção.

A análise dos materiais construtivos, aqui empreendida, auxilia na leitura dos dados obtidos na pesquisa de campo e na verificação dos resultados obtidos. A inércia térmica identificada nas medições está dentro do apropriado ao clima quente e úmido, o que pôde ser confirmado pelo cálculo de transmitância térmica das paredes, e auxilia na redução da variação da temperatura interna, como mostrou a pesquisa de campo. Assim sendo, o monitoramento de temperatura e umidade, juntamente com os cálculos acima efetuados, comprovam a escolha adequada dos materiais das vedações laterais. A cobertura, entretanto, deveria ser melhor isolada termicamente, pois sua resistência térmica está abaixo do valor necessário para a região.

Algo importante a salientar é o fato de que as medições foram realizadas em um período de temperaturas mais amenas na região, e seria de grande interesse a realização de um monitoramento também no período considerado crítico quanto ao conforto térmico, entre os meses de julho e outubro. No próximo item são analisadas as aberturas projetadas para ventilação natural, que constituem o elemento de maior refinamento projetual da casa-lar e grande destaque desta obra.

\subsubsection{Análise de ventilação natural}

Dentre as três obras analisadas, esta é a que apresenta as características mais favoráveis à ocorrência de ventilação natural, tanto pelas estratégias de projeto adotadas como principalmente pelos fatores externos. O conjunto está implantado em sítio de altitude mais elevada, uma área de desnível relativamente acentuado e vegetação rasteira. $O$ entorno também não apresenta muitas construções ou vegetação densa, que poderiam funcionar como barreira ao fluxo de ar, como ocorre na Universidade. As edificações são bastante afastadas umas das outras e estão implantadas em diferentes patamares, ficando mais expostas, assim, aos ventos dominantes da região, que são suficientes para prover uma ventilação natural adequada, como pôde ser comprovado pelo monitoramento de velocidade do ar. No projeto da casa-lar, o arquiteto utiliza diversas estratégias de ventilação e diferentes tipos de aberturas, no intuito de manter todo o ambiente interno sempre permeável às brisas.

As análises empreendidas neste edifício permitiram verificar a real eficácia das estratégias propostas e identificar alguns elementos desfavoráveis à ocorrência da ventilação natural. A sala, ambiente com 
dimensões de $6,8 \mathrm{~m}$ por $5,5 \mathrm{~m}$, possui aberturas de saída do ar ligeiramente maiores do que as aberturas de entrada (fachada Norte possui $5,3 \mathrm{~m}^{2}$ de área de abertura e fachada Sul possui $6,8 \mathrm{~m}^{2}$ ), 0 que é recomendado por Mahoney, para otimizar a velocidade do ar no interior dos ambientes. Entretanto, a ampliação da área de serviço ao lado da cozinha (fachada Norte), realizada a pedido dos moradores, criou um elemento que funciona como barreira aos ventos dominantes locais, que possuem direção Nordeste. Como o muro é constituído por elementos vazados, o fluxo de ar chega a atravessálo, porém perde sua força e atinge apenas parcialmente as aberturas de entrada do ar, como pode ser observado na figura 10.45, a seguir. As medições de velocidade do ar efetuadas no local acusaram uma velocidade de 2 a 3,5m/s para o ponto externo (ponto 4), enquanto o ponto interno, situado ao lado da abertura da fachada Norte (ponto 2), obteve uma velocidade média de apenas $0,33 \mathrm{~m} / \mathrm{s}$.

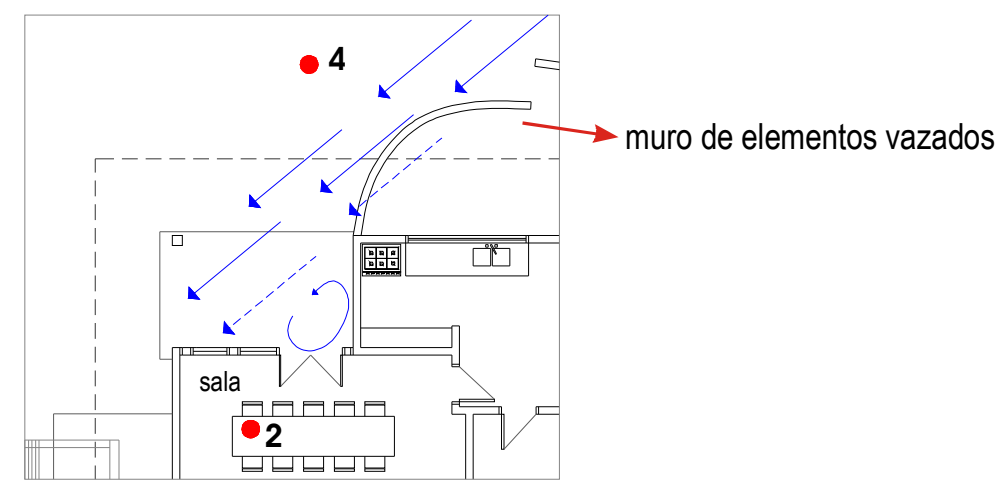

Figura 10.45: Esquema de fluxo de ar - fachada Norte da casa-lar

A média de velocidade do ar obtida para a sala foi de $0,25 \mathrm{~m} / \mathrm{s}$, que provoca um efeito imperceptível no homem, segundo Olgyay (1998) e Evans (1957 apud FREIXANET; VIQUEIRA, 2004). Este resultado se deve, em grande parte, ao fato das esquadrias da sala estarem apenas com as venezianas móveis abertas, opção de uso dos próprios moradores. Esta velocidade provoca um efeito de esfriamento no homem de cerca de $0,7^{\circ} \mathrm{C}$ (Borel, 1967).

As medições realizadas no eixo de circulação central da casa também acusaram baixas velocidades do ar: próximo à entrada (fachada Leste) a velocidade média foi de $0,42 \mathrm{~m} / \mathrm{s}$ e próximo à saída (fachada Oeste) a velocidade média ficou em $0,27 \mathrm{~m} / \mathrm{s}$. No entanto, um desempenho melhor era esperado, já que este eixo deveria constituir um percurso de circulação do ar, como foi visto na análise qualitativa.

Algumas razões para o resultado obtido podem ser encontradas: a esquadria localizada na fachada Oeste, que funciona como abertura de saída do ar, encontrava-se, durante as medições, com suas folhas pivotantes fechadas, e apenas as venezianas abertas, o que reduziu consideravelmente a área 
para circulação do ar; os elementos vazados da fachada Leste, que constituem a abertura de entrada do ar, estão mal posicionados em relação aos ventos dominantes locais (figura 10.46). Um ligeiro deslocamento da parede do quarto (ou dos próprios elementos vazados) poderia aumentar o fluxo de ar que penetra por esta abertura, como pode ser visto nas figuras seguintes:
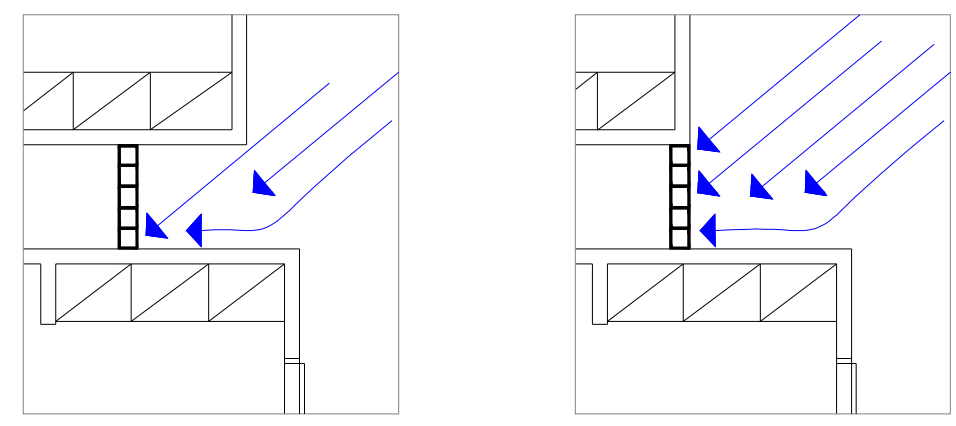

Figuras 10.46 e 10.47: Abertura de elementos vazados - como é hoje e proposta de mudança

O quarto analisado (fachadas Leste/Sul) possui dimensões de 5,6m por 3,7m. As aberturas de entrada do ar possuem uma área total de 2,94m² e estão localizadas na fachada Leste, com exposição direta aos ventos dominantes locais. As aberturas de saída do ar são compostas por uma esquadria localizada na fachada Sul e por um rasgo no forro, somando uma área total de $0,8 \mathrm{~m}^{2}$. Através destes dados já se pode apontar alguns fatores desfavoráveis à ocorrência de ventilação cruzada. $A$ área de saída do ar é consideravelmente menor do que a de entrada, enquanto que, para o bom funcionamento da ventilação cruzada, recomenda-se que as áreas de entrada e saída sejam semelhantes, ou que a saída seja ligeiramente maior. As aberturas de entrada e saída do ar estão localizadas em paredes adjacentes, uma vez que, quando o vento incide obliquamente, a disposição das janelas em paredes opostas resulta em uma melhor distribuição do ar no ambiente interno.

Neste quarto, existe área suficiente na fachada Sul para que haja aberturas de saída do ar mais generosas, o que poderia contribuir para um aumento na ventilação cruzada do ambiente. Ou inclusive na fachada Oeste, que apesar de possuir orientação desfavorável, está bem protegida pelo beiral. Já a abertura no forro, por sua reduzida dimensão e pequena diferença de altura em relação à abertura de entrada do ar, pouco contribui para a ventilação do ambiente. Na pesquisa de campo pôde-se observar que não havia fluxo ascendente de ar. 


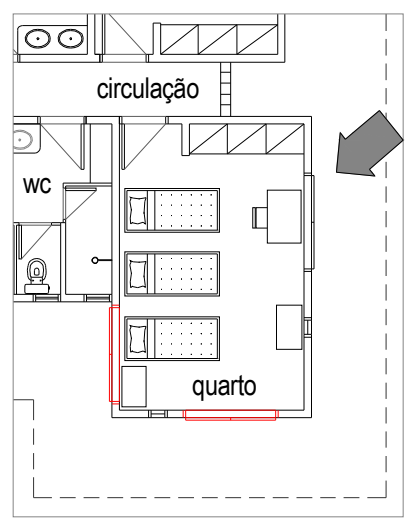

Figura 10.48: Possíveis opções para aberturas de saída do ar, em destaque

Os dados aqui apontados justificam o desempenho insuficiente apresentado por este ambiente durante 0 monitoramento de velocidade do ar. Entretanto, outro fator que contribui em grande parte para 0 resultado apresentado está na forma de apropriação do espaço pelos moradores. A disposição de alguns móveis pode atrapalhar o uso correto das estratégias projetadas pelo arquiteto, como, por exemplo, a estante disposta em frente à esquadria de entrada de ar, que por este motivo não pode ser aberta (figura 10.49). Além disso, a esquadria de correr, situada na fachada Leste, estava fechada durante todo o período de monitoramento, apenas com as venezianas abertas, como mostra a imagem seguinte, à esquerda.

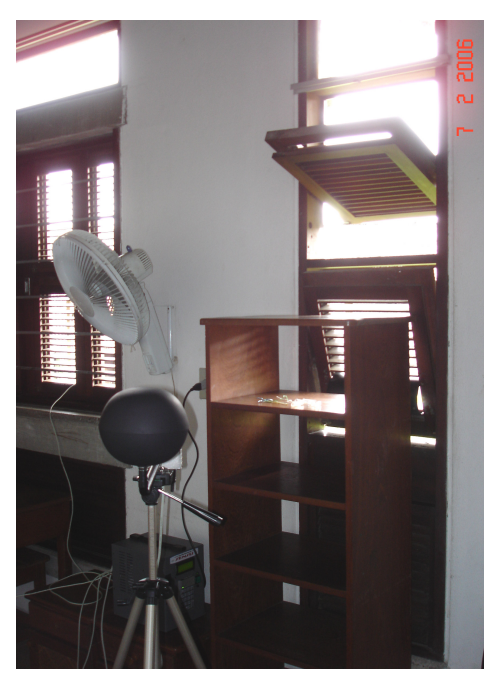

Figura 10.49: Estante em frente à esquadria impede sua abertura

Neste quarto, a largura das aberturas de entrada do ar compõe cerca de 2/3 da largura da parede, e da 
abertura de saída cerca de 1/3. De acordo com Givoni (1976), para esta situação seria esperado um fluxo de ar médio em torno de $36 \%$ em relação ao vento externo disponível, para vento oblíquo e janelas em paredes adjacentes. Se as aberturas estivessem em paredes opostas, 0 aproveitamento subiria para 43\%. Porém, com a situação encontrada durante as medições, o resultado obtido foi uma média de apenas $17 \%$ de aproveitamento do vento, já que as esquadrias fechadas resultaram em uma área de abertura consideravelmente menor. A velocidade média interna foi de $0,23 \mathrm{~m} / \mathrm{s}$, o que não provoca nenhum efeito sobre o homem, segundo Olgyay (1998) e Evans (1957 apud FREIXANET; VIQUEIRA, 2004).

\subsubsection{Considerações finais}

O projeto das Aldeias Infantis é, dentre as três obras analisadas, o que melhor exemplifica a aplicação de conceitos regionais e bioclimáticos presentes na discussão sobre a obra de Severiano Porto. Utiliza elementos regionais como o chapéu de palha, que integra as obras do conjunto e cria a relação de vizinhança desejada para a Aldeia. Usa materiais adequados ao clima e presentes na região, como a madeira e a palha. Faz bom uso do sítio de intervenção, ao implantar os edifícios de forma a melhor aproveitarem os ventos dominantes da região e ao mesmo tempo não ficarem vulneráveis à radiação solar direta.

As casas-lares apresentam elementos construtivos característicos da região, como os beirais amplos, que protegem as vedações laterais contra as chuvas e a incidência direta da radiação solar; as varandas, que constituem espaços de transição entre o ambiente externo e o interno; o pergolado de madeira, que protege a fachada de orientação menos favorável; os elementos vazados e muxarabis, que permitem fluxo de ar constante. Todos estes elementos projetuais visam contribuir para 0 desempenho térmico da edificação, e muitas destas estratégias estão presentes nas recomendações de Mahoney para a região.

As estratégias adotadas para ventilação natural também mostram soluções ricas em detalhes que justificam a singularidade da obra de Severiano Porto, pois raramente se encontram edificações na região com tais preocupações tão evidenciadas. As esquadrias possuem sistemas de abertura a diferentes alturas, de diferentes formas de funcionamento, fixas ou ajustáveis; os elementos vazados, em concreto ou madeira, são utilizados de forma a permitirem um fluxo de ar constante; as venezianas fixas sobre as portas ajudam a manter todos os ambientes da casa ventilados. No entanto, os resultados da pesquisa de campo acusaram um baixo aproveitamento do vento externo disponível e 
uma ventilação interna fraca.

Grande responsabilidade para este resultado está nos próprios usuários da edificação, que fazem mau uso das estratégias fornecidas pelo arquiteto. Durante a pesquisa de campo, tanto o quarto monitorado como os demais quartos da casa estavam constantemente com as esquadrias fechadas, apenas as venezianas horizontais estavam abertas. A esquadria de correr do quarto monitorado encontrava-se inclusive trancada com cadeado, o que indica a falta de costume em abri-la. Na sala, a situação encontrada foi a mesma, sendo que, em algumas visitas realizadas, as esquadrias estavam fechadas $e$ o ventilador ligado. Ao invés de aproveitar-se da brisa natural para condicionamento térmico, os moradores fazem uso de um equipamento elétrico, causando um dispêndio desnecessário de energia.

Em ambientes naturalmente ventilados, o papel dos usuários é de fundamental importância para 0 desempenho térmico da edificação, pois depende deles a adequada utilização dos meios de controle, como abrir janelas, fechar cortinas, apagar as luzes, entre outros.

O ganho térmico solar faz com que em edificações naturalmente ventiladas, a temperatura média interna seja superior à temperatura média externa. Este calor excedente poderia ser retirado pelo uso da ventilação, mas a temperatura interna nunca seria inferior à externa. Por isso, em edificações naturalmente ventiladas, os ocupantes têm um importante papel no gerenciamento do clima interno. (PAPST et al, 2001)

Contudo, pode-se observar que não se encontram aparelhos de ar condicionado nas edificações da Aldeia. A própria moradora da casa analisada, a mãe Lúcia, afirmou que a edificação é bem arejada e confortável, e não há necessidade de refrigeração artificial, mesmo nas épocas mais quentes do ano. Isto mostra que em edificações de classes mais pobres, onde não há uso do ar condicionado, a tolerância à variação de temperatura dos usuários pode ser maior do que em locais onde os ocupantes estão acostumados a equipamentos de refrigeração artificial, como é o caso da Universidade, por exemplo. Em casos como a Aldeia, a aceitação às estratégias de climatização natural é maior, e as condições naturais não impedem a obtenção de ambientes confortáveis. 


\section{CONCLUSÕES}

A arquitetura amazonense de Severiano Porto procura ser coerente, de uma maneira geral, com as respostas básicas que se espera de um projeto no clima quente e úmido. $\mathrm{O}$ arquiteto estuda e utiliza diferentes soluções de caráter bioclimático em seus projetos, o que pode ser observado pela preocupação em contextualizar o edifício com o sítio e seu entorno; pela definição da implantação de acordo com a trajetória solar e os ventos dominantes locais; pela presença regular de elementos construtivos característicos para controle da incidência solar, como beirais amplos, varandas e áreas de circulação cobertas, brises, pergolados, elementos vazados, entre outros.

As soluções arquitetônicas encontradas em suas obras em Manaus se destacam pela evidente preocupação em abordar estratégias para prover ventilação natural. 0 arquiteto conhece o fenômeno conceitualmente e procura incorporá-lo em seus projetos das mais diversas formas. Ao examinar tais estratégias projetuais em suas obras, pôde-se evidenciar sua preocupação com 0 tema dentro da arquitetura brasileira e a contribuição destas soluções para o melhor relacionamento do ambiente construído com o meio.

As três obras escolhidas para esta pesquisa exemplificam traços marcantes do trabalho do arquiteto: a escolha dos materiais e sistema construtivo como conseqüência das necessidades da proposta e do programa; a procura pela adequação à paisagem do entorno como meio de minimizar o impacto da intervenção; o trabalho cuidadoso nas questões de conforto térmico, cada obra à sua maneira; a atenção especial dada aos ventos dominantes locais e a freqüente utilização de ventilação cruzada associada ao efeito chaminé. A análise empreendida nas três obras deixou clara a atenção primordial que 0 arquiteto dá à questão da ventilação natural. As estratégias identificadas foram:

Tabela 11.1 - Estratégias de ventilação natural identificadas nas obras de Severiano Porto

\begin{tabular}{|c|l|}
\hline \multirow{5}{*}{ Ventilação cruzada } & aberturas localizadas nas zonas de alta e baixa pressão \\
\cline { 2 - 2 } & fluxo de ar direcionado à zona ocupada do ambiente \\
\cline { 2 - 2 } & elementos vazados, muxarabis e venezianas fixas para circulação constante de ar \\
\cline { 2 - 2 } & $\begin{array}{l}\text { aberturas localizadas a diferentes alturas, permitindo variabilidade no } \\
\text { direcionamento do fluxo de ar }\end{array}$ \\
\cline { 2 - 2 } & $\begin{array}{l}\text { esquadrias com } 100 \% \text { de área real de abertura (folhas pivotantes, de correr ou de } \\
\text { dobradiça) }\end{array}$ \\
\cline { 2 - 2 } & esquadrias que permitem direcionamento do fluxo de ar (venezianas reguláveis) \\
\hline \multirow{3}{*}{ Efeito chaminé } & aberturas na cobertura para saída do ar aquecido \\
\cline { 2 - 2 } & aberturas no forro ou na laje para saída do ar aquecido \\
\cline { 2 - 2 } & colchão de ar ventilado entre forro e cobertura \\
\hline
\end{tabular}


Nem todas as estratégias utilizadas pelo arquiteto mostraram-se adequadas ou apresentaram funcionamento satisfatório, pois seu emprego nas obras é algo bastante experimental. De forma geral, para que as estratégias propostas por Severiano funcionassem adequadamente, não bastaria ser empírico. A consulta a um especialista da área seria fundamental para garantir o emprego de relações geométricas/ matemáticas corretas, como o dimensionamento das aberturas, as distâncias entre elas, 0 melhor posicionamento, etc. Entretanto, seus projetos abordam os conceitos básicos de ventilação natural de uma forma que, sem dúvida, não se encontra na maioria dos edifícios da região, e a preocupação de Porto com tais questões é acima de tudo louvável.

Vale ressaltar, neste momento, as estratégias que deram certo e as que não deram, nas três obras analisadas, como forma de realizar um balanço final do que foi abordado. Quanto às estratégias utilizadas para ventilação cruzada, tanto a Universidade como as Aldeias apresentam premissas projetuais apropriadas. Pode-se observar o cuidado na disposição de aberturas nas zonas de alta e baixa pressão, o correto posicionamento das aberturas em relação à zona de atividade dos ambientes, além do trabalho refinado no projeto de esquadrias, que apresentam bons sistemas de funcionamento e permitem direcionamento do fluxo de ar. Há, no entanto, alguns fatores desfavoráveis quanto ao dimensionamento e posicionamento de algumas esquadrias, principalmente no projeto das Aldeias, que interferem no funcionamento da ventilação cruzada. $O$ edifício da Suframa foi o único que apresentou uma abordagem problemática desta estratégia, tanto pela distribuição dos espaços em planta como pela escolha dos tipos de esquadrias.

Porto mostra uma grande preocupação em adotar a ventilação por efeito chaminé, demonstrando conhecer a importância desta estratégia para a cidade de Manaus, devido aos ventos de baixa velocidade. No entanto, a estratégia não funciona de forma apropriada em nenhuma das três obras analisadas. Tanto na Universidade como nas Aldeias a diferença de altura entre as aberturas de entrada e saída do ar é um fator limitante, pois não permite a criação de um gradiente de temperatura adequado, dificultando a ocorrência do movimento de ar. Neste caso, um fator que poderia compensar a altura insuficiente seria a existência de uma diferença considerável de temperatura entre os ambientes interno e externo. Como isto não ocorre neste clima, a ventilação por diferença de temperatura, nestes dois edifícios, é muito pequena para ter alguma aplicação prática. Este tipo de movimento de ar só poderia ter bom funcionamento na Suframa, que apresenta uma diferença de altura razoável entre as aberturas e um bom gradiente de temperatura, como pôde ser observado na análise quantitativa. Neste edifício, contudo, o grande problema está na abertura de saída do ar localizada na coifa, que possui tamanho excessivamente reduzido. 
Em clima quente e úmido, uma importante estratégia para utilização do efeito chaminé é a criação de um gradiente de temperatura favorável ao movimento do ar. A captação do vento por entradas subterrâneas, como o arquiteto João Filgueiras Lima (Lelé) utiliza em edifícios hospitalares, é uma alternativa para redução da temperatura do ar na abertura de entrada, por exemplo. Pode-se também recorrer ao aumento da temperatura na abertura de saída, se o pé-direito do edifício for suficiente para evitar o aquecimento da zona habitada. Uma alternativa para este tipo de solução seria a pintura da cobertura de uma cor escura, para aumentar sua absortância à radiação solar.

Um problema identificado no decorrer da pesquisa, que está além do domínio do arquiteto, é a ignorância por parte de alguns usuários sobre as estratégias corretas que deveriam ser adotadas para tirar melhor proveito possível da ventilação natural. O usuário deveria ser informado sobre como utilizar os mecanismos existentes, estar ciente de tanto suas vantagens como dos inconvenientes que possam ocorrer junto. Apresenta-se aqui um problema de conscientização dos usuários, onde também entra a questão do uso excessivo do ar condicionado. A ventilação natural e outros meios para obtenção de conforto têm sido relegados após a aparição de sistemas artificiais de climatização e ventilação mecânica. As pessoas estão se tornando "viciadas" em ar condicionado, e por isso acabam reduzindo sua aceitação ao calor e utilizando sistemas mecânicos mesmo em períodos que são desnecessários. Este problema foi identificado em duas das três obras analisadas, onde o padrão sócio-econômico dos ocupantes permite a incorporação destes elementos.

O tema de pesquisa abordado - ventilação natural - ainda é pouco aprofundado para o clima tropical quente e úmido brasileiro, como pôde ser observado na revisão bibliográfica, em que a maioria de dados encontrados foi em publicações internacionais. É de extrema importância a ampliação e divulgação do conhecimento científico na área, visando maior aplicabilidade destes conceitos pelos arquitetos em atuação e maior conscientização dos usuários da necessidade de utilização de forma apropriada das estratégias presentes. Isto torna de grande importância a continuidade desta pesquisa, e alguns indicativos são apresentados no item a seguir.

\subsection{PROPOSTAS PARA TRABALHOS FUTUROS}

A compilação de imagens de 12 obras de Severiano Porto ${ }^{29}$, realizada a partir do material obtido em seu acervo (NPD-UFRJ), fornece subsídios para outros estudos. O material foi organizado em CD e pretende-se divulgá-lo em bibliotecas e sites da internet, permitindo fácil acesso e consulta. Isto

29 Ver Anexo 13.2. 
possibilita a análise de outras obras do arquiteto, inclusive enfocando outros aspectos também de grande importância, como, por exemplo, um estudo mais aprofundado dos mecanismos de controle da radiação solar, um estudo de iluminação natural, etc.

Como possibilidades de aprofundamento desta pesquisa, as medições da pesquisa de campo poderiam ser refeitas em um período mais crítico quanto ao conforto térmico - entre os meses de julho e outubro, inclusive com a possibilidade de monitoramento da temperatura radiante, para uma verificação mais detalhada do comportamento térmico da edificação. Outras abordagens ao tema poderiam ser trabalhadas, como a verificação de eficiência das estratégias através de simulação computacional aliada à simulação em túnel de vento, onde haveria possibilidade de simulação de alternativas e propostas de funcionamento. Trabalhos futuros também poderiam abordar a sensação térmica, como complemento às análises, através de avaliação subjetiva dos usuários dos edifícios. 


\section{REFERÊNCIAS}

A NATUREZA é nosso maior argumento. (1983). 0 Turista, [s.I.], n.11, p.14, nov.

ACAYABA, M.M.; FICHER, S. (1979). Arquitetura brasileira: tendências atuais. Projeto, São Paulo, n. 16, p.23-30, nov.

ADAM, R.S. (2001). Princípios do ecoedifício - interação entre ecologia, consciência e edifício. São Paulo: Aquariana.

ALLARD, F. (Ed.). (1998). Natural ventilation in buildings - a design handbook. London: James \& James.

ALUCCI, M.P. (1981). Recomendações para adequação de uma edificação ao clima, no estado de

São Paulo. 2v. Tese (Doutorado) - Faculdade de Arquitetura e Urbanismo, Universidade de São Paulo, São Paulo, 1981.

AMERICAN SOCIETY OF HEATING, REFRIGERATING AND AIR CONDITIONING ENGINEERS (2004). ANSI/ASHRAE 55-2004 - Thermal environmental conditions for human occupancy. Atlanta.

ARENS, E.A.; BLYHOLDER, A.G.; SCHILLER, G.E. (1984). Predicting thermal comfort of people in naturally ventilated buildings. ASHRAE Transactions; Atlanta, v.90, n.1B, p.272-284.

ARQUITECTURA en Iberoamérica: algunas reflexiones sobre la arquitectura. (1985). Summa, Buenos Aires, n.212, p.54, mayo.

ARQUITETOS de várias gerações mostram o que pensam. (1990). Projeto, São Paulo, n.129, p.168178.

ARQUITETURA: uma casa em Manaus. (1972). Casa e Jardim, São Paulo, n.210, p.20-31, jul.

AsBEA. Catálogo. [200-?]. São Paulo: AsBEA. p.70-73.

ASHLEY, S.; SHERMAN, M. (1984). The calculation of natural ventilation and comfort. ASHRAE Transactions, Atlanta, v.90, n. 1B, p.253-271.

ASSOCIAÇÃO BRASILEIRA DE NORMAS TÉCNICAS - ABNT. NBR 15220 - Desempenho térmico de edificações. Rio de Janeiro: ABNT, set. 2003.

AWBI, H.B. (1995). Ventilation of buildings. London: E \& FN Spon.

BALBINA. (1996). Arquitectura Panamericana, Brasília, n.4, p.96, maio. 
BASTOS, M.A.J. (2003). Pós-Brasília: rumos da arquitetura brasileira. São Paulo: Perspectiva; FAPESP.

BITTENCOURT, L.S. (1995). Comparando os programas Breeze e Easyflow como instrumentos de simulação da ventilação natural. In: ENCONTRO NACIONAL DE MODELOS DE SIMULAÇÃO DE AMBIENTES, 1995, São Paulo. Modelos de Simulação de Ambientes. São Paulo: NUTAU/USP.

BITTENCOURT, L. S.; CÂNDIDO, C. (2005). Introdução à ventilação natural. Maceió: EDUFAL.

BITTENCOURT, L. S.; CÂNDIDO, C.; BATISTA, J.O. (2003). A utilização de captadores de vento para aumentar a ventilação natural em espaços de sala de aula. In: ENCONTRO NACIONAL SOBRE CONFORTO NO AMBIENTE CONSTRUÍDO, 7., 2003, Curitiba. Anais... Curitiba: ANTAC. CD-ROM. BOREL, J.C. (1967). Confort thermique en climat chaud. São Paulo: FAU/USP.

BOUTET, T.S. (1987). Controlling air movement: a manual for architects and builders. New York: Mc-Graw Hill Book.

BRAZIL: the Amazon. (1977). Home - Los Angeles Times, Los Angeles, 27 feb. p.12-13.

BRUAND, Y. (1997). Arquitetura contemporânea no Brasil. Tradução de Ana M.Goldberger. 3.ed. São Paulo: Perspectiva.

CAMOUS, R.; WATSON, D. (1986). El habitat bioclimático: de la concepción a la construcción. Barcelona: Gustavo Gili.

CAMPOS, E.R. (2003). A arquitetura brasileira de Severiano Mário Porto. Arquitextos, 209, dez. Disponível em:<www.vitruvius.com.br/arquitextos/arq000/ esp209.asp>. Acesso em: 10 mar. 2004.

CAMPUS da Universidade do Amazonas, Manaus, AM. (1991). Cadernos Brasileiros de Arquitetura, São Paulo, n.20, p.18-23.

CASA Porto, Manaos, Brasil. (1979) Summa, Buenos Aires, n.133, p.41-44, febrero.

CASTRO FILHO, J.P. (1984). Estudo sobre exemplos de arquitetura tropical, erudita e suas adequações à Amazônia brasileira no último decênio. 272p. Dissertação (Mestrado) - Escola de Engenharia de São Carlos, Universidade de São Paulo, São Carlos, 1984.

CATÁLOGO de exposição arquitetos brasileiros. (1987). Paris.

CAUDILL, W.W. (1951). Some general considerations in the natural ventilation of buildings. Texas: Texas Engineering Experiment Station.

COLONNE indigene. (1977). Ville Giardini, Milano, n.109, p.18-21, fev. 
COOK, J. (1989). The state of passive cooling research. Cambridge: MIT Press.

CORBELLA, O.; YANNAS, S. (2003). Em busca de uma arquitetura sustentável para os trópicos conforto ambiental. Rio de Janeiro: Revan.

COSTA, E.C. (1982). Arquitetura ecológica: condicionamento térmico natural. São Paulo: Edgard Blücher.

CZAJKOWSKI, J. (1976). Uma arquitetura para a Amazônia. Jornal Mensal de Artes Visuais GAM, Rio de Janeiro, n.27, p.14-15, maio.

É PRECISO sacudir a poeira, criticar, discutir, se encontrar. (1982). Projeto, São Paulo, n.42, p.78-87. Edição especial.

ECOLOARQUITETURA. (1978). Veja, São Paulo, n.538, p.48, dez.

EM DEBATE, a crise dos anos 80 e tendências da nova década. (1990). Projeto, São Paulo, n.129, p.143-157, jan./fev.

ESTE homem planta casas como quem planta uma flor. (1981) Cláudia, São Paulo, n.232, p.102-103, jan.

FANGER, P.O. (1987). Airflow characteristics in the occupied zone of ventilated spaces. ASHRAE Transactions, Atlanta, v.93, parte 1.

FICHER, S.; ACAYABA, M.M. (1982). Arquitetura moderna brasileira. São Paulo: Projeto.

FREIXANET, V.A.F. (2004). Clima y arquitectura. México: UAM.

(2005). Ventilación y confort. Azcapotzalco: Universidad Autónoma Metropolitana; CyAD; Departamento de Medio Ambiente; Laboratorio de Investigaciones en Arquitectura Bioclimática.

FREIXANET, V.A.F.; VIQUEIRA, M.R. (2004). Ventilación natural: cálculos básicos para arquitectura. México: UAM.

FROTA, A.B.; SCHIFFER, S.R. (1995). Manual de conforto térmico. 2.ed. São Paulo: Studio Nobel. GAGLIARDI, V.B. (1968). Arquitetura brasileira do ano. ABA - GB, Rio de Janeiro, p.80-125.

GARCÍA, R.; FUENTES, V. (2005). Viento y arquitectura. México: Trillas.

GIVONI, B. (1962). Basic study of ventilation problems in housing in hot countries. Israel: Building Research Station Technion. Report of the Israel Institute of Technology. . (1976). Man, climate and architecture. Londres: Applied Science. (1994). Passive and low energy cooling of buildings. Nova York: Van Nostrand Reinhold. 
GOMES, L. (1985). O artista da Amazônia. Veja, São Paulo, n.851, p.118-120, jul.

GOMES, R.J. (1967). Problema do conforto térmico em climas tropicais e subtropicais. Lisboa: LNEC.

HESPANHA, S. (2005). Entre o regional e o moderno. AU, São Paulo, n.130, p.53-59, jan.

INSTITUTO DE ARQUITETOS DO BRASIL (1984). Primeira mostra de trabalhos de arquitetos de Manaus. São Paulo: IAB, Departamento Amazonas.

INTEGRAÇÃO com a natureza define o projeto. (1985). Dirigente Construtor, São Paulo, n.9, p.5861 , set.

IZARD, J.L.; GUYOT, A. (1983). A arquitetura bioclimática. México: Gustavo Gili.

JUSTIÇA de Manaus vai mudar para casa nova. (1979). A Construção Norte Nordeste, São Paulo, n.74, p.6, jul.

KOENIGSBERGER, O.H. INGERSOLL, T. G.; MAYHEW, A.; SZOKOLAY, S. V. (1973). Manual of tropical housing and building. Londres: Longman.

. (1977). Viviendas y edificios en zonas cálidas y tropicales. Madrid: Paraninfo.

LAMBERTS, R.; DUTRA, L.; PEREIRA, F.O.R. (1997). Eficiência energética na arquitetura. São Paulo: PW.

LECHNER, N. (1991). Heating, cooling, lighting: design methods for architects. New York: John Wiley.

LEE, K.M. (1998). Severiano Mário Porto: a produção do espaço na Amazônia. 151p. Dissertação (Mestrado) - Faculdade de Arquitetura e Urbanismo, Universidade de São Paulo, São Paulo, 1998.

LOUREIRO, K.; CARLO, J.C.; LAMBERTS, R. (2002). Estudos de estratégias bioclimáticas para a cidade de Manaus. In: ENCONTRO NACIONAL DE TECNOLOGIA NO AMBIENTE CONSTRUÍDO, 9., 2002, Foz de Iguaçu. Anais... Foz do Iguaçu: ANTAC. CD-ROM.

MAGALHÃES, A.L.P. (1986). Severiano Mário Porto e Mário Emílio Ribeiro. In: PREMIAÇÃO ANUAL DO IAB, 24., 1986. [S.I.:S.n.].

MASCARO, L. (1977). Ventilação natural dos edifícios. São Paulo: FAU/USP.

(1991). Energia na edificação: estratégia para minimizar seu consumo. 2.ed. São Paulo: Projeto. 
MELARAGNO, M.G. (1982). Wind in architectural and environment design. New York: Van Nostrand Reinhold.

MINGA (1990). Severiano Mário Porto: un lenguaje desvinculado de estereótipos. (1990). Planta Libre, México, n.4-5, dez.

MORAES, E.M.L. (1992). A vegetação no auxílio do conforto térmico do conjunto habitacional cidade nova em Belém-PA. 113p. Dissertação (Mestrado) - Escola de Engenharia de São Carlos, Universidade de São Paulo, São Carlos, 1992.

NEVES, L. (2005). Severiano Porto: uma produção regional e uma contribuição para a arquitetura nacional. In: INTERNATIONAL WORKING PARTY FOR DOCUMENTATION AND CONSERVATION OF BUILDING, SITES AND NEITHBORHOODS OF THE MODERN MOVEMENT (DOCOMOMO), 2005, Niterói-RJ. Proceedings... [S.I.:S.n.]. CD-ROM.

(2006a). A arquitetura de Severiano Porto sob enfoque bioclimático: ventilação natural no campus da Universidade do Amazonas, Manaus-AM. In: ENCONTRO NACIONAL DE TECNOLOGIA NO AMBIENTE CONSTRUÍDO, 11., 2006, Florianópolis. Anais... Florianópolis: ANTAC. CD-ROM.

(2006b). Architecture integrated to nature: the use of timber by Severiano Porto in Brazilian Amazon. In: CONFERENCE ON PASSIVE AND LOW ENERGY ARCHITECTURE, 23., 2006, Genebra. Proceedings... Genebra: s.n.

NEVES, L.; CARAM, R. (2005). Arquitetura bioclimática e a obra de Severiano Porto. In: ENCONTRO NACIONAL DE CONFORTO NO AMBIENTE CONSTRUÍDO, 7., 2005, Maceió. Anais... Maceió: ANTAC; UFAL. CD-ROM.

OLGYAY, V. (1998). Arquitectura y clima - manual de diseño bioclimático para arquitectos y urbanistas. Barcelona: Gustavo Gili.

OLIVEIRA, F.M. (1997). A prática projetual de janelas como recurso de controle da ventilação em ambientes internos para a região de Maceió. 1v. Dissertação (Mestrado) - Escola de Engenharia de São Carlos, Universidade de São Paulo, São Carlos, 1997.

PAPST, A.L.; LAMBERTS, R. (2001). Relacionamento da temperatura interna e externa em edificações residenciais naturalmente ventiladas. In: ENCONTRO NACIONAL SOBRE CONFORTO NO AMBIENTE CONSTRUÍDO, 6.I ENCONTRO LATINO-AMERICANO SOBRE O CONFORTO NA AMBIENTE CONSTRUÍDO, 3., 2001, São Pedro. Anais... Campinas: ANTAC. CD-ROM.

PARA o calor tropical. (1972). A Casa Cláudia, São Paulo, n.135-A, p.22-24, dez. 
PEIXOTO, L.K.O.; BITTENCOURT, L.S. (2003). Estudo da ventilação natural na UFAL através de simulação computacional. In: ENCONTRO NACIONAL SOBRE CONFORTO NO AMBIENTE CONSTRUÍDO, 7., 2003, Curitiba. Anais... Curitiba: ANTAC. CD-ROM.

PENTEADO, S.; ZEIN, R.V.; YAMASHIRO, D. (1986). A longa trajetória, da efervescência cultural do Rio a Manaus. Projeto, São Paulo, n.83, p.46-86, jan.

PERDIGÃO, A.V. (1995). Arquitetura na Amazônia: a resposta térmica do beiral quebra-sol/ quebrachuva no clima quente-úmido de Belém do Pará. In: ENCONTRO NACIONAL DE CONFORTO NO AMBIENTE CONSTRUíDO, 7., 1995, Gramado. Anais... Porto Alegre: ANTAC. CD-ROM.

PETRINA, A. (1985). Severiano Porto: arquitectura e identidad regional. Summa, Buenos Aires, n.210, p.26-31, marzo.

POLITI, R. (1989). Uma casa no meio da selva. Cláudia, São Paulo, n.328, p.104-106, jan.

PORTO, S.M. (1965a). Anexo do Palácio Rio Negro. Arquitetura, Rio de Janeiro, n.42, p.61, dez. . (1965b). Assembléia Legislativa do Estado do Amazonas. Arquitetura, Rio de Janeiro, n.42, p.60, dez.

(1965c). CAMTEL - Manaus. Arquitetura, Rio de Janeiro, n.42, p.58-59, dez.

(1965d). Escolas pré-fabricadas de madeira. Arquitetura, Rio de Janeiro, n.40, p.16, out.

(1965e). Estádio Vivaldo Lima. Arquitetura, Rio de Janeiro, n.42, p.55-57, dez.

(1965f). Secretaria de produção. Arquitetura, Rio de Janeiro, n.42, p.62-63, dez.

(1966). Estádio Vivaldo Lima. Arquitetura, Rio de Janeiro, n. 44, p. 24, fev.

(1967). Residência do arquiteto em Manaus. Arquitetura, Rio de Janeiro, n.58, p.33, abr.

(1971). Severiano Porto [entrevista]. Bom Dia, ano 1, n.3, p.30-34, 31, mar.

(1975) Amazonas: pousada na llha de Silves. Módulo, Rio de Janeiro, n.75, p.58-61.

(1978a). Campus da Universidade do Amazonas. CJ Arquitetura, Rio de Janeiro, ano 5, n.20, p.27-34.

(1978b). Hospital da Santa Casa de Misericórdia de Manaus. CJ Arquitetura, Rio de Janeiro, ano 5, n.20, p.21-24.

(1978c). Residência do arquiteto Severiano Mário Porto. CJ Arquitetura, Rio de Janeiro, ano 5, n.20, p.42-45. 
(1978d). Sede administrativa da Portobrás em Manaus. CJ Arquitetura, Rio de Janeiro, ano 5, n.20, p.36-39.

. (1978e). Superintendência da Zona Franca de Manaus. CJ Arquitetura, Rio de Janeiro, ano 5, n.20, p.40-41.

(1979a). A utilização dos recursos regionais. Projeto, São Paulo, n.15, p.19-20, set./out.

. (1979b). Residence Schuster: Tarumã, Brésil. L'Architecture d'Aujourd'Hui, Paris, n.206, p.86-87, déc.

. (1979c). Residência R.S.Tarumã-AM. Módulo, Rio de Janeiro, n.53, p.60-67, mar./abr.

(1982a). Arquitetura tropical: enfoque. Módulo, Rio de Janeiro, n.70, p.64-67, maio. Edição especial.

(1982b). Harmonia entre formas e funcionalidade no projeto da Suframa. Projeto, São Paulo, n.40, p.26-28, maio.

(1982c). Arquitetura tropical na residência de Severiano Porto, em Manaus. Projeto, São Paulo, n.40, p.22-25, maio.

. (1985). Campus de la Universidad del Amazonas, Manaos, Brasil. Summa, Buenos Aires, n.212, p.55-59, mayo.

(1987a). Balbina (centro de proteção ambiental). AU, São Paulo, ANO 3, n.11, p.53-57, abr./maio.

(1987b). Severiano Mario Porto: I'homme de l'année. L'Architecture d'Aujourd'Hui, Paris, n.251, p.10, juil.

(1991). Centro di protezione ambientale in Amazzonia. Spazio e Società, Firenze, n.56, p.3441 , out./dez.

. (1993). Reurbanização da Ponta Negra: novo projeto de Severiano Porto. Projeto, São Paulo, n.166, p.79, ago.

. (1998). Severiano Porto: abrigo natural [entrevista]. AU, São Paulo, ano 5, n.81, p.24-25, dez./jan.

(2003). Arquitetura, estrutura e construção. Transcrição de Letícia Neves. São Carlos: EESC/USP. Curso ministrado no anfiteatro Jorge Caron, São Carlos.

(2005). S.M. Porto: entrevista. [mar.2005]. Entrevistadora: Letícia Neves. 
PORTO, S.M.; RIBEIRO, M.E. (1983). Pousada na llha de Silves, Amazonas. Projeto, São Paulo, n.49, p.36-46, mar.

(1988). Campus da Universidade do Amazonas. Projeto, São Paulo, n.114, p.A-14-A-15, set.

. (1989). Centro de proteção ambiental de Balbina. Projeto, São Paulo, n.125, p.69-75, set.

PORTO, S. M. et al. (1987). Manaus (corrigindo a rota). AU, São Paulo, ano 3, n.10, p.29-39, fev./mar. PRÊMIO Marcello Roberto - habitação unifamiliar. (1971). In: PREMIAÇÃO ANUAL DO IAB GB, 9., 1971. [S.I.:S.n.].

PRIMER Seminario de Arquitectura Latinoamericana: mesa redonda. (1985). Summa, Buenos Aires, n.214, p.24-32/89, jul.

PROGRAMA NACIONAL DE CONSERVAÇÃO DE ENERGIA ELÉTRICA/ ELETROBRÁS (1989). Pesquisa nacional sobre posse de eletrodomésticos e hábitos de consumo. Rio de Janeiro: PROCEL/ELETROBRÁS. 3v.

REED, R.H. (1953). Design for natural ventilation in hot humid weather. Texas: Texas Engineering Experiment Station.

RIVERO, R. (1988). Arquitectura y clima: acondicionamento térmico natural. Montevideo: Universidad de la Republica.

ROMERO, M.A.B. et al. (1997). Técnicas e dispositivos bioclimáticos na arquitetura contemporânea: uma análise crítica. In: ENCONTRO NACIONAL DE CONFORTO NO AMBIENTE CONSTRUÍDO, 4., 1997, Salvador. Anais... Florianópolis: ANTAC. CD-ROM.

RORIZ, M. (1996). Conforto térmico em edificações: um modelo matemático e uma aplicação. 185p. Tese (Doutorado) - Faculdade de Arquitetura e Urbanismo, Universidade de São Paulo, São Paulo, 1996

(2001). Higiene do trabalho: temperatura. São Carlos: UFSCar; Departamento de Engenharia de Produção. Apostila.

ROVO, M.K.I.; OLIVEIRA, B.S. (2004). Por um regionalismo eco-eficiente: a obra de Severiano Mário Porto no Amazonas. Arquitextos, 226, mar. Disponível em: <www.vitruvius.com.br/arquitextos/ arq000/esp226.asp>. Acesso em: 20 mar. 2005.

SABBAG, H. (1985a). A casa aberta à natureza. AU, São Paulo, n.3, p.38, nov. (1985b). Na Amazônia, a valorização de recursos e elementos locais. A Construção, Rio de Janeiro, n.1972, p.14-19, nov. 
(2003). Severiano Porto e a arquitetura regional. Arquitetura Crítica, n.12, set. Disponível em:<http://www. vitruvius.com.br/ac/ ac012/ac012.asp>. Acesso em: 10 mar. 2004.

SANTAMOURIS, M.; ASIMAKOPOULOS, D. (1996). Passive cooling of buildings. Londres: James \& James.

SANTO, A.E. (2002). 0 vale amazônico no futuro do mundo. Coordenação: Elisabeth Espírito Santo. 4.ed. São Paulo: Instituto Cultural Eco-econômico Espírito Santo.

SANTOS, M.M.; FREITAS, M.A.V. (1998). Arquitetura e uso eficiente da energia elétrica em áreas urbanas da Amazônia brasileira: o caso da cidade de Manaus. In: SEMINÁRIO INTERNACIONAL NUTAU, 1998, São Paulo. Arquitetura e Urbanismo: tecnologias para o século XXI. São Paulo: NUTAU/USP. CD-ROM.

SEGAWA, H. (1989). Liberdade nas curvas e um ponto de inflexão. Projeto, São Paulo, n.125, p.76, set.

(1991). Centro di protezione ambientale in Amazzonia. Spazio e Società, Firenze, n. 56, p. 34-41, out./dez.

. (1993). Severiano Porto: la sfida dell'Amazzonia. Spazio e Società, Firenze, n.61, p.8-17, jan./mar.

(1999). Arquiteturas no Brasil: 1900-1990. 2.ed. São Paulo: Ed.Universidade de São Paulo.

SEGAWA, H.; SANTOS, C.R.; ZEIN, R.V. (Org.). (1988) Arquiteturas no Brasil: anos 80. São Paulo: Projeto.

SERRA, R. (1999). Arquitectura y climas. Barcelona: Gustavo Gili.

SEVERIANO Porto/ Mário Emílio Ribeiro. (200-?). Projeto, São Paulo, p.108. Arquitetura brasileira atual - Catálogo.

SEVERIANO Porto: o arquiteto amazônico. (1986). Sintonia, n.86, p.4-5, jul.

SILVA, V. (2004). Obra pioneira. AU, São Paulo, n.119, p.48-50, fev.

SUFRAMA. (1975). Jornal de Arquitetura IAB SAG, São Paulo, ano 3, n.20, p.6, jan.

TOLEDO, A. (1999). O lugar da arquitetura bioclimática no panorama das tendências da arquitetura moderna e contemporânea. In: ENCONTRO NACIONAL DE CONFORTO NO AMBIENTE CONSTRUÍDO, 5., 1999, Fortaleza. Anais... Fortaleza: ANTAC. CD-ROM. 
. (2001). Critérios para o dimensionamento de aberturas de ventilação natural dos edifícios. In: ENCONTRO NACIONAL DE CONFORTO NO AMBIENTE CONSTRUÍDO, 26., 2001, São Pedro. Anais... Campinas: ANTAC. CD-ROM.

TOLEDO, E. (1999). Ventilação natural das habitações. Alagoas: Edufal.

UMA RETROSPECTIVA, a partir da Projeto. (1990). Projeto, São Paulo, n.129, p.111-113.

VIANNA, N.S. (1978). Arquitetura e conforto. são Paulo: FAU/USP.

WAISMAN, M. (1990). O centro se desloca para as margens. Tradução de Anita Regina Di Marco. Projeto, São Paulo, n.129, p.73-77, jan./fev.

ZEIN, R.V. (1982a). Arquitetura brasileira: tendências atuais. Projeto, São Paulo, n.42, p.115-128, jul./ago.

(1982b). O pensamento, as críticas, os sonhos e as reivindicações dos arquitetos brasileiros.

Projeto, São Paulo, n.42, p.52-60, jul./ago.

. (1986). Um arquiteto brasileiro: Severiano Mário Porto. Projeto, São Paulo, n.83, p.44-45, jan.

(1990). No século XXI, fim das utopias ou sua realização?. Projeto, São Paulo, n.129, p.6872, jan./fev.

(2003).Título de professor honoris causa para Severiano Porto. Arquitextos, 210, dez. Disponível em:<http://www.vitruvius.com.br/arquitextos/arq000/esp210.asp>. Acesso em: 10 mar. 2004. 


\section{ANEXOS}

\subsection{TRANSCRIÇÃO DA CONVERSA COM SEVERIANO PORTO}

A seguir, encontra-se a transcrição integral da conversa com Severiano Porto, realizada no dia 30 de março de 2005 no seu escritório em Niterói-RJ, durante viagem ao Rio de Janeiro para levantamento de dados.

\section{$(\ldots)$}

Severiano: Na faculdade, as escolas eram públicas, e com isso a gente via as provas dos que estavam se formando, eram 15 dias de prova e era em cima, na cúpula. Tinham quatro salas de aula grandes na parte superior. E então a gente também via, assistia tudo, de todas as turmas.

Então, nós tínhamos essa noção. Eu nunca trabalhei em escritório de arquitetura, eu só trabalhei em construtora. Porque eu digo - arquitetura eu estou aprendendo lá na faculdade, tudo isso. Agora, nós temos que usar programas de computador hoje, e tem muitos, que ensina a fazer perspectiva, ensina a fazer isso tudo. Quer dizer, a gente tinha que conceber algo que vai se materializar. Então os mestres, as obras, os carpinteiros, os marceneiros, os pintores; a gente tinha que saber como fazia, como nivelava. As firmas que faziam as esquadrias, de alumínio, de madeira, de tudo. Tinham outro conhecimento que é fundamental, porque nós projetamos coisas em três dimensões, não é só um desenho que resolve. Você tem que sentir tudo. É como sentir a região também, o clima.

$\mathrm{Na}$ Noruega tem coisas interessantes parecidas com a gente. Eles trabalham com telha de madeira, mas são grossas, bem pontudas, para segurar a neve. Eles estão certos, eles jamais fariam as coisas como tem aqui. Lá na faculdade, no Norte da Noruega, no círculo polar ártico, eu fui entrar na universidade, lá em cima estava menos $10^{\circ} \mathrm{C}$. Quando entrei era aquela maravilha: plantas, janelas abertas, tudo, e a maior clarabóia acompanhando todos os espaços. Porque por fora é usado para consumir menos energia. E aqui no nosso caso, com esse calor, em Manaus, tem clarabóia e tem ar condicionado, que a noite toda fica um mundo de ar condicionado fabricando gelo, pra poder suportar 0 dia seguinte, e todo mundo está pagando. E quando por que não abrir.

Já na Colômbia, tem shoppings baixos, com lago no meio... Todas as lojas são refrigeradas, mas é muito simpático. E nós não usamos mais os brises. Eu daqui estou olhando lá longe, está vendo? 
(mostra algo pela janela) Aquilo ali são toldos. Isso sempre funcionou. A única coisa do toldo é que, quando esquenta, 0 ar sobe e entra em casa. Se eles fossem abertos na lateral, muito do ar quente fugiria. Tem o ministério da educação, você já foi lá? Ele é perfeito. Tem brises de um lado, verticais, e com os azuis na horizontal. Porque o sol fica na horizontal, o brise não tira a visão e joga lá pra fora. 0 que acontece? Hoje todo mundo faz pele de vidro, faz vidro, vidro, vidro... e joga uma cortina do lado de dentro. Acontece que essa cortina, quando aquecida, é o mesmo do que você colocar uma torradeira ali na tomada, porque vai esquentar aqui dentro. Aquele calor tremendo está dentro da sala, o ar condicionado não dá conta pelo menos de igualar ou eliminar o ar quente, e todo mundo está condenado pro resto da vida a ter uma conta de luz altíssima. E o que custava fazer os brises?

Já na rua Chile, tem a Petrobrás. Nas fachadas laterais tem um brise vertical, porque 0 sol nasce e se põe do outro lado, vertical. Tem uns jardins, na solução. Isto é uma solução correta. Em qualquer lugar que você vá, você vê no Sul por exemplo; aonde tem clima rigoroso, tem solução certa. Manaus já desmatou tudo, mudou a cidade, tirou a umidade, é um calor tremendo e não tem mais jeito.

Leticia: Manaus mudou muito desde que você mudou para lá até hoje.

Severiano: Mudou, mudou. Quando eu cheguei tinha 250 mil habitantes, hoje deve ter 1 milhão e 600, 1 milhão e 700, está por aí. Com o distrito industrial, explodiu, veio gente de fora, de tudo que é lugar. De todo aquele Nordeste, do interior da Amazônia, tudo foi pra lá. Fora do Sul, de São Paulo, porque as indústrias são de alta tecnologia. De modo que aquilo lá explodiu, agora as soluções, não têm nada a ver com o clima.

Leticia: Como é a questão do conforto, por lá, de uma maneira geral?

Severiano: É isso que eu falei. Tudo de vidro, as janelas, não tem aquelas que abrem em cima, basculante, só tem a de correr. Se chover, lá chove muito, você tem que fechar, e é quente. E você não tem como ventilar, porque todas as janelas fecham hermeticamente. Quer dizer, eu, por exemplo, fiz umas jardineiras, em cada andar, que funcionava como se fosse o beiral de uma casa, então eram doze andares, doze casas empilhadas. Tinha uma jardineira bonita, larga, e também escondia 0 ar condicionado, que ficava ali.

Leticia: Qual a direção dos ventos dominantes?

Severiano: Lá é Nordeste. Em Manaus é Nordeste, já em Balbina é Leste-Oeste, e é perto relativamente, eu não sei por que. E na beira do rio também tem um Sudeste, que não tem no resto de Manaus. À tarde venta ao contrário, Sudoeste. E como a gente fazia as aberturas de entrada e saída funcionou do mesmo jeito, porque a saída passou a ser entrada e a entrada passou a ser saída, é um conjunto. 
Agora isso que todo mundo fala, eu acho que é o fundamento. Você vê que o caboclo, lá do Nordeste, ele sabe quando vai chover, sabe fazer a sua casa. Os índios, têm aquele problema do rio que sobe e desce. E quando o rio desce, como em Manaus e toda aquela região... Porque tem $2000 \mathrm{~km}$ de Belém até Manaus e a altura máxima que já aconteceu em Manaus foi 29 metros acima do Atlântico a 2000 $\mathrm{km}$, quer dizer, é super horizontal, nem caimento do banheiro do box, nada, muito pior. E a mínima é 13 metros acima, depois de $2000 \mathrm{~km}$. E quando a água vai baixando você tem uma diferença de 16 metros. Como as praias são horizontais, às vezes o caboclo que está morando aqui na palafita, à medida que vai baixando vai criando uma praia, e que às vezes tem 500 metros, às vezes tem mais do que isso. Então os índios, lá de cima, caminhando no Solimões... Eles pegavam essas árvores grandes, troncos um pouco menores do que esse (aponta para a mesa circular, de cerca de $1 \mathrm{~m}$ de diâmetro), e faziam uma jangada grande, depois faziam um tablado grande, faziam a casa em uma parte dele, no final tinha a horta, porque tem que ter pimenta, tem que ter uma série de temperos, porque não tem sal, e aí à medida que a praia vai baixando ele vai puxando a casa. Às vezes, quando o rio está cheio ou já está quase, ele amarra numa árvore, e fica em um outro lugar. Então, você veja que eles saíram com uma solução inteligente porque a todo momento o rio vai chegando... Já em Manaus eles fazem outros andares que irão ficar debaixo d'água, dependendo também da subida e baixada das águas, e aí quando abaixa, eles lavam tudo, e ocupam tudo durante cerca de oito meses, seis meses.

Nós, da cidade, nós perdemos muito, eu acho que atrofiamos muito os nossos sentidos. Porque a gente olha na janela pra ver se vai chover, se vai botar um casaco, se vai levar... Já no Sul não, no Sul é rigoroso. Os gaúchos, eles põem equipamentos, equipamentos que esquentam no inverno, que esfriam no verão. Se tiver que botar orientação, eles vão botar para o sol do inverno. Porque o verão é muito quente, tem outra orientação. $E$ isso é uma das coisas. Fala um pouco você.

Leticia: Meu estudo é em conforto ambiental...

Severiano: Eu estava conversando com um dentista, e há muitos anos que ele é dentista, ele é espetacular. E volta e meia ele vai mudando o consultório. E você veja que hoje tem equipamentos e produções tremendas. E quando acaba de fazer o novo consultório, já está obsoleto. Porque já tem mais na frente. Este é o nosso caso. Como é na medicina, o que surge de antibiótico, de remédio de todo tipo. Aqui, você não pode se entusiasmar com isso, você tem que aceitar o chá de erva doce, quando for o caso, e usar o de última geração, quando for o caso. Como nós, por exemplo, nós, se formos depender do cliente... O pai saía com a mulher desse médico que receitou o chá de erva doce, e ia pra outro. Só acredita em antibiótico.

$(\ldots)$ 
Então, não adianta se entusiasmar também com isso. (...) Cada dia tem algo novo. 0 que falam hoje dos alunos, que vão para o computador, as pessoas também muitas vezes não têm experiência profissional. O professor, então, também não tem o que transmitir. Também não leva os alunos para as obras, eu levava meus alunos todos. Quando entrei para dar aula, em 92, na engenharia, em Manaus...

Leticia: Não tem curso de arquitetura lá?

Severiano: Tem particular, não na federal. Faz tempo que fizemos uma programação, nós reunimos uns 20 e poucos colegas, toda noite a gente escrevia um programa da faculdade, inclusive com esse detalhe vertical, que foi o meu caso, eu ia assistir todas as provas de todos os anos, você tinha uma noção vertical de tudo. Então nós fizemos o seguinte, de dois em dois anos, a gente faz vários grupos de trabalho, mas com alunos do primeiro semestre, do segundo, terceiro... Até lá em cima, que é pra ter essa comunicação vertical, que isso é interessante. Quando nós montamos, lá em Brasília acharam ótimo, uma faculdade usou isso e foi louvável, elogiado. Então eu passava filme, tem muito sobre meio ambiente, sobre tecnologia, sobre tecnologia dos edifícios, desde coisas modernas como antigas. Você tem a embaixada da Alemanha, tem... Eu passava, a cada seis meses, cada turma nova eu passava. Eu queria trazer a turma, sair de Manaus, que ainda não era nada, aí fizemos um livro de ouro, que deu sorte, e que deu dinheiro pra gente vir de avião, se hospedar num hotel ali no Flamengo. A "Camarca" não deu dinheiro, mas deu um dia inteiro na ponte, os alunos todos participando, vendo o tipo de fundação, a parte de profundidade, câmaras de descompressão, para os que trabalhavam lá embaixo. Também trabalhavam no escuro, com aqueles anéis todos que vão interligando. Era com vapor quente, tudo coberto de plástico... Então essas coisas foram muito importantes, hoje um é presidente da federação, outro vai ser o maior funcionário da IBM, todos eles foram embora. E eu levava todos os alunos para as obras, marcava com a construtora, empregava, e vinha embora com os alunos explicando tudo, quando era o caso de eu levar... Mas eu chegava num profissional de um edifício que nós tínhamos projetado, o engenheiro era um português competentíssimo, tudo programado, uma beleza, e eu passei pra ele, depois, mostrando o esquema de cada prédio e os pilares que iam fundir. Estava previsto no bloco x, ser daqui a dois meses. Isso em azul, e em vermelho a data, quer dizer, escrevia, e a data em que foi feita. Tudo batendo, certinho, tudo certinho.

Quer dizer, isso pra eles abre a cabeça, abre muito, a nós todos. Aí eu passava o filme japonês a cada seis meses. Depois eu passei a fazer na minha casa, aí os alunos vinham de noite e vinham os nossos amigos também. Aí virava uma descontração. E são coisas assim. Tem aluno que nunca entrou em obra, nunca viu nada. E por que não? Basta acompanhar uma obra, para a firma seria maravilhoso. Ou então pedisse que tivesse vídeo, para passar. Para a firma é uma promoção. E isso eu acho importante. 
Leticia: Quando o sr. começou a dar aula?

Severiano: Em 92. (...) Então o que eu vejo é essa ausência de levar... Por exemplo, as faculdades têm em todo lugar, São Paulo tem japonês com tudo isso lá. A nossa arquitetura japonesa aqui no Brasil quase chegou na Amazônia, foi no salão nobre da universidade, com o reitor, com todo mundo. Aí eles pediram pra eu fazer a apresentação, eu tinha um livro grande que eles tinham me dado. Então eu fiz uns slides e expliquei tudo, aí quando eu acabei de falar entrou os filmes da arquitetura tradicional, tinha maquetes. Ficava fazendo análise da poluição, que desaguava nas baías. Então essas coisas todas eram importantes pra eles. As provas também eram todas feitas em sala, o trabalho não levava pra casa, era em sala. E aí eu podia ajudá-los. Porque aí ia pra casa, tem trabalho, tem família, não sei o que, não vai dar tempo, cheio de coisa pra fazer. Aí a gente discutia, e eu ajudava. Precisava ser inteligente pra comprar terreno direito, um terreno que fosse bem ambientado, enfim, uma série de outros fatores que a gente via. E eu vejo que nós tentamos fazer, para os alunos, na parte de obra eu acho que é uma deficiência, porque você aprende com o operário.

Quando eu cheguei em Manaus, que eu comecei a fazer minha primeira casinha, eu fiz bem simples. Porque eu tinha feito umas escolas pré-fabricadas, que o governo não construiu nenhuma. Eu doei, logo no início, em 65, para o governo. Foi publicado na revista do IAB de pré-fabricação, e eles não construíram. Passou um mês, dois meses, seis meses, e eu perguntei - Poxa, seu secretário, por quê? Ele disse - É que o secretário do planejamento disse que vão dizer que a revolução está construindo barracos. Então eu fiz a minha casa assim. Então eu estava com um monte de piso, tábua de assoalho normal, macho e fêmea, depois também na vertical. E aí eu fui morar nela, tinha até um riacho que passava que a gente tomava banho, tinha uma piscina natural. (...)

Depois eu fui fazer o restaurante chapéu de palha. Eu conheci os postes das árvores, porque 0 secretário de obras era engenheiro eletricista da companhia de eletricidade, e os postes lá duravam muitos anos, tem aquariquara, que dura 80 anos. Aí eu fiz o chapéu de palha. E como ele, antes de inaugurar, recebeu prêmio aqui, do Instituto de Arquitetos... Mas eu estou dizendo, aí mudou. Tinha fila na inauguração, e nós construímos em poucos meses, tudo com palha. Mas a palha, era como se fosse uma folha de bananeira, mas não molinha, rasgando. (Severiano começa a desenhar) Ela chegava, virava, e fazia assim. Aí passava essa que prendia na ripa, aí vinha essa e depois botava a outra aqui aí e prendia com o martelo. Não era ripa porque era um pau roliço, tudo era em pau roliço. Aí eles diziam - Doutor, como é que faz isso - e eu dizia - Não sei. Aí eles resolviam - Não, deixa que eu...

Pra pegar um pau de $14 \mathrm{~m}$ de comprimento, uma árvore, pra suspender, pra botar num buraco, eles pegavam no centro de gravidade, botavam uma palha aqui, botavam um tripé e suspendiam. Quando 
chegava num determinado ponto, eles diziam - Senta aí - e fulano sentava e continuava subindo. Depois quando ficaram todos aqui, eu estava com medo daquilo girar, tanto que eu tinha mandado fazer uns anéis que travavam. Aí eu disse - Eu vou lá em cima - Vai lá, doutor. Aí eu subi lá - Pode tirar isso daqui, que isso pode girar - Não, doutor, é leve, pode pegar. Aí eu peguei assim, foi e voltou, porque estava quase na vertical, então não tinha peso nenhum.

Aí as palhas - Doutor, como é que a gente vai botar as palhas? A palha no sentido dos ventos, vai assanhar elas. Aí eu disse - Não sei. (Ele começa a desenhar) O vento viria daqui. (...) Aí eles enfiaram um preguinho aqui, nessa, na outra, na outra, por cima da palha, e passava um arame. Ninguém via. Aí a gente vai aprendendo. O tempo todo você vai aprendendo. Quando eu fui fazer o apartamento, eu tinha já 13 anos de obra, 11 anos de formado. Eu tinha uma experiência grande, porque os mestres aqui foram meus grandes professores, eram muito prestativos, me trataram muito bem.

Leticia: O sr. acha que a faculdade te deu um embasamento bom para começar a trabalhar lá?

Severiano: Grandíssimo, porque a gente tinha aquele boom. Todo um prédio, a gente vendo arquitetura, não tinha presença obrigatória. Quando tinha uma conferência, fechava, todo mundo ia lá. Então foi muita rica a faculdade naquele momento. Os professores eram todos muito bons, eram calculistas mesmo, faziam os projetos deles lá. Então foi uma fase muito boa pra gente.

Leticia: Mesmo no começo, quando o sr. chegou em Manaus...

Severiano: Mas eu estava no Rio. Eu fui pra Manaus... Eu me formei em 1954.

Leticia: Trabalhou mais de dez anos por aqui.

Severiano: É. Fui em 65, foram 11 anos. 0 escritório ficou sempre aqui, porque lá não tinha infraestrutura, não tinha ninguém para pegar catálogos, você não tinha contato, não tinha calculista, era tudo aqui. Também a parte mais importante é a parte de controle de obra, em que o Wilber Guedes, que era um engenheiro, que era do Banco do Brasil... O Banco do Brasil, como construía no Brasil inteiro, desenvolveu uns contratos, uma série de coisas que permitia você... Primeiro tinha o orçamento do local da obra, quantitativo geral da obra, eles faziam tudo isso. Depois a gente marcava o prazo de andamento de cada etapa, e se a firma não cumprisse aquele prazo parcial, pagava uma multa parcial. Se ele recuperasse, era devolvido, senão ia acumulando. Então eles entregavam três vias só de concorrente, com minuta do contrato, normas de execução. Se ele começasse a fazer e caísse de nível, ele parava. Então isso resolve pra que não perca muito tempo, o governo extremamente seguro. E eu com o relatório mensal, com fotografias; eu fui mais fotógrafo na vida do que arquiteto. Você fotografa o tempo todo, interessante. Foi uma fase muito boa. 
Todo projeto que eu fazia eu mandava pra premiação. Eu vi que pra uso interno eles tinham aquela mania de dizer que iam construir barracos, aquilo tudo... Então começaram a prestar atenção nas construções. A SUFRAMA é toda de concreto. Por quê? Porque tinha a zona franca, a SUFRAMA é a superintendência da zona franca, e aí eles disseram - Puxa, Severiano, você vai fazer a sede, vai ser bom, tudo de madeira. Aí a gente fez aquelas cúpulas assim (Severiano desenha), de 15 por 15, e em cima aberto, e esticava assim e aqui tinha a calha. $E$ aqui vinha, este lado aqui por baixo, e isso era a estrutura. Porque a SUFRAMA eu não sabia como é que ia ser o layout deles, o negócio estava começando. Então eu fiz uns grandes vazios, com 7500 metros, e permitindo que eles fossem acompanhando as necessidades. Mas eles queriam mesmo é chamar a atenção do cliente. Finalmente pegou fogo tudo isso aqui porque houve uma necessidade de sumir com alguns papéis irregulares. Aí eles me chamaram e aí a gente fez tudo em concreto, e hoje ela é lindíssima. Eu gosto muito dela. Você vê concreto, você vê estrutura metálica, você vê...

A universidade é toda metálica. E no entanto, inicialmente, a gente tinha feito, em 73 , casas com prémoldados de concreto, aí nós fizemos isso aqui, está vendo as divisórias ali no corredor? (mostra uma foto) Aquele branquinho ali embaixo é um kit, quer dizer, tem aqueles painéis deste tamanho, tem aquela caixinha, tem aquela janelinha de basculante, esta com três basculantes ou então com duas paradas. Então você botava este perfil e entrava o painel branco debaixo, do mesmo jeito que entrava a esquadria. Alguns anos atrás eu estava em Manaus, o reitor disse - Isso aqui é uma maravilha. Ele quis mudar o gabinete dele porque eles não tinham dinheiro para construir, então fizeram o prédio da reitoria. Então eles fizeram um desse e ocuparam tudo com a reitoria, porque no dia em que fosse fazer uma reitoria isso se integrava nos outros cursos. (Mostra o desenho de um corte do edifício) Aqui na cúpula, subindo assim, tem uma folha de madeira passando embaixo dessa viga. Então isso ficava embaixo do concreto e aqui a gente assoalhava por baixo tudo aquilo, e você podia depois mudar aqui internamente. Já aqui a gente fez na direção uma janela na horizontal, por dentro, e aqui em cima era aberto, que é pro ar quente sair. E do lado oposto era bem alto, senão todo mundo que passasse aqui avistaria o pessoal. Do lado oposto era assim, era tudo na horizontal, senão o vento era jogado pra cima. Eu só não abaixei mais porque podia ter cobra.

Leticia: Mas hoje em dia ainda está assim?

Severiano: Ainda está. Pode ter desmatado algumas coisas, mas muito pouco porque tem 14 nascentes e eles preservam essa parte.

Leticia: $O$ conforto sempre foi uma prioridade em seu trabalho. 
Severiano: É. Você quer ver um negócio? Eu estava escrevendo sobre o que é arquitetura. Ontem que eu fiz isso.

Arquitetura é um conjunto de fatores que se entrelaçam e se agrupam de acordo com as necessidades de um programa, as condições específicas de uma área, os recursos da sua região, suas condições ecológicas, tecnologia a ser empregada, antiga, regional e todas as demais existentes em sua época, recursos financeiros, etc. Tudo isso ordenado, transformado em espaço de maneira sensível, lógica, técnica e bela.

Isso que eu vejo, uma coisa que vai ser feita. Na nossa época, eu passei um fim de semana com os amigos de infância, e a gente saía sempre junto, viajando junto, eu estava conversando com eles Vocês se lembram, toda obra antigamente, o tapume na frente tinha três lugares, um pra jogar areia, aí que vinha aquela madeira, do lado de dentro o caminhão encostava e jogava brita, tinha um quarto fechado pra cimento, tinha o alojamento dos operários, embaixo tinha um escritório pra gente, e tudo era assim. Hoje você tem aquele caminhão betoneira que joga lá em cima, e que faz tudo. Você compra o ferro e já vem dobrado, cortado, exatinho como o calculista especificou. Então é uma série de coisas assim, que... Mão-de-obra também melhorou o nível do trabalho, mas teve um vazio muito grande do pessoal mais ignorante. Ignorante no bom sentido, de recursos. Então é isso, e eu digo que todo dia essa evolução é concreta, com equipamentos, com tudo isso. E por isso, mais uma vez, é necessário que todos os alunos e professores de material de construção, de tudo isso, faça contar. Eu, por exemplo, fazia o seguinte: eu pegava, tirava xérox da minha chamada, dos meus alunos, aí mandava para várias firmas, de serragens... Tinha uma porção delas que eu tinha facilidade, aí eu mandava - Estou encaminhando uma lista para vocês mandarem seus catálogos para meus alunos, que serão seus futuros clientes. E mandava toda a relação. Aí eles levavam um susto (...) Então isso acontecia.

Isso hoje, catálogos, está tudo obsoleto. Como também a pesquisa. Fui visitar prédios, fui visitar escolas, fui fazer hospitais e visitei uma porção de hospitais, o CEASA visitei de Fortaleza, de Pernambuco, do Rio de Janeiro, Rio Grande do Sul. Primeira vez, quando eu não sabia se ia ser central de abastecimento ou mercado produtor. Eu via com os olhos do que era pra ser pra Manaus. Quando, quatro anos depois, me chamaram pra fazer o CEASA mesmo, eu fiz outra vez tudo. Aí as dicas de funcionamento, pelo zelador, pelo pessoal, é que te orientam pra você não cair no mesmo erro, porque senão você, pela lógica, vai entrar com tudo e depois na realidade não funciona.

Então os alunos, que estagiaram pra mim, estão todos fazendo obra, eu mandei todos pra obra. Tem uma de Ribeirão Preto, e deve vir pra cá, já deve estar terminando. E estão trabalhando também, os outros todos, em construtora, pra poder partir para a parte de fazer. E mais é pra você sentir. Por quê? 
Vou fazer um hospital, fizemos um hospital em 58. Aí eu fui visitar um hospital em Brasília, um médico do Amazonas, e visitei tudo, de Taguatinga, de escritório em Brasília, das forças armadas, e tal. E ele explicando, ele também era chefe de hospital. Aí quando eu comecei a fazer o estudo, chegou uma porção de fontes, eu estava já chegando a um ante-projeto. Tinha uma porção de coisas pra ver. Aí voltei outra vez com ele, e ele me dava uma série de dicas - Severiano, quando você for fazer a parte de ambulatório, depois serviços auxiliares de diagnóstico e tratamento, quer dizer, raios x, tal. Quando você for fazer laboratórios de análise também, então você deve fazer de tal forma que tudo isso possa crescer. Então o projeto da Santa Casa (Severiano desenha), depois daqui dessa circulação tinha este outro bloco aqui. Tinha este outro bloco aqui que ficava a parte de análise, etc., só que aqui pontilhado prevendo... Porque com a evolução tecnológica, chega um equipamento novo, porque todo dia está evoluindo, eles estavam falando, e que não torna obsoleto o anterior, mas vão surgindo outros. Então chega aqui, aí eles dizem assim - Não temos lugar para expandir. Lá junto da cozinha tem um espaço grande, então instala lá. Quer dizer, aí virou bagunça. E as enfermeiras da escola de enfermagem sabiam informar tudo pra nós, porque o médico não repara, vamos dizer, não vive essa parte. Então é importante, essas visitas sucessivas.

Eu vejo muito assim... Eu não vejo mistério, e vejo uma coisa que a gente domina, tem que pesquisar bastante. Agora, tem uma coisa triste hoje, é que a lei, como virou isso tudo... Eu fiz o projeto da casa de um filho, com uma folha A3, cortada no meio. Aqui eu fiz a plantinha dele em 1:200 (...), isso nessa partezinha aqui (Severiano mostra em uma folha). Aqui embaixo você fazia o corte, também esquemático. Então fazia isso, botava aqui a medida. $E$ do lado de cá você botava a área, botava 0 local, o proprietário. E você entrega hoje essa folha e amanhã vai buscar, aqui em Niterói. Não tem detalhe, não tem nada. Então qualquer um faz, e não há controle, o que facilita muito as pessoas a fugirem do projeto, não ajuda o profissional que faz.

Mesmo uma construtora, que tinha um arquiteto, ele não sabia nada; e ele tinha obra. As vigas, na casa dos filhos, ficaram todas assim, cediam no meio, e os operários dele não sabiam escorar. Então depois eu tive que encher de argamassa aqui, pra poder nivelar. Ele não tinha a menor noção de obra. Tinha uma parede aqui desse jeito (Severiano desenha), e ele fez essa massa assim e a outra ficou assim, e aqui tinha uma porta, aí teve uma peça de madeira, que era desse tamanho, e outra para a porta. Então era assim, ele não sabia nem controlar. Ele é vítima e depois a população também. Você imagina na medicina, é a mesma coisa. Só que aqui fica feio, a gente se chateia, quando tem calculista também que não tem tanta experiência assim, mas se ele tirou o diploma, a culpa é do sistema, infelizmente é por aí. 
Leticia: De suas obras em Manaus, em questão de conforto, quais você considera, em relação à ventilação...

Severiano: Você vê a universidade, teve premiação não só no Rio de Janeiro, como na Bienal de Buenos Aires também. Esse aqui é um exemplo (mostra um painel da residência Schuster). Isto aqui está em Manaus, o rio está logo ali embaixo, um braço do rio, é de um topógrafo austríaco (...) Então eu fiz essa casa, fiz uma área central vazia, aqui era vazio até em cima, do lado tinha a cozinha, do lado de cá ficavam os quartos, e isso aqui em cima. Só que era tudo aberto. Eu conhecia o Schuster, e foi até uma das coisas bacanas que eu fiz, ali é a escada, ali em cima ficava a caixa d'água, caixa de fibrocimento, e os quartos eram do lado de cá, e ali dentro então tinha um vazio grande, continuação, não tinha parede, nada. Está vendo aquelas janelinhas ali? Ali era a sala de almoço, e naquela parte fechada de alvenaria, em cima da madeira, ali é a cozinha, e embaixo tinha a sala de estar.

Essa casa era tudo aberto, o vento passava pra lá e pra cá, tranqüilo. E o Schuster não quis nem que pusesse fechamento em cima, e eu disse - Schuster, mas tem morcego, caranguejeira - Ah, Severiano, elas sobem, não tem problema.

\section{$(\ldots)$}

Então, você vê, lá o homem domina madeira, faz tudo, e lá eles dominam a técnica. Balbina foi quando a Eletronorte entrou, e estava fazendo uma hidrelétrica. O Centro de Proteção Ambiental da Hidrelétrica de Balbina, tem vários laboratórios, parte experimental, impacto ambiental, porque é a primeira e única, ainda, hidrelétrica na Amazônia. Com aquele desnível tão pequeno, ia fazer Balbina. Então eu fui fazer esse programa.

Quando eu estava fazendo o Instituto de Pesquisa da Amazônia, eu tinha dito - Eu não quero que dêem nem o programa. Aí não deram, só fizeram um relatório de defesa animal, um relatório de defesa vegetal, aí eu me mandei de Manaus pro Rio, fui pra antes de Barra Mansa, tem no quilômetro 14 a escola de Agronomia. Aí eu fui lá, conversei com os professores e alunos de defesa vegetal, eu fui lá com eles - Professor, é o seguinte, eu sou arquiteto e fui chamado pra fazer um laboratório de defesa vegetal, então eu queria uma orientação. Ah, que interessante - chamou gente - leva ele, vai mostrando o herbário. Então depois ele foi comigo, me orientou. Aí eu fui dali pra defesa animal, aí a defesa animal disse - Aqui está muito ruim, então é melhor você ir lá na praça XV, que lá é também a defesa animal do Brasil. Aí eu fui lá, fizemos juntos um programa inteiro, como é que devia ser, onde você guarda as cobaias. Se ela entrar na sala da pesquisa, ela, usada ou não, vai ser incinerada, porque pode estar contaminado o espaço. As pessoas que assistem, estão aqui sentadas, vão 
ouvindo, assistindo, outros técnicos. E tudo que faz ali, tudo tem uma 'queimatória', logo que acaba coloca fogo em tudo. Quer dizer, quando é que iriam me informar isso em Manaus, nunca.

Anos depois uma firma alemã queria fazer umas vacinas, fazer um acordo com a secretaria de produção, que era de agricultura. Aí disseram - Me vê um projeto aí, com laboratórios... Quando eles olharam, estava perfeito, tinha tudo, essas coisas todas. Porque uma das coisas nossa foi sempre fazer essa pesquisa. Eu levava os professores. Eu levava, por exemplo, quando eu fui fazer a faculdade de Engenharia, nós fomos com os professores de civil, de São Paulo, USP, fomos pra São Carlos e fotografava, fazia um prospecto o dia inteiro, do que é que tinha que ter, no laboratório $x$, etc. Nós saímos dali, esses já iam embora, nós tínhamos oito professores fazendo pós-graduação, que participavam. Tinha essa troca de informações. Aí saía essa turma, entrava o pessoal de comunicações, aí nós saíamos para o IPT, pra USP, pra São José dos Campos, depois Itajubá lá em cima.

\section{$(\ldots)$}

Nós estávamos em Itajubá, aí o chefe da prefeitura veio. Aí nós entramos - Nós somos do Amazonas e estamos pra fazer agora a parte de laboratório e viemos aqui pra vocês nos ajudarem. Ele falou - Não, aqui está cheio de problema, como esse, assim, assim... Aí eu disse - Se você quiser, a gente pode dar uma ajuda. Ele - Pois não. É que lá embaixo, em São José dos Campos, tem um laboratório em que as arquibancadas são muito bem feitas, porque conforme a pesquisa que estão fazendo eles vão levando pra botar lá em cima, pra mexer com gravidade, e tal. Aí ele falou assim - Por que vocês vieram lá do Amazonas, pra me dizer que lá tem tudo, como se aqui lá fosse meia hora, quarenta minutos. Mas é importante porque você fica mais atualizado, senão depois fica defasado. Mas fundamento é na pesquisa, e aí o material, a técnica construtiva, tudo isso, vai entrando, vai se encaixando.

Em 73 nós fizemos um pré-fabricado, a universidade. Nós não conseguimos financiamento no BID, tanto que eu levei cinco arquitetos pra Brasília pra participar dessa reunião do BID, que ia financiar um monte de universidades brasileiras. E nós não fomos, primeiro porque só a turma que ganhou, já tinham as suas próprias universidades, o dinheiro foi só pra elas mesmo.

Leticia: Por que vocês escolheram pré-fabricado, na época, para a universidade?

Severiano: Porque ficava autoportante, você fazia as vigas, dava uma certa flexibilidade. Ao longo dos anos de 73 até 79 , ia sempre o pessoal do ministério da educação lá, e falava - Se eu der pra vocês $x$ mil, vocês não têm como gastar em um ano, porque essa verba tem que terminar no fim do ano, e 
vocês não têm condições. Porque lá tem o período da chuva e tem o período da seca pra trabalhar. Aí aquilo ficou dentro de mim.

Aí, sabe de uma coisa, eu fui lá em Volta Redonda. Aí eu pensei - A gente faz a laje toda, sem cortar o terreno. Toda vez que tivesse um desnível no terreno de $50 \mathrm{~cm}$, então a gente fazia isso. Agora aí eu imaginei... Fazia isso, aqui ficavam os parafusos pra entrar a base do pilar (Severiano mostra uma foto). E aqui tinha esse assim... Do lado de cá estava a segunda coluna. E este é do telhado mais alto, este é do telhado mais baixo. Então nós fazíamos isso aqui e depois era só armar, isso já chegava, estava esperando, parafusava aqui, armava, cobria, aí trabalhava. Ficou bem firme, até hoje.

(..)

Com isso a gente fez um negócio flexível demais, acompanhando sempre o desnível. Tem uma rampa de $50 \mathrm{~cm}$, a rampa pro deficiente físico é mais suave, vai mais na frente. Aonde pára tem um degrau, aonde 0 aluno salta tem cadeiras pra deficientes. 0 próprio obstáculo impede que deficiente vá estudar em uma faculdade, numa PUC, talvez na USP. Mas nós fizemos assim.

Então a vantagem foi essa, porque virou um padrão forte, muito bom pro clima. Agora, a cidade mudou o clima, cresceu, expandiu, ficou calor. Porque desmataram, o vento quente e úmido, que a gente não desidratava tanto, virou quente e seco, porque desmataram tudo, fica só esse oásis da universidade, o resto tudo, tudo, o distrito inteiro. Hoje Manaus é muito calor, então já pede ar condicionado, e fecha tudo e eles põem. Nos laboratórios tinha. Nos laboratórios, em cima, vai passando aqueles dutos forrados de alumínio, grandes, e que vai passando e fica nas extremidades. Então tem ar condicionado.

Leticia: O sr. acompanha as reformas, as ampliações?

Severiano: Não.

\section{$(\ldots)$}

Uma vez eu ia andando, eu estava saindo no corredor, nessas passagens, aí veio uma aluna e me disse - Mestre, eu queria falar com o senhor. - Pode falar. - É que o professor me deu um trabalho, de solos moles, e eu queria falar com o senhor. Eu disse - Olha, é o seguinte, eu sou arquiteto - Eu sei. Fale com o seu professor de estruturas, de fundações, que isso é mais com eles. - Não, mas eu quero é com o senhor mesmo. Porque, é lógico, eu não calculava. Mas isso acontecia lá. E era uma fase boa.

Leticia: O sr. vendeu sua casa lá?

Severiano: Vendi, já foi demolida, e o proprietário que comprou, era um advogado, pediu que eu fizesse uma justificativa de vender, e pôr abaixo qualquer obstáculo. Eu cheguei em Manaus, em 65, tinha orvalho na minha rua até lá em cima. Era neblina até em cima. Lá em casa, eu morava $200 \mathrm{~m}$ 
abaixo de um rio. Chegava macaco, preguiça, chegava jacaré dentro do quintal da gente. Aquilo tudo de manhã era neblina, tinha até um orvalho, toda noite era orvalho. Depois disso tudo, minha casa que eu fiz é toda furada, toda de elemento vazado, aqui em cima tinha madeira que chove, tem um jardim interno do lado de lá, na sala (mostra um desenho). Aqui era sala de televisão, aqui era mesa de jantar, aqui era a sala de estar, umas varandas aqui fora, e aqui era um jardim interno, aqui em cima aberto, chovia aqui dentro, elemento vazado. Eu fiz o escritório aqui nessa sala e botei um "sprinter" alto, imenso, de potência, porque o calor era muito grande. E como todas as minhas janelas eram de madeira, aqui $15 \mathrm{~cm}$ de afastamento, e tinha aqueles vidrinhos 'jalousie'. E amarelos, para reduzir a luminosidade, então a casa era fresca, antigamente, não sentia falta de ar condicionado, era só veneziana. Depois ficou um horror de calor. A cidade mudou, tudo mudou, então não tem mais sentido aquela casa toda aberta, precisa fechar tudo. Foi então que aconteceu.

Leticia: Quando ela foi demolida?

Severiano: Faz uns dois anos, ou mais. Mas o IAB juntou e desmoronou a casa, desmontaram as madeiras, tudo numerado, os estudantes foram pra lá. Isso me disseram. E está tudo guardado, numerado, esperando que a prefeitura dê um terreno bem localizado, porque eles têm dado uns terrenos ruins. Eles aí vão montar lá para ser a sede do IAB. Aí não tem por que, não tem aquele fim, botei ar condicionado, mudou tudo. Tem que ter ar condicionado. Então é mais ou menos isso.

Leticia: A casa do Schuster ainda existe?

Severiano: Ah sim, uma pessoa comprou (...)

Leticia: E como ela está?

Severiano: Mantiveram, ela está bem tratada. Porque ela não é no centro, é na beira do rio e bem longe.

Leticia: E o banco da Amazônia?

Severiano: O banco da Amazônia não tinha problema porque era ar condicionado. A luminosidade é muito forte aqui. Se você chegar aqui você vai sentir o calor das paredes. Quando o sol está mais forte, a radiação, a luz também. Parece que acabaram com o banco da Amazônia, um banco particular comprou. Mas eu acredito que por ser um banco eles vão manter a agência, porque tem caixa forte, tem tudo ali. Agora eles ficavam muito felizes, todo aniversário eles chamavam pra ir lá. Aniversário do banco. Os funcionários todos faziam uma festa. 
A ilusão de que arquiteto é que projeta as cidades, isso é uma ilusão. O arquiteto hoje, nas prefeituras, faz 0 que o prefeito quer. E tudo é esquema. As firmas todas, fazem um negócio, ganha esse, ganha aquele, então é uma dificuldade muito grande. A gente teria que ter realmente... Sei lá, não sei como é que poderia.

Eu levava os alunos para os órgãos todos, pra visitar, as secretarias. As secretarias tinham toda a parte de planejamento, de tudo isso. Quando foi criada a zona franca, depois da zona franca teve o mesmo plano diretor de Manaus, feito por uma firma de São Paulo, por sinal muito bom. Aí eu pedi licença na faculdade e passei os três dias assistindo às reuniões, de manhã até de noite, com a firma explicando no auditório os planos todos, porque eu obriguei os alunos a ver. Amanhã um deles poderia ser secretário de obras, aí já tinha outra visão.

Perto de casa tinha um igarapé grande. (Severiano desenha) Do lado de cá tinha a rua, e aqui a água escorria. Quando dava uns temporais fortes, chegou um dia a passar por cima dessa rua aqui, aqui embaixo tinha um canal. Então a água ia chegar aqui, mas agora você veja, aqui é um triângulo, subiu um metro, outro metro, olha a quantidade pequena de água que tem aqui, um metro já é isso tudo, outro metro é muito mais. Aí sabe o que fazem hoje? Já fizeram em São Paulo, estão fazendo em tudo que é lugar. Eles fazem um canal, porque amplia aqui as pistas, e então sobe a mesma quantidade, mas o volume é muito maior. Se naquele tempo já passou a água por cima da rua...

Aqui antes tinha o parque 10. E o parque 10, eu já tinha feito uns projetos pra lá, a água passou 20 horas correndo por cima da rua, e entrando, tinha um zoológico, levou tudo. Foi em 69 que aconteceu isso. Anos depois, eu estava fazendo um projeto aqui, eu marquei o nível da água, como o caboclo faz, as árvores ficam assim, aonde a água sobe fica a marca, a gente toma como referência. Aí a parte que ia atender ambulatórios médicos, eu fiz um muro de pedra aqui, mandei aterrar e ficou mais alto. Anos depois, porque isso acontece quase que de 20 em 20 anos, 17 anos. Pra nós é dia sim dia não, porque nós só vivemos 100 anos. Depois aconteceu isso, foi engraçado porque tinha o estacionamento aqui e os carros foram recuando, recuando. E só ficou de fora essas casas que nós fizemos aqui, porque vemos a do caboclo. Isso que eu digo, que a gente perde essa sensibilidade, de sentir, de ver.

\section{$(\ldots)$}

Leticia: Como está Balbina hoje?

Severiano: Olha, eu não sei. Mas ela existe, às vezes dizem que está bem conservada, depende da administração. Aquilo foi só pra evitar briga. Porque ia inundar um mundo danado numa região que não tem altura. 0 máximo que podia ter de água eram uns $20 \mathrm{~m}$ aqui, então não tinha água nenhuma, ela 
produz um percentual bem pequeno das necessidades de Manaus, insignificante quase. E o resto é termelétrica.

\section{$(\ldots)$}

(Severiano mostra o projeto da Central Telefônica em um livro)

Hoje, com o avanço tecnológico, tudo isso cabe em um container desse aqui, todas as instalações. Foi feito depois um segundo pavimento, eu já deixei previsão de subir, agora tudo isso aqui, bastava um container. Aqui fizemos essa parede, tem tijolo aqui, tem um atravessado, aí fica $5 \mathrm{~cm}$ vazio. Aqui embaixo tem uns buracos pra entrada de ar, e a saída é lá em cima. Então quando começava a esquentar aqui o vento entrava em cima, irradiava pra dentro, que era com ar condicionado. Essa viga aqui, em $U$, foi calculada pra fazer uma viga aqui dentro também e fazer o segundo pavimento. Aqui tem elementos vazados, sol da tarde.

Foi criada a Companhia Amazonense de Telecomunicações em 65, depois nós fizemos as do interior, as duas primeiras, Parintins e Itacoatiara. Aqui já foi a polícia militar (mostra no livro), aqui são os alojamentos, interessante. Eu fiz aqui uns armários, aberto embaixo e aberto em cima, e era pra rede, porque todos os quartéis do exército usavam rede. Então cada soldado tinha um armário, aqui embaixo tinha um banco pra duas pessoas, porque eles precisavam se sentar. Então de dia eles enrolavam a rede e punham embaixo, no armário ali. Tinha um pilar aqui e outro pilar no meio pra botar as redes. Se tivesse necessidade de muita gente, o cara do plantão ficava de um lado, e embaixo aqui do armário tinha um banquinho de madeira, porque aí você fazia uma sala de estudos, não tem ninguém durante 0 dia aqui mesmo. Aqui eu fazia cada frente oblíqua, pra não bater sol.

Aqui já foi a Secretaria da Agricultura, foi um dos primeiros projetos também. Esse aqui é interessante, eu fiz só esses armários, e em cima madeira, os pilares são armários embutidos, e um beiral bem grande. Inclusive eu gosto muito do telhado dele. Aqui o auditório, foi na descida. Você vê os detalhes. Esse número de detalhes que fez a gente ter o sucesso que teve, porque tudo dava certo. (...)

Aqui era o Parque 10, aquele que eu estava te falando que a água subiu. Esse bloco aqui é que eu salvei, esse aqui era um restaurante, ficava sempre debaixo d'água. Foi esse que a água passou por cima, levou o zoológico que tinha aqui todo. Esse bloco aqui é o que a gente fez mais alto. Aí eu fiz essa viga com uma coifa pra esse triângulo de madeira, e aqui a calha, a água vem, cai aqui. Sempre aberto, bem ventilado. Eu estava com a força total. Em 65, eu me formei em 54, 11 anos de formado, e obra, obra, obra.

Leticia: E foi construído no parque? 
Severiano: Não, só foi feito aquele bloco da administração.

Esse aqui foi o hotel de Silves. Tinha um alemão que era muito amigo, ficava no banho com a gente. Banho é uma piscina que passa, é um riacho que vem de água limpa, e passava por dentro. Então eles fazem o seguinte, tem uma porção de madeira aqui, de pedra, aqui tem uma comporta de madeira, então ele fecha a comporta aí o riacho passa aqui, enche. E quando vai lavar abre tudo. Ele disse Severiano, aqui tem que ser hotéis regionais, teria também que ser feito um trecho, porque a pessoa sai daqui, pernoita nesse, depois pernoita nesse aqui, depois vai nesse. Aí então eu fiz isso. (...) Aqui tem o segundo pavimento, aqui cai e entra aqui no meio. Aqui os quartos em cima. E aqui é palha. (...)

Esse aqui é o Chapéu de Palha. Primeiro eu fiz os tirantes, então essa aba aqui fora, era só o tirante que vinha na madeira, pegava ali. E a cozinha pega esse trecho aqui atrás, banheiro, etc. Tinha que fazer esses dois anéis e travar eles antes de soltar, porque eu tinha um medo desse troço girar assim.

$(\ldots)$

Aqui foi a escola de pré-fabricados. Aqui podia ser três salas de aula. Porque não podia ter aula no interior porque não tinha residência... O secretário de obras, em 65 - Não pode faltar escola mas não tem aonde alojar professor. Aí eu fiz o projeto, as salas, os quartos. Eu doei ao governo, tudo detalhado, as sapatas todas já iam prontas. Aqui tinha uma peça de madeira. E aí você passava essa, essa... vinha aqui e botava as venezianas, era tudo armado. Não construíram porque disseram que iam estar fazendo barracos.

\subsection{ARQUIVO DE IMAGENS COLETADAS NO ACERVO DE SEVERIANO PORTO}

\subsubsection{Aldeias Infantis SOS Brasil, 1994}

Projeto executivo:

001- levantamento alti-planimétrico 1:500

002 e 003- planta de situação 1:500

004- planta casa comunitária 1:50

005- casa comunitária - fachadas Sul, Oeste e Leste 
006 e 007- casa comunitária - cortes AA e BB, fachada Norte

008- casa lar - planta, fachada Sul

009- casa lar - fachadas Norte e Oeste

010 e 011 - casa lar - cortes AA, BB, CC, DD, EE, fachada Leste

012- casa das tias - planta

013- casa das tias - fachada Oeste

014- casa das tias - fachada Norte

015- casa das tias - corte CC

016- casa das tias - corte AA

017- casa das tias - corte BB

018- jardim de infância - planta

019- jardim de infância - fachada Norte

020- jardim de infância - corte AA

021- jardim de infância - corte BB

022- circulação/ chapéu de palha - fachadas

023- circulação/ chapéu de palha - corte FF

024- planta geral de vegetação

Detalhes de carpintaria:

025 e 026- esquadrias de madeira

027 e 028- esquadrias de madeira - portas tipo: vistas, cortes, detalhes, seções horizontais e verticais

029 a 032- esquadrias de madeira EM 10 a EM 14 e EM 51 a EM 54

033 a 036- esquadrias de madeira EM 15 a EM 23

037 a 040- esquadrias de madeira EM 24 a EM 31

Originais:

041- anteprojeto - planta de situação 
042- estudo casa lar - fachada principal, planta de cobertura

043- anteprojeto casa das mães - planta

044- anteprojeto jardim de infância - planta

045- anteprojeto alojamento dos visitantes - planta

046- estudo casa das mães - planta

047- estudo casa comunitária - planta

048- estudo centro comunitário - planta

049- estudo refeitório - planta

050- estudo departamento médico - planta, planta de cobertura, fachada principal

051- estudo auditório - planta

052- anteprojeto casa lar - planta

053- anteprojeto casa das mães - planta

054- anteprojeto centro comunitário - planta

055- anteprojeto jardim de infância - planta

056- anteprojeto refeitório - planta

057- anteprojeto criação e arte - planta

058- anteprojeto biblioteca inf. e ativ. de ensino - planta

059- anteprojeto chapéu de palha - vista lateral, corte longitudinal, cobertura, estrutura do telhado

060- anteprojeto auditório - planta

061- estudo auditório - corte longitudinal, corte transversal AA, fachada lateral

062- anteprojeto coleta de lixo - planta, planta cobertura, fachada principal

063- anteprojeto garagem - planta

064- anteprojeto alojamento para visitantes - planta

065- anteprojeto departamento médico - planta

066- estudo casa dos dirigentes - fachada S, planta cobertura

067- anteprojeto escola de mães - planta, fachada Leste, planta cobertura 
068- anteprojeto trabalho com terra - planta, fachada principal, planta cobertura

069- anteprojeto lavanderia/ oficinas - planta

070- estudo centro comunitário - planta cobertura

071- estudo centro comunitário - fachada Leste

072- estudo refeitório/criação e arte - fachada lateral refeitório, corte transversal refeitório, fachada lateral criação e arte

073- estudo biblioteca infantil/ ativ. ensino - fachada principal, planta cobertura

074- estudo auditório/ refeitório/ criação e arte - planta cobertura

075- estudo lavanderia/ oficinas - fachada principal, planta cobertura

076- estudo garagem - fachada principal, planta cobertura

077- estudo jardim de infância - planta cobertura, fachada principal

078- estudo casa das mães - fachada principal, planta cobertura

079- estudo alojamento dos visitantes - planta, fachada principal, planta cobertura

080- anteprojeto auditório/ refeitório/ criação e arte - planta

081- anteprojeto jardim de infância - planta

082- estudo casa lar - planta

083- anteprojeto vestiários educação física - planta, fachada principal, planta cobertura

\subsubsection{Banco da Amazônia, 1974}

Projeto executivo:

001- perspectiva

002- planta de situação 1:100

003 e 004- planta primeiro pavimento

005- planta da sobreloja 1:50

006- cobertura e casa de máquinas 
007- corte transversal BB

008- fachada principal

009- corte transversal AA

010- corte longitudinal CC

011- corte transversal EE

012- corte transversal DD

013- levantamento topográfico 1:500 (10.005 m²)

\subsubsection{Centro de Proteção Ambiental de Balbina - ELETRONORTE, 1985}

Projeto executivo:

001- planta de situação 1:500

002 e 003- planta de níveis

004- recepção, estar, museu, estudos e almoxarifado - planta teto refletido

005- recepção, estar, museu, estudos e almoxarifado - cortes longitudinal e transversal, fachadas Norte, Leste e Oeste

006 e 007- recepção e estar - planta

008 a 011 - museu, estudos e almoxarifado - planta

012 a 015- laboratório de limnologia - planta

016 - laboratório de limnologia - planta da passagem coberta

017- laboratório de limnologia - planta do teto refletido

018 a 020- laboratório de limnologia - cortes longitudinal, transversal, fachada $\mathrm{N}$ e transversal, fachadas Sul, Oeste e Leste

021- laboratório polivalente I - planta do teto refletido

022- laboratório polivalente I - planta

023 e 024- laboratório polivalente I - cortes longitudinal e transversal

025- laboratório polivalente I - fachadas Sul e Norte 
026- laboratório polivalente I - fachadas Leste e Oeste

027- alojamento de redes - planta

028- alojamento de redes - teto refletido

029- alojamento de redes - corte transversal

030- alojamento de redes - corte longitudinal

031- alojamento de redes - fachada Norte

032- alojamento de redes - fachada Oeste

033- área de uso múltiplo - planta

034- área de uso múltiplo - corte longitudinal e fachada Sudeste

035- laboratórios, bloco de sanitários e recepção, estar, museu, estudos e almoxarifado - fachada do conjunto

Originais, ante-projeto:

036 e 037- planta de situação

038 a 040- alojamentos - fachada L, fachada interna e cortes transversais

041- lavanderia, manutenção de jardins e oficina de manutenção dos prédios

042- área de uso múltiplo - planta e fachada Sudeste

043- laboratório de limnologia - corte transversal e fachada Norte

044- laboratório polivalente I e sanitários - corte transversal e fachada Norte

045- laboratório polivalente II - corte transversal e fachada Norte

046- laboratório de endemias-polivalente - fachada Norte e corte transversal

047- perspectiva

\subsubsection{Residência Robert Schuster, 1978}

Projeto executivo:

001 e 002- planta nível 0.00 
003 e 004- planta níveis 2.20 e 3.10

005 e 006- planta nível 5.30

007- planta de madeiramento

008 e 009- corte 1.1

010 e 011 - corte 2.2

012 e 013- corte 3.3

014 e 015- fachada Norte

016 e 017- fachada Sul

018 e 019- fachada Leste

020- planta de localização

021- perspectiva

022- venezianas

023 a 025- explicações do arquiteto

\subsubsection{Superintendência da Zona Franca de Manaus (SUFRAMA), 1973}

Projeto executivo de restauração da sede:

001 a 004- planta pavimento térreo eixos 2/8, B/F

005 a 008- planta pavimento térreo eixos 8/13, C/G

009- planta térreo eixos 10/13, G/l

010- planta subsolo eixo 3/4, B/C

011- planta subsolo eixo 10/11, F/H

012- planta subsolo eixo 12/13, F/G

013 e 014- planta primeiro pavimento eixos 11/13, D/l

015- cortes BB e DD

016- cortes AA e CC 
017- cortes EE e FF

018- detalhe de corte bloco primeiro pavimento

019- detalhe de corte transversal bloco dois pavimentos

020 e 021 - fachadas Sudeste, Nordeste e Noroeste

022 e 023- fachadas Noroeste, Sudoeste e Sudeste

024 e 025- planta auditório, corte GG

026- fachadas Sudeste, Noroeste e Sudoeste

027 e 028- levantamento alti-planimétrico

029 e 030- esquadrias vistas V3, V4 e V5, corte A, corte indicativo e esquema de esquadrias Originais:

031- corte pelas salas de teto vazado

032- corte pelo restaurante

033- fachada lateral restaurante

034- trecho da fachada $\mathrm{N}$

035 e 036- planta de situação

037- fachadas Norte, Sul, Leste e Oeste

038 a 040- cortes

041 e 042- cortes transversal e longitudinal

\subsubsection{Universidade do Amazonas, 1973-80}

Projeto executivo:

001- planta de situação

002- planta restaurante

003- planta de cobertura do restaurante

004 a 007- restaurante - cortes e fachadas 
008- biblioteca - planta térreo, casa de máquinas

009- biblioteca - planta térreo, segundo nível

010- biblioteca - planta segundo nível, terceiro nível

011- biblioteca - planta de cobertura

012- biblioteca - corte CC

013- biblioteca - corte AA

014- biblioteca - corte BB

015- biblioteca - fachada Oeste (lateral)

016- biblioteca - fachada principal

017- biblioteca - fachada Leste

018 a 020- faculdade - planta nível 1

021 a 023- faculdade - planta nível 2, cobertura nível 1

024 e 025- faculdade - planta nível 3

026- faculdade - corte AA

027- faculdade - corte CC e fachada lateral Leste

028- faculdade - corte BB

029- faculdade - corte DD

030 a 032- faculdade - fachadas principal e posterior

033 e 034- planta geral do campus e da rede viária

035 e 036- planta geral do campus

037 a 040- planta geral - pavimento térreo

041 a 044- planta geral - pavimento superior e cobertura

045 a 049- bloco de salas de aula número 2 - planta

050 a 054- área de lazer número 1 - planta

055 a 058- bloco de anfiteatros - planta e cortes

059 a 062- bloco de salas de aula número 2 e número 3 - cortes 
063- corte transversal - bloco de anfiteatros e área de lazer número 2

064 e 065- bloco de salas de aula número 2 - fachadas e elevações internas

066- área de lazer número 1 e cantina - fachadas Norte e Sul

067 a 072- bloco de administração número 1 - planta pavimento térreo

073 a 077- bloco de administração número 1 - planta pavimento superior

078 e 079- bloco de administração número 1, área de lazer número 1 (parte) - planta cobertura

080 e 081 - blocos de administração números 3 e 4 - corte transversal

082 e 083- blocos de administração números 2 e 3 - corte transversal

084-sanitários, blocos de administração números 1 e 4 - corte transversal

085- blocos de administração - fachada Leste

086- blocos de administração - fachada Oeste

087 e 088- bloco de administração número 2 - corte longitudinal

089 e 090- bloco de administração número 1 - fachadas

Detalhes:

091- blocos de salas de aula - corte transversal

092- blocos da administração - corte transversal

093 a 096- esquadrias de madeira M1 a M31 - blocos de administração, lazer, cantina, salas de aula e laboratórios - elevações externas

097 a 099- esquadrias de madeira M1 a M10 - blocos de administração, lazer e cantina - detalhes Originais:

100- perspectiva

101 e 102 - anteprojeto restaurante - planta

103 e 104- vista aérea do campus 
13.2.7 Residência do arquiteto, 1971

Originais:

001- planta de situaçao

002- planta pavimento térreo

003- planta pavimento superior

004- cortes $A B$ e $C D$

005- fachada principal

006- fachada lateral

007- explicações do arquiteto

Projeto executivo:

008- planta de situação

009- planta pavimento térreo

010- planta pavimento superior

011- corte CD

012- corte $A B$

013- levantamento taqueométrico, altimétrico e planimétrico

13.2.8 Residência Alexandre Ale dos Santos, 1982

Projeto executivo:

001 a 003- planta de situação

004 e 005- planta

006 e 007- planta do telhado

008- corte transversal

009 e 010- fachadas Oeste e Norte 
011- churrasqueira, sanitários, vestiário, depósito e bar - planta

012- fachadas

013- perspectiva

014- planta baixa

015- bar, vestiário, sanitários e churrasqueira - fachadas principal e lateral

016 e 017- veneziana regulável, esquadria de correr, treliça de madeira, elementos vazados, portas

\subsubsection{Hotel Silves - Pousada de Caça e Pesca, 1979}

Originais:

001- planta de urbanização

002- planta da piscina e do bar

003- fachada S e corte AA

004- sombreiro - planta e corte

005- planta de cobertura

006- explicações do arquiteto

007- fachada NE

008- fachada SE

009- corte BB

010- corte AA

011- planta do pavimento térreo

012- planta do pavimento superior

Projeto executivo:

013 e 014- planta térreo

015- planta segundo pavimento

016- cortes 1-1 e 2-2 
017- elevações lateral e principal

\subsubsection{Edifício Aracoara, 1987}

Projeto executivo:

001 a 003- planta de situação

004 e 005- planta do primeiro pavimento = planta do pavimento tipo (2 ao 11) sem a laje impermeabilizada

006 e 007- planta do 2 ao 10 pavimento

008 e 009- planta do 12 pavimento

010- corte transversal

011- corte longitudinal

012 e 013- corte transversal e cortes parciais

014- fachada Norte

015- fachada Sul

016- fachada Leste

017- fachada Oeste

018- legenda das fachadas

019- brise das áreas de serviço - plantas, vistas e cortes

020 - corte da jardineira da varanda

\subsubsection{Ipasea ambulatórios, 1979}

Projeto executivo:

001- planta de situação

002 a 005- planta pavimento térreo 
006 a 009- planta do segundo pavimento

010 a 013- planta do terceiro pavimento

014 a 017- planta da cobertura e casa de máquinas

018 e 019- corte longitudinal MM

020- corte transversal AA

021- corte transversal BB

022- corte transversal CC

023- corte transversal DD

024- corte transversal EE

025- corte transversal FF

026- corte transversal $\mathrm{HH}$

027- corte transversal II

028- corte transversal GG

029- corte transversal JJ

030- fachada principal

031- corte longitudinal KK

032- corte longitudinal LL

033 e 034- fachada lateral

035- fachada posterior

036 a 038- elementos vazados de ev. 1 a ev. 5 - elevações, cortes horizontal e vertical e detalhes

039 a 041 - vistas, cortes e plantas - esquadrias M1, M2, M3, M5, M8, M9, M10, M13 a 23

042- detalhes de esquadrias da fachada

\subsubsection{Chapéu de Palha, 1966}

Projeto exetutivo: 
001- projeto de acréscimo - planta de situação

002- planta do restaurante

003- corte (anexo)

004- fachada (anexo)

005- corte AA

006- planta (projeto de acréscimo)

007- planta de situação

008- fachada posterior

009- fachada lateral

Originais:

010- planta de madeiramento do telhado

011- planta do restaurante

012- corte

013- fachada Leste

\subsection{DADOS CLIMATOLÓGICOS DO AERÓDROMO DE EDUARDO GOMES-AM}

Este trabalho foi elaborado pela Subdivisão de Climatologia Aeronáutica (PCA), da Divisão de Pesquisa e Desenvolvimento (DP) do Instituto de Controle do Espaço Aéreo (ICEA). Para elaboração deste trabalho, utilizaram-se informações do Banco de Dados Climatológicos (BDC), as quais foram registradas em formulários meteorológicos preenchidos nas Estações Meteorológicas de Superfície do aeródromo de Eduardo Gomes, localizado no Município de Manaus-AM, no período de fevereiro de 2000 a outubro de 2005, que compõem o acervo do Arquivo Histórico de impressos meteorológicos do Instituto de Controle do Espaço Aéreo (ICEA).

A metodologia adotada consiste no levantamento e processamento das séries climatológicas da estação meteorológica de superfície localizada no aeródromo de Eduardo Gomes, localizado no município de Manaus, estado do Amazonas, e em análises estatísticas das médias mensais, máximas e mínimas absolutas da temperatura do ar, das médias mensais da umidade relativa, pressão ao nível da estação e nebulosidade, dos totais mensais de precipitação acumulada. 
Assim, após o processamento dos dados, apresentam-se tabelas com informações sobre temperatura, umidade relativa do ar, pressão ao nível da estação, nebulosidade e precipitação. 0 horário de funcionamento da estação meteorológica do aeródromo analisado, no período estudado, era de 00:00 às 23:00 horas.

\section{Tabela 1}

Temperaturas médias, mínimas e máximas $\left({ }^{\circ} \mathrm{C}\right)$ absolutas mensais no aeródromo de Eduardo Gomes no período de fevereiro de 2000 a outubro de 2005.

\begin{tabular}{|c|c|c|c|c|c|c|c|c|c|c|c|c|c|c|}
\hline \multicolumn{15}{|c|}{ TEMPERATURA SBEG 2000 A 2005} \\
\hline ANO & & Jan & Fev & Mar & Abr & Maio & Jun & Jul & Ago & Set & Out & Nov & Dez & TOTAL \\
\hline \multirow{3}{*}{2000} & Minima & AUS' & 21,4 & AUS ${ }^{1}$ & 21,7 & AUS $^{1}$ & AUS' & AUS ${ }^{1}$ & 23,0 & 21,7 & 22,6 & AUS $^{1}$ & 22,0 & 21,4 \\
\hline & Média & AUS $^{1}$ & 25,7 & AUS $^{1}$ & 25,4 & AUS' & AUS $^{1}$ & AUS' & 27,7 & 27,5 & 27,3 & AUS' & 26,9 & 26,8 \\
\hline & Máxima & AUS' & 32,8 & AUS' & 35,2 & AUS $^{1}$ & AUS $^{1}$ & AUS $^{1}$ & 36,2 & 36,0 & 35,5 & AUS $^{1}$ & 35,0 & 36,2 \\
\hline \multirow{3}{*}{2001} & Min & AUS $^{1}$ & 22,0 & AUS' & 22,0 & 21,9 & 20,0 & 20,0 & 20,9 & 21,0 & 21,6 & 22,3 & 22,0 & 20,0 \\
\hline & Média & AUS $^{1}$ & 25,7 & AUS $^{1}$ & 26,0 & 26,6 & 25,3 & 26,2 & 28,0 & 27,2 & 28,2 & 28,1 & 26,8 & 26,8 \\
\hline & Máxima & AUS $^{\prime}$ & 32,6 & AUS' & 33,4 & 33,8 & 33,0 & 34,0 & 36,0 & 35,1 & 36,4 & 36,0 & 35,2 & 36,4 \\
\hline \multirow{3}{*}{2002} & Minima & 21,2 & 22,8 & 22,0 & 22,7 & 21,0 & 22,4 & 22,0 & 21,8 & 22,2 & 21,5 & 22,2 & 22,4 & 21,0 \\
\hline & Média & 26,7 & 26,4 & 26,3 & 26,4 & 26,5 & 26,5 & 27,3 & 27,4 & 28,1 & 27,5 & 27,3 & 26,6 & 26,9 \\
\hline & Máxima & 33,8 & 34,0 & 33,8 & 33,6 & 34,1 & 33,5 & 35,2 & 36,2 & 37,8 & 36,7 & 35,2 & 35,9 & 37,8 \\
\hline \multirow{3}{*}{2003} & Minima & 22,8 & 22,3 & 22,6 & 22,3 & 22,5 & 22,6 & 22,2 & 22,0 & 21,4 & 22,0 & 22,0 & 22,0 & 21,4 \\
\hline & Média & 27,7 & 27,0 & 26,6 & 26,5 & 26,5 & 26,6 & 27,1 & 27,3 & 27,0 & 27,3 & 27,1 & 26,8 & 27,0 \\
\hline & Máxima & 35,0 & 34,0 & 35,0 & 34,6 & 34,7 & 33,8 & 34,4 & 35,4 & 36,0 & 35,1 & 35,2 & 34,9 & 36,0 \\
\hline \multirow{3}{*}{2004} & Minima & 22,2 & 21,7 & 23,0 & 22,1 & 21,2 & 21,4 & 22,3 & 21,4 & 22,4 & 23,2 & 23,1 & 21,7 & 21,2 \\
\hline & Média & 26,7 & 26,6 & 26,2 & 26,5 & 26,0 & 26,4 & 26,9 & 27,4 & 27,4 & 27,8 & 28,3 & 27,3 & 27,0 \\
\hline & Máxima & 35,3 & 34,6 & 33,5 & 33,8 & 33,5 & 33,3 & 33,9 & 35,4 & 35,5 & 37,1 & 36,1 & 35,3 & 37,1 \\
\hline \multirow{3}{*}{2005} & Minima & 21,7 & 22,9 & 23,3 & 22,9 & 22,4 & 22,8 & 21,6 & 22,7 & 22,0 & 22,8 & AUS $^{1}$ & AUS' & 21,6 \\
\hline & Média & 27,5 & 26,7 & 26,6 & 26,9 & 27,3 & 27,8 & 27,3 & 28,1 & 27,9 & 28,2 & AUS' & AUS $^{1}$ & 27,4 \\
\hline & Máxima & 35,9 & 34,3 & 33,6 & 34,2 & 34,1 & 34,9 & 35,0 & 36,6 & 37,1 & 37,4 & AUS' & AUS $^{1}$ & 37,4 \\
\hline
\end{tabular}

${ }^{1}$ AUS: dados Ausentes.

\section{Tabela 2}

Umidades relativas médias (\%) mensais no aeródromo de Eduardo Gomes no período de fevereiro de 2000 a outubro de 2005.

\begin{tabular}{|c|c|c|c|c|c|c|c|c|c|c|c|c|c|}
\hline \multicolumn{10}{|c|}{ UMIDADE RELATIVA MÉDIA SBEG 2000 A 2005} \\
\hline ANO & Jan & Fev & Mar & Abr & Maio & Jun & Jul & Ago & Set & Out & Nov & Dez & TOTAL \\
\hline 2000 & AUS $^{1}$ & 91,7 & AUS $^{1}$ & 92,9 & AUS $^{1}$ & AUS $^{1}$ & AUS $^{1}$ & 84,6 & 85,2 & 87,2 & AUS' & 89,0 & 88,4 \\
\hline 2001 & AUS $^{1}$ & 92,4 & AUS $^{1}$ & 92,4 & 91,6 & 91,6 & 88,3 & 79,1 & 85,7 & 82,2 & 85,0 & 93,2 & 88,1 \\
\hline 2002 & 91,3 & 93,1 & 92,7 & 92,5 & 93,6 & 90,4 & 86,2 & 85,9 & 83,9 & 85,6 & 89,7 & 93,2 & 89,8 \\
\hline 2003 & 88,2 & 90,7 & 92,1 & 92,7 & 93,0 & 91,9 & 87,0 & 87,2 & 87,8 & 88,8 & 89,2 & 91,0 & 90,4 \\
\hline 2004 & AUS $^{1}$ & AUS $^{1}$ & AUS $^{1}$ & AUS $^{1}$ & AUS $^{1}$ & AUS $^{1}$ & AUS $^{1}$ & 77,9 & 78,8 & 78,4 & 77,5 & 80,6 & 79,7 \\
\hline 2005 & 81,0 & 84,3 & 85,0 & 84,9 & 82,1 & 80,3 & 81,3 & 77,0 & 78,6 & 79,7 & AUS $^{1}$ & AUS $^{1}$ & 81,4 \\
\hline
\end{tabular}

${ }_{1}^{1}$ AUS: dados Ausentes. 
Tabela 3

Pressão atmosférica média ao nível da estação $(\mathrm{hPa})$ no aeródromo de Eduardo Gomes no período de fevereiro de 2000 a outubro de 2005.

\begin{tabular}{|c|c|c|c|c|c|c|c|c|c|c|c|c|c|}
\hline \multicolumn{10}{|c|}{ PRESSÃO MÉDIA AO NÍVEL DA ESTAČ̃̃O SBEG 2000 A 2005 } \\
\hline ANO & Jan & Fev & Mar & Abr & Maio & Jun & Jul & Ago & Set & Out & Nov & Dez & TOTAL \\
\hline 2000 & AUS $^{1}$ & 1002,0 & AUS $^{1}$ & 1001,7 & AUS $^{1}$ & AUS $^{1}$ & AUS & 1002,5 & 1001,4 & 1001,3 & AUS $^{1}$ & 1000,8 & 1001,6 \\
\hline 2001 & AUS $^{1}$ & 1001,5 & AUS $^{1}$ & 1002,3 & 1002,3 & 1004,3 & 1003,4 & 1003,8 & 1001,9 & 1000,9 & 1000,2 & 999,8 & 1002,0 \\
\hline 2002 & 1001,7 & 1001,9 & 1001,9 & 1001,4 & 1002,1 & 1003,8 & 1003,5 & 1002,6 & 1001,6 & 1000,3 & 1000,8 & 1001,5 & 1001,9 \\
\hline 2003 & 1001,5 & 1001,4 & 1001,3 & 1002,1 & 1002,4 & 1002,6 & 1003,6 & 1003,5 & 1002,4 & 1000,6 & 1000,0 & 1000,4 & 1001,8 \\
\hline 2004 & 1000,4 & 1001,8 & 1001,2 & 1001,1 & 1002,7 & 1004,1 & 1002,9 & 1003,5 & 1001,8 & 1000,4 & 999,6 & 1000,2 & 1001,6 \\
\hline 2005 & 999,9 & 1000,5 & 1002,1 & 1001,7 & 1001,7 & 1002,4 & 1004,0 & 1002,6 & 1002,0 & 1000,6 & AUS $^{1}$ & AUS $^{1}$ & 1001,8 \\
\hline
\end{tabular}

${ }^{1}$ AUS: dados Ausentes.

\section{Tabela 4}

Precipitação acumulada mensal (mm) no aeródromo de Eduardo Gomes

no período de fevereiro de 2000 a outubro de 2005.

\begin{tabular}{|c|c|c|c|c|c|c|c|c|c|c|c|c|c|}
\hline \multicolumn{14}{|c|}{ PRECIPITAÇÃO ACUMULADA SBEG 2000 A 2005} \\
\hline ANO & Jan & Fev & Mar & Abr & Maio & Jun & Jul & Ago & Set & Out & Nov & Dez & TOTAL \\
\hline 2000 & AUS $^{1}$ & 281,4 & AUS' $^{\prime}$ & 427,7 & AUS $^{1}$ & AUS $^{1}$ & AUS $^{1}$ & 54,6 & 89,6 & 167,3 & AUS' & 95,2 & 1115,8 \\
\hline 2001 & AUS' & 202,9 & AUS $^{1}$ & 204,3 & 186,1 & 154,2 & 39,1 & 16,2 & 99,6 & 253,9 & 73,8 & 134,4 & 1364,5 \\
\hline 2002 & 382,7 & 280,5 & 271,8 & 298,0 & 303,0 & 140,4 & 28,8 & 68,7 & 113,2 & 233,9 & 165,6 & 300,7 & 2587,3 \\
\hline 2003 & 82,5 & 229,5 & 169,5 & 375,9 & 291,5 & 180,2 & 63,6 & 169,5 & 77,1 & 138,5 & 104,4 & 190,6 & 2072,8 \\
\hline 2004 & 293,6 & 215,1 & 472,7 & 354,8 & 282,8 & 124,8 & 103,2 & 89,8 & 127,1 & 210,7 & 195,4 & 195,0 & 2665,0 \\
\hline 2005 & 250,3 & 436,9 & 561,4 & 400,0 & 325,3 & 93,8 & 101,7 & 109,0 & 172,7 & 166,6 & AUS' & AUS ${ }^{\prime}$ & 2617,7 \\
\hline
\end{tabular}

${ }^{1}$ AUS: dados Ausentes.

\section{Tabela 5}

Médias mensais do total de nuvens (oitavos) no aeródromo de Eduardo Gomes no período de fevereiro de 2000 a novembro de 2005.

\begin{tabular}{|c|c|c|c|c|c|c|c|c|c|c|c|c|}
\hline \multicolumn{10}{|c|}{ COBERTURA MÉDIA DE NUVENS SBEG } \\
\hline & Jan & Fev & Mar & Abr & Maio & Jun & Jul & Ago & Set & Out & Nov & Dez \\
\hline 2000 & AUS $^{1}$ & 6 & AUS & 6 & AUS' & AUS' & AUS' & 4 & 5 & 6 & AUS' $^{1}$ & 5 \\
\hline 2001 & 6 & 6 & AUS $^{1}$ & 6 & 6 & 6 & 5 & 4 & 5 & 5 & 5 & 7 \\
\hline 2002 & 6 & 6 & 6 & 6 & 6 & 6 & 4 & 5 & 5 & 6 & 6 & 6 \\
\hline 2003 & 5 & 6 & 6 & 6 & 6 & 5 & 4 & 5 & 5 & 6 & 6 & 6 \\
\hline 2004 & 6 & 6 & 6 & 6 & 6 & 5 & 5 & 4 & 6 & 6 & 6 & 6 \\
\hline 2005 & 5 & 6 & 6 & 6 & 5 & 4 & 4 & 5 & 5 & 5 & 6 & AUS $^{1}$ \\
\hline
\end{tabular}

${ }^{1}$ AUS: dados Ausentes. 